\title{
Complex formation between calcium and hydroxy/oxocarboxylates in neutral and highly alkaline aqueous solutions
}

PhD Dissertation

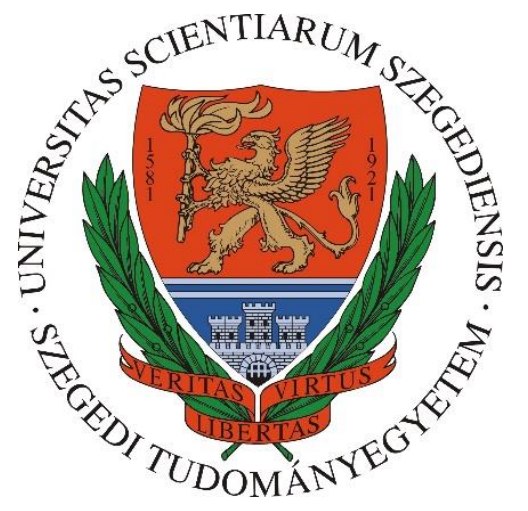

\section{Csilla Dudás}

\author{
Supervisors: $\quad$ Prof. Dr. Pál Sipos \\ Prof. Dr. István Pálinkó
}

Doctoral School of Chemistry

Department of Inorganic and Analytical Chemistry, Faculty of Science and Informatics, University of Szeged

Szeged 


\section{Table of contents}

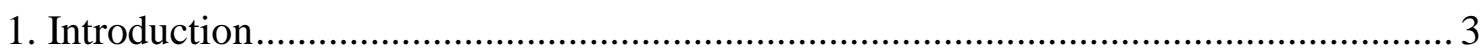

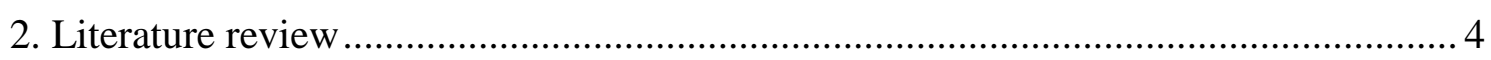

2.1. Properties of hydroxy and oxocarboxylates in aqueous solutions ....................... 4

2.1.1. Acidic and neutral medium ............................................................... 4

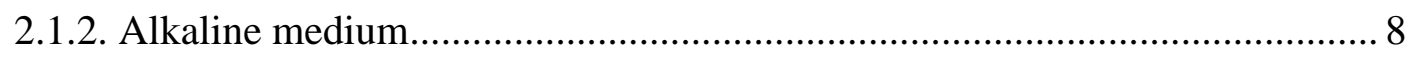

2.2. Calcium complexing properties of hydroxy and oxocarboxylates ...................... 9

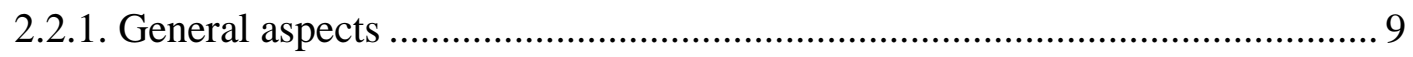

2.2.2. Calcium complexes formed in neutral and acidic medium........................... 9

2.2.2. Calcium complexes formed in highly alkaline medium ............................ 11

3.3. Small molecular ligands in radioactive waste repositories ............................... 12

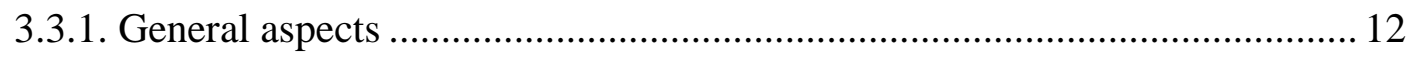

3.3.2. Importance of high $\mathrm{pH}$ and high salt concentration................................. 13

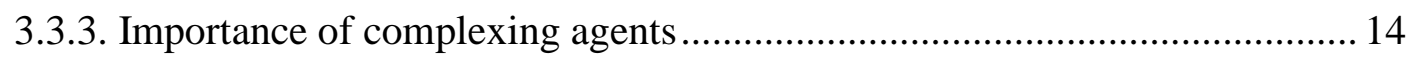

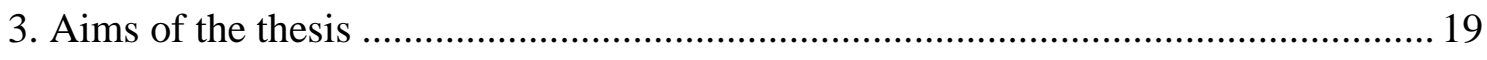

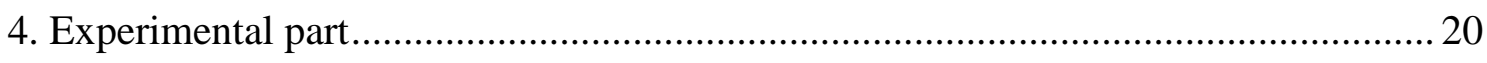

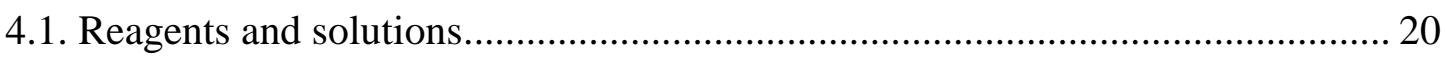

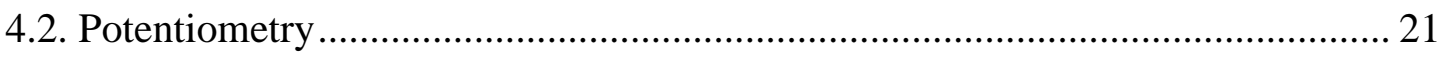

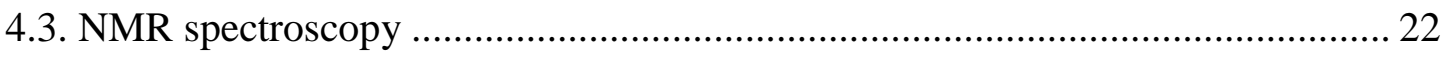

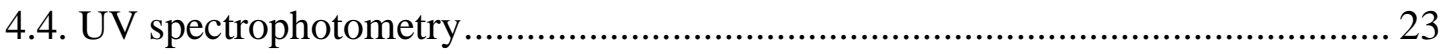

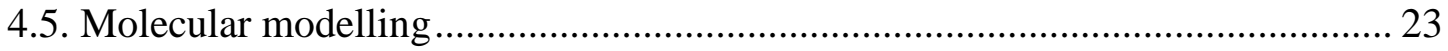

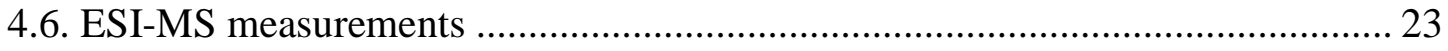

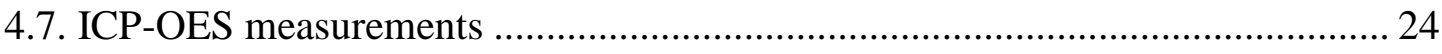

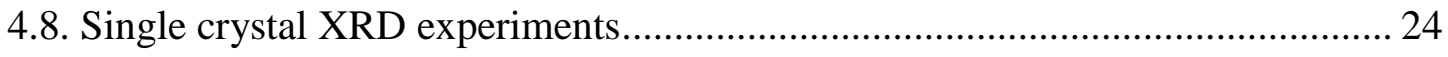

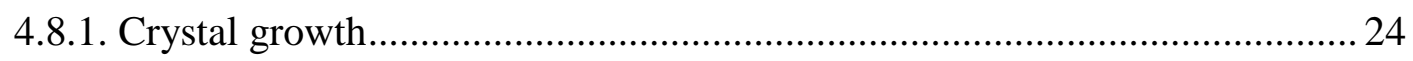

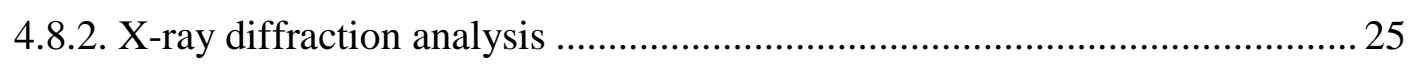

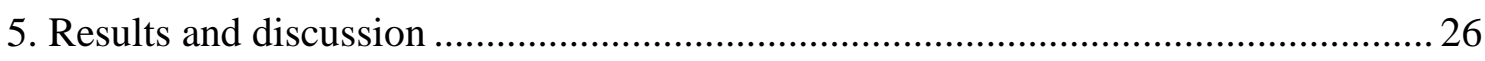


5.1. Comparison of the calcium complexing properties of $\alpha$-D-isosaccharinate and Dgluconate

5.1.1. Complexation of $\mathrm{Ca}^{2+}$ by $\alpha$-D-isosaccharinate in neutral medium.............. 26

5.1.2. Deprotonation of $\alpha$-D-isosaccharinate in alkaline medium ........................ 29

5.1.3. Complexation of $\mathrm{Ca}^{2+}$ by $\alpha$-D-isosaccharinate in alkaline medium 31

5.2. Comparison of the crystal structure of calcium $\alpha$-D-isosaccharinate and calcium D-gluconate. 40

5.2.1. Preparation of calcium $\alpha$-D-isosaccharinate and calcium $D$-gluconate single crystals

5.2.2. Crystal structure of calcium $\alpha$-D-isosaccharinate

5.2.3. Crystal structure of calcium D-gluconate

5.3. Calcium complexing properties of lactate

5.3.1. Complexation of $\mathrm{Ca}^{2+}$ by lactate in neutral medium 50

5.3.2. Deprotonation of lactate in neutral medium 53

5.3.3. Complexation of $\mathrm{Ca}^{2+}$ by lactate in alkaline medium. 55

5.4. Calcium complexing properties of $\alpha$ - and $\beta$-ketoglutarate 60

5.4.1. Complexation of $\mathrm{Ca}^{2+}$ by $\alpha$ - and $\beta$-ketoglutarate in neutral medium 60

5.4.2. Deprotonation of $\alpha$ - and $\beta$-ketoglutarate in alkaline medium 62

5.4.3. Complexation of $\mathrm{Ca}^{2+}$ by $\alpha$ - and $\beta$-ketoglutarate in alkaline medium 67

6. Conclusions 74

7. Összefoglalás 77

8. References 80

9. Acknowledgement 87 


\section{Introduction}

The metal complexes of polyhydroxy carboxylates play important roles in living organisms as well as in several industrial processes. These ligands are considered to be efficient metal chelators due to the presence of both carboxylate and hydroxy groups. In alkaline medium, where deprotonation of an $\mathrm{OH}$ group occurs followed by the subsequent formation of an alcoholate moiety, they become capable of forming more stable complexes.

Low and intermediate level radioactive wastes are usually deposited in underground concrete-based repositories (e.g., in barren salt mines). By the incidental water intrusion and the degradation of cement, the cement pore water is assumed to be hypersalic and hyperalkaline. Under these conditions, the organics (e.g., cellulose) present in the wastes, undergo degradation. The main degradation products of cellulose is $\alpha$-D-isosaccharinate $\left(\mathrm{Isa}^{-}\right)$. Due to its complexing ability towards radioactive nuclides, it may have strong effect on the solubility of actinides and lanthanides. The formation of such Isa-An/Ln complexes may enhance the mobility of the radioactive metal ions (i.e., decrease their sorption on the cement matrix) leading to environmental contamination.

Another relevant organic compound in cementitious environments is D-gluconate $\left(\mathrm{Gluc}^{-}\right)$, which is released from the solid matrix being a cement additive (plasticizer) used during the processing of concrete. Gluc ${ }^{-}$is often considered to be a readily available structural and functional model compound of $\mathrm{Isa}^{-}$, which is not only expensive, when commercially acquired, but also challenging to prepare it in sufficiently pure form.

The presence of calcium (which is originated from Portland cement) may also have influence on the mobility of radionuclides by the formation of ternary, heteropolynuclear $\mathrm{Ca}-\mathrm{An} / \mathrm{Ln}-\mathrm{Isa}$ species.

Calcium is known to be able to induce the deprotonation of polyhydroxy carboxylates in alkaline medium forming high stability, sometimes multinuclear complexes. However, little is known about the effect of $\mathrm{Ca}^{2+}$ on the deprotonation of oxocarboxylates, where the deprotonation occurs on a methylene group instead of a hydroxy group.

In this work, the complex formation between $\mathrm{Ca}^{2+}$ and four small anionic ligands (two hydroxycarboxylates and two oxocarboxylates) were studied both in neutral and alkaline solutions by a series of characterisation techniques. Additionally, the similarities and differences between Isa ${ }^{-}$and Gluc $^{-}$under repository conditions was scrutinized. 


\section{Literature review}

\subsection{Properties of hydroxy and oxocarboxylates in aqueous solutions}

\subsubsection{Acidic and neutral medium}

Hydroxycarboxylic acids are naturally occurring compounds having pronounced influence on the inorganic constituents of soil, water and sediment. Oxocarboxylic acids, especially $\alpha$-keto acids, are biologically important substances being involved $e . g$. in the citric acid cycle as well as in glycolysis. ${ }^{[1]}$

Hydroxy and oxocarboxylic acids are usually weak acids. For the weak acid HA, the deprotonation (acid dissociation) reaction and the corresponding equilibrium constant are

$$
\begin{aligned}
& \mathrm{HA} \rightleftharpoons \mathrm{A}^{-}+\mathrm{H}^{+} \\
& K_{\mathrm{a}}=\frac{\left[\mathrm{A}^{-}\right]\left[\mathrm{H}^{+}\right]}{[\mathrm{HA}] \mathrm{c}^{\ominus}}
\end{aligned}
$$

where $\mathrm{c}^{\ominus}$ is the standard molar concentration, $1 \mathrm{~mol} \cdot \mathrm{dm}^{-3}$.

Concerning $\alpha$-D-isosaccharinic acid (HIsa, Fig. 1. a), a polyhydroxy carboxylate relevant in nuclear waste disposal, the deprotonation constant, $\mathrm{p} K_{a}$ was determined to be between 3.27 and $4.46,{ }^{[2-11]}$ depending on the temperature, ionic strength and experimental technique applied during the measurements. Table 1 summarizes the values obtained for the reaction HIsa $\rightleftharpoons \mathrm{Isa}^{-}+\mathrm{H}^{+}$.

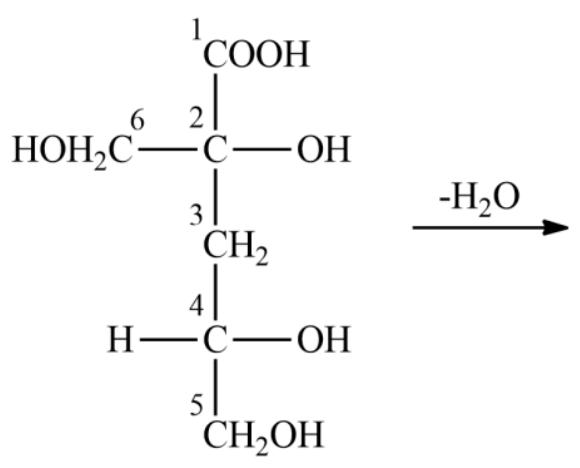

(a)<smiles>O=C1CCC(O)(CO)CC(CO)OC1</smiles>

(b)

Figure 1. Structure of $\alpha$-D-isosaccharinic acid (HIsa, a) and $\alpha$-D-isosaccharino-1,4-lactone $\left(\right.$ Isa $\left._{\mathrm{L}}, \mathrm{b}\right)$.

\footnotetext{
${ }^{1}$ All stability products are defined as dimensionless quantities throughout this work.
} 
In acidic medium, polyhydroxy carboxylic acids partially transform to lactones (cyclic esters). ${ }^{[12]} \mathrm{Up}$ to date, only three studies have reported about the lactonization process of HIsa. ${ }^{[4,6,10]}$ During the lactonization of HIsa, a five-membered $\gamma$-lactone $(\alpha$-Disosaccharino-1,4-lactone, IsaL) is formed (see, Fig. 1). Rai et al. obtained a value of $\log K^{0}=0.37(7)^{2}$ from NMR measurements for the reaction HIsa $\rightleftharpoons \mathrm{Isa}_{\mathrm{L}}+\mathrm{H}_{2} \mathrm{O} \cdot{ }^{[13]}$ Ekberg et al. used ion chromatography to selectively detect Isa- ${ }^{[10]}$ From the equilibrium data, the lactonization constant was found to be $\log K=0.84(4)$ at $\mathrm{I}=0.1 \mathrm{M} \mathrm{NaClO}_{4}$. They also calculated the transformation rates from HIsa to Isa $\mathrm{L}_{\mathrm{L}}$ and from Isa $\mathrm{L}_{\mathrm{L}}$ to HIsa from the ion chromatographic data. The rate constants reported were $\mathrm{k}^{+}=4.85(3) \cdot 10^{-3} \mathrm{~min}^{-1}$ and $\mathrm{k}^{-}=7.35(4) \cdot 10^{-4} \min ^{-1}$ for the forward and backward reactions, respectively. These results show that the lactonization reaction is very slow compared to simple protonation or deprotonation reactions. From these two kinetic constants, an independent value for the lactonization constant was calculated to be $\log K=0.820(5) .{ }^{[14]}$ These data indicate that the conversion between HIsa and Isa $a_{L}$ is relatively slow, while the hydrolysis of the lactone occurs more rapidly. ${ }^{[10]}$ Brown et al. also used ion chromatography to determine the lactonization constant of HIsa at $\mathrm{I}=0.1 \mathrm{M}$ and $1.0 \mathrm{M} \mathrm{NaClO}_{4}$. They found $\log K$ to be $0.80(2)$ and 0.81(4), respectively. The determined equilibrium constants for the lactonization process are summarized in Table 1.

Lactic acid (2-hydroxypropanoic acid, HLac) is a widely investigated hydroxycarboxylic acid relevant in both pharmaceutical, biological and food industries. ${ }^{[15-19]}$ The acid dissociation process of HLac is extensively studied. Depending on the experimental method, temperature and ionic strength applied, the deprotonation constant, $\mathrm{p} K_{a}$, for the reaction $\mathrm{HLac} \rightleftharpoons \mathrm{Lac}^{-}+\mathrm{H}^{+}$ranges from 3.45 to 3.98 determined via capillary zone electrophoresis, ${ }^{[3,7]}$ conductometry, ${ }^{[20]}$ coulometry $^{[22]}$ or potentiometry. ${ }^{[21,23-30]}$ The data determined for the $\mathrm{p} K_{a}$ of HLac are collected in Table 1.

In acidic medium, HLac can be dimerized through a condensation reaction forming a dilactide. After ring opening, this dilactide can be further polymerized to obtain polylactic acid (PLA) (Fig. 2). ${ }^{[1,32]}$ PLA is a biodegradable polymer, which is a highly preferable property from an environmental viewpoint. It is used as a component of drug delivery systems, degradable sutures, and orthopedic supports. Its high strength and thermoplastic properties allow it to be processed in a variety of objects including disposable bags, liners and utensils. ${ }^{[31-33]}$

\footnotetext{
${ }^{2}$ Hereafter, $\pm 3 \mathrm{SE}$ values will be given in parenthesis, e.g. the exact meaning of $\log K=1.00$ (3) is $1.00 \pm 0.03$, where $\mathrm{SE}=0.01$
} 
Table 1. Acid dissociation constants of HIsa and HLac and lactonization constants of HIsa. ( $\pm 3 \mathrm{SE}$ in given in parentheses, where available).

\begin{tabular}{|c|c|c|c|c|c|}
\hline Reaction & Ionic medium & $\mathrm{T}\left({ }^{\circ} \mathrm{C}\right)$ & $\log K$ & Ref. & Method $^{\mathrm{a}}$ \\
\hline \multirow[t]{13}{*}{$\mathrm{HIsa} \rightleftharpoons \mathrm{Isa}^{-}+\mathrm{H}^{+}$} & $\mathrm{I} \rightarrow 0$ & 23 & -4.46 & 2 & SOL \\
\hline & $\mathrm{I} \rightarrow 0$ & 25 & -3.87 & 3 & CZE \\
\hline & $\mathrm{I} \rightarrow 0$ (using NaIsa) & 22 & $-3.27(1)$ & 4,5 & NMR \\
\hline & $\begin{array}{l}\mathrm{I} \rightarrow 0 \text { (using } \\
\left.\mathrm{Ca}(\mathrm{Isa})_{2}\right)\end{array}$ & 22 & $-3.36(2)$ & 4 & NMR \\
\hline & $\mathrm{I} \rightarrow 0$ & 25 & $-4.04(6)^{b}$ & 6 & - \\
\hline & $\mathrm{I}<0.002$ & - & -4.05 & 7 & CZE \\
\hline & 0.002 & - & -4.02 & 8 & CZE \\
\hline & $\mathrm{I}=0.01 \mathrm{M} \mathrm{NaClO}_{4}$ & 25 & -3.83 & 9 & POT \\
\hline & $\mathrm{I}=0.1 \mathrm{M} \mathrm{NaClO} 4$ & 25 & -3.75 & 9 & POT \\
\hline & $\mathrm{I}=1.0 \mathrm{M} \mathrm{NaClO}_{4}$ & 22.8 & $-3.78(5)$ & 10 & POT \\
\hline & $\mathrm{I}=1.0 \mathrm{M} \mathrm{NaClO}_{4}$ & 34.5 & $-3.64(2)$ & 10 & POT \\
\hline & $\mathrm{I}=1.0 \mathrm{M} \mathrm{NaClO}_{4}$ & 44.2 & $-3.53(3)$ & 10 & POT \\
\hline & $\mathrm{I}=1.0 \mathrm{M} \mathrm{NaClO} 4$ & 25 & $-3.65(5)$ & 11 & POT \\
\hline \multirow[t]{5}{*}{$\mathrm{HIsa} \rightleftharpoons \mathrm{Isa}_{\mathrm{L}}+\mathrm{H}_{2} \mathrm{O}$} & $\mathrm{I} \rightarrow 0$ & 25 & $0.37(7)$ & 13 & NMR \\
\hline & $\mathrm{I}=0.1 \mathrm{M} \mathrm{NaClO}_{4}$ & 23 & $0.84(4)$ & 10 & CHR \\
\hline & & & $0.820(5)$ & 10 & CHR \\
\hline & $\mathrm{I}=0.1 \mathrm{M} \mathrm{NaClO}_{4}$ & 23 & $0.80(2)$ & 6 & CHR \\
\hline & $\mathrm{I}=1.0 \mathrm{M} \mathrm{NaClO}_{4}$ & 23 & $0.81(4)$ & 6 & CHR \\
\hline \multirow[t]{13}{*}{$\mathrm{HLac} \rightleftharpoons \mathrm{Lac}^{-}+\mathrm{H}^{+}$} & $\mathrm{I} \rightarrow 0$ & 25 & -3.858 & 20 & $\mathrm{CON}$ \\
\hline & $\mathrm{I} \rightarrow 0$ & 25 & -3.84 & 3 & CZE \\
\hline & $\mathrm{I}<0.002$ & - & -3.98 & 7 & CZE \\
\hline & $\mathrm{I}=0.1 \mathrm{M} \mathrm{NaCl}$ & 25 & -3.80 & 21 & POT \\
\hline & $\mathrm{I}=0.15 \mathrm{M} \mathrm{NaCl}$ & 25 & -3.51 & 22 & $\mathrm{COU}$ \\
\hline & $\mathrm{I}=0.15 \mathrm{M} \mathrm{NaCl}$ & 37 & -3.70 & 22 & $\mathrm{COU}$ \\
\hline & $\mathrm{I}=0.2 \mathrm{M} \mathrm{KCl}$ & 20 & -3.739 & 23 & $\mathrm{POT}-\mathrm{H}_{2} / \mathrm{Pt}$ \\
\hline & $\mathrm{I}=0.5 \mathrm{M} \mathrm{NaClO}_{4}$ & 25 & $-3.45(3)$ & 24 & POT \\
\hline & $\mathrm{I}=0.6 \mathrm{M} \mathrm{NaCl}$ & 25 & -3.572 & 25 & POT \\
\hline & $\mathrm{I}=1.0 \mathrm{M} \mathrm{NaCl}$ & 25 & $-3.597(5)$ & 26 & POT \\
\hline & $\mathrm{I}=1.0 \mathrm{M} \mathrm{NaClO}_{4}$ & 25 & -3.63 & 27 & POT \\
\hline & $\mathrm{I}=1.0 \mathrm{M} \mathrm{NaClO}_{4}$ & 20 & -3.626 & 28 & POT \\
\hline & $\mathrm{I}=2.0 \mathrm{M} \mathrm{NaClO}_{4}$ & 25 & -3.80 & 29 & POT \\
\hline
\end{tabular}

${ }^{a} \mathrm{SOL}=$ solubility, $\mathrm{CZE}=$ capillary zone electrophoresis, NMR = nuclear magnetic resonance spectroscopy, POT = potentiometry using glass electrode, $\mathrm{POT}-\mathrm{H}_{2} / \mathrm{Pt}=$ potentiometry using hydrogen electrode, $\mathrm{CHR}=$ ion chromatography, $\mathrm{COU}=$ coulometry, $\mathrm{CON}=$ conductometry

${ }^{b}$ Data re-evaluated from previous literature data 


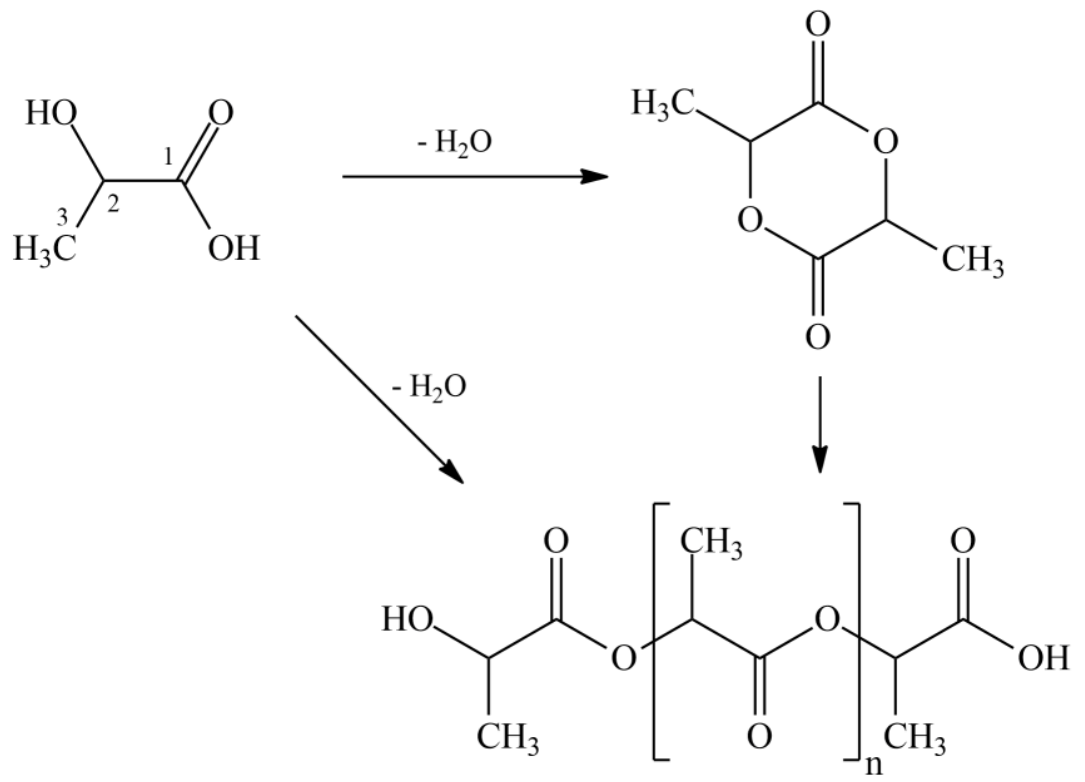

Figure 2. Structures of lactic acid (HLac), its cyclic dimer (lactide) and polylactic acid (PLA).

Among oxocarboxylic acids, $\alpha$-ketoglutaric acid (2-oxopentanedioic acid, $\mathrm{H}_{2}(\alpha-\mathrm{Ket})$, Fig. 3. a) is an important metabolite and substrate of several enzymatic reactions. ${ }^{[34-36]}$ The two carboxylic groups of $\mathrm{H}_{2}(\alpha-\mathrm{Ket})$ act as weak acids in water. From potentiometric measurements, the $\mathrm{p} K_{a}$ of the first $\left(\mathrm{p} K_{1}\right)$ and second $\left(\mathrm{p} K_{2}\right)$ deprotonations were determined to be 2.8 and $4.8(\mathrm{I}=0.1 \mathrm{M})^{[37]}$ as well as 2.00 and 4.60 (ionic stength was not reported $)^{[38]}$ for the reactions $\mathrm{H}_{2}(\alpha-\mathrm{Ket}) \rightleftharpoons \mathrm{H}(\alpha-\mathrm{Ket})^{-}+\mathrm{H}^{+}$and $\mathrm{H}(\alpha-\mathrm{Ket})^{-} \rightleftharpoons$ $\alpha-\mathrm{Ket}^{2-}+\mathrm{H}^{+}$, respectively. ${ }^{1} \mathrm{H}$ NMR measurements showed that in highly acidic medium $(\mathrm{pH}=0.5) \mathrm{H}_{2}(\alpha-\mathrm{Ket})$ existed as an equilibrium mixture of the cyclic hemiketal $(16 \%)$, geminal diol (53\%) and keto (31\%) forms (see Fig. 3). ${ }^{[39,40]}{ }^{13} \mathrm{C} \mathrm{NMR}$ spectroscopic and UV spectrophotometric measurements yielded somewhat different distribution among the various species (30\% cyclic hemiketal, $35 \%$ geminal diol and $25 \%$ keto forms). ${ }^{[34]}$ However, it was shown that in neutral (or close-to-neutral) solutions, $\alpha-$ Ket $^{2-}$ existed predominantly as the keto form with about $7 \%$ geminal diol. ${ }^{[34,39]}$

$\beta$-Ketoglutaric acid (3-oxopentanedioic acid, $\mathrm{H}_{2}(\beta$-Ket), Fig. 3. b) or most importantly, its derivatives are important starting materials in various organic reactions. ${ }^{[41,42]} \mathrm{H}_{2}(\beta-$ Ket $)$ can also be used in polymerization reactions as water soluble photoinitiator. ${ }^{[43]} \beta-\mathrm{Ket}^{2-}$ was shown to be one of the abiotic oxidation products of citrate released into manganese-rich soils by plants, bacteria and fungi. ${ }^{[4]}$ The acid-base properties of $\beta-\mathrm{Ket}^{2-}$ are rather poorly described, no literature data is available on the acidic dissociation of $\mathrm{H}_{2}(\beta-\mathrm{Ket})$. 
<smiles>O=C(O)CCC(=O)C(=O)O</smiles>

(a)<smiles>O=C(O)CCC(=O)CCC(=O)O</smiles>

(b)

Figure 3. The structures of $\alpha$-ketoglutaric acid $\left(\mathrm{H}_{2}(\alpha-\mathrm{Ket})\right.$, a) with its possible forms in acidic medium, and $\beta$-ketoglutaric acid $\left(\mathrm{H}_{2}(\beta-\mathrm{Ket}), \mathrm{b}\right)$.

\subsubsection{Alkaline medium}

Alcohols are known to be very weak acids in water, with $\mathrm{p} K_{a}$ values generally in the range of $15-20 .{ }^{[45]}$ For instance, the acid dissociation constant, $\mathrm{p} K_{a}$ of methanol and ethanol is 15.5 and 16.0, respectively. ${ }^{[45]}$ Polyhydroxy carboxylates are expected to be stronger acids, since additional $\mathrm{OH}$ groups decrease the $\mathrm{p} K_{a}$ for statistical reasons. ${ }^{[46]}$ For a hydroxycarboxylate anion $\mathrm{A}^{-}$, the alkaline deprotonation reaction and the corresponding equilibrium constant is defined as

$$
\begin{aligned}
& \mathrm{A}^{-} \rightleftharpoons \mathrm{AH}_{-1}^{2-}+\mathrm{H}^{+} \\
& K_{a}=\frac{\left[\mathrm{AH}_{-1}^{2-}\right]\left[\mathrm{H}^{+}\right]}{\left[\mathrm{A}^{-}\right] \mathrm{c}^{\ominus}}
\end{aligned}
$$

where $\mathrm{c}^{\Theta}$ is the standard molar concentration, $1 \mathrm{~mol} \mathrm{dm}^{-3}$. Up to date, no literature data has been reported with regard to the deprotonation of neither Isa ${ }^{-}$nor $\mathrm{Lac}^{-}$. Concerning the estimation that an additional $\mathrm{OH}$ group increases the acidity of an acid, i.e., decreases the $\mathrm{p} K_{a}$ by 0.90 units, ${ }^{[46]}$ the $\mathrm{p} K_{a}$ value of Isa ${ }^{-}$is expected to be around 14.6, given that it contains one $\mathrm{OH}$ group less than D-gluconate (Gluc ${ }^{-}$, Fig. 4), the $\mathrm{p} K_{a}$ of which was determined to be 13.68 at $\mathrm{I}=1.0 \mathrm{M}$ and $\mathrm{T}=25^{\circ} \mathrm{C} \cdot{ }^{[47]}$

Oxocarboxylates can also be deprotonated at high $\mathrm{pH}$. The behaviour of $\alpha-\mathrm{Ket}^{2-}$ in alkaline solutions was examined by Kozlowski et. al. ${ }^{[48]}$ It was shown that upon increasing the $\mathrm{pH}$ of a solution containing $\alpha-\mathrm{Ket}^{2-}$, its methylene group adjacent to the $\mathrm{C}=\mathrm{O}$ group $(\mathrm{C} 3$, that is $)$ underwent<smiles>O=C([O-])[C@H](O)[C@H](O)[C@H](O)[C@H](O)CO</smiles>

Figure 4. Structure of D-gluconate (Gluc ${ }^{-}$. 
deprotonation resulting in the formation of the enolate ion (depicted as two resonance forms in Fig. 5). It was also demonstrated that a new peak appeared on the UV spectrum corresponding to the absorption of the enolate ion at $263 \mathrm{~nm}$. Evaluating the spectral changes, the deprotonation constant of $\alpha-\mathrm{Ket}^{2-}$ was found to be $\mathrm{p} K_{\mathrm{a}}=15.8$ (the ionic strength was not held constant) for the reaction $\alpha-\mathrm{Ket}^{2-} \rightleftharpoons(\alpha-\mathrm{Ket}) \mathrm{H}_{-1}{ }^{3-}+\mathrm{H}^{+}$with $\varepsilon=4800 \mathrm{M}^{-1} \mathrm{~cm}^{-1}$ molar absorbance for the deprotonated species at $263 \mathrm{~nm} .{ }^{[48]}$ The deprotonation of $\beta-\mathrm{Ket}^{2-}$ has not been studied previously.

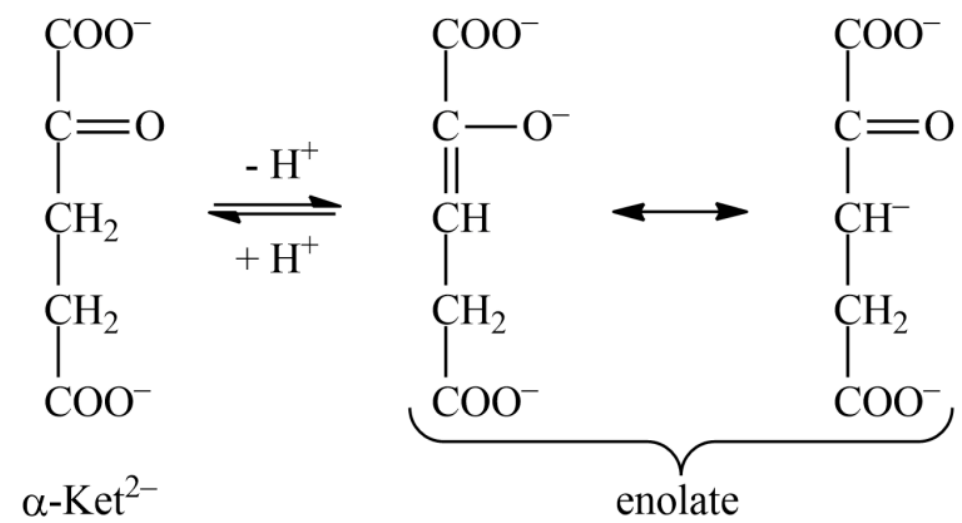

Figure 5. The deprotonation of $\alpha$-ketoglutarate $\left(\alpha-\mathrm{Ket}^{2-}\right)$ : the structure of the resonance forms of $(\alpha-\mathrm{Ket}) \mathrm{H}_{-1}{ }^{3-}$.

\subsection{Calcium complexing properties of hydroxy and oxocarboxylates}

\subsubsection{General aspects}

Carbohydrates and their derivatives generally form weak complexes with $\mathrm{Ca}^{2+}$ in neutral and acidic medium owing to the low electron densities on the oxygen donor atoms in the hydroxy and oxo groups resulting in the reluctant substitution of the water molecules bound in the first coordination sphere of the metal ions. Thus, strong complex formation can only be expected in strongly alkaline solutions after the deprotonation of, e.g., one $\mathrm{OH}$ group of the ligand. ${ }^{[49]}$

\subsubsection{Calcium complexes formed in neutral and acidic medium}

The complex formation between $\mathrm{Ca}^{2+}$ and $\mathrm{Isa}^{-}$in neutral or acidic medium has been studied via solubility measurements, ion-exchange experiments and potentiometry using calcium ion selective electrode (Ca-ISE). ${ }^{[13,50]}$ The association reaction and the corresponding stability product is defined as 


$$
\begin{gathered}
\mathrm{Ca}^{2+}+\mathrm{Isa}^{-} \rightleftharpoons \mathrm{CaIsa}^{+} \\
\beta_{1,1}=\frac{\left[\mathrm{CaIsa}^{+}\right] \mathrm{c}^{\Theta}}{\left[\mathrm{Ca}^{2+}\right]\left[\mathrm{Isa}^{-}\right]}
\end{gathered}
$$

where $\mathrm{c}^{\ominus}$ is the standard molar concentration, $1 \mathrm{~mol} \mathrm{dm}^{-3}$. From solubility measurements, $\log \beta_{1,1}$ was found to be $1.44(7)$ at $\mathrm{T}=23{ }^{\circ} \mathrm{C}$ and $\mathrm{I}=0 \mathrm{M}$ ionic strength. ${ }^{[13]}$ Ion-exchange measurements yielded $\log \beta_{1,1}=1.29(2)$ at $\mathrm{T}=22{ }^{\circ} \mathrm{C}$ and $\mathrm{I}=0.2 \mathrm{M}$ ionic strength, while $\mathrm{Ca}$-ISE potentiometric measurements resulted in a $\log \beta_{1,1}=1.25(4)$ value under the same experimental conditions. ${ }^{[50]}$ In the same work, the $\mathrm{CaIsa}^{+}$species was suggested to be an ion pair, in which $\mathrm{Isa}^{-}$was bound to $\mathrm{Ca}^{2+}$ only through the carboxylate group.

In neutral or acidic solutions containing both $\mathrm{Ca}^{2+}$ and $\mathrm{Lac}^{-}$, the formation of the $\mathrm{CaLac}^{+}$complex has been detected with the formation constant, $\log \beta_{1,1}$ ranging between 0.48 and 1.47 (values measured at the $0-1 \mathrm{M}$ ionic strength range). ${ }^{[22,23,30,53,54,56-58]}$ In two papers, however, the formation of the charge neutral $\mathrm{CaLac}_{2}{ }^{0}$ complex was also reported. ${ }^{[53,54]}$ In these works, the formation constants of the two complexes were determined to be $\log \beta_{1,1}=0.90, \log \beta_{1,2}=1.24$ at $\mathrm{I}=1.0 \mathrm{M}^{[53]}$ and $\log \beta_{1,1}=0.92$, $\log \beta_{1,2}=1.62$ at $\mathrm{I}=0.5 \mathrm{M} \cdot^{[54]}$ The binding sites of $\mathrm{Lac}^{-}$in the $\mathrm{CaLac}^{+}$complex have also been determined by ${ }^{13} \mathrm{C}$ NMR spectroscopic measurements. $\mathrm{Lac}^{-}$was found to act as a bidentate ligand binding $\mathrm{Ca}^{2+}$ through both the carboxylate and the hydroxyl groups. ${ }^{[55]}$

Concerning $\alpha-\mathrm{Ket}^{2-}$, to date, only Schubert et al. reported on the complex formation between calcium and $\alpha-\mathrm{Ket}^{2-}$ in neutral medium. ${ }^{[52]}$ In the presence of $\alpha-\mathrm{Ket}^{2-}$, the neutral $\mathrm{Ca}(\alpha-\mathrm{Ket})^{0}$ species was found to be formed. Its formation constant, $\log \beta_{1,1}$, was determined to be $1.29(\mathrm{I}=0.16 \mathrm{M})$ via ion-exchange measurements. The calcium complexation of $\beta-\mathrm{Ket}^{2-}$ has not been studied previously.

The formation constants of the calcium complexes of both $\mathrm{Isa}^{-}, \mathrm{Lac}^{-}$and $\alpha-\mathrm{Ket}^{2-}$ are summarized in Table 2. 
Table 2. Formation constants of the calcium complexes of $\mathrm{Isa}^{-}, \mathrm{Lac}^{-}$and $\alpha-\mathrm{Ket}^{2-}( \pm 3 \mathrm{SE}$ in given in parentheses, where available).

\begin{tabular}{|c|c|c|c|c|c|}
\hline Reaction & Ionic medium & $\mathrm{T}\left({ }^{\circ} \mathrm{C}\right)$ & $\log \beta$ & Ref. & Method $^{\mathrm{a}}$ \\
\hline \multirow[t]{3}{*}{$\mathrm{Ca}^{2+}+\mathrm{Isa}^{-} \rightleftharpoons \mathrm{CaIsa}^{+}$} & $\mathrm{I} \rightarrow 0$ & 23 & $1.44(7)$ & 13 & SOL \\
\hline & $\mathrm{I} \rightarrow 0$ & 22 & $1.29(2)$ & 50 & IEX \\
\hline & $\mathrm{I} \rightarrow 0$ & 22 & $1.25(4)$ & 50 & POT-ISE \\
\hline \multirow[t]{7}{*}{$\mathrm{Ca}^{2+}+\mathrm{Lac}^{-} \rightleftharpoons \mathrm{CaLac}^{+}$} & $\mathrm{I} \rightarrow 0$ & 25 & 1.47 & 56 & $\mathrm{SOL}$ \\
\hline & $\mathrm{I}=0.15 \mathrm{M} \mathrm{NaCl}$ & 25 & 0.48 & 22 & $\mathrm{COU}$ \\
\hline & $\mathrm{I}=0.2 \mathrm{M} \mathrm{KCl}$ & 25 & 1.07 & 23 & $\mathrm{POT}-\mathrm{H}_{2} / \mathrm{Pt}$ \\
\hline & $\mathrm{I}=0.2-0.8 \mathrm{M}$ & 25 & 1.23 & 57 & SOL \\
\hline & $\mathrm{I}=0.5 \mathrm{M} \mathrm{NaCl}$ & 25 & 0.92 & 54 & POT-ISE \\
\hline & $\mathrm{I}=1.0 \mathrm{M} \mathrm{NaClO}_{4}$ & 25 & 0.90 & 53 & POT-QH \\
\hline & $\mathrm{I}=1.0 \mathrm{M} \mathrm{NaClO}_{4}$ & 25 & 0.91 & 58 & IEX \\
\hline \multirow[t]{2}{*}{$\mathrm{Ca}^{2+}+2 \mathrm{Lac}^{-} \rightleftharpoons \mathrm{CaLac}_{0}{ }^{0}$} & $\mathrm{I}=0.5 \mathrm{M} \mathrm{NaCl}$ & 25 & 1.62 & 54 & POT-ISE \\
\hline & $\mathrm{I}=1.0 \mathrm{M} \mathrm{NaClO}_{4}$ & 25 & 1.24 & 53 & POT-QH \\
\hline $\mathrm{Ca}^{2+}+\alpha-\mathrm{Ket}^{2-} \rightleftharpoons \mathrm{Ca}(\alpha-\mathrm{Ket})^{0}$ & $\mathrm{I}=0.16 \mathrm{M}$ & 25 & 1.29 & 52 & IEX \\
\hline
\end{tabular}

${ }^{a}$ SOL $=$ solubility, IEX $=$ ion exchange measurements, POT-ISE $=$ potentiometry using calcium ion selective electrode, $\mathrm{POT}-\mathrm{H}_{2} / \mathrm{Pt}=$ potentiometry using hydrogen electrode, $\mathrm{POT}-\mathrm{QH}=$ potentiometry using quinhydrone electrode, $\mathrm{COU}=$ coulometry

\subsubsection{Calcium complexes formed in highly alkaline medium}

In strongly alkaline solutions, by the deprotonation of an $\mathrm{OH}$ group and the subsequent formation of an $\mathrm{O}^{-}$moiety, hydroxycarboxylates become stronger complexants, as $\mathrm{O}^{-}$is a more effective binding site due to it increased basicity. On the other hand, $\mathrm{Ca}^{2+}$ ion promotes the deprotonation of the $\mathrm{OH}$ groups and the parallel complex formation, i.e. it decreases the $\mathrm{p} K_{a}$ of the ligand, since it is a strong competitor of $\mathrm{H}^{+}$for the alcoholate moiety. This process is the so-called metal ion promoted deprotonation. ${ }^{[59]}$ As a result, the thus forming complexes have considerably higher stability than the species formed in neutral or acidic medium.

For $\mathrm{Isa}^{-}$, up to date only one publication and a $\mathrm{PhD}$ thesis reported about the formation of a deprotonated calcium complex. ${ }^{[60-61]}$ From solubility measurements, the presence of the $\mathrm{CaIsaH}_{-1}{ }^{0}$ complex was depicted above $\mathrm{pH}=12$. The stability product, $\log \beta_{1,1,-1}$, was determined to be $-10.40(2)$ for the reaction $\mathrm{Ca}^{2+}+\mathrm{Isa}^{-} \rightleftharpoons \mathrm{CaIsaH}_{-1}{ }^{0}+\mathrm{H}^{+}$ at $\mathrm{I}=0 \mathrm{M}$. The general complexation reaction and the corresponding stability product, $\beta_{p, q,-r}$, can be defined as

$$
\mathrm{p} \mathrm{Ca}^{2+}+\mathrm{q} \mathrm{L}^{\mathrm{n}-} \rightleftharpoons \mathrm{Ca}_{\mathrm{p}} \mathrm{L}_{\mathrm{q}} \mathrm{H}_{-\mathrm{r}}^{(2 \mathrm{p}-\mathrm{q}-\mathrm{r})^{+}}+\mathrm{r} \mathrm{H}^{+}
$$




$$
\beta_{p, q,-r}=\frac{\left[\mathrm{Ca}_{p} \mathrm{~L}_{\mathrm{q}} \mathrm{H}_{-\mathrm{r}}^{(2 \mathrm{p}-\mathrm{n} \cdot \mathrm{q}-\mathrm{r})+}\right]\left[\mathrm{H}^{+}\right]^{\mathrm{r}}}{\left[\mathrm{Ca}^{2+}\right]^{\mathrm{p}}\left[\mathrm{L}^{\mathrm{n}-}\right]^{\mathrm{q}} \mathrm{c}^{\mathrm{\theta}^{1-p-q+\mathrm{r}}}}
$$

where $\mathrm{L}^{\mathrm{n}-}$ is any ligand with ' $-\mathrm{n}$ ' charge and $c^{\ominus}$ is the standard molar concentration, $1 \mathrm{~mol} \mathrm{dm}^{-3}$. Accordingly, for Isa ${ }^{-}, \beta_{1,1,-1}$ is defined as

$$
\beta_{1,1,-1}=\frac{\left[\mathrm{CaIsaH}_{-1}{ }^{0}\right]\left[\mathrm{H}^{+}\right]}{\left[\mathrm{Ca}^{2+}\right]\left[\mathrm{Isa}^{-}\right]}
$$

The structurally similar Gluc ${ }^{-}$was also shown to form $\mathrm{CaGlucH}_{-1}{ }^{0}$ complex (with $\left.\log \beta_{1,1,-1}=-10.92(1)\right)$ at $\mathrm{T}=25^{\circ} \mathrm{C}$ and $\mathrm{I}=1.0 \mathrm{M}(\mathrm{NaCl})$, however, this complex was found to be a minor species above $\mathrm{pH}=12$. The predominant species were shown to be the charge neutral $\mathrm{Ca}_{2} \mathrm{GlucH}_{-3}{ }^{0}$ and $\mathrm{Ca}_{3} \mathrm{Gluc}_{2} \mathrm{H}_{-4}{ }^{0}$ complexes with $\log \beta_{2,1,-3}=-33.24$ and $\log \beta_{3,2,-4}=-42.60$, respectively. ${ }^{[47]}$ Similar multinuclear complex formation was reported for D-gulonate $\left(\mathrm{Gul}^{-}\right)^{[62]}$ and D-heptagluconate $\left(\mathrm{Hpgl}^{-}\right){ }^{[63]}$ where the presence of the $\mathrm{Ca}_{3} \mathrm{Gul}_{2} \mathrm{H}_{-3}{ }^{+}\left(\log \beta_{3,2,-3}=-30.46\right), \mathrm{Ca}_{3} \mathrm{Gul}_{2} \mathrm{H}_{-4}{ }^{0}\left(\log \beta_{3,2,-4}=-42.66\right)$ and $\mathrm{Ca}_{3} \mathrm{Hpgl}_{2} \mathrm{H}_{-4}$ $\left(\log \beta_{3,2,-4}=-41.64\right)$ species was shown. The binding sites of the ligand in these multinuclear complexes were scrutinized by Kutus et al. and were suggested to be configuration dependent. ${ }^{[62]}$ Beside the carboxylate moiety, the $\mathrm{C} 2-\mathrm{OH}$ group was found to be the binding site for all three ligands. The additional binding site is the $\mathrm{C} 4-\mathrm{OH}$ group for $\mathrm{Gul}^{-} / \mathrm{Hpgl}^{-}$and the $\mathrm{C} 3-\mathrm{OH}$ group for $\mathrm{Gluc}^{-}$. These findings highlight the importance of the relative configuration of these polyhydroxy carboxylates. Accordingly, the erythro $\left(\mathrm{Gul}^{-}\right.$and $\left.\mathrm{Hpgl}^{-}\right)$or the threo $\left(\mathrm{Gluc}^{-}\right)$arrangement determines whether the $\mathrm{C} 3-\mathrm{OH}$ or the C4-OH group acts as a binding site.

To the best of our knowledge, no literature data have been reported with regard to the calcium complexation of $\mathrm{Lac}^{-}, \alpha-\mathrm{Ket}^{2-}$ or $\beta-\mathrm{Ket}^{2-}$ in alkaline medium to date.

\subsection{Small molecular ligands in radioactive waste repositories}

\subsubsection{General aspects}

The safe storage of radioactive waste arising mainly from the operation of nuclear power plants is a long standing and as yet unresolved problem. For low and intermediate level radioactive wastes (L/ILW), a cement matrix is frequently used to solidify the waste components. The L/IL wastes stabilized in cement are then disposed in deep geological 
repositories (e.g., underground salt mines). However, the long term containment of radioactive waste within cement containers and repositories is problematic.

\subsubsection{Importance of high $\mathrm{pH}$ and high salt concentration}

Portland cement, used as a solidification, backfill and construction material, is considered to determine the chemistry of a L/ILW repository for very long periods of time. ${ }^{[64,65]}$ Intrusion of water to the repositories is assumed to yield strongly saline, $\mathrm{MgCl}_{2}$ - or NaCl-dominated brines. ${ }^{[66]}$ Upon contact with chloride-rich brines, the cement is supposed to degrade. The composition of the brine as well as the cement to brine ratio $(\mathrm{m} / \mathrm{V})$ have a strong influence on the $\mathrm{pH}$ of the cement pore water $(\mathrm{CPW})$. For $\mathrm{MgCl}_{2}$ dominated brines, at lower $\mathrm{m} / \mathrm{V}$ ratios, the CPW is predominated by $\mathrm{MgCl}_{2}$, and the solution is weakly alkaline. However, at higher $\mathrm{m} / \mathrm{V}$ ratios, the $\mathrm{CPW}$ is rich in $\mathrm{CaCl}_{2}$ due to the reaction between $\mathrm{Ca}(\mathrm{OH})_{2}$ (present in the cement) and $\mathrm{MgCl}_{2}$. This process increases the $\mathrm{pH}$ of the $\mathrm{CPW}$ up to $12-12.5$, which was shown to remain this high even after 22 years. ${ }^{[67]}$ In these systems, the total concentration of $\mathrm{Ca}^{2+}$ varies between $2-20$ $\mathrm{mM}$. For $\mathrm{NaCl}$ brines, the $\mathrm{pH}$ can increase up to $13.3 .{ }^{[65,67,68]}$ In these experiments, initially, the model brine contained 4.3 molal (m) $\mathrm{Mg}^{2+}$ or $6.1 \mathrm{~m} \mathrm{Na}^{+}$for the $\mathrm{MgCl}_{2}$ and $\mathrm{NaCl}$ systems, respectively. ${ }^{[67,68]}$

In principle, the highly caustic medium of the CPW should cause the adsorption and precipitation of radionuclides thus suppressing their mobility as well as their release to the geosphere. ${ }^{[69-74]}$ However, from several solubility, EXAFS (Extended X-ray Absorption Fine Structure) and TRLFS (Time-Resolved Laser-induced Fluorescence Spectroscopy) studies, it was found that in the presence of calcium, ternary $\mathrm{Ca}-\mathrm{M}(\mathrm{IV} / \mathrm{III})-\mathrm{OH}$ complexes were formed. ${ }^{[66,75-77]}$ Among others, the formation of complexes such as $\mathrm{Ca}_{2}\left[\mathrm{Zr}(\mathrm{OH})_{6}\right]^{2+}, \quad \mathrm{Ca}_{3}\left[\mathrm{Zr}(\mathrm{OH})_{6}\right]^{4+}, \quad \mathrm{Ca}_{4}\left[\mathrm{Th}(\mathrm{OH})_{8}\right]^{4+},{ }^{[75,76]}$ $\mathrm{Ca}_{4}\left[\mathrm{Pu}(\mathrm{OH})_{8}\right]^{2+}, \quad \mathrm{Ca}_{4}\left[\mathrm{~Np}(\mathrm{OH})_{8}\right]^{4+},{ }^{[77]} \quad \mathrm{Ca}\left[\mathrm{Cm}(\mathrm{OH})_{3}\right]^{2+}, \quad \mathrm{Ca}_{2}\left[\mathrm{Cm}(\mathrm{OH})_{4}\right]^{3+}$, $\mathrm{Ca}_{3}\left[\mathrm{Cm}(\mathrm{OH})_{6}\right]^{3+}, \mathrm{Ca}\left[\mathrm{Nd}(\mathrm{OH})_{3}\right]^{2+}, \mathrm{Ca}_{2}\left[\mathrm{Nd}(\mathrm{OH})_{4}\right]^{3+}$ and $\mathrm{Ca}_{3}\left[\mathrm{Nd}(\mathrm{OH})_{6}\right]^{3+}{ }^{[66]}$ has been reported. The presence of $\mathrm{Np}(\mathrm{V})$-containing ternary complexes was also shown. ${ }^{[78-80]}$ It was also demonstrated that in concentrated weakly alkaline $\mathrm{MgCl}_{2}-\mathrm{Mg}\left(\mathrm{NO}_{3}\right)_{2}$ solutions $\mathrm{Mg}\left[\mathrm{M}(\mathrm{III}) \mathrm{NO}_{3} \mathrm{OH}\right]^{3+}$ and $\mathrm{Mg}\left[\mathrm{M}(\mathrm{III}) \mathrm{NO}_{3}(\mathrm{OH})_{2}\right]^{2+}$ complexes $(\mathrm{M}=\mathrm{Cm}, \mathrm{Nd})$ were present. ${ }^{[81]}$ The formation of complexes like these may significantly increase the total concentration of actinides/lanthanides in the cement pore solution (by several orders of 
magnitude, see Fig. 6), thus reducing their sorption and immobilization leading to environmental contamination.

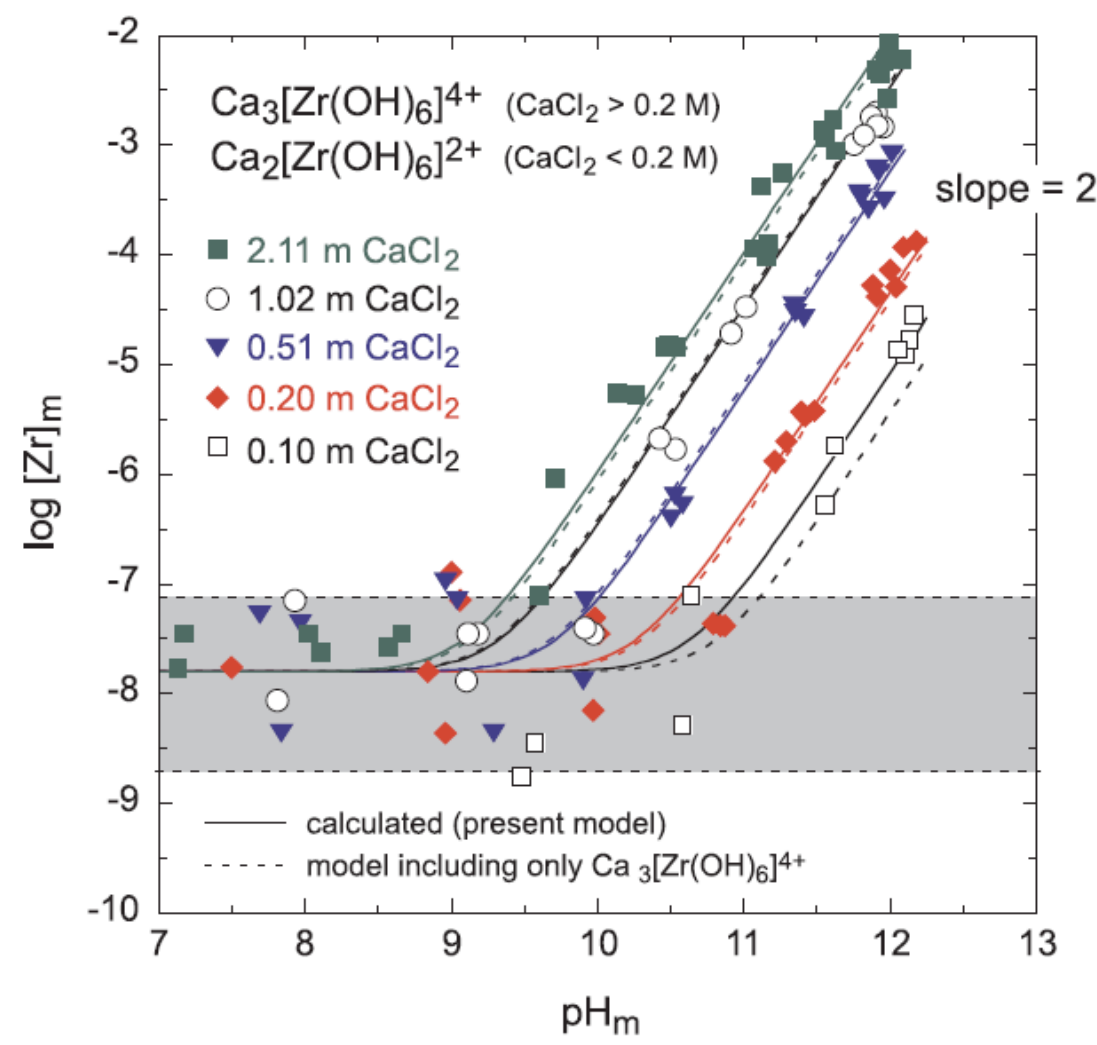

Figure 6. Solubility of $\mathrm{ZrO}_{2} \cdot \mathrm{xH}_{2} \mathrm{O}(\mathrm{s})$ in alkaline $\mathrm{CaCl}_{2}$ solutions. The solid lines are calculated including both $\mathrm{Ca}_{2}\left[\mathrm{Zr}(\mathrm{OH})_{6}\right]^{2+}$ and $\mathrm{Ca}_{3}\left[\mathrm{Zr}(\mathrm{OH})_{6}\right]^{4+}$. The dashed lines are based on a model including only the complex $\mathrm{Ca}_{3}\left[\mathrm{Zr}(\mathrm{OH})_{6}\right]^{4+}$. This figure was taken from Ref. 76 .

\subsubsection{Importance of complexing agents}

Small molecular organic ligands are able to form complexes with radionuclides, which may reduce the sorption and immobilization of lanthanides and actinides by increasing their mobilities leading to the contamination of the environment near the repositories. ${ }^{[82-84]} \mathrm{L} / \mathrm{IL}$ wastes contain substantial amount of cellulosic materials originating from e.g. cotton, paper products, wood. In Switzerland, around $50 \%$ of the L/ILW is cellulosic. ${ }^{[85]}$ In the highly alkaline environment of the CPW, cellulose is known to degrade to low molecular weight carboxylates and polyhydroxy carboxylates. ${ }^{[82-89]}$ The alkaline degradation of cellulose occurs by two different types of reaction. ${ }^{[0]}$ One possible pathway is the relatively rapid (i.e. 2 to 3 years) 'peeling-off' reaction, which converts the reducing end-group of the polysaccharide into a reactive interim product $^{[91-93]}$, which then breaks off to form the decomposition product. The second and slower path is a mid-chain scission (alkaline hydrolysis), which randomly cleaves 
glycosidic bonds within the polysaccharide chain. In the presence of calcium, the main degradation products of cellulose, up to $80 \%$, are approximately equal in amounts of 2S,4R,5-trihydroxy-2S-hydroxymethylpentanoate $\left(\alpha-\mathrm{D}\right.$-isosaccharinate, Isa $^{-}$, see Fig. 1. a) and its epimer 2R,4R,5-trihydroxy-2S-hydroxymethylpentanoate $\left(\beta-D\right.$-isosaccharinate, $\beta$-Isa ${ }^{-}$, Fig. 7). ${ }^{[94-97]}$ Calcium was shown to catalyse the benzylic acid rearrangement favouring the production of isosaccharinates. ${ }^{[94]}$ The formation of other small molecular hydroxy carboxylates (e.g., $\mathrm{Lac}^{-}$) was also detected during the alkaline degradation of cellulose. ${ }^{[86,92]}$<smiles>O=C([O-])C(O)C(CO)C(O)CO</smiles>

Figure 7. Structural formula of $\beta$-D-isosaccharinate $\left(\beta-\mathrm{Isa}^{-}\right)$.

Another important polyhydroxy carboxylate present in L/IL wastes is $\mathrm{Gluc}^{-}$(see Fig. 4), which is released from the solid matrix itself being one of the most frequently used cement additives (plasticizer) used during the processing of concrete. ${ }^{\text {[98-100] }}$ Gluconate-based concrete admixtures are used for the cement-based conditioning of waste matrices. ${ }^{[70]}$ The concentration of $\mathrm{Gluc}^{-}$in cement pore waters may range from $10^{-5}$ to $10^{-2} \mathrm{M}^{[101]}$ which is several orders of magnitude lower than that of $\alpha$-Isa ${ }^{-}$, which could reach as high as $0.1 \mathrm{M} \cdot{ }^{[85]}$ As the preparation and purification of Isa $^{-}$is rather time consuming, Gluc ${ }^{-}$, being structurally similar, has been widely used as a readily available analogue for Isa ${ }^{-[102-109]}$ Birjkumar et al., however, scrutinized the similarities between $\mathrm{Isa}^{-}$and $\mathrm{Gluc}^{-}$in U(VI) chemistry and suggested that caution should be exercised when using Gluc $^{-}$as a thermodynamic model for Isa ${ }^{-}$in such systems. ${ }^{[110]}$ Both Isa $^{-}$and Gluc ${ }^{-}$ have been shown to be effective complexing agents in the presence of actinides and lanthanides. ${ }^{[111-125]}$ As $\beta$-Isa ${ }^{-}$is rather difficult to obtain, ${ }^{[126]}$ furthermore, its complexing ability is claimed to be weaker than its epimeric form, ${ }^{[88,96]}$ research attention to date has focused almost entirely on Isa ${ }^{-}$.

In alkaline medium, the complexation of Isa $^{-}$with a series of radionuclides has been studied. ${ }^{[14,101,114]}$ Strong effects of the presence of Isa ${ }^{-}$on the sorption of Th(IV) on solid phases have been found at $\mathrm{pH}=10.7,12.0$ and 13.3 due to complex formation between Th(IV) and Isa ${ }^{-}$complexation. ${ }^{[69,106]}$ From sorption studies, the formation of the ThIsaH ${ }_{-4}^{-}$has been detected with $\log \beta_{1,1,-4}=-10.1(2)$ at $\mathrm{T}=23{ }^{\circ} \mathrm{C}$ and $\mathrm{I}=0.3 \mathrm{M}$ $\left(\mathrm{NaClO}_{4}\right)$ for the reaction $\mathrm{Th}^{4+}+\mathrm{Isa}^{-} \rightleftharpoons \mathrm{ThIsaH}_{-4}{ }^{-}+4 \mathrm{H}^{+} .{ }^{[60,61]}$ The complexation of Th(IV) with Isa $^{-}$has also been examined by liquid-liquid extraction techniques at $\mathrm{pH}=8{ }^{[111,112]}$ Stability constants, $\log \beta_{p}$, for the complexation reactions $\mathrm{Th}^{4+}+p \mathrm{Isa}^{-} \rightleftharpoons$ 
$\mathrm{ThIsa}_{p}{ }^{(4-p)+}$, were determined to be $\log \beta_{1}=12.5(5), \log \beta_{2}=19.4(4), \log \beta_{3}=21.3(3)$ at $\mathrm{T}=25^{\circ} \mathrm{C}$ and $\mathrm{I}=1.0 \mathrm{M}\left(\mathrm{NaClO}_{4}\right)$. From solubility measurements, the presence of $\mathrm{Th}(\mathrm{OH}) \mathrm{Isa}^{2+}, \mathrm{Th}(\mathrm{OH})_{3} \mathrm{Isa}_{2}{ }^{3-}$ and $\mathrm{Th}(\mathrm{OH})_{4} \mathrm{Isa}_{2}{ }^{2-}$ was deduced. The formation constants were determined to be $\log \beta_{1,1,1}=12.5(5), \log \beta_{1,3,2}=4.4(5)$ and $\log \beta_{1,4,2}=-3.2(5)$ at $\mathrm{T}=(22.0 \pm 0.2){ }^{\circ} \mathrm{C}$ and $\mathrm{I}=0 \mathrm{M}$ for the reactions $\mathrm{ThO}_{2}(\mathrm{am})+3 \mathrm{H}^{+}+\mathrm{Isa}^{-} \rightleftharpoons \mathrm{Th}(\mathrm{OH}) \mathrm{Isa}^{2+}$ $+\mathrm{H}_{2} \mathrm{O}, \mathrm{ThO}_{2}(\mathrm{am})+\mathrm{H}^{+}+2 \mathrm{Isa}^{-}+\mathrm{H}_{2} \mathrm{O} \rightleftharpoons \mathrm{Th}(\mathrm{OH})_{3} \mathrm{Isa}_{2}^{-}$and $\mathrm{ThO}_{2}(\mathrm{am})+2 \mathrm{Isa}^{-}+2 \mathrm{H}_{2} \mathrm{O}$ $\rightleftharpoons \mathrm{Th}(\mathrm{OH})_{4} \mathrm{Isa}_{2}{ }^{2-}$, respectively. ${ }^{[117]}$

In the presence of $\mathrm{U}(\mathrm{IV})$, the formation of the $\mathrm{U}(\mathrm{OH})_{4} \mathrm{Isa}^{-}$complex was shown from solubility studies at $\mathrm{T}=25^{\circ} \mathrm{C}$ and $\mathrm{I}=0.3 \mathrm{M} \cdot{ }^{[120]}$ Its formation constant was determined to be $\log \beta_{1,4,1}=49(2)$ for the reaction $\mathrm{U}^{4+}+4 \mathrm{OH}^{-}+\mathrm{Isa}^{-} \rightleftharpoons \mathrm{U}(\mathrm{OH})_{4} \mathrm{Isa}^{-}$. Rao et al. studied the complexation of Isa ${ }^{-}$with $\mathrm{U}(\mathrm{VI})$ and assumed the reactions $\mathrm{UO}_{2}{ }^{2+}+\mathrm{Isa}^{-} \rightleftharpoons \mathrm{UO}_{2} \mathrm{Isa}^{+}$, $\mathrm{UO}_{2}{ }^{2+}+2 \mathrm{Isa}^{-} \rightleftharpoons \mathrm{UO}_{2} \mathrm{Isa}_{2}{ }^{0}$ and $\mathrm{UO}_{2}{ }^{2+}+3 \mathrm{Isa}^{-} \rightleftharpoons \mathrm{UO}_{2} \mathrm{Isa}_{3}{ }^{-[11]}$ The formation constants of the different species were found to be $\log \beta_{1,1}=2.91(2), \log \beta_{1,2}=5.37$ (1) and $\log \beta_{1,3}=7.25(2)$, respectively.

$\mathrm{Np}(\mathrm{IV})$ was found to form $\mathrm{Np}(\mathrm{OH})_{2} \mathrm{Isa}_{2}{ }^{0}, \mathrm{~Np}(\mathrm{OH})_{3} \mathrm{Isa}^{0}$ and $\mathrm{Np}(\mathrm{OH})_{4} \mathrm{Isa}^{-}$as well as $\mathrm{Np}(\mathrm{OH})_{3} \mathrm{Isa}_{2}{ }^{-}$and $\mathrm{Np}(\mathrm{OH})_{4} \mathrm{Isa}_{2}{ }^{2-}$ complexes. The corresponding stability products, $\log \beta_{1, p, q}$, were determined to be $\log \beta_{1,2,2}=36.9, \log \beta_{1,3,1}=43.2$ and $\log \beta_{1,4,1}=50.14$ for the reaction $\mathrm{Np}^{4+}+p \mathrm{OH}^{-}+q \mathrm{Isa}^{-} \rightleftharpoons \mathrm{Np}(\mathrm{OH}) p \mathrm{Isa} q^{(p+q-4)-}$ as well as $\log \beta_{1,3,2}=2.11$ and $\log \beta_{1,4,2}=1.86$ for the reaction $\mathrm{Np}(\mathrm{OH})_{p} \mathrm{Isa}+\mathrm{Isa}^{-} \rightleftharpoons \mathrm{Np}(\mathrm{OH})_{p} \mathrm{Isa}_{2}{ }^{(p+2-4)-} \cdot[13,121]$

Concerning $\mathrm{Pu}(\mathrm{IV})$, the formation of two aqueous species, $\mathrm{Pu}\left(\mathrm{IsaH}_{-4}\right)^{-}$and $\mathrm{Pu}\left(\mathrm{IsaH}_{-2}\right)_{2}{ }^{2-}$ has been detected from solubility measurements. ${ }^{[122,123]}$ The corresponding formation constants were assumed to be $\log \beta=-3.50$ and $\log \beta=-0.20$ for the reactions $\mathrm{Pu}^{4+}+\mathrm{Isa}^{-} \rightleftharpoons \mathrm{PuIsaH}_{-4}{ }^{-}+4 \mathrm{H}^{+}$and $\mathrm{Pu}^{4+}+2 \mathrm{Isa}^{-} \rightleftharpoons \mathrm{PuIsa}_{2} \mathrm{H}_{-4}{ }^{2-}+4 \mathrm{H}^{+}$, respectively.

Tits et al. conducted batch-type sorption experiments to investigate the effect of Isa $^{-}$on the sorption of Am(III) by calcite. ${ }^{[106]}$ The sorption experiments were conducted in $0.3 \mathrm{M} \mathrm{NaOH}$ at $(23 \pm 3)^{\circ} \mathrm{C}$. It was found that the sorption of $\mathrm{Am}$ (III) by calcite decreased significantly when the concentration of Isa $^{-}$was above $10^{-5} \mathrm{M}$. Such effect was interpreted in terms of the formation of a 1:1 Am(III)-Isa ${ }^{-}$complex in solution.

The sorption of $\mathrm{Eu}(\mathrm{III})$ was also shown to decrease in the presence of $\mathrm{Isa}^{-}$due to complexation reactions. ${ }^{[113,115]}$ For the reaction $\mathrm{Eu}^{3+}+\mathrm{Isa}^{-} \rightleftharpoons \mathrm{Eu}\left(\mathrm{IsaH}_{-4}\right)^{2-}+\mathrm{H}^{+}, \log \beta$ was determined to be $-30.6(2)$ at $\mathrm{T}=(23 \pm 2){ }^{\circ} \mathrm{C}$ and $\mathrm{I}=0.3 \mathrm{M}\left(\mathrm{NaClO}_{4}\right) .{ }^{[60,61]}$

The complexation of $\mathrm{Gluc}^{-}$with actinides and lanthanides has also been extensively studied. Felmy studied the influence of $\mathrm{Gluc}^{-}$on $\mathrm{Th}(\mathrm{OH})_{4}(\mathrm{~s})$ solubility within the $\mathrm{pH}$ 
range 4-12 at $\mathrm{I}=0.5 \mathrm{M}\left(\mathrm{NaNO}_{3}\right)$, and found that $\mathrm{Gluc}^{-}$significantly increased the solubility of $\mathrm{Th}(\mathrm{OH})_{4}(\mathrm{~s}) .{ }^{[124]}$ In the $\mathrm{pH}$ range of 9-12, the reaction $\mathrm{Th}(\mathrm{OH})_{4}(\mathrm{am})+\mathrm{Gluc}^{-}$ $\rightleftharpoons \mathrm{Th}(\mathrm{OH})_{4}\left(\mathrm{GlucH}_{-1}\right)^{2-}+\mathrm{H}^{+}$was shown to occur with the corresponding formation constant being $\log \beta=-13.3(2)$. Colàs et al. found $\log \beta=-3.1(6)$ at $\mathrm{I}=0.5 \mathrm{M}\left(\mathrm{NaClO}_{4}\right)$ for the reaction $\mathrm{ThO}_{2} \cdot \mathrm{xH}_{2} \mathrm{O}+\mathrm{Gluc}^{-} \rightleftharpoons \mathrm{Th}(\mathrm{OH})_{2}\left(\mathrm{GlucH}_{-2}\right)^{-}+\mathrm{x} \mathrm{H}_{2} \mathrm{O}^{[108]}$

Colàs et al. found that $\mathrm{Gluc}^{-}$significantly increased the solubility of U(VI) at $\mathrm{pH}=12$. This effect was ascribed to the reaction $\mathrm{UO}_{2}(\mathrm{OH})_{3}{ }^{-}+\mathrm{Gluc}^{-} \rightleftharpoons$ $\mathrm{UO}_{2}(\mathrm{OH})_{2}\left(\mathrm{GlucH}_{-1}\right)^{2-}+\mathrm{H}_{2} \mathrm{O}$. The corresponding equilibrium constant was determined to be $\log \beta=3.9$. $^{[107]}$

In highly alkaline medium ( $\mathrm{pH}=13.3)$, the sorption of $\mathrm{Np}(\mathrm{IV})$ was also shown to decrease at Gluc concentrations higher than $10^{-6} \mathrm{M}$ due to the formation of $\mathrm{Np}(\mathrm{IV})-\mathrm{Gluc}^{-}$ complexes. ${ }^{[109]}$ For the reaction $\mathrm{Np}^{4+}+$ Gluc $^{-}+4 \mathrm{H}_{2} \mathrm{O} \rightleftharpoons \mathrm{Np}(\mathrm{OH})_{4} \mathrm{Gluc}^{-}+4 \mathrm{H}^{+}, \log \beta=$ $-4.5(3)$ was deduced.

Tits et al. found that, similarly to Isa ${ }^{-}, \mathrm{Gluc}^{-}$also decreases the sorption of both $\mathrm{Am}(\mathrm{III})$ and $\mathrm{Eu}(\mathrm{III})$ by calcite when the concentration of Gluc ${ }^{-}$was higher than $10^{-7} \mathrm{M}$. This effect was ascribed to the formation of Am(III)-Gluc ${ }^{-}$and $\mathrm{Eu}(\mathrm{III})-\mathrm{Gluc}^{-}$with $1: 1$ constitution. ${ }^{[106]}$

Giroux et al. investigated the complex formation between $\mathrm{Gluc}^{-}$and trivalent lanthanides in the $\mathrm{pH}$ range of $2-12$ by potentiometry. ${ }^{[104,105]}$ Above $\mathrm{pH}=10$, the predominant species in the $\mathrm{La}(\mathrm{III})-, \operatorname{Pr}(\mathrm{III})-, \mathrm{Eu}(\mathrm{III})-$, Dy(III)-, $\mathrm{Er}(\mathrm{III})-$ and $\mathrm{Lu}(\mathrm{III})-$ containing solutions were determined to be $\mathrm{LaGluc}_{2} \mathrm{H}_{-3}{ }^{2-}(\log \beta=-19.84(5))$ and $\mathrm{La}_{3} \mathrm{Gluc}_{2} \mathrm{H}_{-5}{ }^{-} \quad(\log \beta=-31.4(1)), \quad \operatorname{PrGluc}_{2} \mathrm{H}_{-3}{ }^{2-} \quad(\log \beta=-19.13(8)), \quad \mathrm{Eu}_{2} \mathrm{Gluc}_{2} \mathrm{H}_{-5}{ }^{-}$ $(\log \beta=-26.21(5)), \quad$ DyGluc $_{2} \mathrm{H}_{-3}{ }^{2-} \quad(\log \beta=-14.94(9)) \quad$ and $\operatorname{Pr}_{2} \mathrm{Gluc}_{2} \mathrm{H}_{-5}{ }^{-} \quad(\log \beta=$ $-20.59(4)), \operatorname{ErGluc}_{2} \mathrm{H}_{-3}{ }^{2-}(\log \beta=-13.13(7))$ and $\mathrm{Er}_{2} \mathrm{Gluc}_{2} \mathrm{H}_{-5}{ }^{-} \quad(\log \beta=-20.21(3))$, LuGluc $2 \mathrm{H}_{-3}{ }^{2-}(\log \beta=-13.30(6))$ and $\mathrm{Lu}_{2} \mathrm{Gluc}_{2} \mathrm{H}_{-5}{ }^{2-}(\log \beta=-18.16(7))$, respectively.

Considering $\mathrm{Lac}^{-}$, which is also formed during the alkaline degradation of cellulose, although in quantities significantly lower than that of $\mathrm{Isa}^{-}$, studies only performed in acidic medium are available with regard to its complex formation with lanthanides. ${ }^{[127-130]}$ The formation of $\mathrm{MLac}^{2+}, \mathrm{MLac}_{2}{ }^{+}, \mathrm{MLac}_{3}{ }^{0}$ and $\mathrm{MLac}_{4}^{-}$has been shown, where $\mathrm{M}=\mathrm{La}(\mathrm{III}), \mathrm{Ce}(\mathrm{III}), \mathrm{Pr}(\mathrm{III}), \mathrm{Nd}(\mathrm{III}), \mathrm{Sm}(\mathrm{III}), \mathrm{Eu}(\mathrm{III}), \mathrm{Gd}(\mathrm{III}), \mathrm{Tb}(\mathrm{III})$, Dy(III), Ho(III), Er(III), Tm(III), Yb(III) and Lu(III). ${ }^{[127]}$ Barkleit et al. also suggested the formation of $\mathrm{Am}(\mathrm{Lac})^{2+}, \mathrm{Am}(\mathrm{Lac})_{2}{ }^{+}$and $\mathrm{AmLac}_{3}{ }^{0}$ as well as $\mathrm{EuLac}^{2+}, \mathrm{EuLac}_{2}{ }^{+}$and EuLac $_{3}{ }^{0}$ in the presence of $\mathrm{Am}(\mathrm{III})$ and $\mathrm{Eu}(\mathrm{III})$, respectively. ${ }^{[129]} \mathrm{In} \mathrm{Nd}(\mathrm{III})$-containing solutions, the presence of $\mathrm{NdLac}^{2+}, \mathrm{NdLac}_{2}{ }^{+}$and $\mathrm{NdLac}_{3}{ }^{0}$ has been proposed. ${ }^{[130]}$ 
In the presence of $\mathrm{Ca}^{2+}$, additional processes have to be considered. On the one hand, both $\mathrm{Isa}^{-}$and $\mathrm{Gluc}^{-}$form sparingly soluble Ca-salts. The solubility products of $\mathrm{CaIsa}_{2}$ and $\mathrm{CaGluc}_{2}$ have been determined to be $\mathrm{p} K_{\mathrm{sp}}=6.53(2)$ and 4.19(5), respectively, at $\mathrm{T}=(20 \pm 1){ }^{\circ} \mathrm{C}$ and $\mathrm{I}=0 \mathrm{M} \cdot{ }^{[60,131]}$ This means that the relatively large amount of $\mathrm{Ca}^{2+}$ present in the cement pore water of L/ILW repositories decreases the concentration of the complexant. On the other hand, as the concentration of $\mathrm{Ca}^{2+}$ may be several orders of magnitude higher than that of the radionuclides, the complexing agents are more likely to form complexes with $\mathrm{Ca}^{2+}$ than with the radioactive metal ions. However, the formation of these mononuclear calcium complexes may serve as precursors in the formation of ternary, heteropolynuclear complexes. The formation of such ternary species has been reported previously. In the presence of $\mathrm{Th}(\mathrm{IV})$ and $\mathrm{Ca}^{2+}$, the $\mathrm{CaTh}(\mathrm{OH})_{4}(\mathrm{Isa})_{2}{ }^{0}$ complex has been detected by different authors. ${ }^{[69,106,132]}$ Similarly, the formation of $\mathrm{CaTh}(\mathrm{OH})_{4}(\mathrm{Gluc})_{2}$ has been shown. ${ }^{[106]} \mathrm{In}$ the simultaneous presence of $\mathrm{Pu}(\mathrm{IV})$ and $\mathrm{Ca}^{2+}$, the presence of $\mathrm{CaPu}(\mathrm{OH})_{3} \mathrm{IsaH}_{-1}{ }^{+}$and $\mathrm{CaPu}(\mathrm{OH})_{3} \mathrm{IsaH}_{-2}{ }^{0}$ complexes was proposed. ${ }^{[133,134]}$

In addition to nuclear waste leaching, in landfill where cellulosic waste and municipal solid waste incineration dry scrubber residue are co-disposed, the alkaline degradation of cellulose may mobilize metals from the dry scrubber residue. ${ }^{[135]}$ It has been estimated that as a consequence, an additional 29 tonnes of $\mathrm{Pb}, 39$ tonnes of $\mathrm{Zn}$ and 17 tonnes of $\mathrm{Cu}$ is leached annually in Sweden. The same study found that the presence

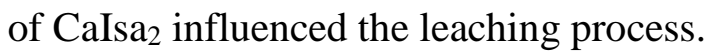




\section{Aims of the thesis}

Concerning low and intermediate level radioactive waste (L/ILW) repositories, where highly alkaline conditions prevail, small molecular polyhydroxy carboxylates may have significant impact on the mobilization of actinides and lanthanides due to their metal chelating ability. Isa ${ }^{-}$and $\mathrm{Gluc}^{-}$are considered to be the most important ligands in these systems, with other minor complexants such as $\mathrm{Lac}^{-}$. Gluc ${ }^{-}$is often considered to be a structural and functional model for Isa ${ }^{-}$. The complexation of both $\mathrm{Isa}^{-}$and $\mathrm{Gluc}^{-}$has been widely investigated in the presence of actinides and lanthanides. Little is known, however, about the complex formation between $\mathrm{Ca}^{2+}$ (which is present in relatively high concentration in L/ILW repositories) and Isa $^{-}$, especially in highly alkaline medium.

Previously, it was shown that $\mathrm{Ca}^{2+}$ was able to induce the deprotonation of polyhydroxy carboxylates forming high stability multinuclear complexes. However, it has not been investigated before whether $\mathrm{Ca}^{2+}$ was able to induce the deprotonation of oxocarboxylates.

Hence, the main aims of the present work were

- $\quad$ to investigate the $\mathrm{Ca}^{2+}-\mathrm{Isa}^{-}$system in neutral medium to determine the stability constant and the structure of the species formed, and to compare the results available for $\mathrm{Gluc}^{-}$;

- $\quad$ to examine the behaviour of Isa ${ }^{-}$in highly alkaline medium in the absence and presence of $\mathrm{Ca}^{2+}$ to determine the stability constant and the structure of the complex(es) formed, and to compare the results available for $\mathrm{Gluc}^{-}$to decide whether $\mathrm{Gluc}^{-}$is a reliable model for Isa ${ }^{-}$under repository conditions;

- $\quad$ to identify the complexes forming in solutions containing $\mathrm{Ca}^{2+}$ and $\mathrm{Lac}^{-}$both in neutral and alkaline media, and to determine the corresponding formation constants;

- $\quad$ to study the $\mathrm{Ca}^{2+}-\alpha-\mathrm{Ket}^{2-}$ system in neutral and highly alkaline medium and to deduce the formation constants of the forming complexes;

- $\quad$ to investigate the $\mathrm{Ca}^{2+}-\beta-\mathrm{Ket}^{2-}$ system in both neutral and highly alkaline solutions, and to determine the composition and formation constant of the different complexes formed. 


\section{Experimental part}

\subsection{Reagents and solutions}

During this work, all materials (listed in Table 3.) were used as received without further purification. All solutions were prepared by using deionized Milli-Q Millipore water.

Calcium chloride stock solutions were standardized against EDTA.

Carbonate-free, concentrated $\mathrm{NaOH}$ solution $(\sim 50 \mathrm{~m} / \mathrm{m} \%)$ were prepared according to the method described in ref. 136. The concentrated solution was diluted by volumetric dilution, and the resulting $\sim 1 \mathrm{M} \mathrm{NaOH}$ solution was standardized against HCl.

CaIsa $_{2}$ was prepared according to the method of Whistler and BeMiller. ${ }^{[137]}$ The original procedure was slightly modified: $220 \mathrm{~g}$ of lactose monohydrate and $60 \mathrm{~g}$ of $\mathrm{Ca}(\mathrm{OH})_{2}$ were dissolved in 21 of boiled water, and stirred for 3 days at room temperature. After this time, the mixture was boiled for $8 \mathrm{~h}$. The hot solution was filtered, and the volume of the filtrate was reduced to about $400 \mathrm{~mL}$ by evaporating the solvent. The mixture was filtered, and the crude product was recrystallized from water. The success of the synthesis was proven by $\mathrm{X}$-ray diffractometry as well as ${ }^{1} \mathrm{H}$ and ${ }^{13} \mathrm{C} \mathrm{NMR}$ spectroscopies (Fig. 8).

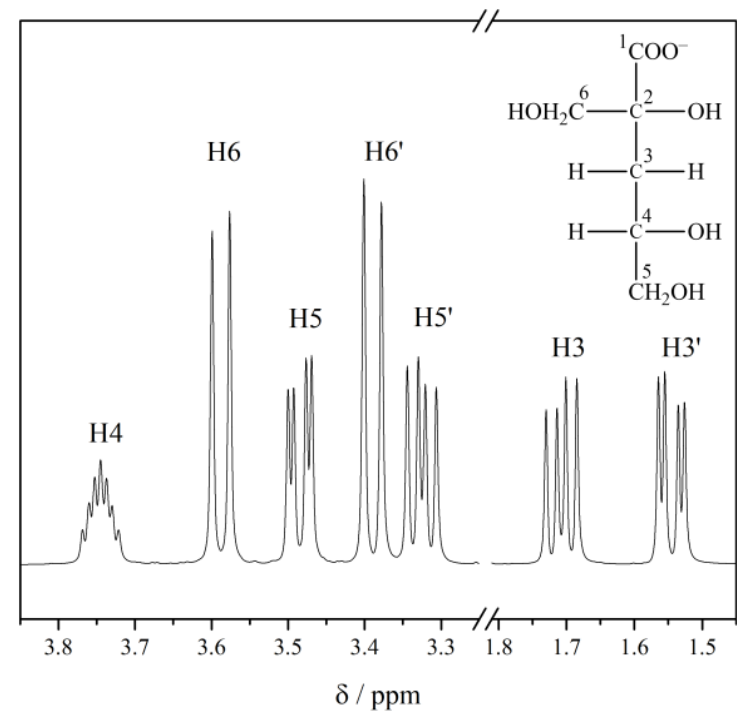

(a)

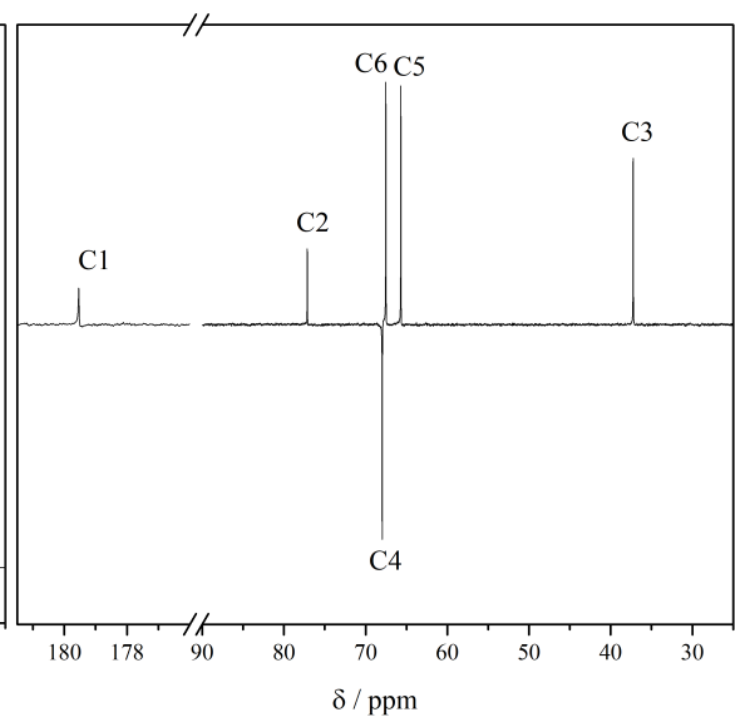

(b)

Figure 8. ${ }^{1} \mathrm{H}$ (a) and ${ }^{13} \mathrm{C}(\mathrm{b}) \mathrm{NMR}$ spectra of Isa ${ }^{-}$at $\mathrm{T}=(25 \pm 1){ }^{\circ} \mathrm{C}$. 
NaIsa stock solution was prepared as follows: $10 \mathrm{~g}$ of CaIsa 2 was stirred with proper amount of the hydrogen form of Amberlite ${ }^{\circledR}$ IR120 ion-exchange resin in about $40 \mathrm{~mL}$ water for several hours. The mixture was filtered through a $0.45 \mu \mathrm{m}$ hydrophilic PTFE membrane filter (VWR). The obtained HIsa solution was standardized against $\mathrm{NaOH}$ adjusting the $\mathrm{pH}$ to $\sim 8$. The $\mathrm{pH}$ of the solution was monitored with a calibrated $\mathrm{pH}$-sensitive glass electrode (SenTix ${ }^{\circledR} 62$ by WTW).

$\mathrm{NaLac}, \mathrm{Na}_{2}(\alpha-\mathrm{Ket})$ and $\mathrm{Na}_{2}(\beta-\mathrm{Ket})$ solutions were prepared by neutralizing a HLac, $\mathrm{H}_{2}(\alpha-\mathrm{Ket})$ and $\mathrm{H}_{2}(\beta-\mathrm{Ket})$ solutions, respectively, with $\mathrm{NaOH}$ adjusting the $\mathrm{pH}$ to $\sim 8$.

The ionic strength was set to $1 \mathrm{M}$ for the Isa ${ }^{-}$-containing systems and $4 \mathrm{M}$ for the solutions containing $\mathrm{Lac}^{-}, \alpha-\mathrm{Ket}^{2-}$ and $\beta-\mathrm{Ket}^{2-}$ using $\mathrm{NaCl}$.

Table 3. List of the materials used in this work.

\begin{tabular}{cccc}
\hline Name & Abbreviation & Purity & Supplier \\
\hline Lactose monohydrate & - & $\geq 99 \%$ & Sigma-Aldrich \\
Sodium-D-gluconate & $\mathrm{NaGluc}$ & $\geq 99 \%$ & Sigma-Aldrich \\
D,L-Lactic acid & $\mathrm{HLac}$ & $85 \%$ & Acros Organics \\
$\alpha$-Ketoglutaric acid & $\mathrm{H}_{2}(\alpha-\mathrm{Ket})$ & $\geq 99 \%$ & Sigma-Aldrich \\
$\beta$-Ketoglutaric acid & $\mathrm{H}_{2}(\beta-\mathrm{Ket})$ & $\geq 97 \%$ & Acros Organics \\
Calcium chloride dihydrate & $\mathrm{CaCl}_{2} \cdot 2 \mathrm{H}_{2} \mathrm{O}$ & $\geq 99 \%$ & Sigma-Aldrich \\
Sodium hydroxide pastilles & $\mathrm{NaOH}$ & $\geq 98.5 \%$ & VWR Chemicals \\
Sodium chloride & $\mathrm{NaCl}$ & a.r. grade & Molar Chemicals \\
Calcium hydroxide & $\mathrm{Ca}(\mathrm{OH})_{2}$ & ACS reagent & Sigma-Aldrich \\
Amberlite $\mathbb{R}$ IR120 ion & - & - & Sigma-Aldrich \\
exchange resin & & & Sigma-Aldrich \\
Deuterium oxide & $\mathrm{D}_{2} \mathrm{O}$ & $99.9 \%$ &
\end{tabular}

\subsection{Potentiometry}

Potentiometric titrations were performed using a Metrohm 794 Titrando automatic titration instrument. All measurements were carried out in a titration cell thermostated to $(25.0 \pm 0.1){ }^{\circ} \mathrm{C}$, the samples were stirred continuously during the reactions.

The complexation between $\mathrm{Ca}^{2+}$ and $\mathrm{Isa}^{-}, \mathrm{Lac}^{-}, \alpha-\mathrm{Ket}^{2-}$ and $\beta-\mathrm{Ket}^{2-}$ in (close to) neutral medium was studied via using a combined calcium ion selective electrode (Metrohm). For the calibration of the electrode, a solution containing $10^{-4} \mathrm{M} \mathrm{CaCl}_{2}$ was titrated with either $0.065 \mathrm{M}$ (for Isa ${ }^{-}$) or $0.2 \mathrm{M} \mathrm{CaCl}_{2}$ (for $\mathrm{Lac}^{-}, \alpha-\mathrm{Ket}^{2-}$ and $\beta-\mathrm{Ket}^{2-}$ ). The 
response of the Ca-ISE was found to be nonlinear in the $-4.0<\log \left(\left[\mathrm{Ca}^{2+}\right] / \mathrm{M}\right)<-1.5$ range, thus a nonlinear calibration procedure was used by fitting splines onto the calibration curve using the Spline Calculus program. ${ }^{[138]}$ Hereafter, $[\mathrm{X}]_{\mathrm{T}}$ and $[\mathrm{X}]$ denotes the total (analytical) and equilibrium concentrations of species $\mathrm{X}$, respectively.

The complex formation between $\mathrm{Ca}^{2+}$ and $\mathrm{Isa}^{-}$at highly alkaline medium was studied by $\mathrm{pH}$-potentiometric titrations, following the reactions with a platinized platinum electrode $\left(\mathrm{H}_{2} / \mathrm{Pt}\right)$ built in-house based on the procedure described in ref. 139. As a reference, a thermodynamic $\mathrm{Ag} / \mathrm{AgCl}$ electrode (built in-house) was applied. The equilibrium cell potentials were recorded in the following cell construction:

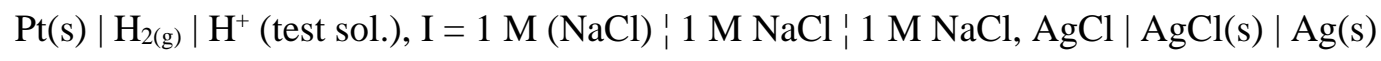

Within the employed $\mathrm{pH}$ range, the response of the electrode was found to be linear with a Nernstian slope (58.8-59.2 $\mathrm{mV})$.

During data evaluation, the $\log \left(\left[\mathrm{Ca}^{2+}\right] / \mathrm{M}\right)$ or $\mathrm{E} / \mathrm{mV}$ values for the measurements performed in neutral and alkaline media, respectively, were fitted as a function of added volume of the titrant using the PSEQUAD software ${ }^{[140]}$ through minimizing the fitting parameter $(F P) . F P$ is the average difference between the measured and the calculated data, and can be described as

$$
F P=\sqrt{\frac{\sum_{i=1}^{n}\left(Y_{i, \text { calc }}-Y_{i, \text { meas }}\right)^{2}}{n-k}}
$$

where $Y_{i, \text { calc }}$ and $Y_{i, \text { meas }}$ are the $\mathrm{i}^{\text {th }}$ calculated and measured data, respectively, $n$ is the number of measurements and $k$ is the number of fitted parameters $(n-k \equiv$ degree of freedom).

\subsection{NMR spectroscopy}

${ }^{1} \mathrm{H}$ and ${ }^{13} \mathrm{C}$ NMR spectra were recorded on a Bruker Avance DRX $500 \mathrm{MHz}$ spectrometer equipped with a $5 \mathrm{~mm}$ inverse broadband probe head furnished with $z$-oriented magnetic field gradient capability. The magnetic field was stabilized by locking it to the ${ }^{2} \mathrm{D}$ signal of the solvent prior to the measurements. The sample temperature was set to $(25 \pm 1){ }^{\circ} \mathrm{C}$ during the measurements at constant temperature and to $0-50{ }^{\circ} \mathrm{C}$ during the temperature-dependent measurements. For the individual samples, 64 and 256 or 512 scans were acquired to record the ${ }^{1} \mathrm{H}$ and ${ }^{13} \mathrm{C}$ NMR spectra, respectively. 
Each highly alkaline sample was placed into a PTFE liner, and the liner was placed into an external quartz tube containing $\mathrm{D}_{2} \mathrm{O}$. Nonlinear fitting of the ${ }^{13} \mathrm{C}$ NMR chemical shifts as a function of $\left[\mathrm{OH}^{-}\right]_{\mathrm{T}}$ or $\left[\mathrm{Ca}^{2+}\right]_{\mathrm{T}}$ was performed using the PSEQUAD program by minimizing the $F P$.

\subsection{UV spectrophotometry}

UV spectra containing $\alpha / \beta-\mathrm{Ket}^{2-}$ were recorded on a Shimadzu UV-1650 PC double beam spectrophotometer in the $200-400 \mathrm{~nm}$ wavelength range at constant $\mathrm{T}=(25 \pm 2){ }^{\circ} \mathrm{C}$ temperature. The optical path length of the quartz cuvette was $1 \mathrm{~cm}$.

Several solution sets were prepared varying either $\left[\alpha / \beta-\mathrm{Ket}^{2-}\right]_{\mathrm{T}},\left[\mathrm{OH}^{-}\right]_{\mathrm{T}}$ or $\left[\mathrm{Ca}^{2+}\right]_{\mathrm{T}}$. During calculations, the 240-300 nm (for $\alpha-\mathrm{Ket}^{2-}$ ) or the 230-300 nm (for $\beta-\mathrm{Ket}^{2-}$ ) wavelength region was evaluated with the aid of the PSEQUAD program through minimizing the FP.

The absorbance values were found to follow the Lambert-Beer rule up to as high as $\mathrm{A}=2.5$.

\subsection{Molecular modelling}

The geometry optimizations of the $\mathrm{CaGluc}^{+}, \mathrm{CaIsa}^{+}$and $\mathrm{CaIsaH}_{-1}{ }^{0}$ complexes were performed using the Gaussian 09 software package ${ }^{[141]}$ at the B3LYP/6-311++g(d,p) level ${ }^{[142,143]}$. The structures were first optimized in vacuo, and then further optimization was performed on the thus obtained structures considering implicit solvation. For these calculations, the Conductor-like Polarizable Continuum Model (CPCM) $)^{[144]}$ was utilized at the same theoretical level and with the same basis set (using water as the solvent). Finally, explicit water molecules were introduced to the optimized structures to provide a more realistic representation of the environment of the first coordination shell of $\mathrm{Ca}^{2+}$. During computations, different coordination isomers for $\mathrm{CaGluc}^{+}, \mathrm{CaIsa}^{+}$and $\mathrm{CaIsaH}_{-1}{ }^{0}$ were considered in order to find the most probable structure.

\subsection{ESI-MS measurements}

For solutions containing Isa ${ }^{-}$or $\mathrm{Lac}^{-}$, ESI-MS measurements were performed in positive ion mode using a Micromass Q-TOF Premier (Waters MS Technologies, Manchester, UK) mass spectrometer equipped with an electrospray ion source. Samples 
were introduced into the MS by using the direct injection method: the built-in syringe pump of the instrument with a Hamilton syringe was used. The electrospray needle was adjusted to $3 \mathrm{kV}$ and $\mathrm{N}_{2}$ was used as the nebulizer gas.

\subsection{ICP-OES measurements}

In order to determine the formation constant of the complex(es) formed between $\mathrm{Ca}^{2+}$ and $\mathrm{Lac}^{-}$in highly alkaline medium, solubility measurements were performed. A solution set was prepared as follows: solutions containing $\left[\mathrm{Lac}^{-}\right]_{\mathrm{T}}=0.5 \mathrm{M}$ and $\mathrm{c}_{\mathrm{NaOH}}=0.14-2.64 \mathrm{M}$ were prepared. After that, $0.2 \mathrm{~g}$ solid $\mathrm{CaO}$ were added to the solutions, then they were stirred during 24 hours at room temperature $\left((25 \pm 2){ }^{\circ} \mathrm{C}\right)$. The samples were filtered through a $0.22 \mu \mathrm{m}$ PTFE syringe filter. The filtrates were diluted to 1:100 ratio to reach optimal concentrations of $\mathrm{Ca}$ (II) as well as to decrease the ionic strength to a measurable extent, and $1 \mathrm{mg} / \mathrm{L}$ yttrium internal standard was added to each sample. The $\mathrm{pH}$ of each solution was set to $\sim 2$ with $\mathrm{HCl}$ solution to avoid the incidental dissolution of $\mathrm{CO}_{2}$ and the subsequent precipitation of $\mathrm{CaCO}_{3}$.

The total amount of $\mathrm{Ca}(\mathrm{II})$ was measured with a Perkin Elmer Optima 7000DV Inductively Coupled Plasma Optical Emission spectrometer (ICP-OES) at the wavelength values of $317.93,393.37$ and $396.85 \mathrm{~nm}$ (with using 3 replicate measurements). The signal corresponding to yttrium was collected at $371.03 \mathrm{~nm}$.

\subsection{Single crystal XRD experiments}

\subsubsection{Crystal growth}

During this work, the single crystal structures of calcium isosaccharinate and calcium gluconate have been determined.

Crystals of $\mathrm{CaIsa}_{2}$ were obtained over several days by methanol diffusion into a 1 $\mathrm{mL}$ saturated aqueous solution $(\mathrm{pH} \approx 7-8$ ) loaded into a narrow (diameter of $15 \mathrm{~mm}$ ) glass tube placed in $5 \mathrm{~mL}$ of methanol in a closed reservoir. This procedure yielded crystals of approximately $0.4 \mathrm{~mm} \times 0.1 \mathrm{~mm} \times 0.1 \mathrm{~mm}$.

Attempts to grow single crystals using the conventional method of slowly cooling saturated aqueous solutions $(\mathrm{pH} \approx 7-8)$ of $\mathrm{CaGluc}_{2}$ produced thin needles ill-suited to X-ray diffraction analysis. Accordingly, a systematic crystallization screening process was undertaken using the hanging drop vapour diffusion method in plates with 24 wells, 
varying sample concentration, precipitant type and concentration. Suitable crystals were grown from $4 \mu \mathrm{L}$ saturated aqueous solutions of $\mathrm{CaGluc}_{2}$ diluted with $4 \mu \mathrm{l}$ of $80 \%$ ethylene glycol as the precipitant over a $1 \mathrm{~mL}$ precipitant reservoir. Crystals were visible after several days and grew to approximately $0.05 \mathrm{~mm} \times 0.02 \mathrm{~mm} \times 0.01 \mathrm{~mm}$.

\subsubsection{X-ray diffraction analysis}

Computations and visualization were carried out with the assistance of WinGX, ${ }^{[145,146]}$ ShelXle, ${ }^{[147]}$ Olex2, ${ }^{[148]}$ Vesta $^{[149]}$ and XTAL. ${ }^{[150]}$ The structures were obtained by direct methods using SHELXT ${ }^{[151]}$ and extended and refined with SHELXL2017/1. ${ }^{[152,153]}$

For $\mathrm{CaGluc}_{2}$, data were collected in the UK National Crystallography Facility at the University of Southampton. ${ }^{[154]}$ The crystal was quenched at $100(1) \mathrm{K}$ in a cold nitrogen gas stream from an Oxford Cryosystems Cryostream. Data were collected with $\omega$ scans to $76^{\circ} 2 \theta$ using a Rigaku FRE instrument generating $\operatorname{Mo}(\mathrm{K} \alpha)$ radiation from a rotating anode and equipped with an AFC12 kappa goniometer and a HyPix 6000 detector. Data processing was undertaken with CrysAlisPro ${ }^{1}$ and included a multi-scan absorption correction. The absolute structure was reliably established with the Flack parameter $^{[155,156]}$ refining to $0.009(5)$.

For CaIsa2, a colourless needle-like crystal was attached with Exxon Paratone N to a nylon loop and quenched at $100(1) \mathrm{K}$ in a cold nitrogen gas stream from an Oxford Cryojet. A Pilatus 6M-F $(25 \mathrm{~Hz})$ and MD2 mini-kappa diffractometer ${ }^{[157]}$ was used for data collection employing $0.7749 \AA$ silicon double crystal monochromated synchrotron radiation $(70 \mu \mathrm{m})$ at the EMBL PETRA III P13-MX1 beamline. ${ }^{[158]}$ Data were collected with $\omega$ scans to $57^{\circ} 2 \theta$ using $\operatorname{mxCuBE}(v 2) .{ }^{[159]}$ Data processing was undertaken with XDS. ${ }^{[160]}$ The absolute structure was established with the Flack parameter ${ }^{[155,156]}$ refining to $0.059(19)$. The obtained structure was compared to the one reported previously in $1968 .^{[161]}$ 


\section{Results and discussion}

\subsection{Comparison of the calcium complexing properties of $\alpha$-D- isosaccharinate and D-gluconate}

\subsubsection{Complexation of $\mathrm{Ca}^{2+}$ by $\alpha$-D-isosaccharinate in neutral medium}

In order to determine the formation constant(s) of the complex(es) forming in neutral medium, calcium ion selective electrode (Ca-ISE) potentiometric titrations were performed at $\mathrm{I}=1.0 \mathrm{M}(\mathrm{NaCl})$ and $\mathrm{T}=25^{\circ} \mathrm{C}$. The titration curves of the Isa-containing solutions are shown in Fig. 9. The systematic decrease in $\left[\mathrm{Ca}^{2+}\right]$ with increasing $\left[\mathrm{Isa}^{-}\right]_{\mathrm{T}, 0}$ indicates complex formation. All data sets were fitted simultaneously by minimizing the $F P$. The assumption of solely the 1:1 complex ( $\mathrm{CaIsa}^{+}$, that is) was sufficient to describe the experimental data with $F P=0.02$. The optimized value for $\log \beta_{1,1}$ was found to be 1.12(2). (For the general complexation reaction see equations 7 and 8 on page 11 and 12) This stability constant corresponds to the significant (up to almost $57 \%$ ) formation of the $\mathrm{CaIsa}^{+}$complex (Fig. 10).

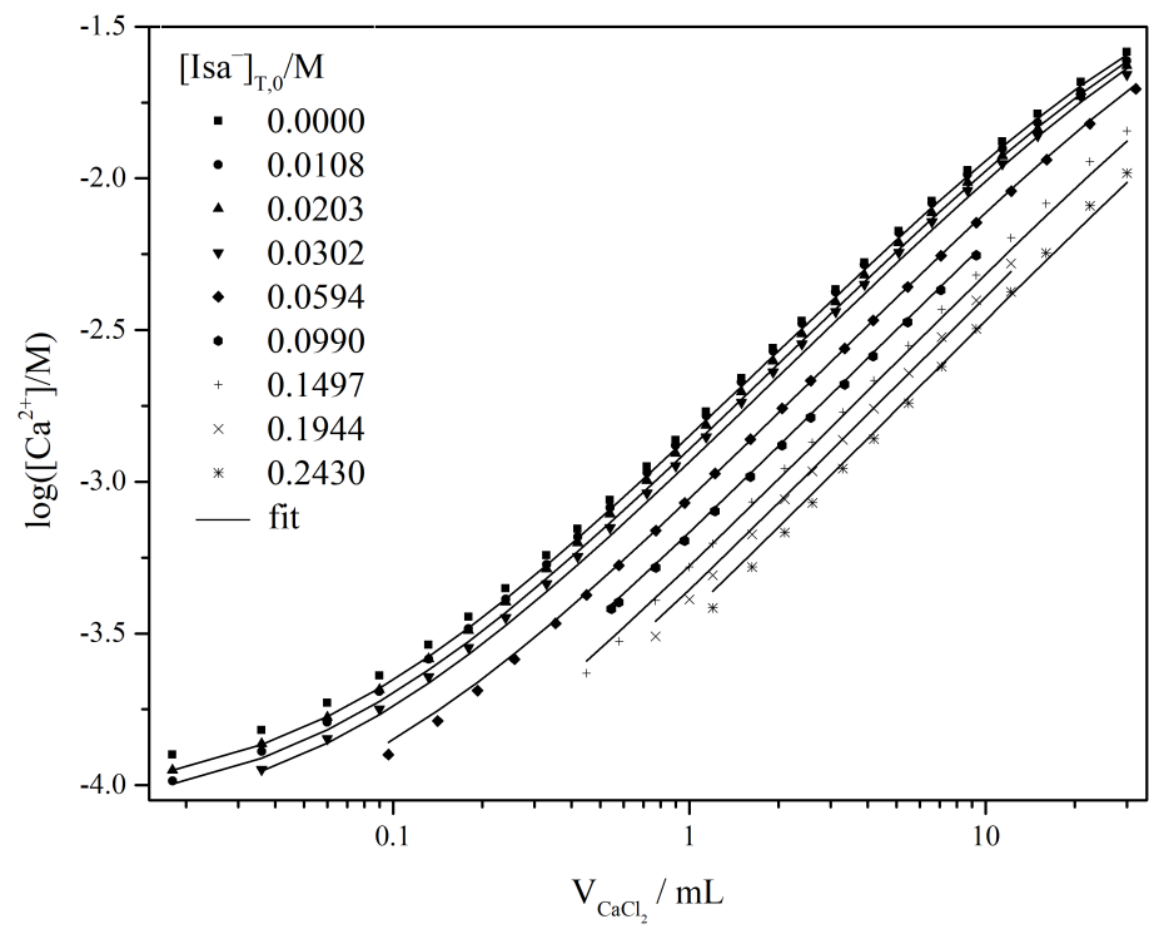

Figure 9. Ca-ISE potentiometric titration curves of solution containing $\mathrm{Isa}^{-}$and $\mathrm{Ca}^{2+}$, in neutral medium, as a function of added titrant volume (log scale). $\mathrm{V}_{0}=45 \mathrm{~mL},\left[\mathrm{Ca}^{2+}\right]_{\mathrm{T}, 0}=10^{-4} \mathrm{M}$,

titrant: $0.2 \mathrm{M} \mathrm{CaCl}_{2}$, initial $\left[\mathrm{Isa}^{-}\right]_{\mathrm{T}}$ values are shown in the figure, $\mathrm{I}=1.0 \mathrm{M}(\mathrm{NaCl})$, $\mathrm{T}=(25.0 \pm 0.1){ }^{\circ} \mathrm{C}$. Symbols and solid lines represent the measured and calculated data, respectively. 


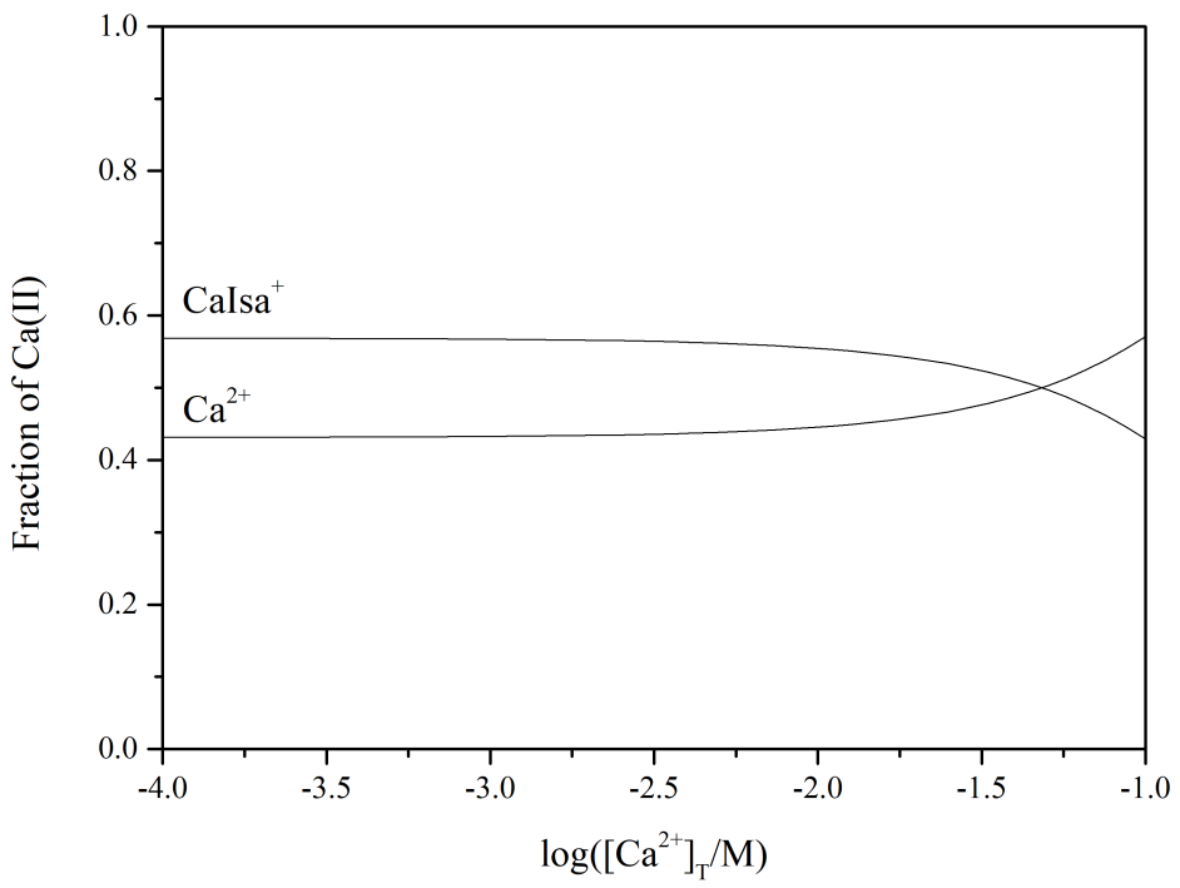

Figure 10. Distribution of $\mathrm{Ca}(\mathrm{II})$ among the aqueous species in a solution containing $\left[\mathrm{Isa}^{-}\right]_{\mathrm{T}}=$ $0.10 \mathrm{M}$ as a function of $\log \left(\left[\mathrm{Ca}^{2+}\right]_{\mathrm{T}} / \mathrm{M}\right)$.

This value is in good agreement with previous literature data obtained from Ca-ISE potentiometry $\left(\log \beta_{1,1}=1.25\right)$ and ion-exchange measurements $\left(\log \beta_{1,1}=1.29\right)$ at $\mathrm{I}=0.2 \mathrm{M}$ ionic strength. ${ }^{[50]}$

Under similar experimental conditions $\left(\mathrm{T}=25^{\circ} \mathrm{C}, \mathrm{I}=1.0 \mathrm{M} \mathrm{NaCl}\right)$, Gluc ${ }^{-}$was found to form both $\mathrm{CaGluc}^{+}$and $\mathrm{CaGluc}_{2}{ }^{0}$ complexes with the corresponding formation constants being $\log \beta_{1,1}=1.08$ and $\log \beta_{1,2}=1.65 .^{[162]}$ In the Isa-containing solutions, similar $\mathrm{CaIsa}_{2}{ }^{0}$ complex could not be detected. The difference in the composition of the solution species in the $\mathrm{Ca}^{2+}-\mathrm{Isa}^{-}$and $\mathrm{Ca}^{2+}-\mathrm{Gluc}^{-}$systems is most probably associated with the differences between the structure of the two ligands: the structure of Isa $^{-}$is branched (contains one tertiary carbon atom), while $\mathrm{Gluc}^{-}$is straight-chain (contains only primary and secondary carbon atoms). As a result, $\mathrm{Gluc}^{-}$is expected to be more flexible than Isa ${ }^{-}$. Moreover, in the "middle" of an $\mathrm{Isa}^{-}$anion, there is a lack of $\mathrm{OH}$ group (i.e. C3 is a methylene group) which forms a hydrophobic bridge between the two hydrophilic sides of the anion $(\mathrm{C} 1, \mathrm{C} 2, \mathrm{C} 6$ on one end and $\mathrm{C} 4, \mathrm{C} 5$ on the other end; for numbering, see Fig. 1 on page 4). Such hydrophobic motif is not present in $\mathrm{Gluc}^{-}$. This is likely to be the reason of the difference in the solubility of their calcium salts $\left(\mathrm{p} K_{\mathrm{sp}}\right.$ values reported for $\mathrm{CaGluc}_{2}$ and CaIsa2 are 4.19(5) and 6.53(2), respectively $\left.{ }^{[131]}\right)$. 
For comparison, the structures of both the $\mathrm{CaIsa}^{+}$and $\mathrm{CaGluc}^{+}$complexes have been optimized by molecular modelling calculations. For $\mathrm{CaIsa}^{+}$, two optimal structures have been found (Fig. 11). In Complex 1 the $\mathrm{COO}^{-}, \mathrm{C} 2-\mathrm{OH}$ and $\mathrm{C} 6-\mathrm{OH}$ groups are the binding sites. Complex 2 has the $\mathrm{Ca}^{2+}$ coordinated by the $\mathrm{COO}^{-}, \mathrm{C} 4-\mathrm{OH}$ and $\mathrm{C} 6-\mathrm{OH}$ groups. In both cases, Isa ${ }^{-}$acts as a tridentate ligand with the $\mathrm{Ca}^{2+}$ ion sitting in the nest of three oxygen donor atoms of the ligand and four water molecules resulting in a 7-fold coordination. From the point of view of thermodynamic stability, the free energy of Complex 1 is smaller by $7.2 \mathrm{~kJ} \cdot \mathrm{mol}^{-1}$ than that of Complex 2. Any other coordination mode results in considerably lower stability including those with bidentate carboxylate coordination of the metal ion. Both in Complex 1 and Complex 2, three hydrogen bonds are formed. It can be suggested that these two coordination isomers are in dynamic equilibrium, the equilibrium being shifted towards Complex 1.

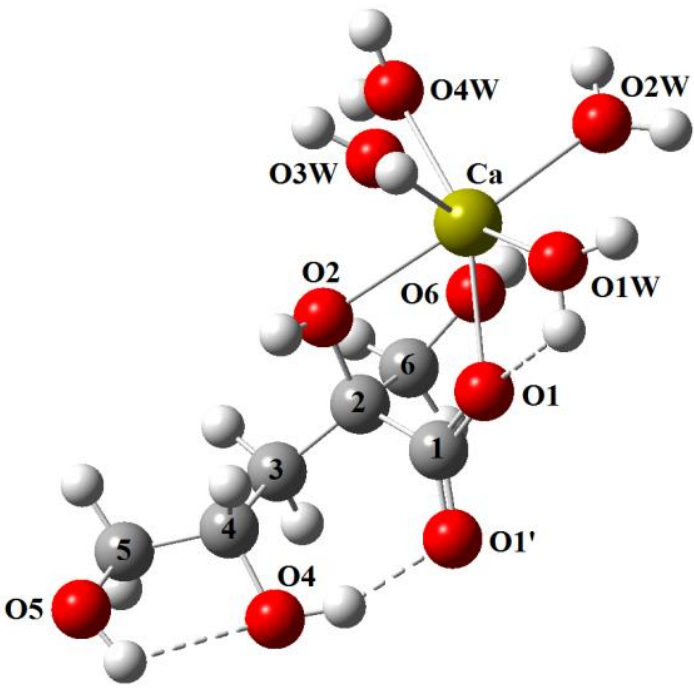

(a)

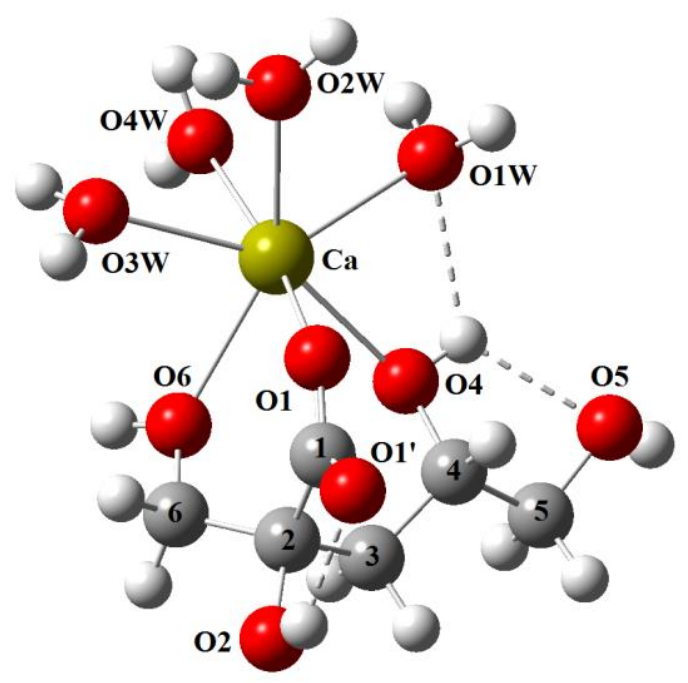

(b)

Figure 11. The optimized model structures Complex 1 (a) and Complex 2 (b) for $\mathrm{CaIsa}^{+}$. The calculations were performed at B3LYP level applying the $6-311++g(d, p)$ basis set. Solvent effects were taken into account utilizing the PCM model. Solid or dashed lines represent the $\mathrm{Ca}-\mathrm{O}$ interactions or the hydrogen bonds.

For $\mathrm{CaGluc}^{+}$, NMR studies of ${ }^{1} \mathrm{H}-{ }^{43} \mathrm{Ca}$ interactions suggest that the primary metal binding sites of $\mathrm{Gluc}^{-}$are the $\mathrm{COO}^{-}, \mathrm{C} 2-\mathrm{OH}$ and $\mathrm{C} 3-\mathrm{OH}$ groups ${ }^{[163]}$ (for numbering, see Fig. 4 on page 8 ). In accordance with previous results, ${ }^{[163,164]}$ it was found that in the continuum of implicit solvent molecules model, the most stable structure involved the binding of the $\mathrm{O} 1, \mathrm{O} 2$ and $\mathrm{O} 3$ oxygens. Surprisingly, the $\mathrm{Ca}-\mathrm{O} 2$ interaction becomes unfavourable on introducing four $\mathrm{H}_{2} \mathrm{O}$ molecules into the model structure (Fig. 12). The 
lowest-energy structure, Complex 3, has the metal ion bound to the carboxylate and C3-OH groups, the coordination number being 6. In Complex $4, \mathrm{Ca}^{2+}$ binds to the $\mathrm{COO}^{-}$ and $\mathrm{C} 2-\mathrm{OH}$ groups. The free energy of this isomer is only $3.4 \mathrm{~kJ} \cdot \mathrm{mol}^{-1}$ higher than that of Complex 3. In both Complex 3 and Complex 4, Gluc ${ }^{-}$acts as a bidentate ligand, furthermore, several hydrogen bonds are formed in both isomers.

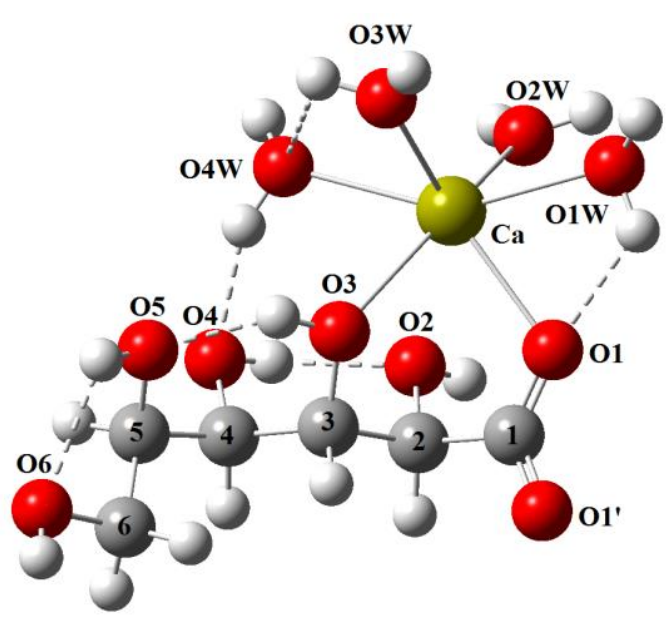

(a)

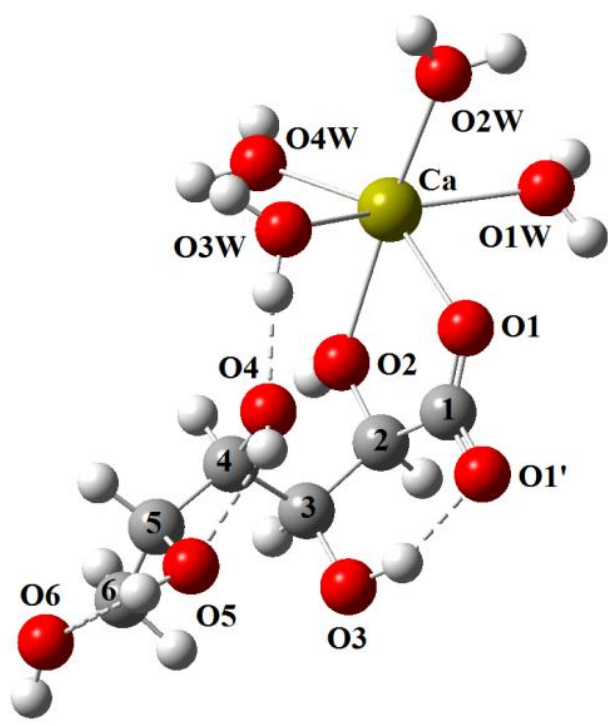

(b)

Figure 12. The optimized model structures Complex 2 (a) and Complex 3 (b) for CaGluc ${ }^{+}$. The calculations were performed at B3LYP level applying the 6-311++g(d,p) basis set. Solvent effects were taken into account utilizing the PCM model. Solid or dashed lines represent the $\mathrm{Ca}-\mathrm{O}$ interactions or the hydrogen bonds.

\subsubsection{Deprotonation of $\alpha$-D-isosaccharinate in alkaline medium}

The alkaline deprotonation of $\mathrm{Isa}^{-}$was investigated by ${ }^{1} \mathrm{H}$ and ${ }^{13} \mathrm{C}$ NMR spectroscopic measurements in solutions containing $\left[\mathrm{Isa}^{-}\right]_{\mathrm{T}}=0.050 \mathrm{M}$ or $0.100 \mathrm{M}$ and $\left[\mathrm{OH}^{-}\right]_{\mathrm{T}}=0-1.00 \mathrm{M}$. The ${ }^{13} \mathrm{C}$ NMR peaks were found to shift downfield with increasing $\mathrm{NaOH}$ concentration indicating that $\mathrm{OH}$ deprotonation occurred (Fig. 13). The extent of this variation is $0.08-0.55 \mathrm{ppm}$.

Since the proton exchange between $\mathrm{Isa}^{-}$and $\mathrm{IsaH}_{-1}{ }^{2-}$ is fast on the ${ }^{13} \mathrm{C} \mathrm{NMR}$ timescale, the following equation could be used:

$$
\delta_{\text {obs }}=\frac{\delta_{\text {Isa }^{-}}\left[\mathrm{Isa}^{-}\right]+\delta_{\mathrm{IsaH}_{-1}^{2-}}\left[\mathrm{IsaH}_{-1}^{2-}\right]}{\left[\mathrm{Isa}^{-}\right]_{\mathrm{T}}}
$$

where $\delta_{\text {obs }}$ is the observed chemical shift, $\delta_{\mathrm{Isa}^{-}}$and $\delta_{\mathrm{IsaH}_{-1}{ }^{2-}}$ are the limiting chemical 
shifts of Isa $^{-}$and $\mathrm{IsaH}_{-1}{ }^{2-}$, respectively. The thus obtained deprotonation constant is $\mathrm{p} K_{\mathrm{a}}=14.5(1)$ using 13.76 as $\mathrm{p} K_{\mathrm{w}}$, the ionic product of water, for $\mathrm{I}=1.0 \mathrm{M} \mathrm{NaCl} \cdot{ }^{[165]}$ For this dissociation constant, the extent of deprotonation is $c a .20 \%$ at $\mathrm{pH}=14$.

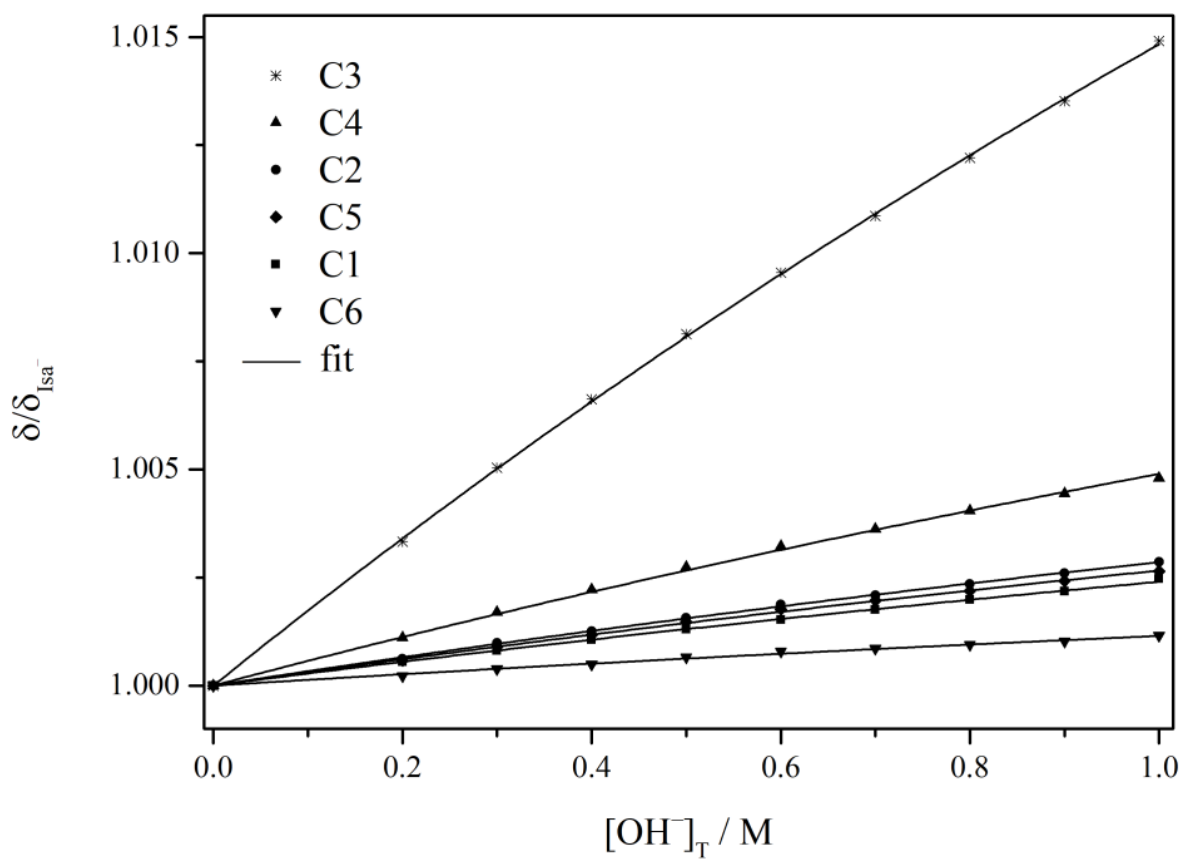

Figure 13. ${ }^{13} \mathrm{C}$ NMR chemical shifts of each carbon atom (normalized to those of the neat Isa ion) as a function of $\left[\mathrm{OH}^{-}\right]_{\mathrm{T}}$. $\left[\mathrm{Isa}^{-}\right]_{\mathrm{T}}=0.100 \mathrm{M}, \mathrm{T}=(25 \pm 1){ }^{\circ} \mathrm{C}, \mathrm{I}=1.0 \mathrm{M}(\mathrm{NaCl})$. Symbols and solid lines represent the measured and calculated data, respectively.

The ${ }^{1} \mathrm{H}$ NMR signals of Isa $^{-}$exhibited an upfield shift with increasing $\mathrm{NaOH}$ concentration. This small but detectable variation $(\Delta \delta<0.1 \mathrm{ppm})$ indicates the deprotonation of the ligand, but the magnitude of these changes makes the ${ }^{1} \mathrm{H} N M R$ spectra unsuitable for extracting $\log K_{\mathrm{a}}$. The almost uniform variation in the chemical shifts of each proton signal upon increasing $\mathrm{NaOH}$ concentration indicates the deprotonation of the alcoholic $\mathrm{OH}$ groups without a favoured position for the deprotonation.

For Gluc ${ }^{-}$, a value of $\mathrm{p} K_{\mathrm{a}}=13.68(3)$ was determined under similar experimental conditions $\left(\mathrm{T}=25^{\circ} \mathrm{C}, \mathrm{I}=1.0 \mathrm{M} \mathrm{NaCl}\right)$ from $\mathrm{H}_{2} / \mathrm{Pt}$ potentiometry. ${ }^{[47]}$ This value is almost one order of magnitude lower than that determined for Isa ${ }^{-}$indicating that Isa $^{-}$is a significantly weaker acid than Gluc ${ }^{-}$. 


\subsubsection{Complexation of $\mathrm{Ca}^{2+}$ by $\alpha$-D-isosaccharinate in alkaline medium}

The ${ }^{1} \mathrm{H}$ NMR spectra of solutions containing $\left[\mathrm{Isa}^{-}\right]_{\mathrm{T}}=0.20 \mathrm{M},\left[\mathrm{OH}^{-}\right]_{\mathrm{T}}=0.50 \mathrm{M}$ and $\left[\mathrm{Ca}^{2+}\right]_{\mathrm{T}}=0-0.10 \mathrm{M}$ are shown in Fig. 14. For comparison, the spectra of solutions with identical compositions, but with Gluc ${ }^{-}$in place of Isa ${ }^{-}$are also shown (Fig. 15).

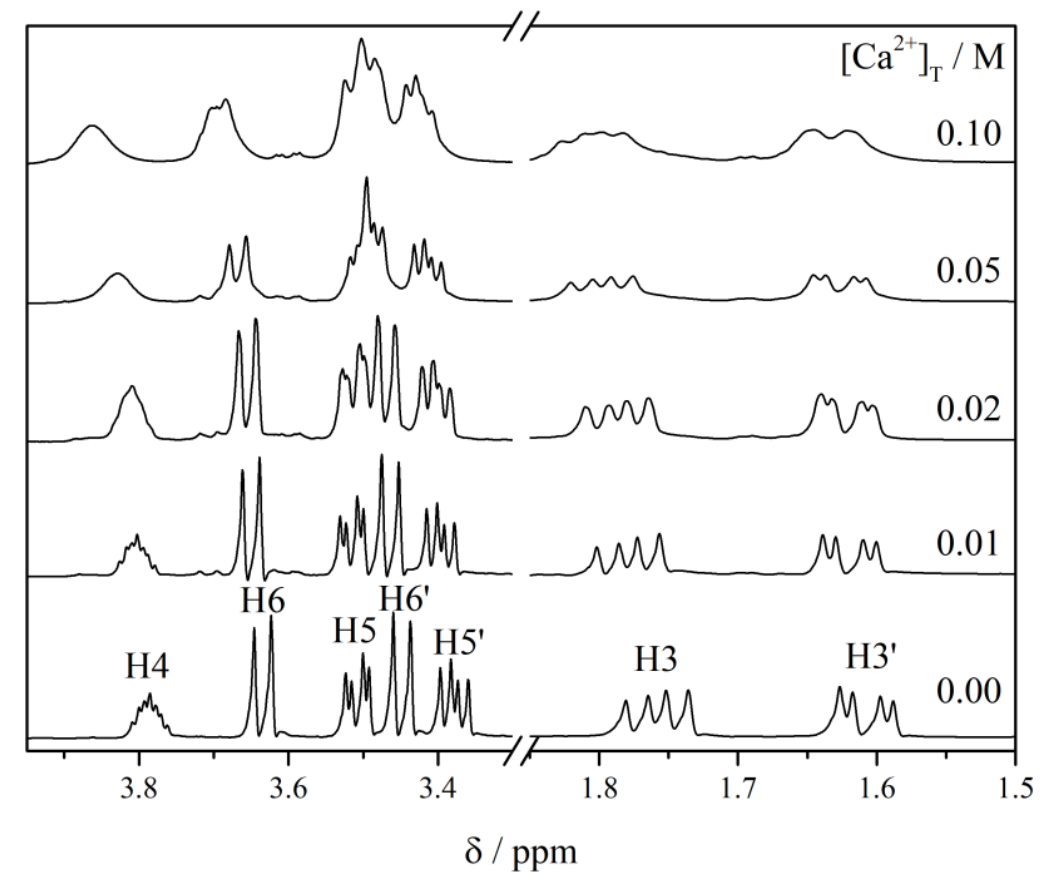

Figure 14. ${ }^{1} \mathrm{H}$ NMR spectra of solutions containing $\left[\mathrm{Isa}^{-}\right]_{\mathrm{T}}=0.20 \mathrm{M},\left[\mathrm{OH}^{-}\right]_{\mathrm{T}}=0.50 \mathrm{M}$ and $\left[\mathrm{Ca}^{2+}\right]_{\mathrm{T}}=0-0.10 \mathrm{M} . \mathrm{T}=(25 \pm 1)^{\circ} \mathrm{C}, \mathrm{I}=1.0 \mathrm{M}(\mathrm{NaCl})$.

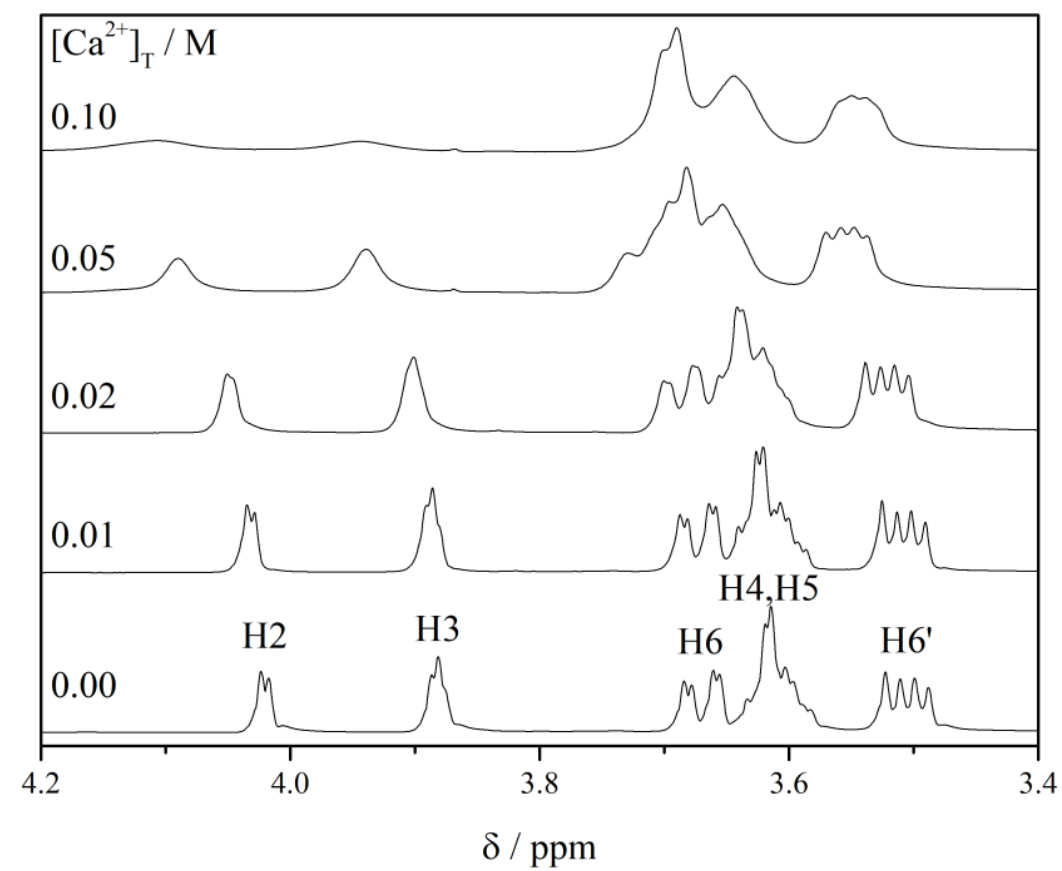

Figure 15. ${ }^{1} \mathrm{H}$ NMR spectra of solutions containing $\left[\mathrm{Gluc}^{-}\right]_{\mathrm{T}}=0.20 \mathrm{M},\left[\mathrm{OH}^{-}\right]_{\mathrm{T}}=0.50 \mathrm{M}$ and $\left[\mathrm{Ca}^{2+}\right]_{\mathrm{T}}=0-0.10 \mathrm{M} . \mathrm{T}=(25 \pm 1){ }^{\circ} \mathrm{C}, \mathrm{I}=1.0 \mathrm{M}(\mathrm{NaCl})$. 
Addition of $\mathrm{Ca}^{2+}$ ions to the $\mathrm{Isa}^{-}$-containing system causes minor but detectable effects in the ${ }^{1} \mathrm{H}$ NMR spectrum: the peaks are shifted downfield and broadened. The most profound change occurred in the signal of $\mathrm{H} 4$. These observations indicate that complex formation occurs between $\mathrm{Ca}^{2+}$ and $\mathrm{Isa}^{-}$. Much more remarkable changes, however, are seen in the Gluc ${ }^{-}$-containing solutions upon addition of $\mathrm{Ca}^{2+}$. The displacement of the peaks is significantly larger, and the extent of line broadening is so extensive that at $\left[\mathrm{Ca}^{2+}\right]_{\mathrm{T}}=0.1 \mathrm{M}$ (where the metal-to-ligand ratio is 1:2), the peaks of the $\mathrm{H} 2$ and $\mathrm{H} 3$ protons practically merge to the baseline. The profound difference between the two spectral series suggests that under these experimental conditions, $\mathrm{Ca}^{2+}$ ions form complexes more readily with $\mathrm{Gluc}^{-}$than with Isa ${ }^{-}$. To further enhance the experimental effect seen in Fig. 14, the metal-to-ligand ratio should be increased. In this concentration range, however, $\mathrm{CaIsa}_{2}(\mathrm{~s})$ precipitation occurred in the system right after solution preparation. Such precipitate formation was also observed at lower total concentrations too, however, the spectra exhibited variation only after the onset of the precipitation (Fig. 16). Before that, the spectra are independent of the time elapsed since solution preparation. This indicates that the simultaneous solution equilibria are very rapidly established between the solution species even in supersaturated solutions.

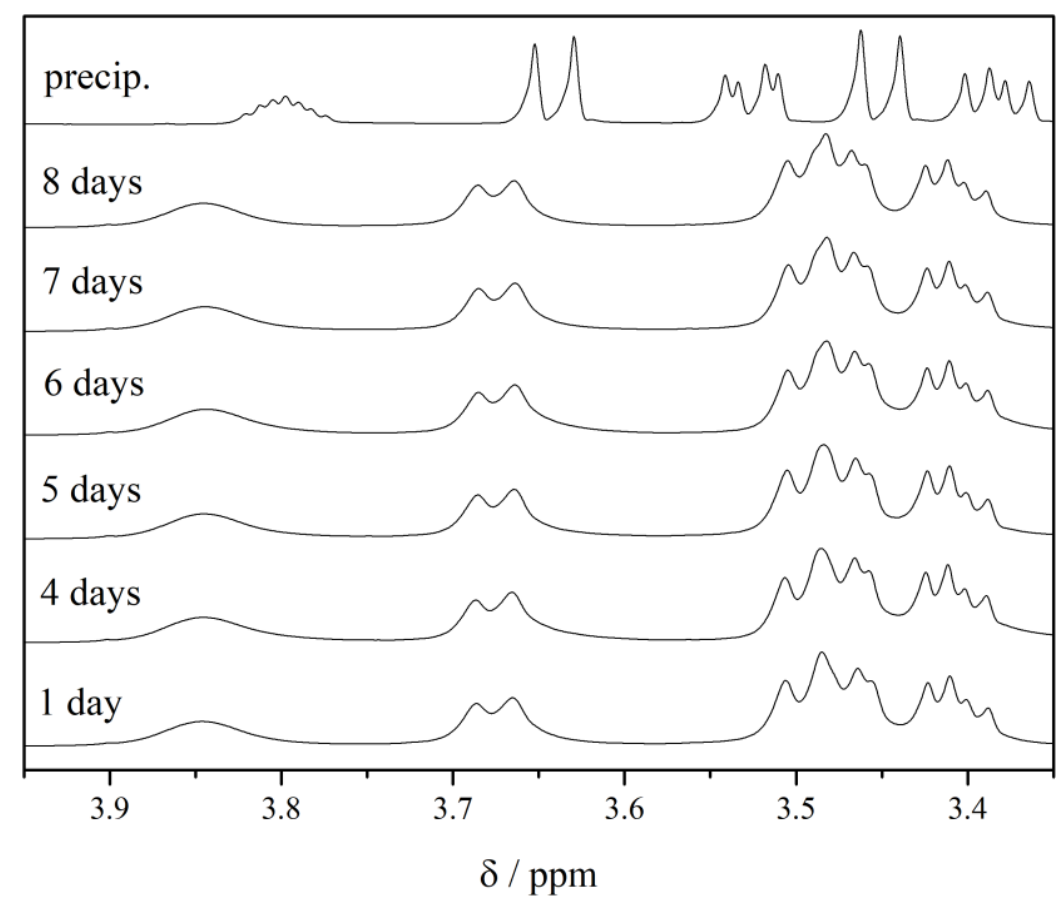

Figure 16. Time dependence of the ${ }^{1} \mathrm{H}$ NMR spectra of a solution containing $\left[\mathrm{Isa}^{-}\right]_{\mathrm{T}}=0.20 \mathrm{M}$, $\left[\mathrm{OH}^{-}\right]_{\mathrm{T}}=0.50 \mathrm{M}$ and $\left[\mathrm{Ca}^{2+}\right]_{\mathrm{T}}=0.10 \mathrm{M}, \mathrm{T}=(25 \pm 1)^{\circ} \mathrm{C}, \mathrm{I}=1.0 \mathrm{M}(\mathrm{NaCl})$. The spectrum at the top corresponds to the filtrate after removing the precipitate formed after 8 days. 
In order to quantitatively characterize the composition of the complex(es) formed, $\mathrm{pH}$ potentiometric titrations were performed using a $\mathrm{H}_{2} / \mathrm{Pt}$ electrode. The observed cell potentials are shifted towards the less negative values for solutions containing both $\mathrm{Ca}^{2+}$ and $\mathrm{Isa}^{-}$assuming that $\mathrm{OH}^{-}$consuming process(es) occur(s) (Fig. 17). The potentiometric effect is at most $\sim 12 \mathrm{mV}$. In contrast, a much larger effect (up to $50 \mathrm{mV}$ ) and a unique curvature was seen on the titration curves of the $\mathrm{Gluc}^{-}$-containing solutions (Fig. 18). This confirms the semi-quantitative statement derived from the ${ }^{1} \mathrm{H}$ NMR measurements that Gluc $^{-}$forms more stable calcium complexes in alkaline medium than Isa ${ }^{-}$does.

During data evaluation, the formation constant of the following species were kept constant (the corresponding $\log \beta$ values in brackets): IsaH $_{-1}{ }^{2-}\left(\mathrm{p} K_{\mathrm{a}}=14.5\right), \mathrm{CaIsa}^{+}$ ( $\log \beta=1.12), \mathrm{CaOH}^{+}(\log \beta=-13.58)^{[166]}$ and $\mathrm{Ca}(\mathrm{OH})_{2}(\log \beta=-26.85) .{ }^{[166]}$ Assumption of only one mononuclear complex, $\mathrm{CaIsaH}_{-1}{ }^{0}$ was sufficient to fit the experimentally observed cell potentials with $F P=0.82 \mathrm{mV}$, the corresponding formation constant was determined to be $\log \beta_{1,1,-1}=-11.36(2)$. This formation constant corresponds to significant formation of the $\mathrm{CaIsaH}_{-1}^{0}$ species (Fig. 19). The presence of such 1:1:-1 complex was also shown in the Gluc -containing solutions, its formation constant was determined to be $\log \beta_{1,1,-1}=-10.94(1) .{ }^{[47]}$

It is interesting to note that the formation constant referring to the direct association reaction between $\mathrm{Ca}^{2+}$ and $\mathrm{IsaH}_{-1}{ }^{2-}$, defined as

$$
K_{1,1,-1}=\frac{\left[\mathrm{CaIsaH}_{-1}{ }^{0}\right] \mathrm{c}^{\ominus}}{\left[\mathrm{Ca}^{2+}\right]\left[\mathrm{IsaH}_{-1}{ }^{2-}\right]}=\frac{\beta_{1,1,-1}}{K_{\mathrm{a}}}
$$

was calculated to be 3.13 , which is considerably larger than the value determined for the $\mathrm{CaGlucH}_{-1}{ }^{0}$ complex $(2.74)^{[47]}$. This is in line with the observation that $\mathrm{IsaH}_{-1}{ }^{2-}$ is a stronger base than $\mathrm{GlucH}_{-1}{ }^{2-}$.

In the Gluc ${ }^{-}$-containing systems, however, the presence of two high-stability polynuclear complexes $\left(\mathrm{Ca}_{2} \mathrm{GlucH}_{-3}{ }^{0}\right.$ and $\left.\mathrm{Ca}_{3} \mathrm{Gluc}_{2} \mathrm{H}_{-4}{ }^{0}\right)$ was shown beside the $\mathrm{CaGlucH}_{-1}{ }^{0}$ species, furthermore, these polynuclear complexes were found to be the predominant species (Fig. 20). For Isa ${ }^{-}$, including such polynuclear complexes to the model did not improve the FP. 


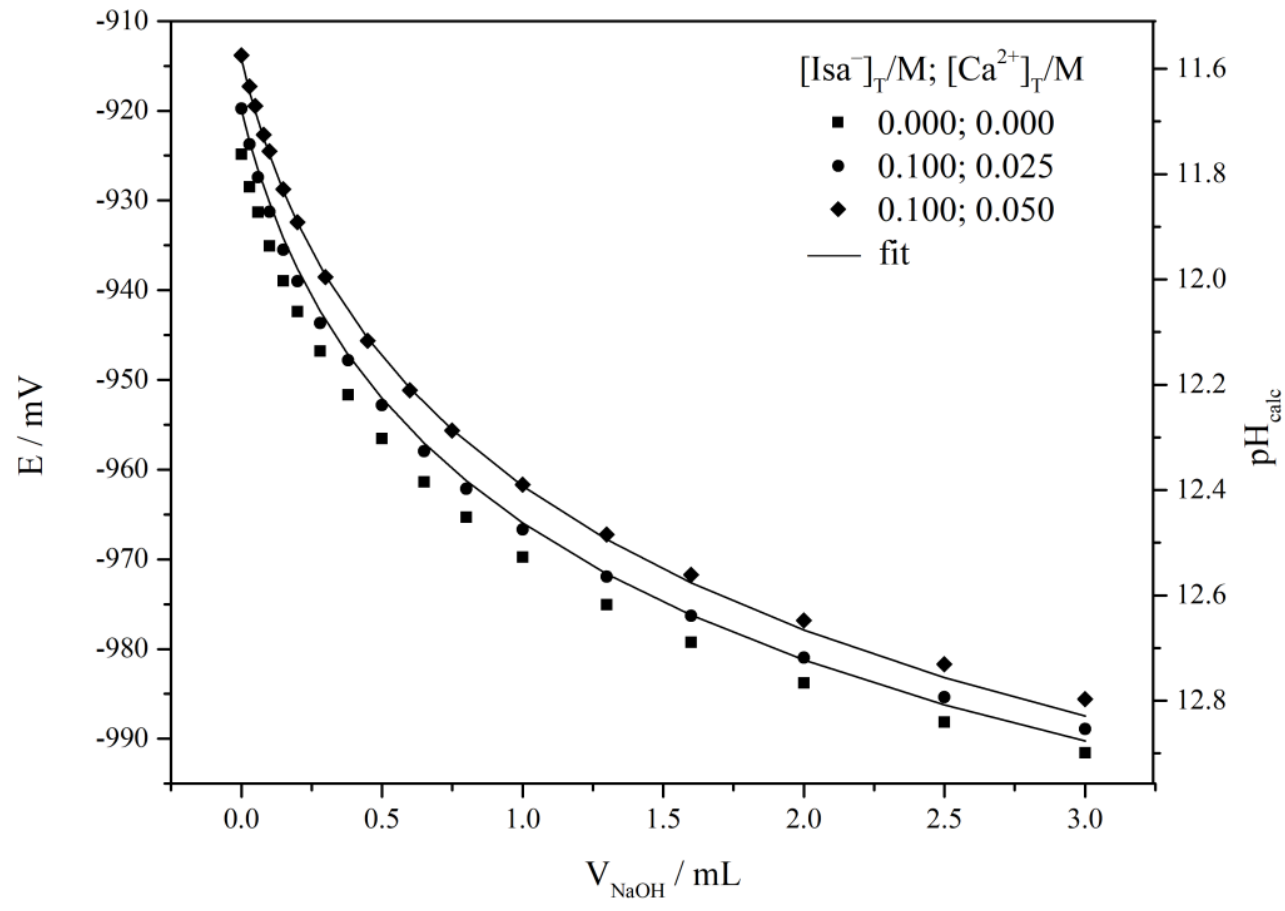

Figure 17. $\mathrm{H}_{2} / \mathrm{Pt}$ electrode potentiometric titration curves of alkaline solutions containing $\mathrm{Isa}^{-}$ and $\mathrm{Ca}^{2+}$ in terms of added titrant volume. The right axis indicates the $\mathrm{pH}$ values based on the calculated proton concentrations. $\mathrm{V}_{0}=20 \mathrm{~mL},\left[\mathrm{OH}^{-}\right]_{\mathrm{T}, 0}=0.010 \mathrm{M}$, titrant: $[\mathrm{NaOH}]_{\mathrm{T}}=1.00 \mathrm{M}$, initial $\left[\mathrm{Isa}^{-}\right]_{\mathrm{T}}$ and $\left[\mathrm{Ca}^{2+}\right]_{\mathrm{T}}$ values are shown in the figure, $\mathrm{T}=(25.0 \pm 0.1)^{\circ} \mathrm{C}, \mathrm{I}=1.0 \mathrm{M}(\mathrm{NaCl})$.

Symbols and solid lines correspond to the measured and fitted data, respectively.

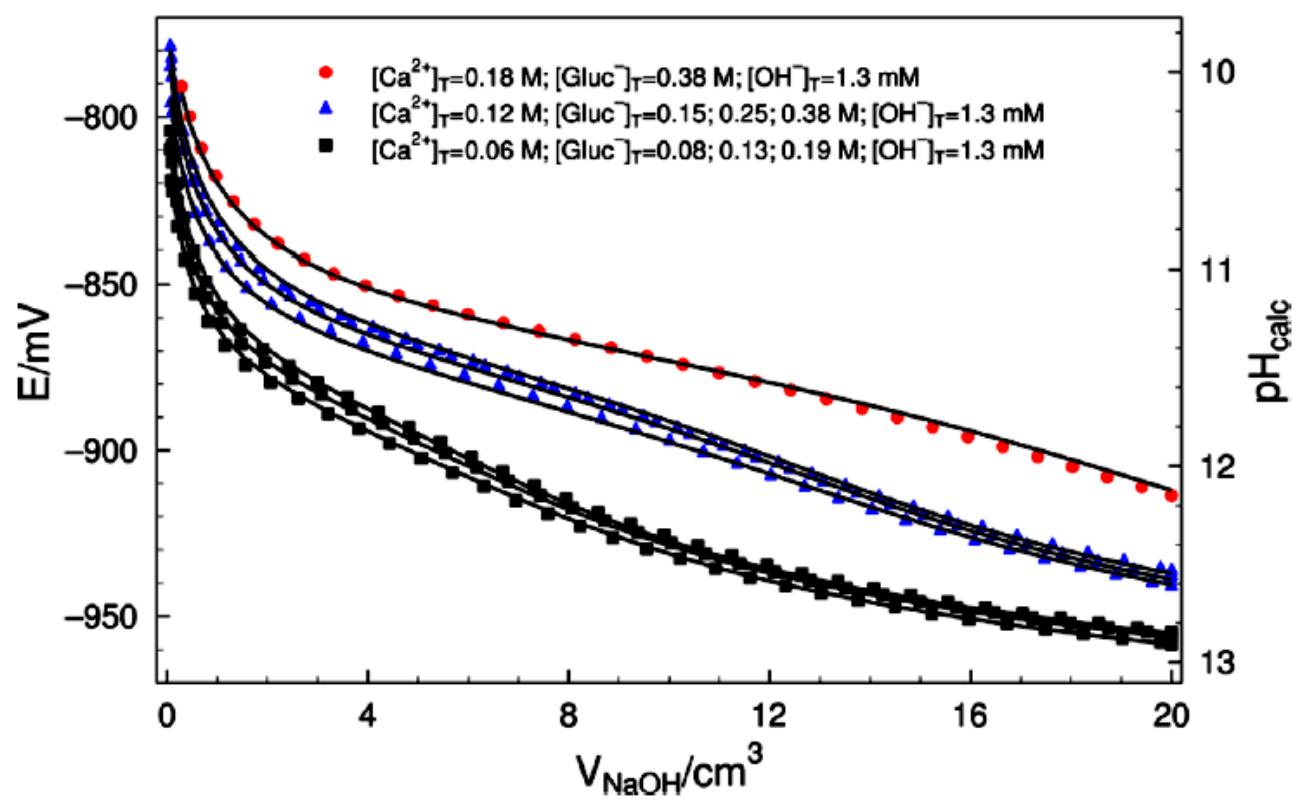

Figure 18. $\mathrm{H}_{2} / \mathrm{Pt}$ electrode potentiometric titration curves of the systems containing $\mathrm{Ca}^{2+}$ and $\mathrm{Gluc}^{-}$as a function of the added titrant volume. The right axis indicates the $\mathrm{pH}$ values based on the calculated proton concentrations. Initial $\left[\mathrm{Ca}^{2+}\right]_{\mathrm{T}}$, $\left[\mathrm{Gluc}^{-}\right]_{\mathrm{T}}$ and $\left[\mathrm{OH}^{-}\right]_{\mathrm{T}}$ values are shown in the figure. Symbols and solid lines represent the measured and calculated data, respectively. Titrant: $1.03 \mathrm{M} \mathrm{NaOH}, \mathrm{T}=(25.00 \pm 0.04){ }^{\circ} \mathrm{C}, \mathrm{I}=1.0 \mathrm{M}(\mathrm{NaCl})$. This figure was taken from Ref. 47. 


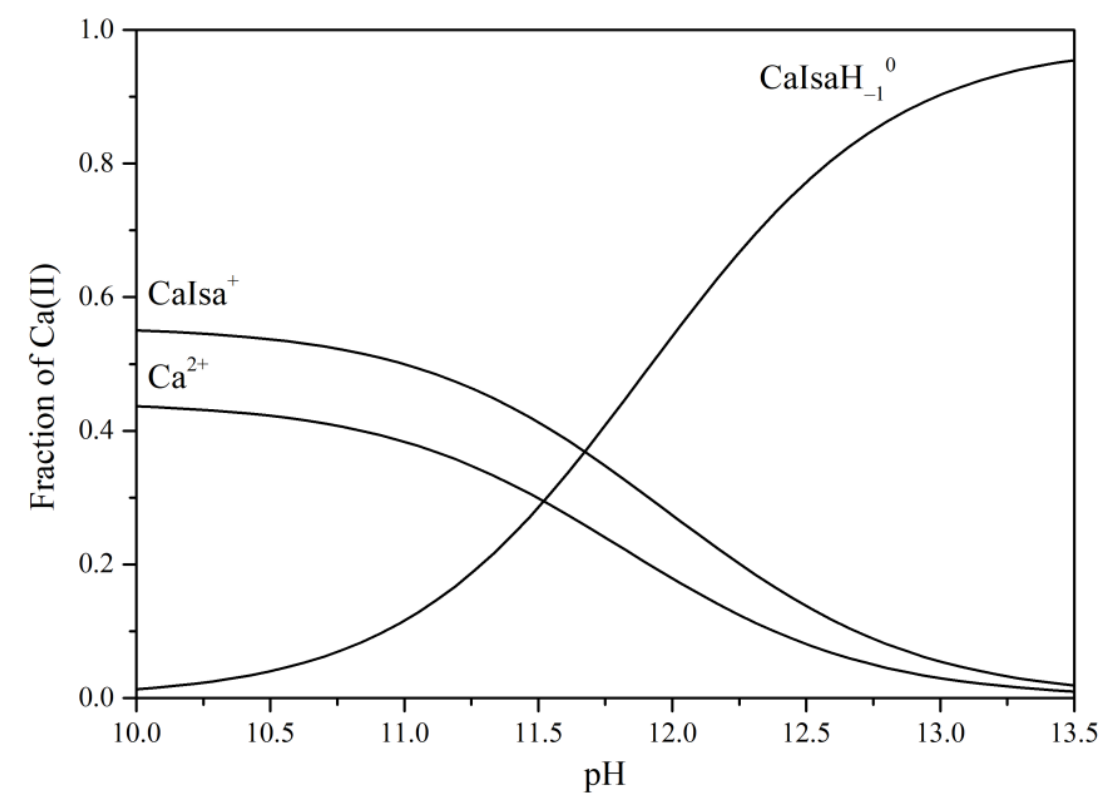

Figure 19. Distribution of $\mathrm{Ca}(\mathrm{II})$ among the various aqueous species in a solution containing $\left[\mathrm{Isa}^{-}\right]_{\mathrm{T}}=0.10 \mathrm{M},\left[\mathrm{Ca}^{2+}\right]_{\mathrm{T}}=0.05 \mathrm{M}$ as a function of $\mathrm{pH}$.

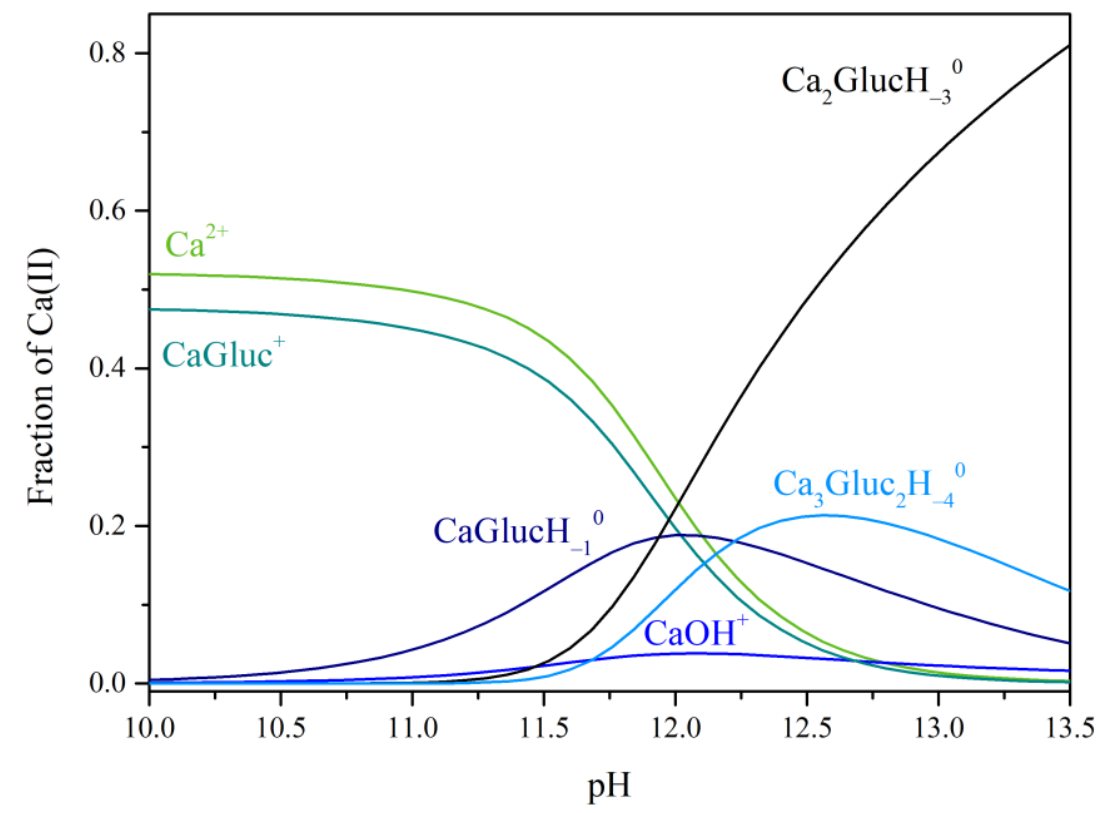

Figure 20. Distribution of $\mathrm{Ca}(\mathrm{II})$ among the various aqueous species in a solution containing $\left[\mathrm{Gluc}^{-}\right]_{\mathrm{T}}=0.10 \mathrm{M},\left[\mathrm{Ca}^{2+}\right]_{\mathrm{T}}=0.05 \mathrm{M}$ as a function of $\mathrm{pH}$.

In order to obtain further information on the composition of the solution species present in alkaline $\mathrm{Ca}^{2+}-\mathrm{Isa}^{-}$solutions, ESI-MS measurements were performed. The ESIMS spectrum of a solution containing $\left[\mathrm{Ca}^{2+}\right]_{\mathrm{T}}=0.025 \mathrm{M},\left[\mathrm{Isa}^{-}\right]_{\mathrm{T}}=0.050 \mathrm{M}$ and $\left[\mathrm{OH}^{-}\right]_{\mathrm{T}}=0.100 \mathrm{M}$ was recorded in positive ion mode (Fig. 21). As uncharged complexes are invisible in ESI-MS, the peaks referring to the solution species appeared in the spectrum gaining positive charge(s) via "binding" one (or more) proton(s). Therefore, the peak referring to $\mathrm{CaIsaH}_{-1}{ }^{0}$ is expected to appear at $219.0182 \mathrm{~m} / \mathrm{z}$. Polynuclear complexes 
with compositions similar to those found for the $\mathrm{Ca}^{2+}-\mathrm{Gluc}^{-}-\mathrm{OH}^{-}$systems (i.e. $\mathrm{Ca}_{2} \mathrm{IsaH}_{-}$ $3^{0}$ and $\mathrm{Ca}_{3} \mathrm{Isa}_{2} \mathrm{H}_{-4}{ }^{0}$ ) are expected to appear at around 257 and $475 \mathrm{~m} / \mathrm{z}$ values. In the Isa- $^{-}$-containing system, however, the experimentally observed mass spectrum was practically empty in this range.

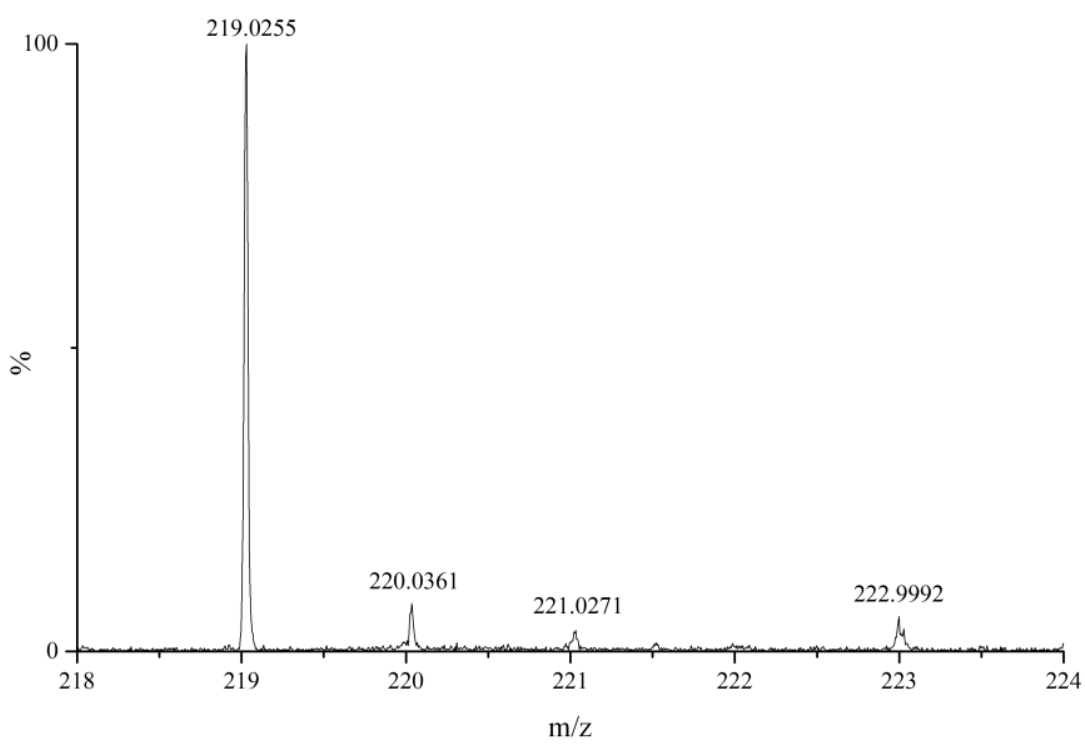

Figure 21. ESI-MS spectrum of a solution containing $\left[\mathrm{Isa}^{-}\right]_{\mathrm{T}}=0.05 \mathrm{M},\left[\mathrm{Ca}^{2+}\right]_{\mathrm{T}}=$ and $\left[\mathrm{OH}^{-}\right]_{\mathrm{T}}=0.100 \mathrm{M}$. The peak at 219.0255 corresponds to the $\mathrm{CaIsa}^{+}$species (formed by the protonation of the $\mathrm{CaIsaH}_{-1}{ }^{0}$ species, predominant in this solution).

In order to identify the binding sites of the ligand in the $\mathrm{CaIsaH}_{-1}{ }^{0}$ complex, ${ }^{1} \mathrm{H}$ and ${ }^{13} \mathrm{C}$ NMR experiments were performed. The temperature dependent ${ }^{1} \mathrm{H}$ NMR spectrum series of a solution containing $\left[\mathrm{Isa}^{-}\right]_{\mathrm{T}}=0.2 \mathrm{M},\left[\mathrm{OH}^{-}\right]_{\mathrm{T}}=0.2 \mathrm{M}$ and $\left[\mathrm{Ca}^{2+}\right]_{\mathrm{T}}=0.1 \mathrm{M}$ (Fig. 22) shows that the chemical exchange between the various forms of the ligand is slow on the ${ }^{1} \mathrm{H}$ NMR time scale below $5^{\circ} \mathrm{C}$, while it becomes fast by increasing the temperature to $30-35^{\circ} \mathrm{C}$. Below $5^{\circ} \mathrm{C}$, the signals of $\mathrm{Isa}^{-}$and those of its complexes appear separately (Fig. 23). The most remarkable changes are seen for the peak of H4 (splitting at low temperatures, displacement and line broadening at higher temperatures) indicating that the $\mathrm{C} 4-\mathrm{OH}$ group acts as a binding site. Because of the complexity of the ${ }^{1} \mathrm{H}$ NMR spectra and the overlap of the different peaks, it is not possible to unambiguously locate further binding sites in the ligand. 


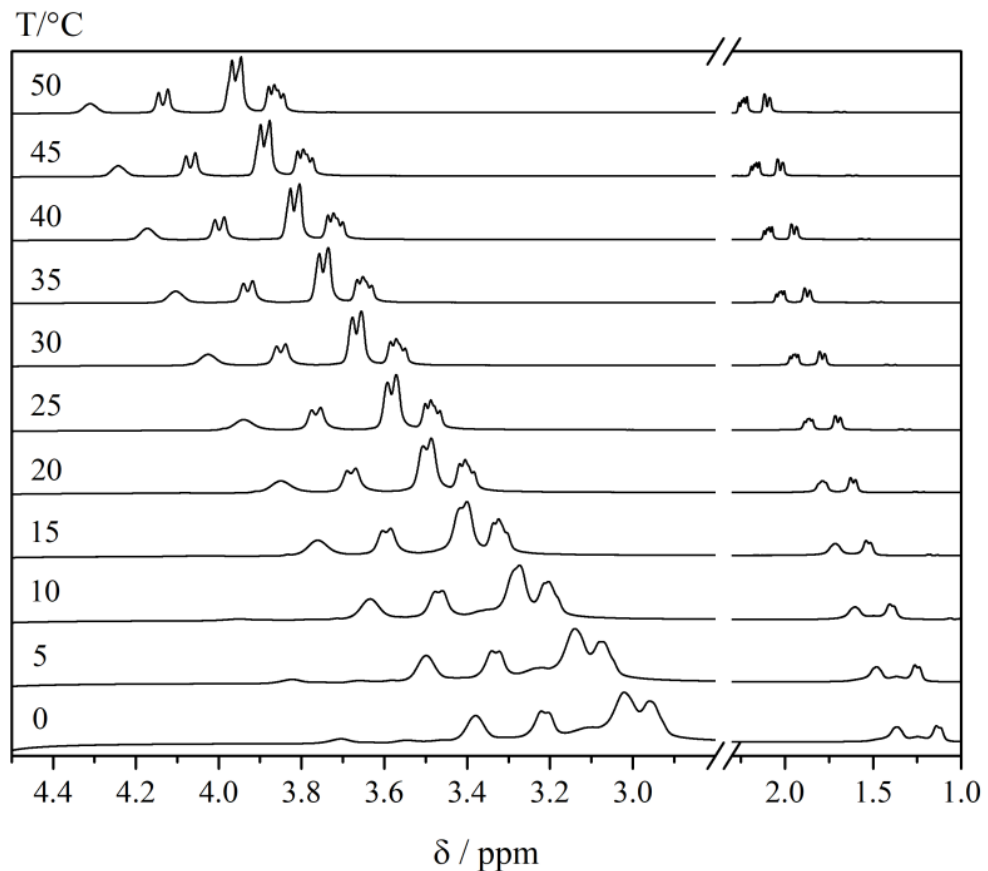

Figure 22. ${ }^{1} \mathrm{H}$ NMR spectra in the temperature range of $0-50{ }^{\circ} \mathrm{C}$ of a solution containing $\left[\mathrm{Isa}^{-}\right]_{\mathrm{T}}$ $=0.20 \mathrm{M},\left[\mathrm{OH}^{-}\right]_{\mathrm{T}}=0.20 \mathrm{M}$ and $\left[\mathrm{Ca}^{2+}\right]_{\mathrm{T}}=0.10 \mathrm{M}, \mathrm{I}=1.0 \mathrm{M}(\mathrm{NaCl})$.

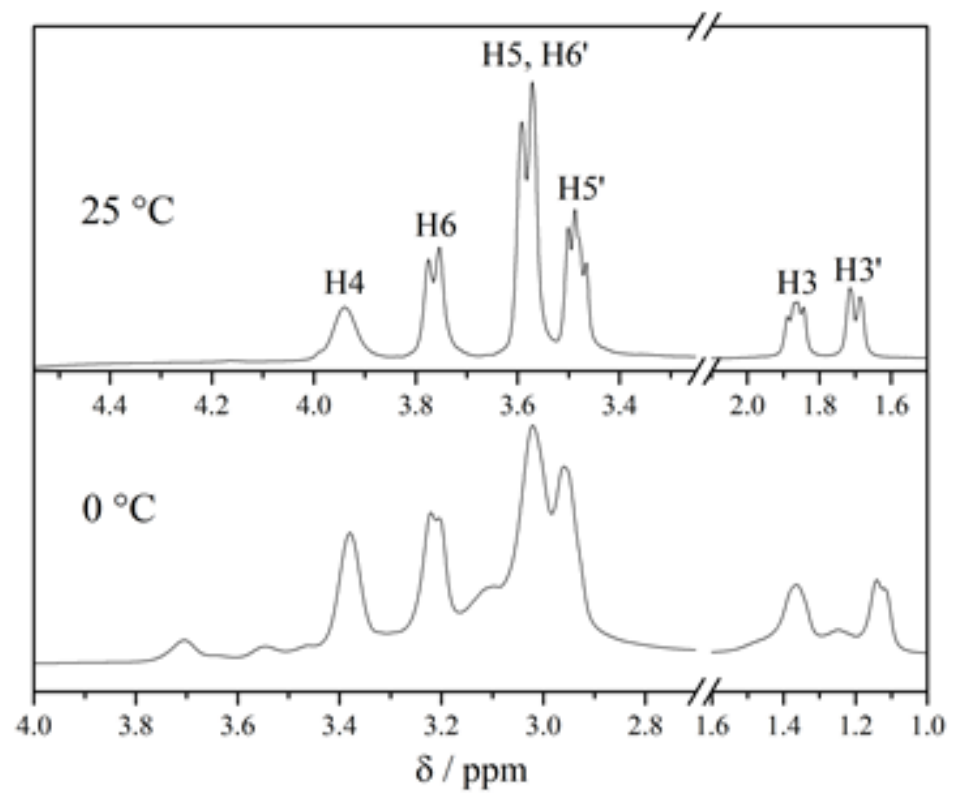

Figure 23. ${ }^{1} \mathrm{H}$ NMR spectra collected at $0{ }^{\circ} \mathrm{C}$ and $25{ }^{\circ} \mathrm{C}$ of a solution containing $\left[\mathrm{Isa}^{-}\right]_{\mathrm{T}}=0.20 \mathrm{M},\left[\mathrm{OH}^{-}\right]_{\mathrm{T}}=0.20 \mathrm{M}$ and $\left[\mathrm{Ca}^{2+}\right]_{\mathrm{T}}=0.10 \mathrm{M}, \mathrm{I}=1.0 \mathrm{M}(\mathrm{NaCl})$.

Upon increasing the concentration of $\mathrm{Ca}^{2+}$ in an alkaline Isa- ${ }^{-}$-containing solution, the ${ }^{13} \mathrm{C}$ NMR signals of $\mathrm{C} 1, \mathrm{C} 2$ and C3 significantly broaden (Fig. 24). At the highest calcium concentration the peaks of $\mathrm{C} 1$ and $\mathrm{C} 2$ broaden in such an extent that they practically vanish in the baseline. Additionally, a less spectacular, but still significant broadening is seen for the peak of C4. The signals of C5 and C6 seem to be less affected 
by the addition of calcium. These observations indicate that in alkaline medium Isa ${ }^{-}$acts as a multidentate ligand. The relatively large broadening of the signal of C3 suggests that the $\mathrm{OH}$ group(s) closer to the "tail" of the ligand is (are) possibly involved in the calcium binding.
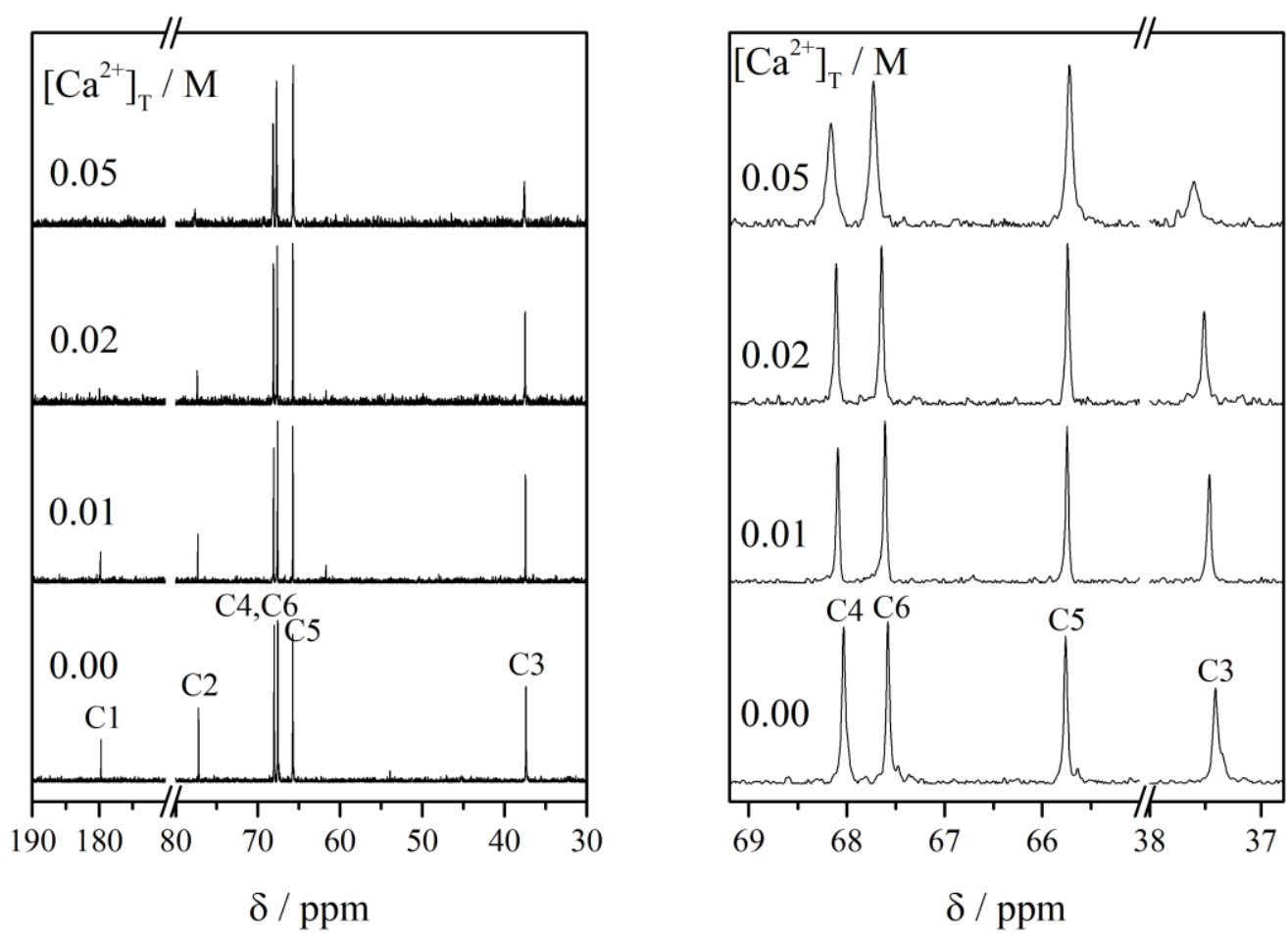

Figure 24. ${ }^{13} \mathrm{C}$ NMR spectra of solutions containing $\left[\mathrm{Isa}^{-}\right]_{\mathrm{T}}=0.20 \mathrm{M},\left[\mathrm{OH}^{-}\right]_{\mathrm{T}}=0.20 \mathrm{M}$ and $\left[\mathrm{Ca}^{2+}\right]_{\mathrm{T}}=0.00-0.05 \mathrm{M}, \mathrm{T}=(25 \pm 1)^{\circ} \mathrm{C}, \mathrm{I}=1.0 \mathrm{M}(\mathrm{NaCl})$.

The optimum geometry of the $\mathrm{CaIsaH}_{-1}{ }^{0}$ complex was determined by molecular modelling calculations, and the formation of four binding isomers can be suggested. In the two lowest energy bidentate arrangements, $\mathrm{Ca}^{2+}$ is bound to the $\mathrm{C} 2-\mathrm{O}^{-}$group (Fig. 25. a) or the $\mathrm{C}^{-}-\mathrm{O}^{-}$group (Fig. 25. b) beside one of the carboxylate oxygens, the latter is only $0.7 \mathrm{~kJ} \mathrm{~mol}^{-1}$ higher in energy than the former. Two other coordination isomers were also found with Isa ${ }^{-}$acting as tridentate ligand binding the $\mathrm{Ca}^{2+}$ ion via a carboxylate oxygen and the $\mathrm{C}^{-}-\mathrm{O}^{-}$and $\mathrm{C} 6-\mathrm{OH}$ groups (Fig. 25. c) or a carboxylate oxygen and the C4-OH and ${\mathrm{C} 6-\mathrm{O}^{-}}^{-}$groups (Fig. 25. d). The formation of these complexes is slightly less probable though, since their energies are 2.2 and $2.4 \mathrm{~kJ} \mathrm{~mol}^{-1}$ higher. The structure in which $\mathrm{Ca}^{2+}$ is bound to a carboxylate oxygen and the $\mathrm{C}^{-}-\mathrm{O}^{-}$was found to be one of the least energetically favoured ones, its energy being $14.9 \mathrm{~kJ} \mathrm{~mol}^{-1}$ higher than the most stable isomer. 


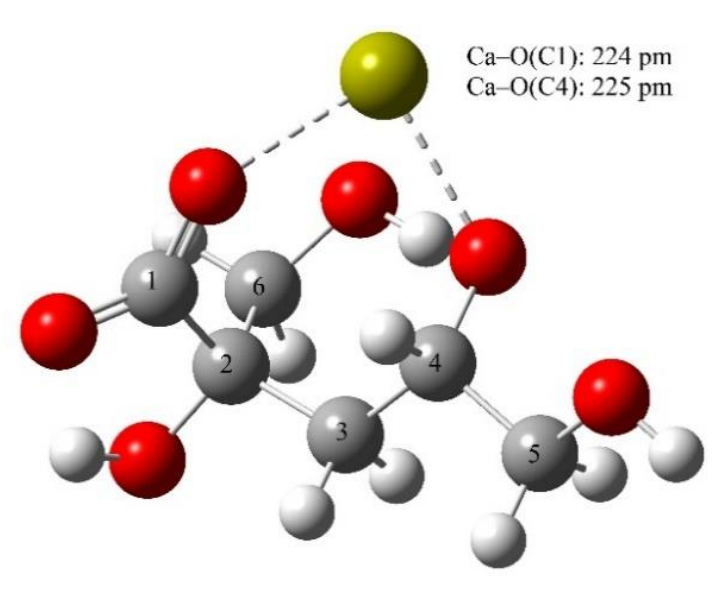

(a)

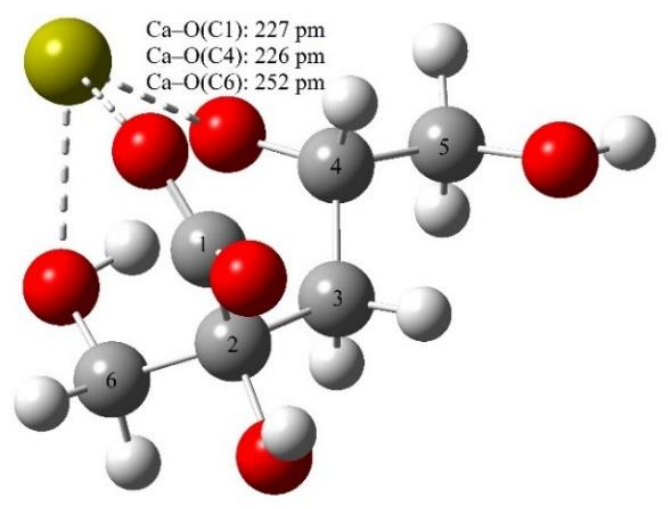

(c)

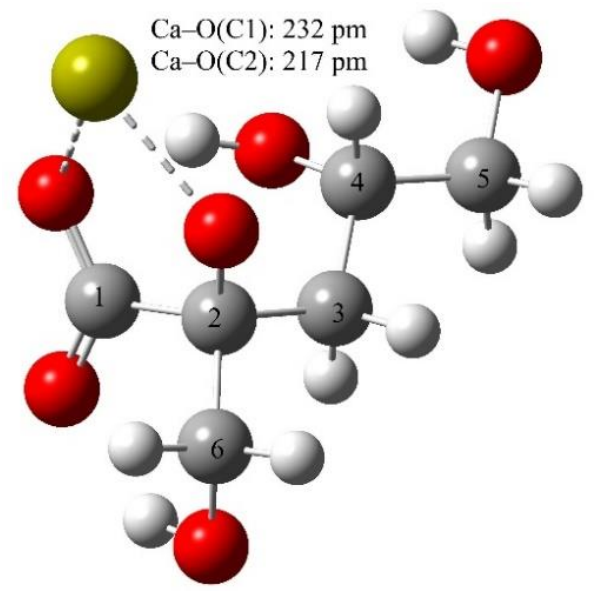

(b)

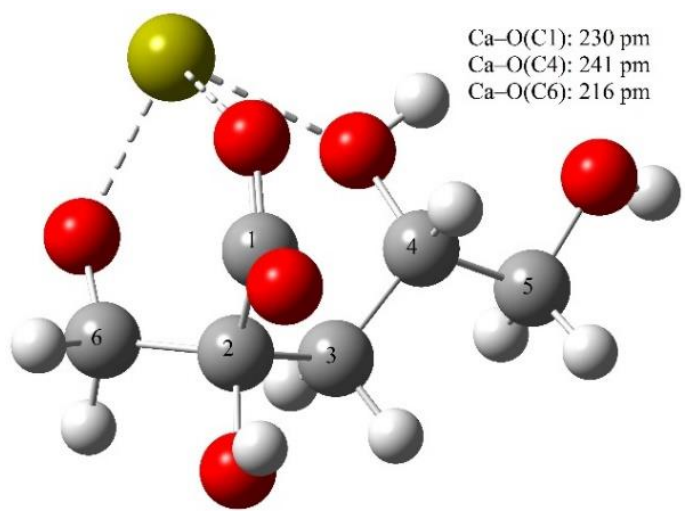

(d)

Figure 25. The optimum geometries calculated for $\mathrm{CaIsaH}_{-1}{ }^{0}$ at the B3LYP/6-31++G(d,p) level using the PCM model and explicit water molecules.

With regard to the $\mathrm{CaGlucH}_{-1}{ }^{0}$ complex, two coordination isomers were suggested, with the binding sites being a carboxylate oxygen and the $\mathrm{C}_{2}-\mathrm{O}^{-}$or the $\mathrm{C} 3-\mathrm{O}^{-}$ group, forming a five- or a six-membered chelate ring, respectively. ${ }^{[47]}$ In the polynuclear complexes present in the Gluc ${ }^{-}$-containing solutions (i.e. $\mathrm{Ca}_{2} \mathrm{GlucH}_{-3}{ }^{0}$ and $\mathrm{Ca}_{3} \mathrm{Gluc}_{2} \mathrm{H}_{-4}{ }^{0}$ ), the flexibility of $\mathrm{Gluc}^{-}$makes the simultaneous participation of $\mathrm{C}_{2}-\mathrm{O}^{-}$ and $\mathrm{C} 3-\mathrm{O}^{-}$in the $\mathrm{Ca}^{2+}$ ion binding possible (Fig. 26), i.e. $\mathrm{C} 2-\mathrm{O}^{-}$is bound to one of the $\mathrm{Ca}^{2+}$ ions and $\mathrm{C} 3-\mathrm{O}^{-}$is bound to the other. This feature was shown to be the prerequisite for the formation of polynuclear complexes. ${ }^{[47,62]}$ This condition does not stand for Isa ${ }^{-}$, it binds $\mathrm{Ca}^{2+}$ only with one alcoholate adjacent to the carboxylate (i.e. $\mathrm{C} 2-\mathrm{O}^{-}$). The participation of the other adjacent oxygen donor atom is hindered due to the unfavourable arrangement of the $\mathrm{COO}^{-}, \mathrm{C}_{2}-\mathrm{O}^{-}$and $\mathrm{C} 6-\mathrm{OH}$ groups. 

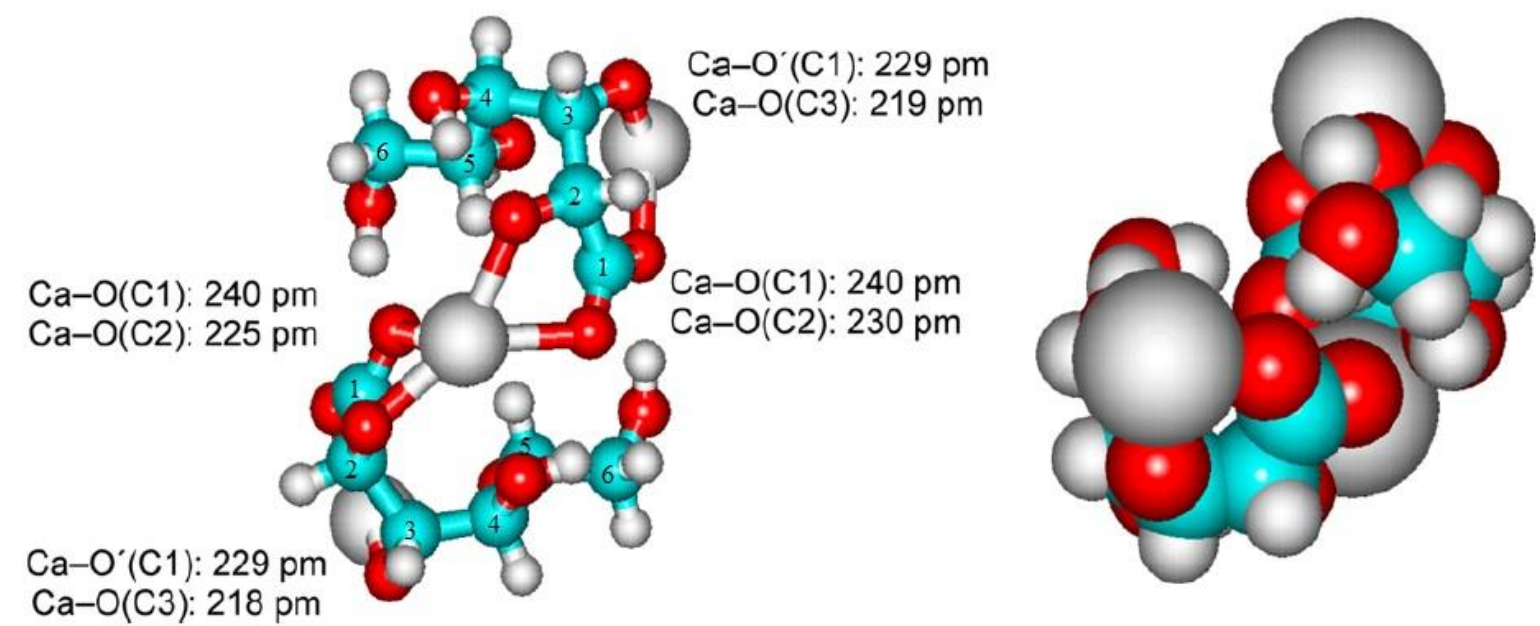

Figure 26. Optimum geometry of the $\mathrm{Ca}_{3} \mathrm{Gluc}_{2} \mathrm{H}_{4}{ }^{0}$ trinuclear complex applying ball-and-stick and spacefilling representation. This figure was taken from Ref. 47.

In view of these findings, $\mathrm{Isa}^{-}$and $\mathrm{Gluc}^{-}$are similar in the sense that both ligands bind $\mathrm{Ca}^{2+}$ ions in a multidentate manner. Profound differences are seen, however, in the binding sites of the ligands: $\mathrm{Gluc}^{-}$is able to bind two $\mathrm{Ca}^{2+}$ ions simultaneously via the alcoholate moieties adjacent to the carboxylate group, which makes the formation of polynuclear complexes possible. On the contrary, in Isa ${ }^{-}$, the position of the two oxygen donor groups adjacent to the carboxylate is unfavoured for the simultaneous calcium coordination. Because of this structural difference, Isa $^{-}$is not expected to behave identically to Gluc ${ }^{-}$in strongly alkaline solutions containing $\mathrm{Ca}^{2+}$ and actinides and/or lanthanides, i.e. under conditions relevant to L/ILW repositories. It can also be expected that the thermodynamics and structure of ternary complexes involving $\mathrm{Ca}^{2+}, \mathrm{L}^{-}$and radionuclides depend on whether $\mathrm{L}^{-}=\mathrm{Isa}^{-}$or Gluc ${ }^{-}$. According to Birjkumar, et al. "caution should be exercised when using gluconate as a thermodynamic model for isosaccharinate in uranyl(VI) chemistry". ${ }^{[10]}$ In that sense, this work led to similar conclusions with regard to certain aspects of the chemistry of aqueous solutions containing $\mathrm{Isa}^{-}$and $\mathrm{Ca}^{2+}$.

\subsection{Comparison of the crystal structure of calcium $\alpha$-D-isosaccharinate and calcium D-gluconate}

A crystal structure was determined for CaIsa 2 in 1968 by Norrestam, et al. ${ }^{[161]}$. Using a conventional laboratory instrument, weak diffraction from the small specimen limited the resolution of the structure to $0.97 \AA$, and precluded the use of anisotropic 
displacement parameters for all but the calcium ion. The data did not allow the location of the hydroxy hydrogen sites. The structure of $\mathrm{CaIsa}_{2}$ was shown to be orthorhombic with $P 2{ }_{1} 2{ }_{1} 2$ symmetry, the coordination polyhedron around the metal centre being a distorted Archimedean antiprism. The crystallographic details are collected in Table 4.

Table 4. Crystallographic details for CaIsa 2 determined by Norrestam et al. ${ }^{[161]}$

\begin{tabular}{ll}
\hline Lattice constants & $a=19.609(2) \AA$ \\
& $b=6.782(1) \AA$ \\
& $c=5.747(1) \AA$ \\
Cell volume & $764.3 \AA^{3}$ \\
Density & $1.418 \mathrm{~g} \mathrm{~cm}^{-3}$ \\
Molecules per unit & 2 \\
Space group & $P 2{ }_{1} 2{ }_{1} 2$ \\
\hline
\end{tabular}

Given its industrial and medical significance, it is somewhat surprising that a crystal structure has not previously been reported for calcium gluconate.

\subsubsection{Preparation of calcium $\alpha$-D-isosaccharinate and calcium D-gluconate single crystals}

In order to obtain single crystals of calcium isosaccharinate, several different techniques were tried. First, attempts were made to produce single crystals by slowly cooling a hot saturated solution of the salt. For this, a saturated solution was prepared at elevated temperatures (around $90-100^{\circ} \mathrm{C}$ ), this solution was placed into a glass vial, and the vial was placed into a Dewar flask (volume: $1 \mathrm{~L}$ ) filled with boiling water in order to slow down the cooling rate. In this set-up, the solution cooled to room temperature within a few hours, which proved to be too fast, the crystals obtained were too small. Similar experiments were conducted with the aid of a thermostate: a saturated solution was prepared at $50^{\circ} \mathrm{C}$, and this solution was then cooled to room temperature in 50 hours $\left(-1{ }^{\circ} \mathrm{C}\right.$ in every two hours). This experiment was also proved to be unsuccessful, the crystals obtained were too small for X-ray analysis. After that, alcohol diffusion experiments were conducted: $1 \mathrm{~mL}$ of saturated $\mathrm{CaIsa}_{2}$ solution was placed into a narrow glass vial and this vial was placed into a larger reservoir containing $5 \mathrm{~mL}$ of methanol/ethanol/propanol/2-propanol. In this set-up, the saturated aqueous solution came into contact with the alcohol through the vapour space. After several days, single crystals of approximately $0.4 \mathrm{~mm} \times 0.1 \mathrm{~mm} \times 0.1 \mathrm{~mm}$ dimensions were obtained from the methanol-containing system. 
For calcium gluconate, single crystal preparation was found to be more problematic. Slowly cooling a saturated solution produced very thin needle-like crystals ill-suited for $\mathrm{X}$-ray analysis regardless of using the "Dewar-flask technique" or slowly cooling the saturated solution down with the aid of a thermostate. Attempts were made to slowly evaporate a saturated solution, but this also proved to be unsuccessful. The alcohol diffusion technique, which was successful for $\mathrm{CaGluc}_{2}$, did not lead to success either. Accordingly, a systematic crystallization screening process was performed using the hanging drop vapour diffusion method in plates containing 24 wells with varying sample concentration, precipitant type and precipitant concentration. The sample concentration was varied between $10-100 \%$ by diluting a saturated solution of $\mathrm{CaIsa}_{2}$ with either water or the precipitant. The drop size varied between $4 \mu \mathrm{L}$ and $12 \mu \mathrm{L}$. Several aliphatic alcohols (methanol, ethanol, propanol, 2-propanol), ethylene glycol and $\mathrm{PEG}_{200}$ were tried as precipitants, either in pure form or diluted to $20-80 \%$ with water. The reservoir volume was $500 \mu \mathrm{L}$ or $1 \mathrm{~mL} .144$ different conditions were tried, and suitable crystals were grown from the one with an $8 \mu \mathrm{L}$ drop $\left(4 \mu \mathrm{L}\right.$ saturated $\mathrm{CaGluc}_{2}$ solution diluted with $4 \mu 1$ of $80 \%$ ethylene glycol) over $1 \mathrm{~mL}$ of $80 \%$ ethylene glycol. Crystals were visible after several days, and grew to approximately $0.05 \mathrm{~mm} \times 0.02 \mathrm{~mm} \times 0.01 \mathrm{~mm}$.

\subsubsection{Crystal structure of calcium $\alpha$-D-isosaccharinate}

The asymmetric unit of calcium isosaccharinate contains half of a $\mathrm{CaIsa}_{2}$ with the metal ion located on the two fold axis of $P 2{ }_{1} 2{ }_{1} 2$. As Norrestam, et al. observed, ${ }^{[161]}$ with eight metal bound oxygen atoms, the coordination polyhedron of the CaIsa 2 crystal structure is that of a distorted Archimedean antiprism (Fig. 27). Underpinning the coordination polymer, in the single crystal structure the ligand binds two calcium ions, with one metal bound to a carboxylate oxygen $(\mathrm{O} 1)$ and $\mathrm{C} 2-\mathrm{OH}(\mathrm{O} 2)$, and the second bound to $\mathrm{C} 4-\mathrm{OH}(\mathrm{O} 4)$ and $\mathrm{C} 5-\mathrm{OH}(\mathrm{O} 5)$ (Fig. 28). The $\mathrm{C} 6-\mathrm{OH}$ and the other carboxylate oxygen do not participate in metal binding. In contrast, the molecular modelling calculations suggest that in aqueous solutions Isa ${ }^{-}$binds calcium using either the oxy triad O1-O4-O6 or that of O1-O2-O6 (Fig. 11 on page 28). Selected geometry details are collected in Tables 5. and 6.

Extended hydrogen bonding network was found to be present in the structure. While $\mathrm{C} 4-\mathrm{OH}$ participates in an intrachain hydrogen bonding interaction, the rest of the oxygen 
atoms participates in interchain hydrogen bonding interactions establishing a threedimensional network.

Crystallographic details obtained for CaIsa 2 are provided in Table 9. on page 49.

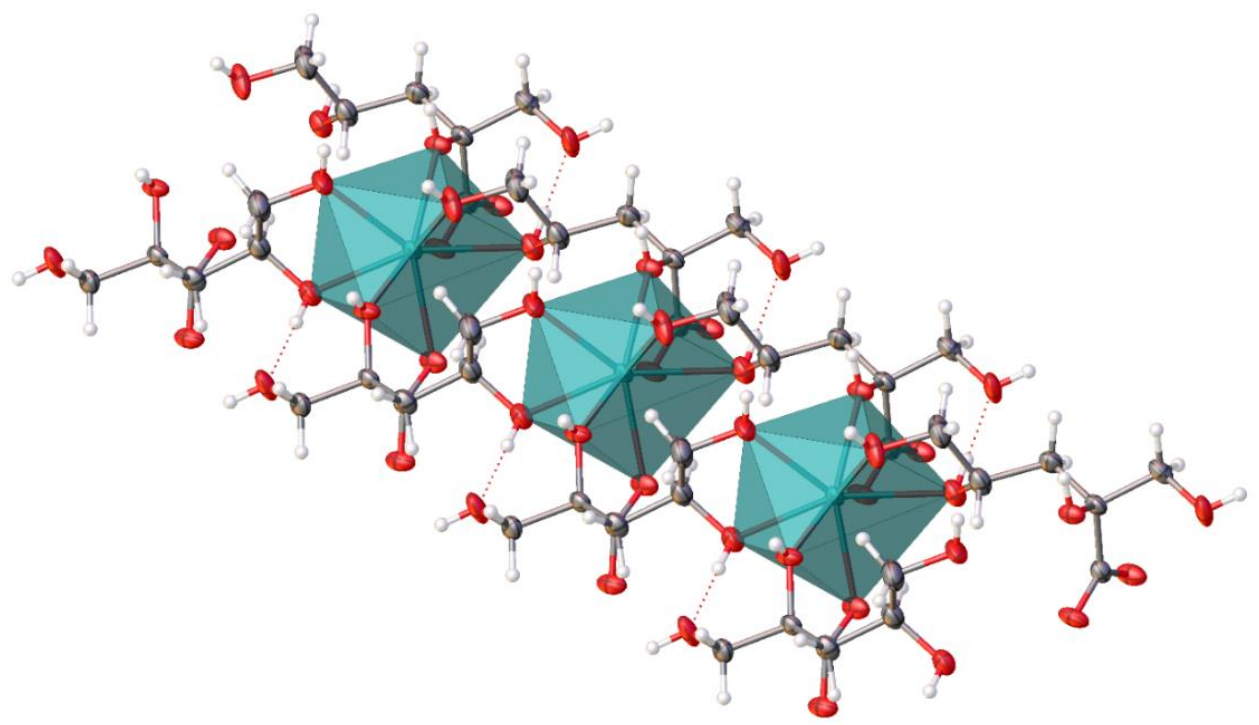

Figure 27. Trinuclear segment of a coordination polymer in the $100 \mathrm{~K}$ single crystal structure of $\mathrm{CaIsa}_{2}$, showing the distorted Archimedean antiprisms defined by the oxygen coordination of the calcium ions. The distance between adjacent metal centres is 6.7573(4) $\AA$ (equal to the length of the $a$ axis).

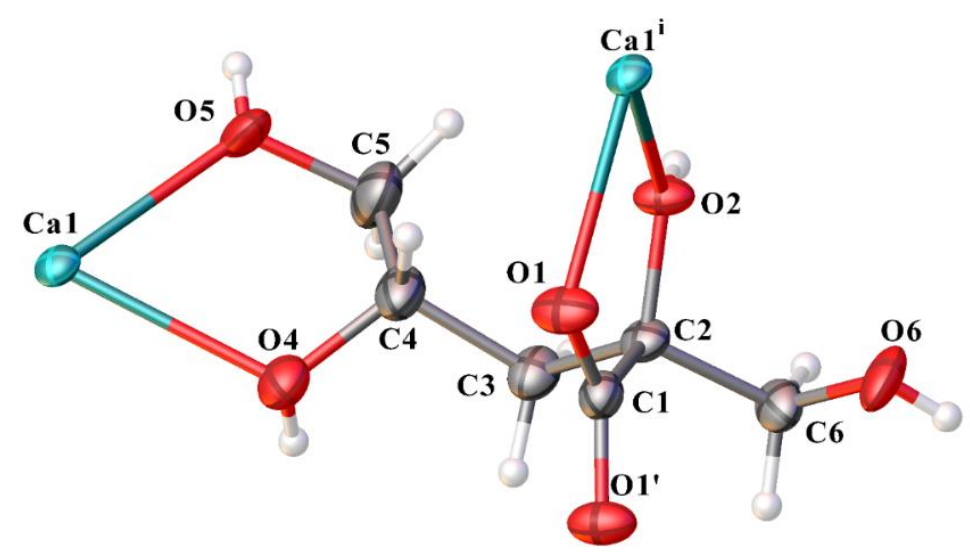

Figure 28. The asymmetric unit atoms and metal binding sites in the $100 \mathrm{~K}$ single crystal structure of $\mathrm{CaIsa}_{2}$, with displacement ellipsoids at the $90 \%$ level. The superscript $\mathrm{i}$ denotes the operation $\mathrm{x}+1, \mathrm{y}, \mathrm{z}$.

Table 5. Selected distances for $\mathrm{CaIsa}_{2}(\AA)$.

\begin{tabular}{llllll}
\hline Atom & Atom & Distance & Atom & Atom & Distance \\
\hline $\mathrm{Ca}(1)$ & $\mathrm{O}(1)^{\mathrm{i}}$ & $2.382(2)$ & $\mathrm{Ca}(1)$ & $\mathrm{O}(1)^{\mathrm{ii}}$ & $2.382(2)$ \\
$\mathrm{Ca}(1)$ & $\mathrm{O}(5)^{\mathrm{iii}}$ & $2.383(2)$ & $\mathrm{Ca}(1)$ & $\mathrm{O}(5)$ & $2.383(2)$ \\
$\mathrm{Ca}(1)$ & $\mathrm{O}(2)^{\mathrm{ii}}$ & $2.435(2)$ & $\mathrm{Ca}(1)$ & $\mathrm{O}(2)^{\mathrm{i}}$ & $2.435(2)$ \\
$\mathrm{Ca}(1)$ & $\mathrm{O}(4)^{\mathrm{iii}}$ & $2.512(2)$ & $\mathrm{Ca}(1)$ & $\mathrm{O}(4)$ & $2.512(2)$ \\
\hline
\end{tabular}

${ }^{\mathrm{i}} 1-\mathrm{x},-\mathrm{y},+\mathrm{z} ;{ }^{\mathrm{ii}} \mathrm{x}-1, \mathrm{y}, \mathrm{z} ;{ }^{\mathrm{iii}}-\mathrm{x},-\mathrm{y}, \mathrm{z}$ 
Table 6. Selected bond angles for $\mathrm{CaIsa}_{2}\left({ }^{\circ}\right)$.

\begin{tabular}{cccccccc}
\hline Atom & Atom & Atom & Angle & Atom & Atom & Atom & Angle \\
\hline $\mathrm{O}\left(1^{\mathrm{i}}\right.$ & $\mathrm{Ca}(1)$ & $\mathrm{O}(1)^{\mathrm{ii}}$ & $86.7(1)$ & $\mathrm{O}(2)^{\mathrm{i}}$ & $\mathrm{Ca}(1)$ & $\mathrm{O}(4)^{\mathrm{iii}}$ & $111.90(6)$ \\
$\mathrm{O}(1)^{\mathrm{i}}$ & $\mathrm{Ca}(1)$ & $\mathrm{O}(2)^{\mathrm{i}}$ & $64.97(7)$ & $\mathrm{O}(2)^{\mathrm{i}}$ & $\mathrm{Ca}(1)$ & $\mathrm{O}(4)$ & $76.71(6)$ \\
$\mathrm{O}(1)^{\mathrm{i}}$ & $\mathrm{Ca}(1)$ & $\mathrm{O}(2)^{\mathrm{ii}}$ & $146.76(7)$ & $\mathrm{O}(2)^{\mathrm{i}}$ & $\mathrm{Ca}(1)$ & $\mathrm{O}(5)^{\mathrm{iii}}$ & $72.66(7)$ \\
$\mathrm{O}(1)^{\mathrm{i}}$ & $\mathrm{Ca}(1)$ & $\mathrm{O}(4)$ & $78.06(7)$ & $\mathrm{O}(2)^{\mathrm{i}}$ & $\mathrm{Ca}(1)$ & $\mathrm{O}(5)$ & $82.84(7)$ \\
$\mathrm{O}(1)^{\mathrm{i}}$ & $\mathrm{Ca}(1)$ & $\mathrm{O}(4)^{\mathrm{iii}}$ & $80.84(7)$ & $\mathrm{O}(2)^{\mathrm{ii}}$ & $\mathrm{Ca}(1)$ & $\mathrm{O}(4)$ & $111.90(6)$ \\
$\mathrm{O}(1)^{\mathrm{i}}$ & $\mathrm{Ca}(1)$ & $\mathrm{O}(5)$ & $137.08(6)$ & $\mathrm{O}(2)^{\mathrm{ii}}$ & $\mathrm{Ca}(1)$ & $\mathrm{O}(4)^{\mathrm{iii}}$ & $76.71(6)$ \\
$\mathrm{O}(1)^{\mathrm{i}}$ & $\mathrm{Ca}(1)$ & $\mathrm{O}(5)^{\mathrm{iii}}$ & $110.44(7)$ & $\mathrm{O}(2)^{\mathrm{ii}}$ & $\mathrm{Ca}(1)$ & $\mathrm{O}(5)^{\mathrm{iii}}$ & $82.84(7)$ \\
$\mathrm{O}(1)^{\mathrm{ii}}$ & $\mathrm{Ca}(1)$ & $\mathrm{O}(2)^{\mathrm{ii}}$ & $64.97(7)$ & $\mathrm{O}(2)^{\mathrm{ii}}$ & $\mathrm{Ca}(1)$ & $\mathrm{O}(5)$ & $72.66(7)$ \\
$\mathrm{O}(1)^{\mathrm{ii}}$ & $\mathrm{Ca}(1)$ & $\mathrm{O}(4)$ & $80.84(7)$ & $\mathrm{O}(4)$ & $\mathrm{Ca}(1)$ & $\mathrm{O}(4)^{\mathrm{iii}}$ & $150.8(1)$ \\
$\mathrm{O}(1)^{\mathrm{ii}}$ & $\mathrm{Ca}(1)$ & $\mathrm{O}(4)^{\mathrm{iii}}$ & $78.06(7)$ & $\mathrm{O}(4)$ & $\mathrm{Ca}(1)$ & $\mathrm{O}(5)$ & $67.00(7)$ \\
$\mathrm{O}(1)^{\mathrm{ii}}$ & $\mathrm{Ca}(1)$ & $\mathrm{O}(5)$ & $110.44(7)$ & $\mathrm{O}(4)$ & $\mathrm{Ca}(1)$ & $\mathrm{O}(5)^{\mathrm{iii}}$ & $139.92(7)$ \\
$\mathrm{O}(1)^{\mathrm{ii}}$ & $\mathrm{Ca}(1)$ & $\mathrm{O}(5)^{\mathrm{iii}}$ & $137.08(6)$ & $\mathrm{O}(5)$ & $\mathrm{Ca}(1)$ & $\mathrm{O}(5)^{\mathrm{iii}}$ & $83.9(1)$ \\
$\mathrm{O}(2)^{\mathrm{i}}$ & $\mathrm{Ca}(1)$ & $\mathrm{O}(2)^{\mathrm{ii}}$ & $147.0(1)$ & & & & \\
\hline $\mathrm{i} \mathrm{x}-1, \mathrm{y}, \mathrm{z} ;{ }^{\mathrm{ii}} 1-\mathrm{x},-\mathrm{y}, \mathrm{z} ;{ }^{\mathrm{iii}}-\mathrm{x},-\mathrm{y}, \mathrm{z}$ & & & & &
\end{tabular}

\subsubsection{Crystal structure of calcium D-gluconate}

The asymmetric unit of the calcium gluconate structure contains a $\mathrm{CaGluc}_{2}$ unit together with a water solvate molecule (Fig. 29). The structure is orthorhombic with non-centrosymmetric P $2{ }_{1}{ }_{2} 2_{1}$ symmetry and is comprised of one-dimensional coordination polymers parallel to the $a$ axis (Fig. 30). Both a carboxylate oxygen (O1_1) ${ }^{3}$ of one of the crystallographically unique gluconate ligands (hereafter referred to as Gluc1) and $\mathrm{C} 2-\mathrm{OH}\left(\mathrm{O} 2 \_2\right)$ of the second crystallographically unique gluconate ligand (hereafter referred to as Gluc2) bridge the calcium ion of the asymmetric unit and an adjacent symmetry related calcium ion (Fig. 31). There is a third $\mu$-oxo bridge, being provided by the carboxylate oxygen $(\mathrm{O} 1)$ of a gluconate related by symmetry to Gluc2 by a screw axis in the $a$ direction. The distance between adjacent metal centres within a polymer is $3.7312(2) \AA$. This structure is notably distinguished from that of CaIsa2, in which there are no $\mu$-oxo bridges, and the intrachain calcium to calcium distance is much longer (6.7573(4), that is) than the 3.7312(2) $\AA$ found in the structure of $\mathrm{CaGluc}_{2} \cdot \mathrm{H}_{2} \mathrm{O}$.

The calcium ion coordination polyhedron is that of a distorted triaugmented triangular prism, and, as Fig. 30 suggests, adjoining polyhedral of a given polynuclear chain share a triangular face. The calcium ion is coordinated to nine oxygen atoms, five

\footnotetext{
${ }^{3}$ Hereafter, in OX_Y, X denotes the number of the carbon atom to which the oxygen is attached in the ligand and $\mathrm{Y}=1$ for Gluc1 or 2 for Gluc2, e.g. O3_1 stands for the $\mathrm{C} 3-\mathrm{OH}$ oxygen donor atom in Gluc1.
} 
of which are from the two gluconate ligands of the asymmetric unit. Three of the asymmetric unit donors are hydroxy oxygens of Gluc2 (O2_2, O3_2, O4_2), while the other two are a carboxylate oxygen $\left(\mathrm{O} 1 \_1\right)$ and a hydroxy oxygen $\left(\mathrm{O} 2 \_1\right)$ of Gluc1. While neither of the carboxylate oxygens of Gluc2 coordinate to the calcium ion of the asymmetric unit, the O1_2 coordinates with the adjacent calcium that is bridged by O1_1. The 01_2 oxygen additionally bridges to the next calcium in the chain and, remarkably, this ligand then binds to three adjacent metal centres (Fig. 32). Selected geometry details are collected in Tables 7 and 8.

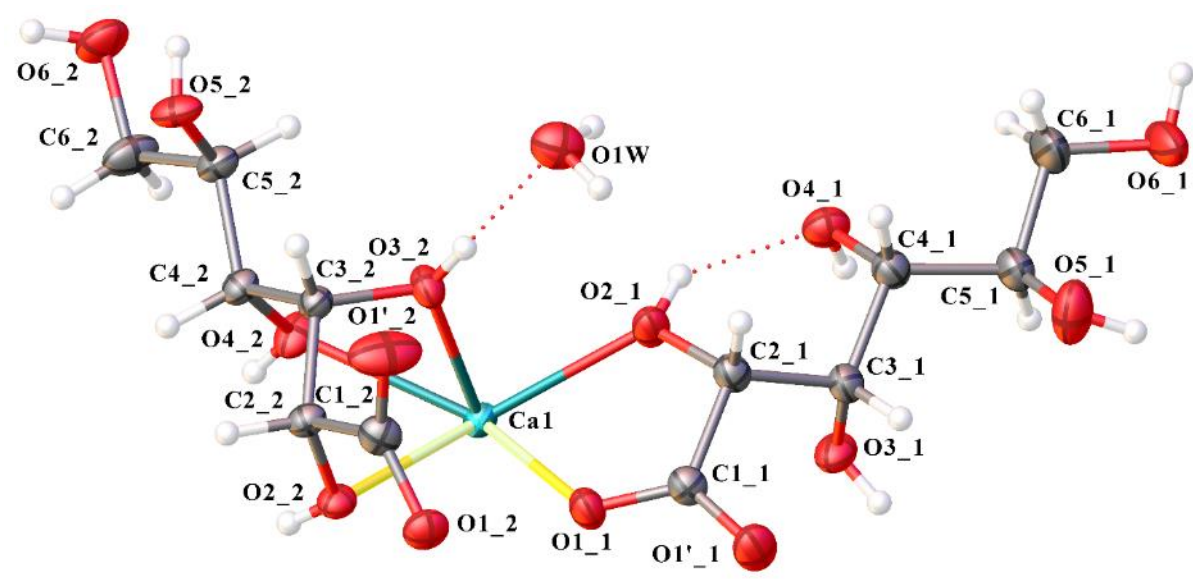

Figure 29. The asymmetric unit of the single crystal structure of $\mathrm{CaGluc}_{2} \cdot \mathrm{H}_{2} \mathrm{O}$ (at $100 \mathrm{~K}$ ) with displacement ellipsoids shown at the $95 \%$ level and bridging bonds highlighted.

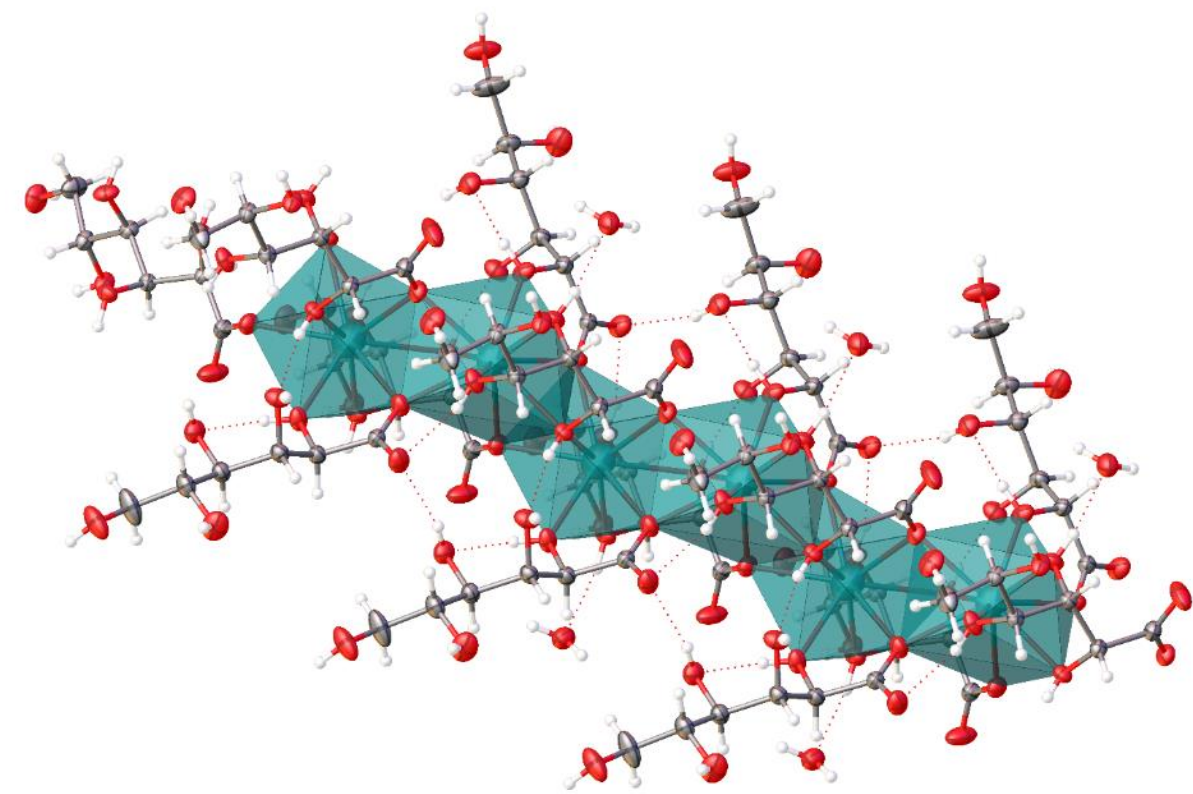

Figure 30. A hexanuclear segment of a coordination polymer in the $100 \mathrm{~K}$ single crystal structure of $\mathrm{CaGluc}_{2} \cdot \mathrm{H}_{2} \mathrm{O}$ showing the face sharing distorted triaugmented triangular prismshaped coordination polyhedra. The distance between adjacent metal centres within a polymer is $3.7312(2) \AA$. The displacement ellipsoids of the calcium ion have been enlarged for emphasis. 


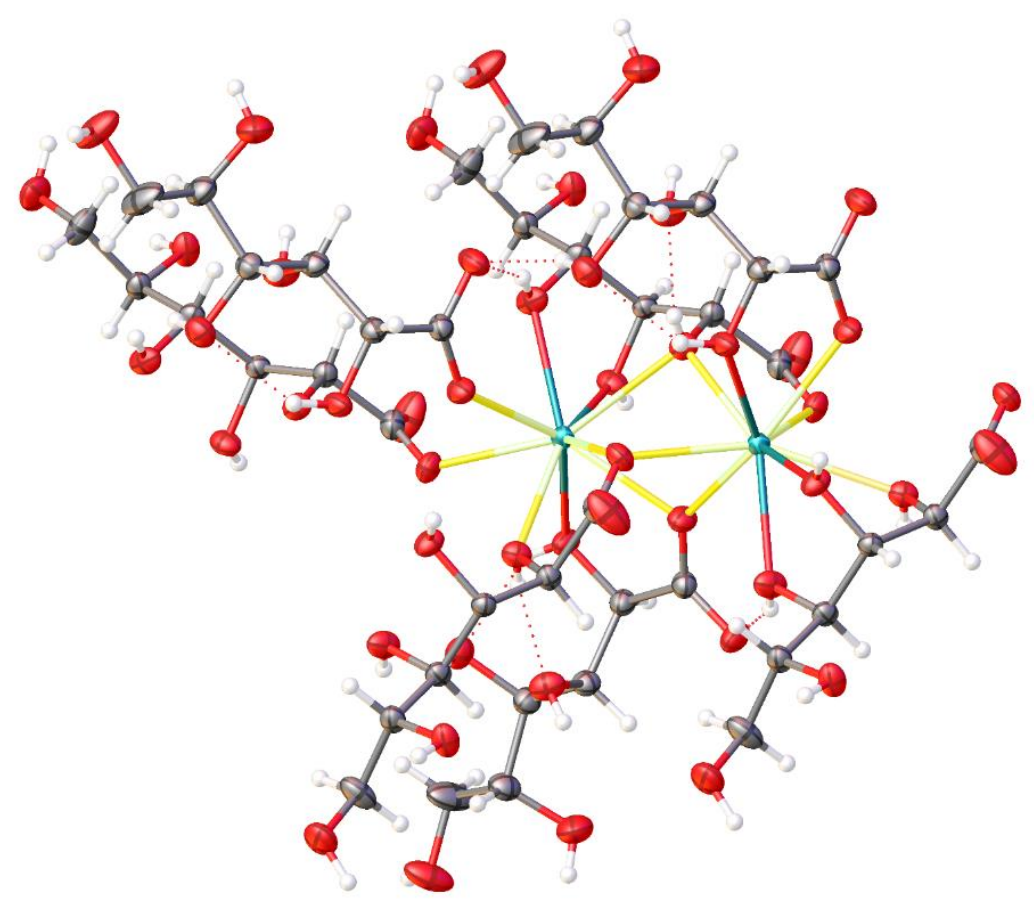

Figure 31. A dinuclear segment of a polynuclear chain in the $100 \mathrm{~K}$ single crystal structure of $\mathrm{CaGluc}_{2} \cdot \mathrm{H}_{2} \mathrm{O}$ with the bridging bonds highlighted. The distance between the metal centres is 3.7312(2) A. The displacement ellipsoids are shown at the 95\% level.

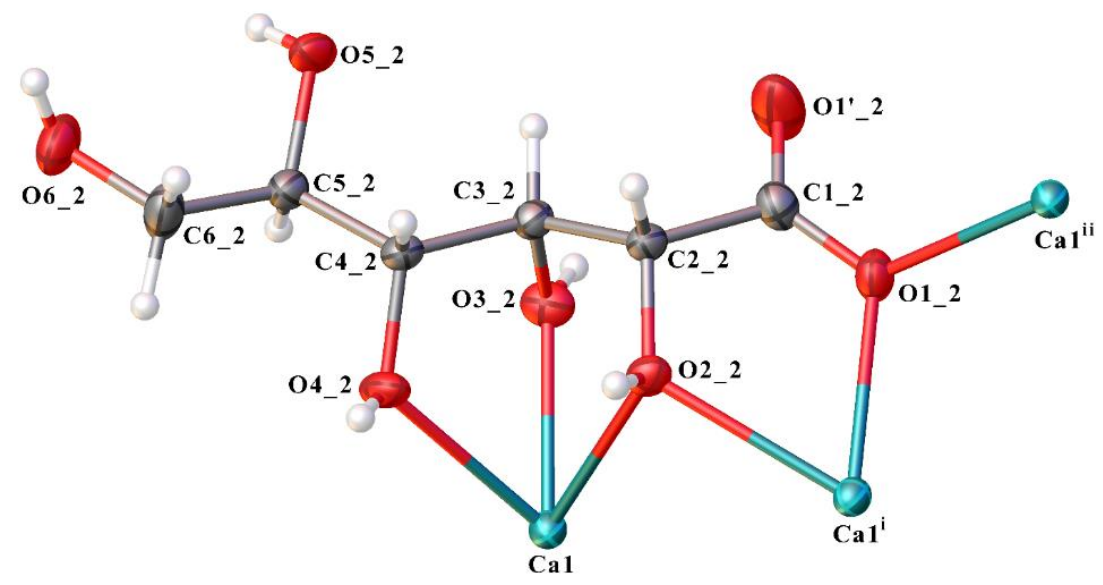

Figure 32. The metal binding sites of ligand 2 in the 100 Kelvin single crystal structure of $\mathrm{CaGluc}_{2} \cdot \mathrm{H}_{2} \mathrm{O}$, with displacement ellipsoids at the $95 \%$ level. The superscript $\mathrm{i}$ denotes the operation $\mathrm{x}-0.5,0.5-\mathrm{y}, 1-\mathrm{z}$ and the superscript ii $\mathrm{x}-1, \mathrm{y}, \mathrm{z}$.

Table 7. Selected distances for $\mathrm{CaGluc}_{2} \cdot \mathrm{H}_{2} \mathrm{O}(\AA)$.

\begin{tabular}{cccccc}
\hline Atom & Atom & Distance & Atom & Atom & Distance \\
\hline $\mathrm{Ca}(1)$ & $\mathrm{O}\left(3 \_2\right)$ & $2.4123(7)$ & $\mathrm{Ca}(1)$ & $\mathrm{O}\left(2 \_1\right)$ & $2.4370(8)$ \\
$\mathrm{Ca}(1)$ & $\mathrm{O}\left(4 \_2\right)$ & $2.4467(7)$ & $\mathrm{Ca}(1)$ & $\mathrm{O}\left(2 \_2\right)^{\mathrm{i}}$ & $2.4476(7)$ \\
$\mathrm{Ca}(1)$ & $\mathrm{O}\left(1 \_2\right)^{\mathrm{i}}$ & $2.4661(8)$ & $\mathrm{Ca}(1)$ & $\mathrm{O}\left(1 \_2\right)^{\mathrm{ii}}$ & $2.4739(7)$ \\
$\mathrm{Ca}(1)$ & $\mathrm{O}\left(1 \_1\right)$ & $2.4837(7)$ & $\mathrm{Ca}(1)$ & $\mathrm{O}\left(1 \_1\right)^{\mathrm{i}}$ & $2.5023(7)$ \\
$\mathrm{Ca}(1)$ & $\mathrm{O}\left(2 \_2\right)$ & $2.6291(7)$ & $\mathrm{Ca}(1)$ & $\mathrm{Ca}(1)^{\mathrm{iii}}$ & $3.7312(2)$ \\
\hline${ }^{\mathrm{i}} \mathrm{x}+1 / 2,1 / 2-\mathrm{y}, 1-\mathrm{z} ;{ }^{\mathrm{ii}} 1+\mathrm{x}, \mathrm{y}, \mathrm{z} ;{ }^{\mathrm{iii}} \mathrm{x}-1 / 2,1 / 2-\mathrm{y},-\mathrm{z}$ & & &
\end{tabular}


Table 8. Selected bond angles for $\mathrm{CaGluc}_{2} \cdot \mathrm{H}_{2} \mathrm{O}\left({ }^{\circ}\right)$.

\begin{tabular}{|c|c|c|c|c|c|c|c|}
\hline Atom & Atom & Atom & Angle & Atom & Atom & Atom & Angle \\
\hline $\mathrm{Ca}(1)^{\mathrm{i}}$ & $\mathrm{Ca}(1)$ & $\mathrm{Ca}(1)^{\mathrm{ii}}$ & $128.166(9)$ & $\mathrm{Ca}(1)^{\mathrm{ii}}$ & $\mathrm{O}\left(1 \_2\right)$ & $\mathrm{Ca}(1)^{\mathrm{iii}}$ & $98.10(3)$ \\
\hline $\mathrm{Ca}(1)$ & $\mathrm{O}\left(1 \_1\right)$ & $\mathrm{Ca}(1)^{\mathrm{ii}}$ & $96.90(2)$ & $\mathrm{Ca}(1)^{\mathrm{ii}}$ & $\mathrm{O}\left(2 \_2\right)$ & $\mathrm{Ca}(1)$ & $94.54(2)$ \\
\hline $\mathrm{O}\left(1 \_1\right)$ & $\mathrm{Ca}(1)$ & $\mathrm{O}\left(1 \_1\right)^{\mathrm{i}}$ & 141.31(1) & $\mathrm{O}\left(1 \_2\right)^{\mathrm{iv}}$ & $\mathrm{Ca}(1)$ & $\mathrm{O}\left(3 \_2\right)$ & $98.18(2)$ \\
\hline $\mathrm{O}\left(1 \_1\right)$ & $\mathrm{Ca}(1)$ & $\mathrm{O}\left(1 \_2\right)^{\mathrm{i}}$ & $68.22(2)$ & $\mathrm{O}\left(1 \_2\right)^{\mathrm{iv}}$ & $\mathrm{Ca}(1)$ & $\mathrm{O}\left(4 \_2\right)$ & $86.78(3)$ \\
\hline $\mathrm{O}\left(1 \_1\right)$ & $\mathrm{Ca}(1)$ & $\mathrm{O}\left(1 \_2\right)^{\mathrm{iv}}$ & $129.70(2)$ & $\mathrm{O}\left(1 \_2\right)^{\mathrm{i}}$ & $\mathrm{Ca}(1)$ & $\mathrm{O}\left(1 \_2\right)^{\mathrm{iv}}$ & $128.78(2)$ \\
\hline $\mathrm{O}\left(1 \_1\right)$ & $\mathrm{Ca}(1)$ & $\mathrm{O}\left(2 \_1\right)$ & $62.67(2)$ & $\mathrm{O}\left(1 \_2\right)^{\mathrm{i}}$ & $\mathrm{Ca}(1)$ & $\mathrm{O}\left(2 \_1\right)$ & $120.28(2)$ \\
\hline $\mathrm{O}\left(1 \_1\right)$ & $\mathrm{Ca}(1)$ & $\mathrm{O}\left(2 \_2\right)$ & $71.74(2)$ & $\mathrm{O}\left(1 \_2\right)^{\mathrm{i}}$ & $\mathrm{Ca}(1)$ & $\mathrm{O}\left(2 \_2\right)$ & $68.63(2)$ \\
\hline $\mathrm{O}\left(1 \_1\right)$ & $\mathrm{Ca}(1)$ & $\mathrm{O}\left(2 \_2\right)^{\mathrm{i}}$ & $79.90(2)$ & $\mathrm{O}\left(1 \_2\right)^{\mathrm{i}}$ & $\mathrm{Ca}(1)$ & $\mathrm{O}\left(2 \_2\right)^{\mathrm{i}}$ & $65.52(2)$ \\
\hline $\mathrm{O}\left(1 \_1\right)$ & $\mathrm{Ca}(1)$ & $\mathrm{O}\left(3 \_2\right)$ & 83.94(2) & $\mathrm{O}\left(1 \_2\right)^{\mathrm{i}}$ & $\mathrm{Ca}(1)$ & $\mathrm{O}\left(3 \_2\right)$ & $133.01(2)$ \\
\hline $\mathrm{O}\left(1 \_1\right)$ & $\mathrm{Ca}(1)$ & $\mathrm{O}\left(4 \_2\right)$ & $135.16(3)$ & $\mathrm{O}\left(1 \_2\right)^{\mathrm{i}}$ & $\mathrm{Ca}(1)$ & $\mathrm{O}\left(4 \_2\right)$ & $112.12(3)$ \\
\hline $\mathrm{O}\left(1 \_1\right)^{\mathrm{i}}$ & $\mathrm{Ca}(1)$ & $\mathrm{O}\left(1 \_2\right)^{\mathrm{i}}$ & $74.88(2)$ & $\mathrm{O}\left(2 \_1\right)$ & $\mathrm{Ca}(1)$ & $\mathrm{O}\left(2 \_2\right)$ & $121.08(2)$ \\
\hline $\mathrm{O}\left(1 \_1\right)^{\mathrm{i}}$ & $\mathrm{Ca}(1)$ & $\mathrm{O}\left(1 \_2\right)^{\mathrm{iv}}$ & $67.80(2)$ & $\mathrm{O}\left(2 \_1\right)$ & $\mathrm{Ca}(1)$ & $\mathrm{O}\left(2 \_2\right)^{\mathrm{i}}$ & $74.18(3)$ \\
\hline $\mathrm{O}\left(1 \_1\right)^{\mathrm{i}}$ & $\mathrm{Ca}(1)$ & $\mathrm{O}\left(2 \_1\right)$ & $133.45(3)$ & $\mathrm{O}\left(2 \_1\right)$ & $\mathrm{Ca}(1)$ & $\mathrm{O}\left(3 \_2\right)$ & $72.83(3)$ \\
\hline $\mathrm{O}\left(1 \_1\right)^{\mathrm{i}}$ & $\mathrm{Ca}(1)$ & $\mathrm{O}\left(2 \_2\right)$ & $105.47(2)$ & $\mathrm{O}\left(2 \_1\right)$ & $\mathrm{Ca}(1)$ & $\mathrm{O}\left(4 \_2\right)$ & $126.29(2)$ \\
\hline $\mathrm{O}\left(1 \_1\right)^{\mathrm{i}}$ & $\mathrm{Ca}(1)$ & $\mathrm{O}\left(3 \_2\right)$ & $131.76(2)$ & $\mathrm{O}\left(2 \_2\right)$ & $\mathrm{Ca}(1)$ & $\mathrm{O}\left(3 \_2\right)$ & $66.97(2)$ \\
\hline $\mathrm{O}\left(1 \_1\right)^{\mathrm{i}}$ & $\mathrm{Ca}(1)$ & $\mathrm{O}\left(2 \_2\right)^{\mathrm{i}}$ & $74.55(2)$ & $\mathrm{O}\left(2 \_2\right)$ & $\mathrm{Ca}(1)$ & $\mathrm{O}\left(4 \_2\right)$ & $67.79(2)$ \\
\hline $\mathrm{O}\left(1 \_1\right)^{\mathrm{i}}$ & $\mathrm{Ca}(1)$ & $\mathrm{O}\left(4 \_2\right)$ & $69.92(2)$ & $\mathrm{O}\left(2 \_2\right)^{\mathrm{i}}$ & $\mathrm{Ca}(1)$ & $\mathrm{O}\left(2 \_2\right)$ & $132.35(2)$ \\
\hline $\mathrm{O}\left(1 \_2\right)^{\mathrm{iv}}$ & $\mathrm{Ca}(1)$ & $\mathrm{O}\left(2 \_1\right)$ & $70.05(2)$ & $\mathrm{O}\left(2 \_2\right)^{\mathrm{i}}$ & $\mathrm{Ca}(1)$ & $\mathrm{O}\left(3 \_2\right)$ & $146.98(3)$ \\
\hline $\mathrm{O}\left(1 \_2\right)^{\mathrm{iv}}$ & $\mathrm{Ca}(1)$ & $\mathrm{O}\left(2 \_2\right)$ & $154.17(2)$ & $\mathrm{O}\left(2 \_2\right)^{\mathrm{i}}$ & $\mathrm{Ca}(1)$ & $\mathrm{O}\left(4 \_2\right)$ & $143.34(3)$ \\
\hline $\mathrm{O}\left(1 \_2\right)^{\mathrm{ivv}}$ & $\mathrm{Ca}(1)$ & $\mathrm{O}\left(2 \_2\right)^{\mathrm{i}}$ & $71.50(2)$ & $\mathrm{O}\left(3 \_2\right)$ & $\mathrm{Ca}(1)$ & $\mathrm{O}\left(4 \_2\right)$ & $63.18(2)$ \\
\hline
\end{tabular}

Contrary to expectations, neither of the crystallographically independent O6 oxygen atoms of the calcium gluconate structure participate in calcium binding. Instead, both contribute to hydrogen bonding interactions linking adjacent polynuclear chains and the solvates together. O6_1 acts as the hydrogen donor in hydrogen bonding to the water molecule in the same asymmetric unit and as an acceptor in a bonding interaction with O3_1 of an adjacent Gluc1 unit. O6_2 acts as a hydrogen bond donor to the carboxylate $\mathrm{O}^{\prime}{ }^{\prime} 2$ of a symmetry related Gluc2 and as an acceptor in a hydrogen bond with a nearby water molecule.

Of the oxygen atoms of Gluc1, all but the carboxylate oxygen (O1_1) participate in interchain hydrogen bonding interactions that, collectively, constitute a threedimensional network (Fig. 33). O1'_1 acts as an acceptor in hydrogen bonding interaction with O4_2 in an adjoining asymmetric unit of the same chain and with the O5_1 in an adjacent chain. O2_1 is a donor in a hydrogen bonding interaction with $04 \_2$ of the same ligand and O6_2 in an adjacent chain. O3_1 acts as an acceptor in a hydrogen bond with 
O2_2 of an adjacent Gluc2 in an adjoining asymmetric unit of the same chain. O3_1 also acts as a donor in an interaction with O6_1 of a Gluc1 in an adjacent chain. O4_1 participates in three hydrogen bonding interactions. It acts as a donor to $\mathrm{Ol}^{\prime}, 1$ in an adjoining asymmetric unit of the same chain. It is also an acceptor for O2_1 of the same ligand and O5_2 on an adjacent chain. In contrast, O5_1 participates in only one hydrogen bond, acting as a donor to $\mathrm{O}^{\prime}{ }_{-} 1$ on an adjacent chain.

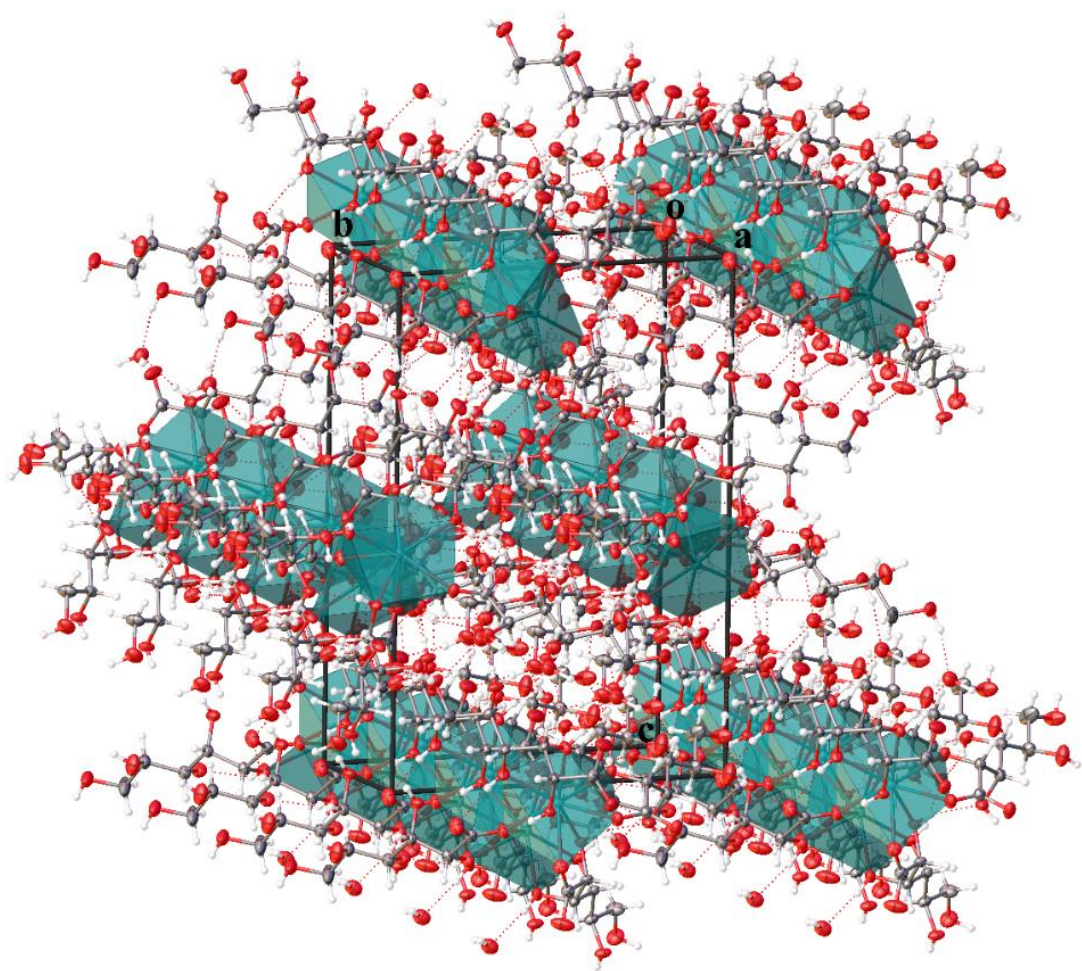

Figure 33. Hydrogen bonds link polynuclear chains of $\mathrm{CaGluc}_{2}$ running parallel to the $a$ axis in the $100 \mathrm{~K}$ single crystal structure of $\mathrm{CaGluc}_{2} \cdot \mathrm{H}_{2} \mathrm{O}$.

Similarly to Gluc1, only the 01_2 carboxylate oxygen of the six oxygen atoms of Gluc2 does not participate in hydrogen bonding interactions. The other carboxylate of this ligand, $\mathrm{O}^{\prime} \_2$, is an acceptor for O6_2 on an adjacent chain. In addition to bridging between the calcium ion of the asymmetric unit and that of an adjacent asymmetric unit, O2_2 serves as a donor to O3_1 in an adjoining asymmetric unit of the same chain. In addition to coordinating to the calcium ion, $\mathrm{O} 3 \_2$ acts as a donor in an interaction with a water molecule. O4_2 is also coordinated to a calcium, and additionally acts as a donor to $\mathrm{O}^{\prime}, 1$ in an adjoining asymmetric unit of the same chain. O5_2 serves as a donor to O4_1 of a Gluc1 on an adjacent chain and as an acceptor for a water molecule.

The crystallographically unique water molecule acts as an acceptor in two hydrogen bonds, with one involving O3_2 and the other being O6_1 of a symmetry-related Gluc1 
on an adjacent polynuclear chain. It also acts as a donor for two hydrogen bonds, with one involving O6_2 in an adjacent chain and O5_2 of another Gluc2 in the same adjacent chain. The water molecule, thus interacts with three polynuclear chains.

Crystallographic details obtained for both $\mathrm{CaIsa}_{2}$ and $\mathrm{CaGluc}_{2} \cdot \mathrm{H}_{2} \mathrm{O}$ are provided in Table 9.

Table 9. Crystallographic details for $\mathrm{CaGluc}_{2} \cdot \mathrm{H}_{2} \mathrm{O}$ and $\mathrm{CaIsa}_{2}$

\begin{tabular}{lll}
\hline Formula & $\mathrm{Ca}\left(\mathrm{C}_{6} \mathrm{H}_{11} \mathrm{O}_{7}\right)_{2} \cdot \mathrm{H}_{2} \mathrm{O}$ & $\mathrm{Ca}\left(\mathrm{C}_{6} \mathrm{H}_{11} \mathrm{O}_{6}\right)_{2}$ \\
\hline Molecular weight $(\mathrm{g} / \mathrm{mol})$ & 448.39 & 398.37 \\
Crystal system & orthorhombic & orthorhombic \\
Space group & $P 2{ }_{1} 2_{1} 2_{1}(\# 19)$ & $P 2_{1} 2_{1} 2(\# 18)$ \\
Lattice constants & $a=6.71198(9) \AA$ & $a=6.7573(4) \AA$ \\
& $b=13.3641(2) \AA$ & $b=19.587(1) \AA$ \\
& $c=19.5439(3) \AA$ & $c=5.734(1) \AA$ \\
Cell volume & $1,753.08(4) \AA^{3}$ & $759.0(1) \AA^{3}$ \\
Density & $1.699 \mathrm{~g} \cdot \mathrm{cm}^{-3}$ & $1.743 \mathrm{~g} \cdot \mathrm{cm}^{-3}$ \\
Molecules per unit & 4 & 2 \\
Crystal size (mm) & $0.110 \times 0.025 \times 0.024$ & $0.100 \times 0.005 \times 0.005$ \\
Crystal colour & colourless & colourless \\
Crystal habit & block & needle \\
\hline
\end{tabular}

As a comparison, both $\mathrm{CaIsa}_{2}$ and $\mathrm{CaGluc}_{2} \cdot \mathrm{H}_{2} \mathrm{O}$ have non-centrosymmetric orthorhombic structures comprised of coordination polymers parallel to the $a$ axis. Distinguishing it from the structure of CaIsa, adjacent metal centres in the $\mathrm{CaGluc}_{2} \cdot \mathrm{H}_{2} \mathrm{O}$ structure are linked by three $\mu$-oxo bridges. One of the Gluc $^{-}$ligands binds to three metal centres. In contrast, adjacent metal centres in the $\mathrm{CaIsa}_{2}$ structure are spanned by two Isa ${ }^{-}$ ligands, each of which separates the metals by binding one with a pair of hydroxy groups at one end of the ligand and the second with a carboxylate and a hydroxy group at the other end of the ligand. CaIsa 2 is then eightfold coordinated, whereas the calcium ion in the $\mathrm{CaGluc}_{2} \cdot \mathrm{H}_{2} \mathrm{O}$ crystal is coordinated to nine oxygen atoms. The $\mathrm{CaGluc}_{2} \cdot \mathrm{H}_{2} \mathrm{O}$ coordination polyhedron is that of a distorted triaugmented triangular prism and adjoining polyhedra of a given polynuclear chain share a triangular face. The coordination polyhedron in $\mathrm{CaIsa}_{2}$ is a distorted Archimedean antiprism, each of which is isolated from its two neighbours by the bridging ligands. The two structures then have very different hydrogen bond networks and packing arrangements. 


\subsection{Calcium complexing properties of lactate}

\subsubsection{Complexation of $\mathrm{Ca}^{2+}$ by lactate in neutral medium}

In order to examine the complex formation between $\mathrm{Ca}^{2+}$ and $\mathrm{Lac}^{-}$in (close to) neutral medium, potentiometric titrations were carried out using a calcium ion selective electrode, at $\mathrm{T}=(25.0 \pm 0.1)^{\circ} \mathrm{C}$ and $\mathrm{I}=4.0 \mathrm{M}(\mathrm{NaCl})$. The titration curves shown in Fig. 34 show that on increasing $\left[\mathrm{Lac}^{-}\right]_{\mathrm{T}, 0}$, the concentration of the free calcium ions, $\left[\mathrm{Ca}^{2+}\right]$, decreases. The three data sets were fitted simultaneously by minimizing FP. The initial $F P=0.69 \log \left(\left[\mathrm{Ca}^{2+}\right] / \mathrm{M}\right)$ unit decreased to 0.07 with the assumption of the $\mathrm{CaLac}^{+}$ complex with $\log \beta_{1,1}=1.23(4)$ (dashed lines in Fig. 34). However, the significant deviations between the observed and calculated data indicate that other complex(es) is/are also present in the system. These differencies can be markedly decreased (to $F P=0.011$ ) if the $\mathrm{CaLac}_{2}{ }^{0}$ species is also taken into account beside $\mathrm{CaLac}^{+}$(solid lines in Fig. 34) This model gives $\log \beta_{1,1}=0.99(2)$ and $\log \beta_{1,2}=1.42(3)$ for $\mathrm{CaLac}^{+}$and $\mathrm{CaLac}_{2}{ }^{0}$, respectively.

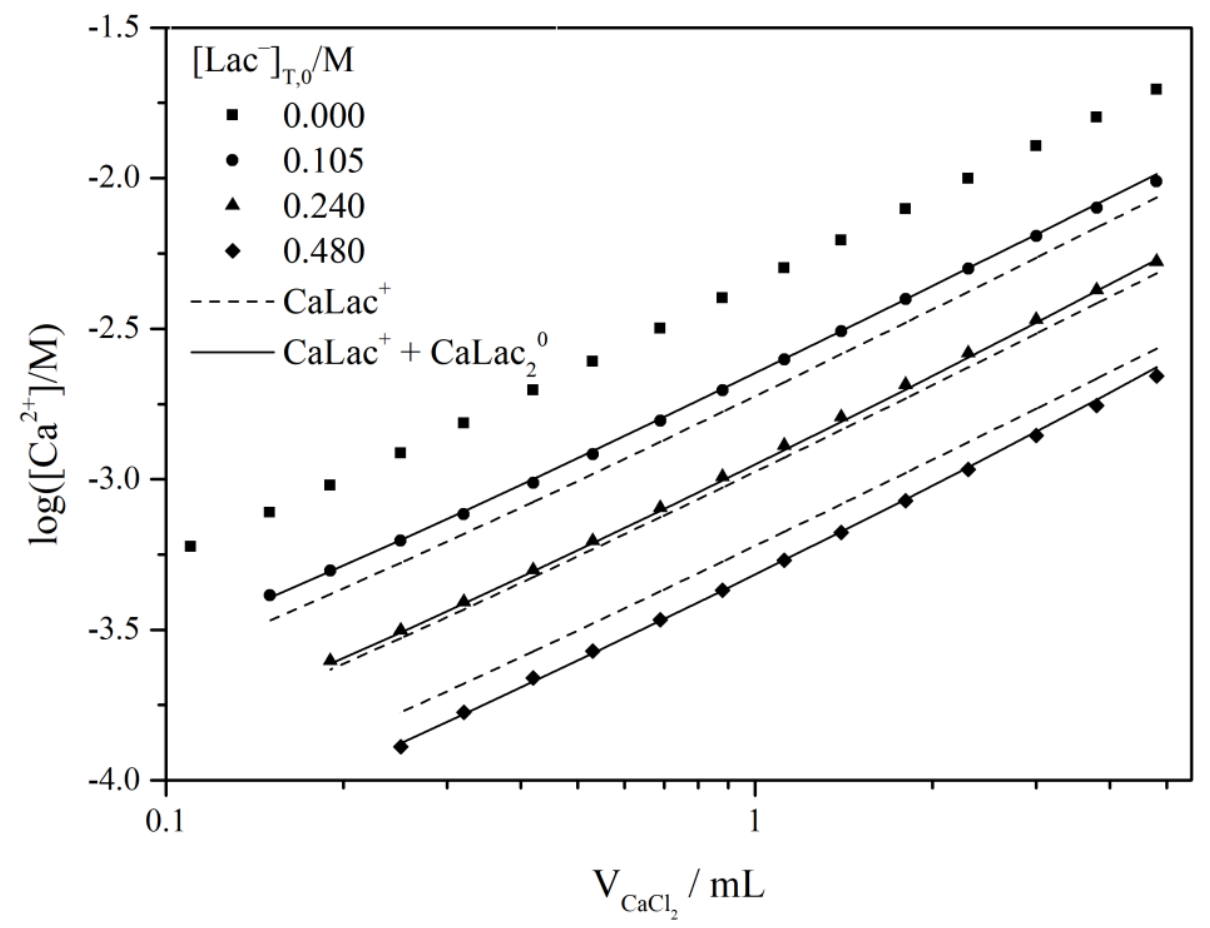

Figure 34. Ca-ISE potentiometric titration curves of solutions containing $\mathrm{Lac}^{-}$and $\mathrm{Ca}^{2+}$ in neutral medium as a function of the added titrant volume (log scale). $\mathrm{V}_{0}=45 \mathrm{~mL},\left[\mathrm{Ca}^{2+}\right]_{\mathrm{T}, 0}=$ $10^{-4} \mathrm{M}$, titrant: $\left[\mathrm{CaCl}_{2}\right]_{\mathrm{T}}=0.2 \mathrm{M}$, initial $\left[\mathrm{Lac}^{-}\right]_{\mathrm{T}}$ values are shown in the figure, $\mathrm{I}=4.0 \mathrm{M}$ $(\mathrm{NaCl}), \mathrm{T}=(25.0 \pm 0.1){ }^{\circ} \mathrm{C}$. Symbols and solid lines represent measured and fitted data, respectively. 
The obtained formation constants are in agreement with the previously reported ones $\left(\log \beta_{1,1}=0.90\right.$ and $\log \beta_{1,2}=1.24$ at $\mathrm{I}=1.0 \mathrm{M}^{[53]}$ and $\log \beta_{1,1}=0.92$ and $\log \beta_{1,2}=1.62$ at $\mathrm{I}=0.5 \mathrm{M}^{[54]}$ ), the difference is most likely due to the different ionic strengths applied.

The distribution diagram in Fig. 35 shows that these formation constants correspond to significant formation of both complexes.

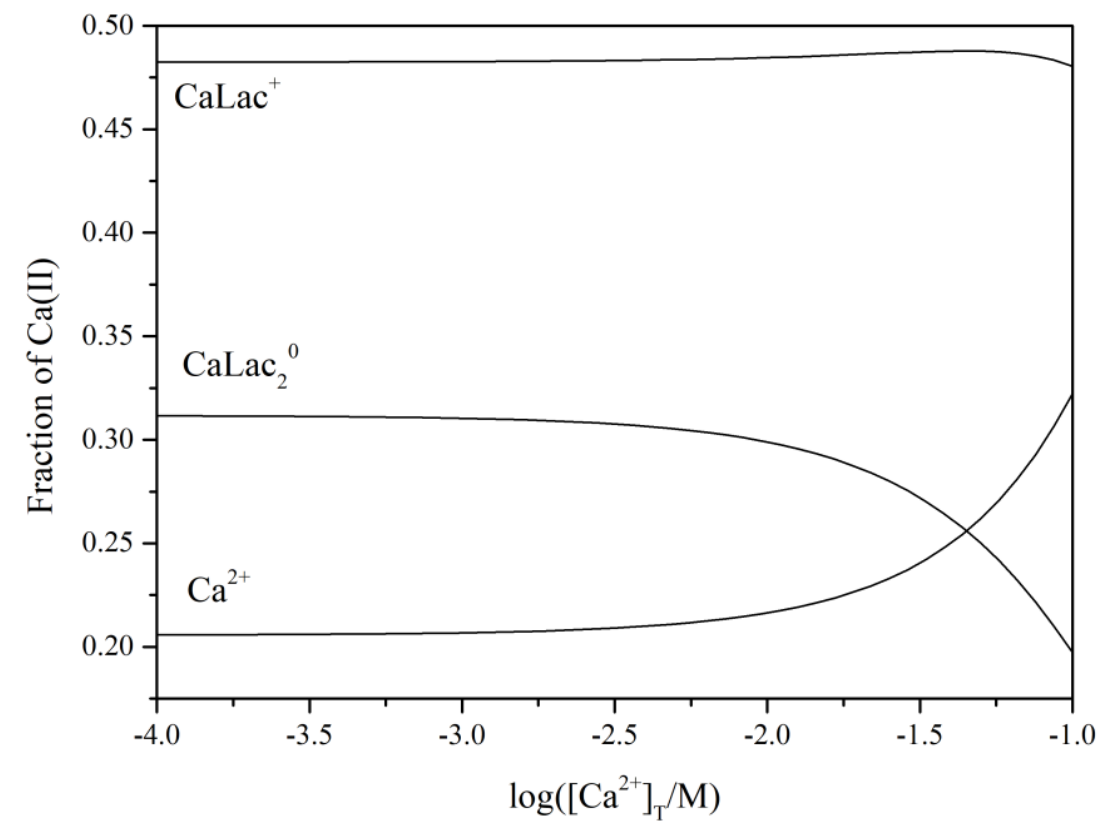

Figure 35. Distribution of $\mathrm{Ca}(\mathrm{II})$ among the various aqueous species in a solution containing $\left[\mathrm{Lac}^{-}\right]_{\mathrm{T}}=0.24 \mathrm{M}$ as a function of $\log \left(\left[\mathrm{Ca}^{2+}\right]_{\mathrm{T}} / \mathrm{M}\right)$.

In order to provide additional proof for the formation of these complexes, ${ }^{13} \mathrm{C}$ NMR measurements were performed. Fig. 36 shows the ${ }^{13} \mathrm{C}$ NMR shifts of the different carbon nuclei of $\mathrm{Lac}^{-}$in solutions containing $\left[\mathrm{Lac}^{-}\right]_{\mathrm{T}}=0.321 \mathrm{M}$ as a function of $\left[\mathrm{Ca}^{2+}\right]_{\mathrm{T}}$. It is seen that upon increasing the concentration of $\mathrm{Ca}^{2+}$, the ${ }^{13} \mathrm{C}$ NMR signals shift downfield due to complex formation. The measured chemical shifts were fitted as a function of $\left[\mathrm{Ca}^{2+}\right]_{\mathrm{T}}$. Since the limiting chemical shifts of the different carbon nuclei of $\mathrm{CaLac}^{+}$and $\mathrm{CaLac}_{2}{ }^{0}$ are rather similar, it was not possible to determine both the formation constants and the limiting chemical shift values from these measurements. However, by holding the $\log \beta$ values (determined by Ca-ISE potentiometry) constant during the fitting, it was possible to calculate the limiting chemical shifts of the complexes. If only the formation of the $\mathrm{CaLac}^{+}$complex is taken into consideration (with $\log \beta_{1,1}=1.23$ ), there are systematic and notable deviations between the measured and the calculated data (Fig. 36, dashed lines), with $F P=0.04 \mathrm{ppm}$. However, if the formation of the $\mathrm{CaLac}_{2}{ }^{0}$ complex is 
also taken into account (using $\log \beta_{1,1}=0.99$ and $\log \beta_{1,2}=1.42$ ), these differences are decreased markedly, FP being 0.009 ppm (Fig. 36, solid lines). These measurements confirm the presence of the $\mathrm{CaLac}_{2}{ }^{0}$ species. The calculated limiting chemical shifts of $\mathrm{C} 1-\mathrm{C} 3$ of $\mathrm{Lac}^{-}, \mathrm{CaLac}^{+}$and $\mathrm{CaLac}_{2}{ }^{0}$ are listed in Table 10. (where $\mathrm{C} 1, \mathrm{C} 2$ and $\mathrm{C} 3$ belong to the carbon nuclei in the $\mathrm{COO}^{-}, \mathrm{CH}_{2} \mathrm{OH}$ and $\mathrm{CH}_{3}$ groups of $\mathrm{Lac}^{-}$, respectively; see Fig. 2 on page 7). It is seen that the values obtained for the three species do not differ from each other significantly.

For ESI-MS measurements, a calcium lactate solution was prepared by dissolving $\mathrm{CaO}$ in a HLac solution, in order to exclude the presence of $\mathrm{Na}^{+}$ions; the thus obtained solution contained $\left[\mathrm{Lac}^{-}\right]_{\mathrm{T}}=0.10 \mathrm{M}$ and $\left[\mathrm{Ca}^{2+}\right]_{\mathrm{T}}=0.050 \mathrm{M}$. On the ESI-MS spectrum of this solution (Fig. 37), the peaks corresponding to both the $\mathrm{CaLac}^{+}$(expected to appear at $128.9865 \mathrm{~m} / \mathrm{z}$ value) and $\mathrm{CaLac}_{2}{ }^{0}$ complexes appeared confirming the presence of both species. The peak referring to $\mathrm{CaLac}_{2}{ }^{0}$ appeared in the spectrum gaining one positive charge via binding a proton, i.e. as $\mathrm{CaLac}_{2} \mathrm{H}^{+}$, therefore, it is expected to appear at $219.0182 \mathrm{~m} / \mathrm{z}$ value. Moreover, further satellites of low intensity can be detected, due to other, low abundance isotopes. The peak positions obtained are in excellent agreement with the calculated ones.

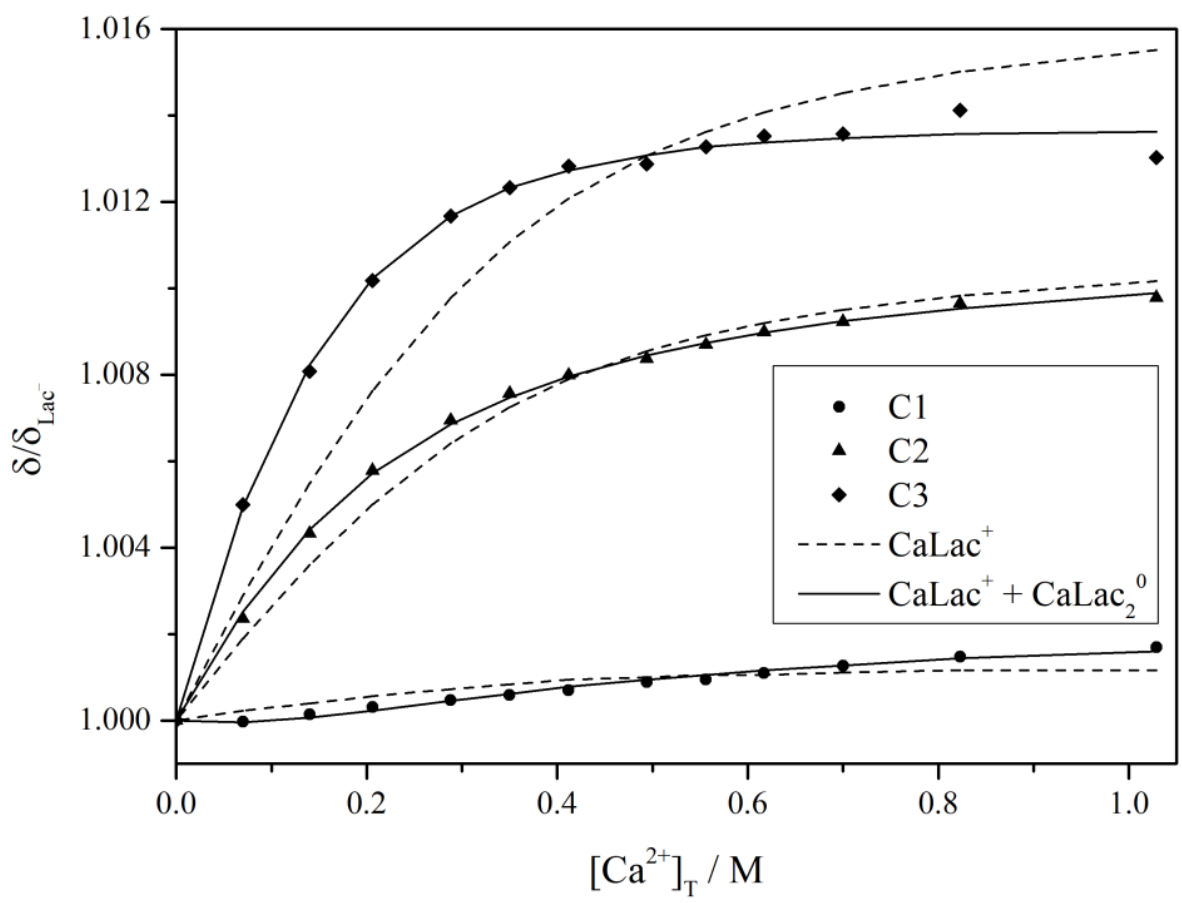

Figure 36. ${ }^{13} \mathrm{C}$ NMR chemical shifts of each carbon atom of $\mathrm{Lac}^{-}$as a function of $\left[\mathrm{Ca}^{2+}\right]_{\mathrm{T}}$. Experimental conditions: $\left[\mathrm{Lac}^{-}\right]_{\mathrm{T}}=0.321 \mathrm{M}, \mathrm{T}=(25 \pm 1)^{\circ} \mathrm{C}, \mathrm{I}=4.0 \mathrm{M}(\mathrm{NaCl})$. Symbols and solid lines represent measured and calculated data, respectively. The chemical shifts $(\delta)$ were normalized to those of the non-complexed $\mathrm{Lac}^{-}$ion $\left(\delta_{\mathrm{Lac}}\right)$ for better visualization. 
Table 10. Chemical shifts of the different carbon nuclei of $\mathrm{Lac}^{-}, \mathrm{CaLac}^{+}$and $\mathrm{CaLac}_{2}{ }^{0}$, calculated from ${ }^{13} \mathrm{C}$ NMR measurements.

\begin{tabular}{lccc}
\hline Species & $\delta_{\mathrm{C} 1}$ & $\delta_{\mathrm{C} 2}$ & $\delta_{\mathrm{C} 3}$ \\
\hline $\mathrm{Lac}^{-}$ & 182.11 & 67.99 & 20.05 \\
$\mathrm{CaLac}^{+}$ & 182.56 & 68.75 & 20.31 \\
$\mathrm{CaLac}_{2}{ }^{0}$ & 181.70 & 68.63 & 20.56 \\
\hline
\end{tabular}

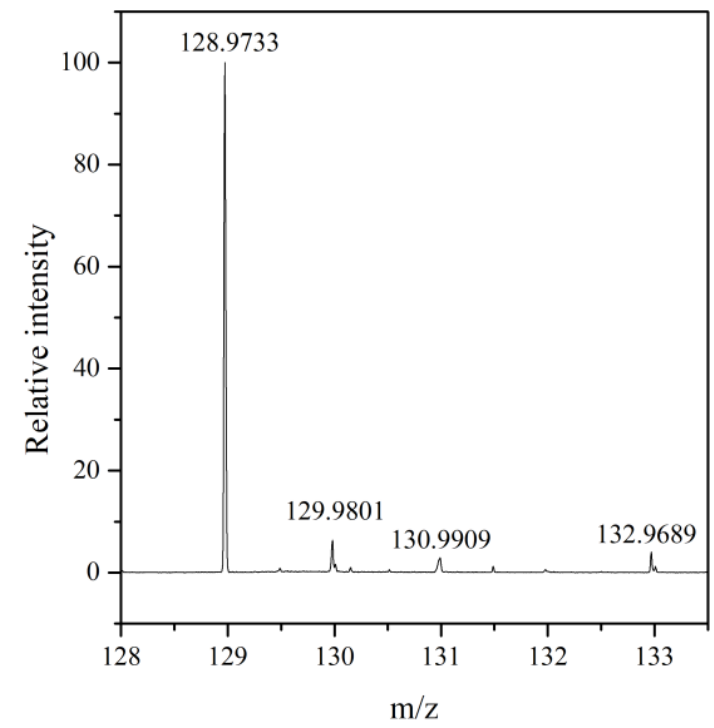

(a)

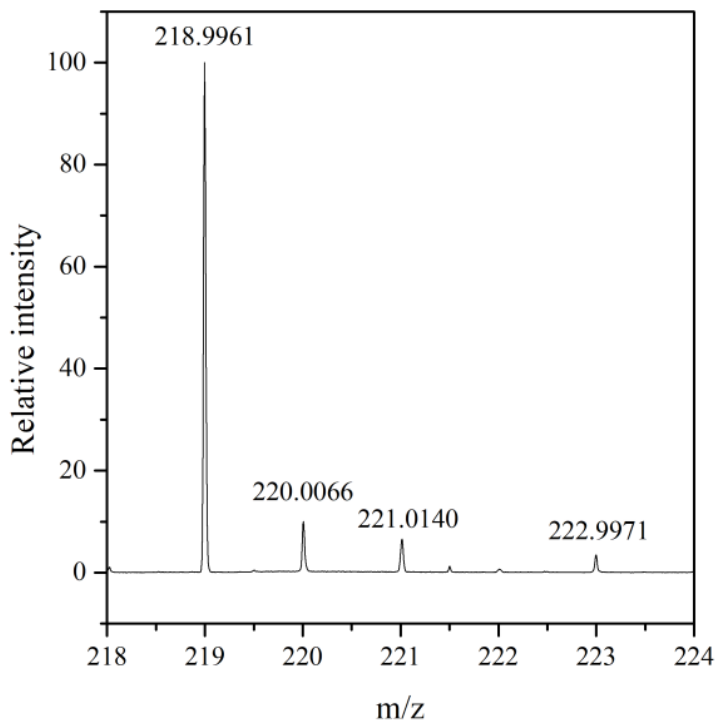

(b)

Figure 37. ESI-MS spectra of a solution containing $\left[\mathrm{Lac}^{-}\right]_{\mathrm{T}}=0.10 \mathrm{M}$ and $\left[\mathrm{Ca}^{2+}\right]_{\mathrm{T}}=0.050 \mathrm{M}$, (a): $\mathrm{CaLac}^{+}$, (b): $\mathrm{CaLac}_{2} \mathrm{H}^{+}$.

In conclusion, the formation of the $\mathrm{CaLac}_{2}{ }^{0}$ species is confirmed by two independent methods agreeing well with previous literature results. ${ }^{[53,54]}$ The formation of 1:2 species was also found for other hydroxy carboxylates, such as D-gluconate and D-heptagluconate. ${ }^{[162]}$

\subsubsection{Deprotonation of lactate in neutral medium}

The alkaline deprotonation of the alcoholic $\mathrm{OH}$ group of $\mathrm{Lac}^{-}$was studied by ${ }^{13} \mathrm{C}$ NMR spectroscopy. Upon increasing $\left[\mathrm{OH}^{-}\right]_{\mathrm{T}}$ in a solution containing $\left[\mathrm{Lac}^{-}\right]_{\mathrm{T}}=0.0960 \mathrm{M}$ or $0.1525 \mathrm{M}$ (Fig. 38. a and b, respectively), the $\mathrm{C} 1$ and $\mathrm{C} 3$ signals of $\mathrm{Lac}^{-}$shift downfield, while that of $\mathrm{C} 2$ shifts upfield as a result of the $\mathrm{OH}$ deprotonation process. 


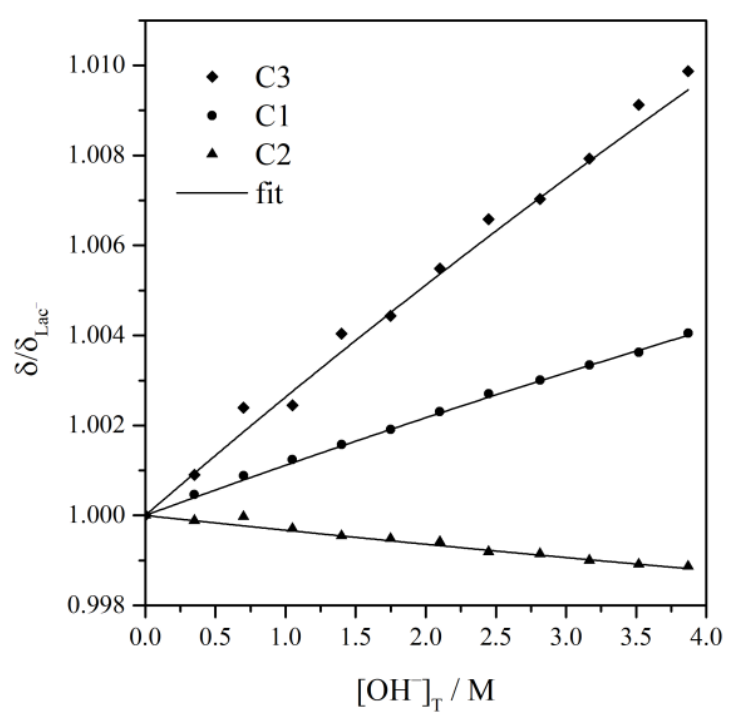

(a)

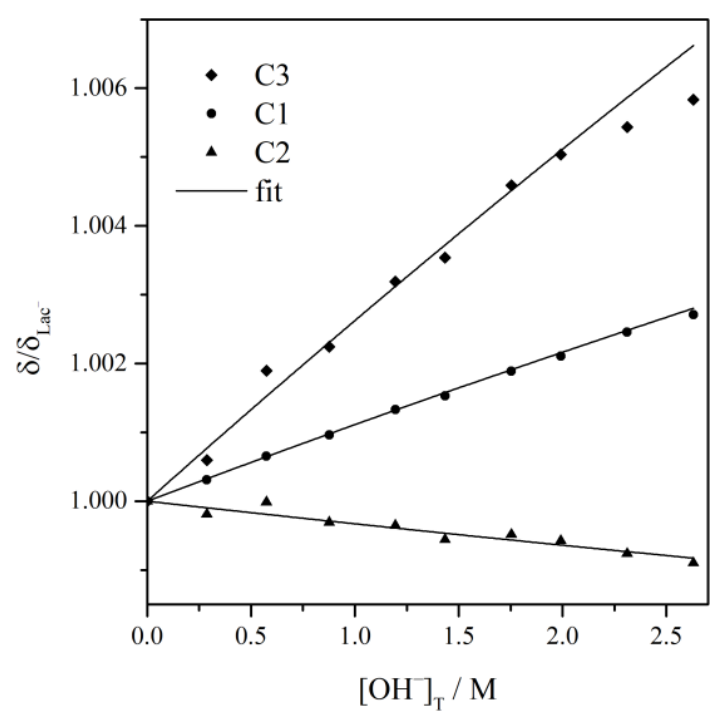

(b)

Figure 38. ${ }^{13} \mathrm{C}$ NMR chemical shifts of each carbon atom of $\mathrm{Lac}^{-}$in terms of $\left[\mathrm{OH}^{-}\right]_{\mathrm{T}}$. Experimental conditions: $\left[\mathrm{Lac}^{-}\right]_{\mathrm{T}}=0.0960 \mathrm{M}$ (a) and $0.1525 \mathrm{M}(\mathrm{b}), \mathrm{T}=(25 \pm 1){ }^{\circ} \mathrm{C}, \mathrm{I}=4.0 \mathrm{M}$ $(\mathrm{NaCl})$. Symbols and solid lines represent measured and fitted data, respectively. The measured $\delta$ values were normalized to those of the non-complexed $\mathrm{Lac}^{-}$ion for better visualization.

Since the proton exchange between $\mathrm{Lac}^{-}$and $\mathrm{LacH}_{-1}{ }^{2-}$ is fast on the ${ }^{13} \mathrm{C} \mathrm{NMR}$ timescale, the following relation could be applied (similarly to the Isa ${ }^{-}$-containing solutions; see Eq. 11 on page 29):

$$
\delta_{\mathrm{obs}}=\frac{\delta_{\mathrm{Lac}^{-}}\left[\mathrm{Lac}^{-}\right]+\delta_{\mathrm{LacH}_{-1}{ }^{-2}}\left[\mathrm{LacH}_{-1}{ }^{2-}\right]}{\left[\mathrm{Lac}^{-}\right]_{\mathrm{T}}}
$$

where $\delta_{\text {obs }}$ is the observed chemical shift, $\delta_{\mathrm{Lac}^{-}}$and $\delta_{\mathrm{LacH}_{-1}{ }^{2-}}$ are the limiting chemical shifts of $\mathrm{Lac}^{-}$and $\mathrm{LacH}_{-1}{ }^{2-}$, respectively. During calculations, the measured chemical shift values were fitted against $\left[\mathrm{OH}^{-}\right]_{\mathrm{T}}$, additionally, for the ionic product of water $\mathrm{p} K_{\mathrm{w}}=14.26$ value was used. ${ }^{[167]}$ The thus obtained deprotonation constant is $\mathrm{p} K_{\mathrm{a}}=15.8(2)$ with $F P$ being 0.008 . This value is similar to that obtained for methanol and ethanol (15.5 and 15.9, respectively $\left.{ }^{[167]}\right)$ The relatively large uncertainty is due to the low extent of deprotonation, reaching only $\sim 10 \%$ even at $\left[\mathrm{OH}^{-}\right]_{\mathrm{T}}=4.0 \mathrm{M}$ (see distribution diagram in Fig. 39).

Based on this result, $\mathrm{Lac}^{-}$is a significantly weaker acid than $\mathrm{Isa}^{-}$, for which a $\mathrm{p} K_{\mathrm{a}}=14.5(1)$ value was determined at $\mathrm{I}=1.0 \mathrm{M}$ (see section 5.1.2.). 


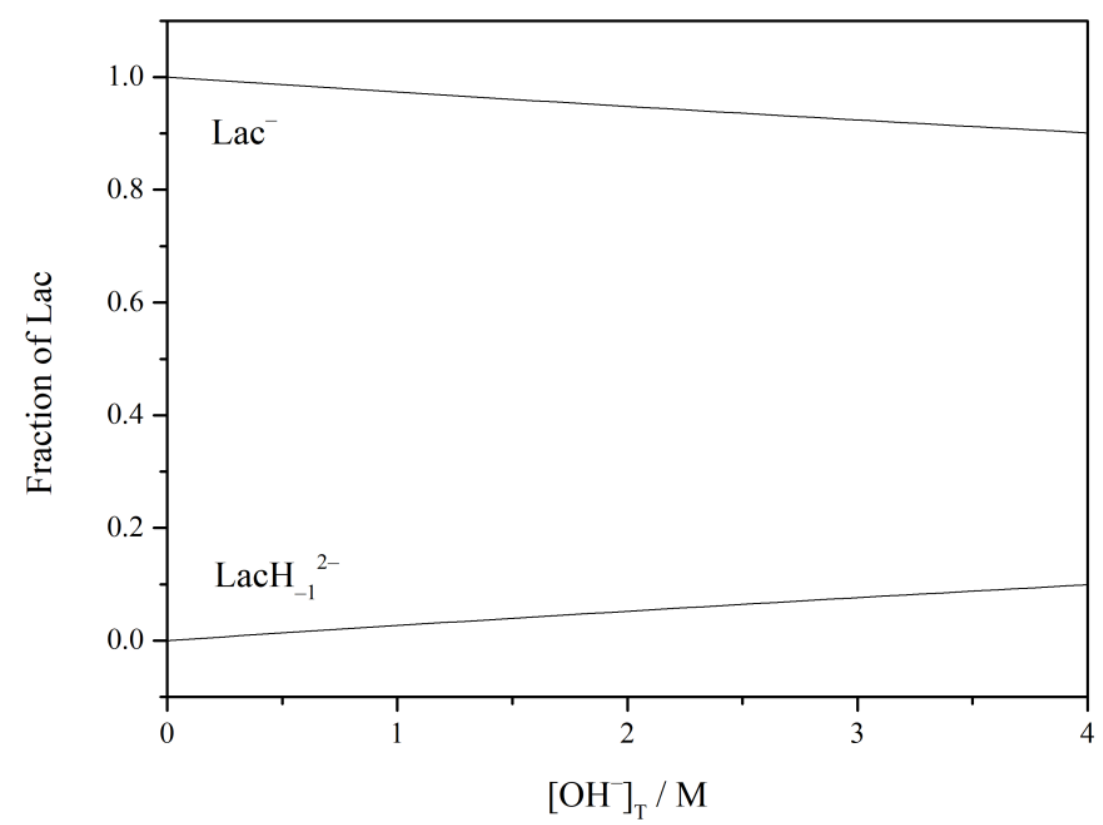

Figure 39. Distribution of Lac among the aqueous species in a solution containing $\left[\mathrm{Lac}^{-}\right]_{\mathrm{T}}=$ $0.10 \mathrm{M}$ as a function of $\left[\mathrm{OH}^{-}\right]_{\mathrm{T}}$.

\subsubsection{Complexation of $\mathrm{Ca}^{2+}$ by lactate in alkaline medium}

Since the alkaline deprotonation constant of the $\mathrm{OH}$ group of $\mathrm{Lac}^{-}, \mathrm{p} K_{\mathrm{a}}$, is rather large, $\mathrm{H}_{2} / \mathrm{Pt}$ potentiometry is unsuitable to characterize the complex formation between $\mathrm{Ca}^{2+}$ and $\mathrm{Lac}^{-}$in alkaline medium because of the limited solubility of $\mathrm{Ca}(\mathrm{OH})_{2}$. Therefore, solubility measurements were performed at $\mathrm{T}=(25 \pm 2){ }^{\circ} \mathrm{C}$ and $\mathrm{I}=4.0 \mathrm{M}(\mathrm{NaCl})$.

The maximum dissolved $\mathrm{Ca}(\mathrm{II})$ in solutions containing $\left[\mathrm{Lac}^{-}\right]_{\mathrm{T}}=0.50 \mathrm{M}$ and $\mathrm{c}_{\mathrm{NaOH}}=0.14-2.63 \mathrm{M}$ was measured by ICP-OES. Fig. 40 shows that $\left[\mathrm{Ca}^{2+}\right]_{\mathrm{T}}$ systematically decreases upon increasing $\left[\mathrm{OH}^{-}\right]_{\mathrm{T}}$. The logarithm of the measured $\left[\mathrm{Ca}^{2+}\right]_{\mathrm{T}}$ values were fitted with respect to $\left[\mathrm{OH}^{-}\right]$with the aid of the OriginPro software package. ${ }^{[169]}$ During data evaluation, the ionic product of water was taken as $\mathrm{p} K_{\mathrm{w}}=14.26^{[167]}$. The mathematical relationships applied during data fitting are detailed as follows.

Since $\left[\mathrm{Ca}^{2+}\right]_{\mathrm{T}}$ was measured as a function of the concentration of the added base, $\mathrm{c}_{\mathrm{NaOH}},\left[\mathrm{Ca}^{2+}\right]_{\mathrm{T}}$ should be fitted as a function of $\mathrm{c}_{\mathrm{NaOH}}$. However, $\mathrm{c}_{\mathrm{NaOH}}$ is related to the total concentration of hydroxide, $\left[\mathrm{OH}^{-}\right]_{\mathrm{T}}$, as follows: $\left[\mathrm{OH}^{-}\right]_{\mathrm{T}}=\mathrm{c}_{\mathrm{NaOH}}+2\left[\mathrm{Ca}^{2+}\right]_{\mathrm{T}}$ as each dissolved $\mathrm{Ca}^{2+}$ ion leads to the simultaneous dissolution of two $\mathrm{OH}^{-}$counterions. Consequently, at higher values of $\left[\mathrm{Ca}^{2+}\right]_{\mathrm{T}}$ (i.e., at lower $\mathrm{pH}$ ), the $\left[\mathrm{OH}^{-}\right]_{\mathrm{T}}>c_{\mathrm{NaOH}}$ inequality holds. Furthermore, as the lowest $\left[\mathrm{OH}^{-}\right]_{\mathrm{T}} /\left[\mathrm{Ca}^{2+}\right]_{\mathrm{T}}$ ratio is around 11 , it is safe to assume that the sum of the concentrations of the hydroxide-containing species are 
significantly lower than $\left[\mathrm{OH}^{-}\right]_{\mathrm{T}}$, thus, the approximation of $\left[\mathrm{OH}^{-}\right] \approx\left[\mathrm{OH}^{-}\right]_{\mathrm{T}}$ was applied. Therefore, the function of $\left[\mathrm{Ca}^{2+}\right]_{\mathrm{T}} v s .\left[\mathrm{OH}^{-}\right]$was used.

The species $\mathrm{Lac}^{-}, \mathrm{OH}^{-}, \mathrm{Ca}^{2+}, \mathrm{LacOH}^{2-}, \mathrm{CaLac}^{+}, \mathrm{CaLac}_{2}{ }^{0}, \mathrm{CaOH}^{+}, \mathrm{Ca}(\mathrm{OH})_{2}{ }^{0}$, $\mathrm{CaLacOH}^{0}$ and $\mathrm{CaLacOH}_{2}{ }^{-}$are supposed to exist in heterogeneous equilibrium with $\mathrm{Ca}(\mathrm{OH})_{2}(\mathrm{~s})$. The chemical equilibria with the corresponding formation constants are listed below (the formation constants are expressed with $\mathrm{OH}^{-}$ions):

$$
\begin{array}{ll}
\mathrm{Ca}^{2+}+2 \mathrm{OH}^{-} \rightleftharpoons \underline{\mathrm{Ca}(\mathrm{OH})_{2}} & L=\left[\mathrm{Ca}^{2+}\right]\left[\mathrm{OH}^{-}\right]^{2}=3 \cdot 10^{-5}[166] \\
\mathrm{Ca}^{2+}+\mathrm{Lac}^{-} \rightleftharpoons \mathrm{CaLac}^{+} & K_{1}=\left[\mathrm{CaLac}^{+}\right] /\left(\left[\mathrm{Ca}^{2+}\right]\left[\mathrm{Lac}^{-}\right]\right)=9.77 \\
\mathrm{Ca}^{2+}+2 \mathrm{Lac}^{-} \rightleftharpoons \mathrm{CaLac}_{2}{ }^{0} & \beta_{1}=\left[\mathrm{CaLac}_{2}{ }^{0}\right] /\left(\left[\mathrm{Ca}^{2+}\right]\left[\mathrm{Lac}^{-}\right]^{2}\right)=26.30 \\
\mathrm{Ca}^{2+}+\mathrm{OH}^{-} \rightleftharpoons \mathrm{CaOH}^{+} & K_{2}=\left[\mathrm{CaOH}^{+}\right] /\left(\left[\mathrm{Ca}^{2+}\right]\left[\mathrm{OH}^{-}\right]\right)=2.2^{[166]} \\
\mathrm{Ca}^{2+}+2 \mathrm{OH}^{-} \rightleftharpoons \mathrm{Ca}(\mathrm{OH})_{2}{ }^{0} & \beta_{2}=\left[\mathrm{Ca}(\mathrm{OH})_{2}{ }^{0}\right] /\left(\left[\mathrm{Ca}^{2+}\right]\left[\mathrm{OH}^{-}\right]^{2}\right)=7.5^{[166]} \\
\mathrm{Lac}^{-}+\mathrm{OH}^{-} \rightleftharpoons \mathrm{LaCOH}^{2-} & K_{3}=\left[\mathrm{LacOH}^{2-}\right] /\left(\left[\mathrm{Lac}^{-}\right]\left[\mathrm{OH}^{-}\right]\right)=0.0288 \\
\mathrm{Ca}^{2+}+\mathrm{Lac}^{-}+\mathrm{OH}^{-} \rightleftharpoons \mathrm{CaLacOH}^{0} & \beta_{3}=\left[\mathrm{CaLacOH}{ }^{0}\right] /\left(\left[\mathrm{Ca}^{2+}\right]\left[\mathrm{Lac}^{-}\right]\left[\mathrm{OH}^{-}\right]\right) \\
\mathrm{Ca}^{2+}+\mathrm{Lac}^{-}+2 \mathrm{OH}^{-} \rightleftharpoons \mathrm{CaLac}(\mathrm{OH})_{2}{ }^{-} & \beta_{4}=\left[\mathrm{CaLac}(\mathrm{OH})_{2}{ }^{-}\right] /\left(\left[\mathrm{Ca}^{2+}\right]\left[\mathrm{Lac}^{-}\right]\left[\mathrm{OH}^{-}\right]^{2}\right)
\end{array}
$$

The total concentrations of $\mathrm{Lac}^{-}$and $\mathrm{Ca}^{2+}$ can be expressed as:

$$
\begin{aligned}
{\left[\mathrm{Ca}^{2+}\right]_{\mathrm{T}}=} & {\left[\mathrm{Ca}^{2+}\right]+\left[\mathrm{CaLac}^{+}\right]+\left[\mathrm{CaLac}_{2}{ }^{0}\right]+\left[\mathrm{CaOH}^{+}\right]+\left[\mathrm{Ca}(\mathrm{OH})_{2}{ }_{2}^{0}\right]+\left[\mathrm{CaLacOH}^{0}\right]+} \\
& +\left[\mathrm{CaLac}(\mathrm{OH})_{2}{ }^{-}\right] . \\
{\left[\mathrm{Lac}^{-}\right]_{\mathrm{T}}=} & {\left[\mathrm{Lac}^{-}\right]+\left[\mathrm{CaLac}^{+}\right]+2\left[\mathrm{CaLac}_{2}{ }^{0}\right]+\left[\mathrm{LacOH}^{2-}\right]+\left[\mathrm{CaLacOH}^{0}\right]+\left[\mathrm{CaLac}(\mathrm{OH})_{2}^{-}\right] }
\end{aligned}
$$

Rearranging Eqs. 16-23., the following equilibrium relations can be deduced:

$\left[\mathrm{Ca}^{2+}\right]=L /\left[\mathrm{OH}^{-}\right]^{2}$

$\left[\mathrm{CaLac}^{+}\right]=K_{1}\left[\mathrm{Ca}^{2+}\right]\left[\mathrm{Lac}^{-}\right]=K_{1} L\left[\mathrm{Lac}^{-}\right] /\left[\mathrm{OH}^{-}\right]^{2}$

$\left[\mathrm{CaLac}_{2}{ }^{0}\right]=\beta_{1}\left[\mathrm{Ca}^{2+}\right]\left[\mathrm{Lac}^{-}\right]^{2}=\beta_{1} L\left[\mathrm{Lac}^{-}\right]^{2} /\left[\mathrm{OH}^{-}\right]^{2}$

$\left[\mathrm{CaOH}^{+}\right]=K_{2}\left[\mathrm{Ca}^{2+}\right]\left[\mathrm{OH}^{-}\right]=K_{2} L /\left[\mathrm{OH}^{-}\right]$

$\left[\mathrm{Ca}(\mathrm{OH})_{2}{ }^{0}\right]=\beta_{2}\left[\mathrm{Ca}^{2+}\right]\left[\mathrm{OH}^{-}\right]^{2}=\beta_{2} L$

$\left[\mathrm{LacOH}^{2-}\right]=K_{3}\left[\mathrm{Lac}^{-}\right]\left[\mathrm{OH}^{-}\right]$

$\left[\mathrm{CaLacOH}^{0}\right]=\beta_{3}\left[\mathrm{Ca}^{2+}\right]\left[\mathrm{Lac}^{-}\right]\left[\mathrm{OH}^{-}\right]=\beta_{3} L\left[\mathrm{Lac}^{-}\right] /\left[\mathrm{OH}^{-}\right]$

$\left[\mathrm{CaLac}(\mathrm{OH})_{2}^{-}\right]=\beta_{4}\left[\mathrm{Ca}^{2+}\right]\left[\mathrm{Lac}^{-}\right]\left[\mathrm{OH}^{-}\right]^{2}=\beta_{4} L\left[\mathrm{Lac}^{-}\right]$

Replacing the concentrations of the species in Eq. 24. with the corresponding expressions from Eqs. 26-33.:

$$
\begin{aligned}
{\left[\mathrm{Ca}^{2+}\right]_{\mathrm{T}}=} & L /\left[\mathrm{OH}^{-}\right]^{2}+K_{1} L\left[\mathrm{Lac}^{-}\right] /\left[\mathrm{OH}^{-}\right]^{2}+\beta_{1} L\left[\mathrm{Lac}^{-}\right]^{2} /\left[\mathrm{OH}^{-}\right]^{2}+K_{2} L /\left[\mathrm{OH}^{-}\right]+\beta_{2} L+ \\
& +\beta_{3} L\left[\mathrm{Lac}^{-}\right] /\left[\mathrm{OH}^{-}\right]+\beta_{4} L\left[\mathrm{Lac}^{-}\right]
\end{aligned}
$$

Replacing the concentrations of the species in Eq. 25. with the corresponding expressions from Eqs. 26-33.: 
$\left[\mathrm{Lac}^{-}\right]_{\mathrm{T}}=\left[\mathrm{Lac}^{-}\right]+K_{1} L\left[\mathrm{Lac}^{-}\right] /\left[\mathrm{OH}^{-}\right]^{2}+2 \beta_{1} L\left[\mathrm{Lac}^{-}\right]^{2} /\left[\mathrm{OH}^{-}\right]^{2}+K_{3}\left[\mathrm{Lac}^{-}\right]\left[\mathrm{OH}^{-}\right]+$

$$
\begin{aligned}
& +\beta_{3} L\left[\mathrm{Lac}^{-}\right] /\left[\mathrm{OH}^{-}\right]+\beta_{4} L\left[\mathrm{Lac}^{-}\right]= \\
& =2 \beta_{1} L /\left[\mathrm{OH}^{-}\right]^{2}\left[\mathrm{Lac}^{-}\right]^{2}+\left(1+K_{1} L /\left[\mathrm{OH}^{-}\right]^{2}+K_{3}\left[\mathrm{OH}^{-}\right]+\beta_{3} L /\left[\mathrm{OH}^{-}\right]+\beta_{4} L\right)\left[\mathrm{Lac}^{-}\right]
\end{aligned}
$$

$0=2 \beta_{1} L /\left[\mathrm{OH}^{-}\right]^{2}\left[\mathrm{Lac}^{-}\right]^{2}+\left(1+K_{1} L /\left[\mathrm{OH}^{-}\right]^{2}+K_{3}\left[\mathrm{OH}^{-}\right]+\beta_{3} L /\left[\mathrm{OH}^{-}\right]+\beta_{4} L\right)\left[\mathrm{Lac}^{-}\right]-\left[\mathrm{Lac}^{-}\right]_{\mathrm{T}}$

$\left[\mathrm{Lac}^{-}\right]=\left(-\left(1+K_{1} L /\left[\mathrm{OH}^{-}\right]^{2}+K_{3}\left[\mathrm{OH}^{-}\right]+\beta_{3} L /\left[\mathrm{OH}^{-}\right]+\beta_{4} L\right)+\left(\left(1+K_{1} L /\left[\mathrm{OH}^{-}\right]^{2}+K_{3}\left[\mathrm{OH}^{-}\right]+\right.\right.\right.$ $\left.\left.\left.\beta_{3} L /\left[\mathrm{OH}^{-}\right]+\beta_{4} L\right)^{2}+8 \beta_{1} L\left[\mathrm{Lac}^{-}\right]_{\mathrm{T}} /\left[\mathrm{OH}^{-}\right]^{2}\right)^{\wedge}(1 / 2)\right) /\left(4 \beta_{1} L /\left[\mathrm{OH}^{-}\right]^{2}\right)$

The final $\left[\mathrm{Ca}^{2+}\right]_{\mathrm{T}} v s .\left[\mathrm{OH}^{-}\right]$function is drawn by substituting the expression given in Eq. 38. for $\left[\mathrm{Lac}^{-}\right]$in Eq. 34. The logarithm of the measured $\left[\mathrm{Ca}^{2+}\right]_{\mathrm{T}}$ values were fitted as a function of $\left[\mathrm{OH}^{-}\right]$by estimating $\beta_{3}$ and $\beta_{4}$.

If the formation of only the simplest $\mathrm{CaLacOH}^{0}$ complex is taken into account (with $\left.\log \beta_{1,1,1}=1.7(1)\right)$, there are systematic and significant deviations between the measured and calculated data, $F P=0.078$ (Fig. 40, dotted lines). This indicates that at least one other species is formed. FP could be lowered to 0.012 by including $\mathrm{CaLac}(\mathrm{OH})_{2}{ }^{-}$to the model beside the $\mathrm{CaLacOH}^{0}$ complex (Fig. 41, solid lines), the corresponding formation constants being $\log \beta_{1,1,1}=1.35(9)$ and $\log \beta_{1,1,2}=1.43(6)$. When only the formation of this 1:1:2 complex is considered, $F P$ is 0.053 (Fig. 40, dashed lines) suggesting that both complexes are present. The distribution diagram in Fig. 41 shows that these complexes are formed in significant quantities. Above $\left[\mathrm{OH}^{-}\right]_{\mathrm{T}}=1 \mathrm{M}$, the $\mathrm{CaLac}(\mathrm{OH})_{2}{ }^{-}$species becomes predominant. It is seen in Fig. 42 that under the experimental conditions applied (i.e. $\left[\mathrm{OH}^{-}\right]_{\mathrm{T}}=0.2-2.6 \mathrm{M}$ ) and in the absence of $\mathrm{Lac}^{-}$, calcium is present almost exclusively as $\mathrm{CaOH}^{+}$and $\mathrm{Ca}(\mathrm{OH})_{2}{ }^{0}$. Consequently, both $\mathrm{CaLacOH}^{0}$ and $\mathrm{CaLac}(\mathrm{OH})_{2}{ }^{-}$ most probably contain a $\mathrm{Lac}^{-}$ligand coordinated to a $\mathrm{CaOH}^{+}$or a $\mathrm{Ca}(\mathrm{OH})_{2}{ }^{0}$ unit, i.e. one or two water molecules coordinated to the $\mathrm{Ca}^{2+}$ ion is/are deprotonated. If the ligand in these species was $\mathrm{LacH}_{-1}{ }^{2-}$ (i.e. a deprotonated lactate), the formation constants would be expected to be significantly larger, as the alcoholate moiety is a significantly stronger base, therefore stronger complexant than a hydroxy group. For instance, for Isa ${ }^{-}$, where ligand deprotonation is suggested to occur, $\log \beta_{1,1,1}$ was found to be 2.40 .

Based on the speciation model given in Eqs. 26-33, the solubility of $\mathrm{Ca}(\mathrm{OH})_{2}(\mathrm{~s})$ was simulated in the presence and absence of $\mathrm{Lac}^{-}$, respectively. The calculated solubility curves are shown in Fig. 43 shows the increase in the maximum soluble calcium concentration in the absence and presence of $\mathrm{Lac}^{-}$. It is seen that $\mathrm{Lac}^{-}$significantly increases the total concentration of calcium. 


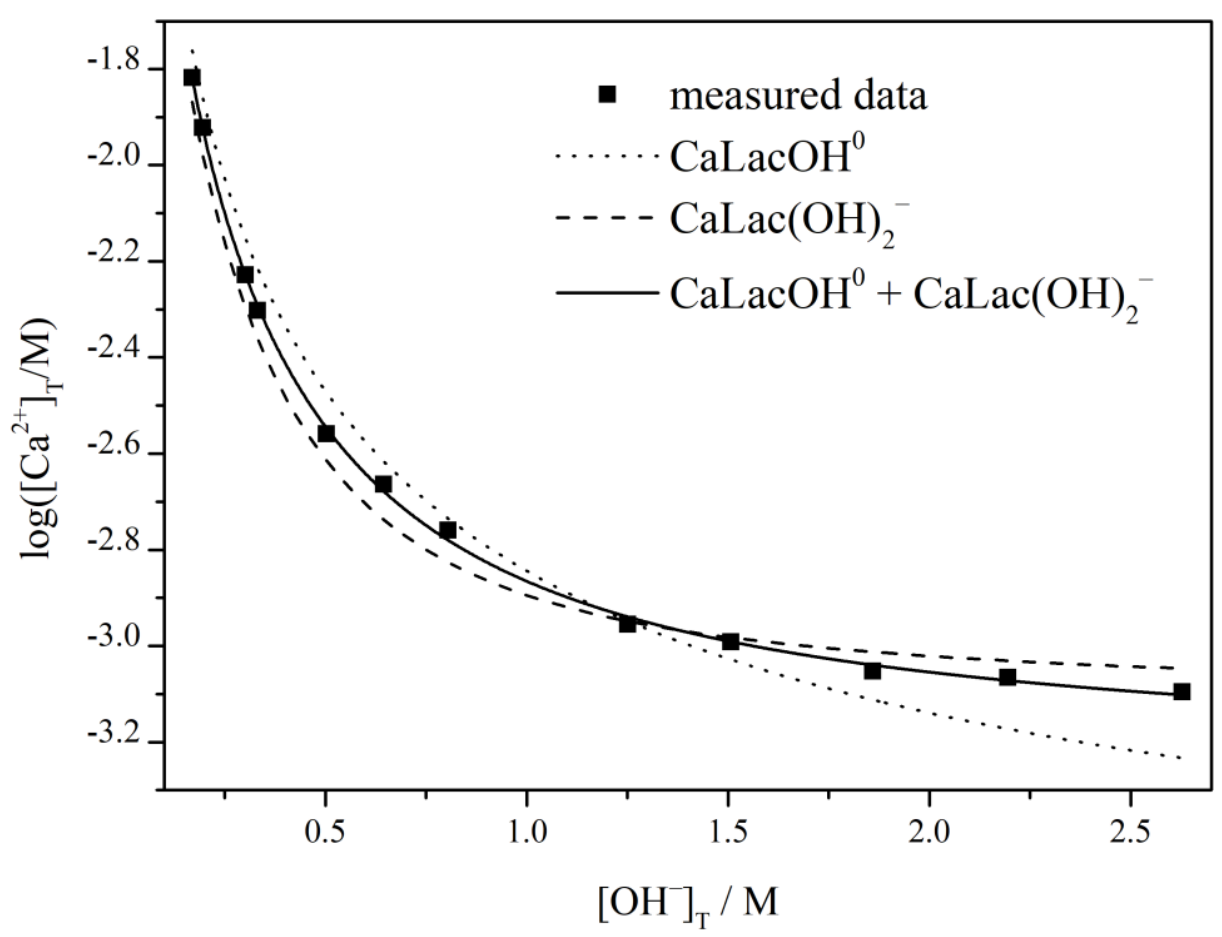

Figure 40. Measured and calculated $\log \left(\left[\mathrm{Ca}^{2+}\right]_{\mathrm{T}} / \mathrm{M}\right)$ values as a function of $\left[\mathrm{OH}^{-}\right]_{\mathrm{T}}$. Experimental conditions: $\left[\mathrm{Lac}^{-}\right]_{\mathrm{T}}=0.50 \mathrm{M},\left[\mathrm{OH}^{-}\right]_{\mathrm{T}}=0.17-2.63 \mathrm{M}, \mathrm{T}=(25 \pm 2)^{\circ} \mathrm{C}, \mathrm{I}=4.0 \mathrm{M}$ $(\mathrm{NaCl})$. Dotted, dashed and solid lines represent the fitted data by assuming the formation of only the $\mathrm{CaLacOH}^{0}$ complex, only the $\mathrm{CaLacOH}^{-}$complex or both species, respectively.

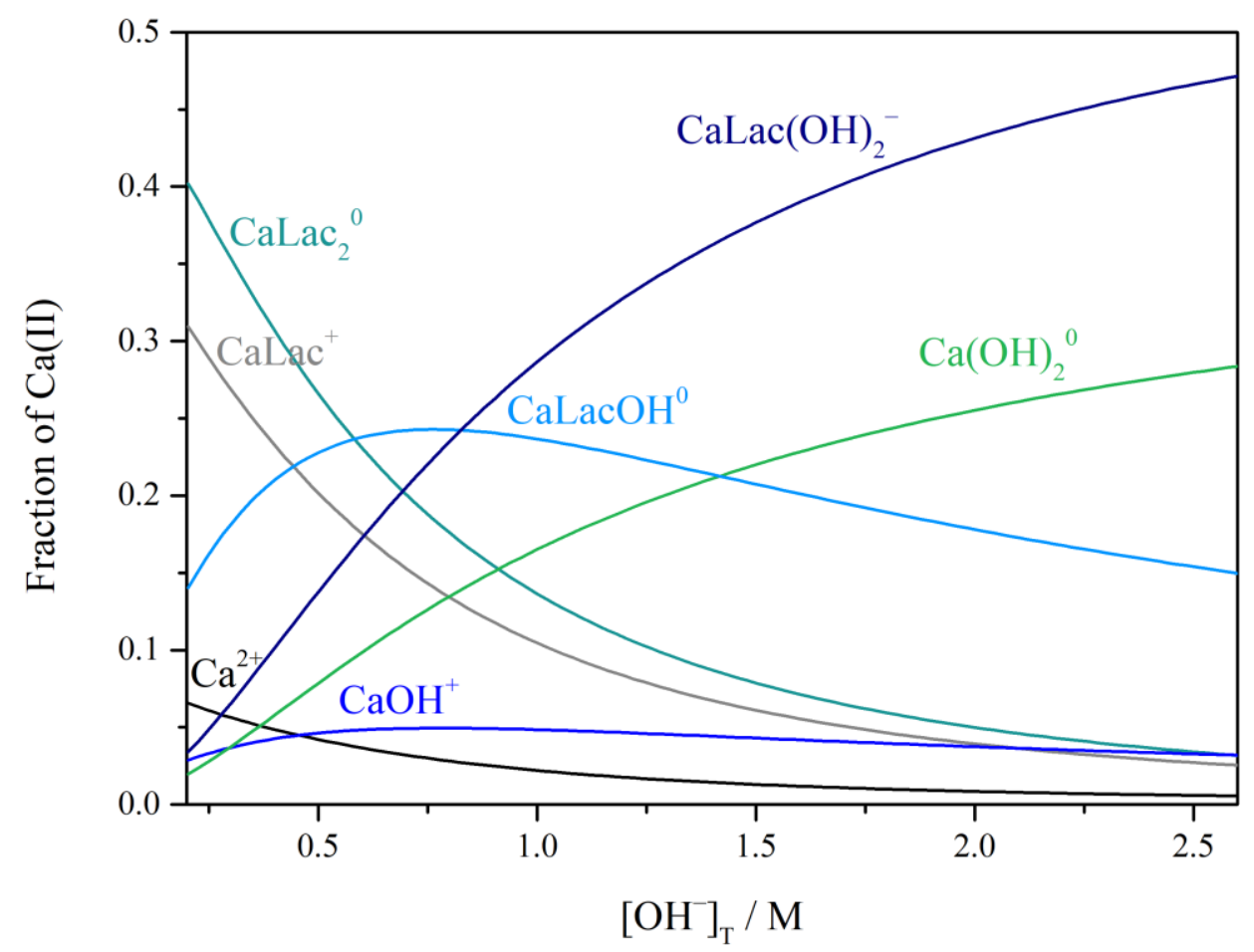

Figure 41. Distribution of $\mathrm{Ca}(\mathrm{II})$ among the various aqueous species in a solution containing $\left[\mathrm{Lac}^{-}\right]_{\mathrm{T}}=0.50 \mathrm{M},\left[\mathrm{Ca}^{2+}\right]_{\mathrm{T}}=0.001 \mathrm{M}$ as a function of $\left[\mathrm{OH}^{-}\right]_{\mathrm{T}}$ assuming heterogeneous equilibrium with respect to $\mathrm{Ca}(\mathrm{OH})_{2}(\mathrm{~s})$. 


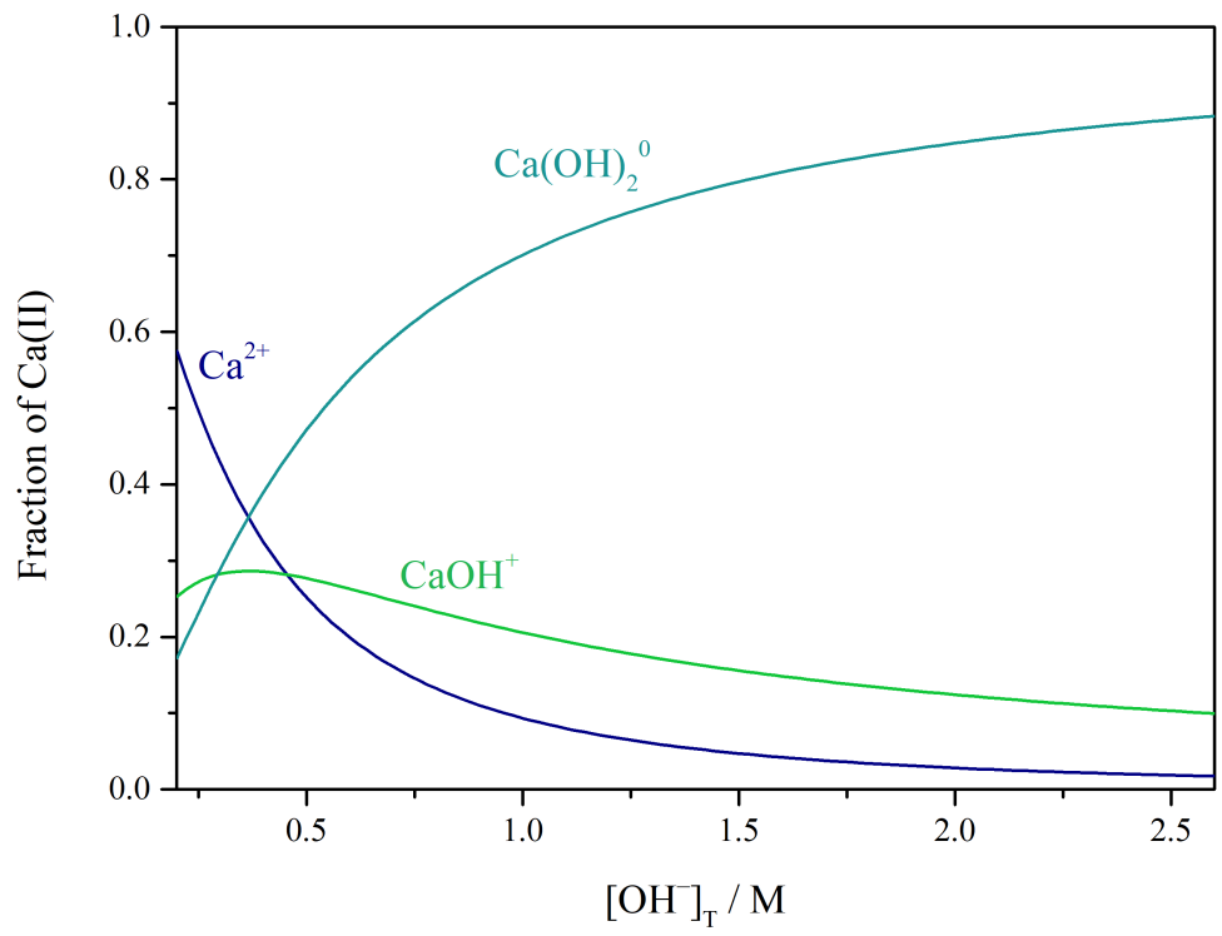

Figure 42. Distribution of $\mathrm{Ca}(\mathrm{II})$ among the various aqueous species in a solution containing $\left[\mathrm{Ca}^{2+}\right]_{\mathrm{T}}=0.001 \mathrm{M}$ as a function of $\left[\mathrm{OH}^{-}\right]_{\mathrm{T}}$ assuming heterogeneous equilibrium with respect to $\mathrm{Ca}(\mathrm{OH})_{2}(\mathrm{~s})$.

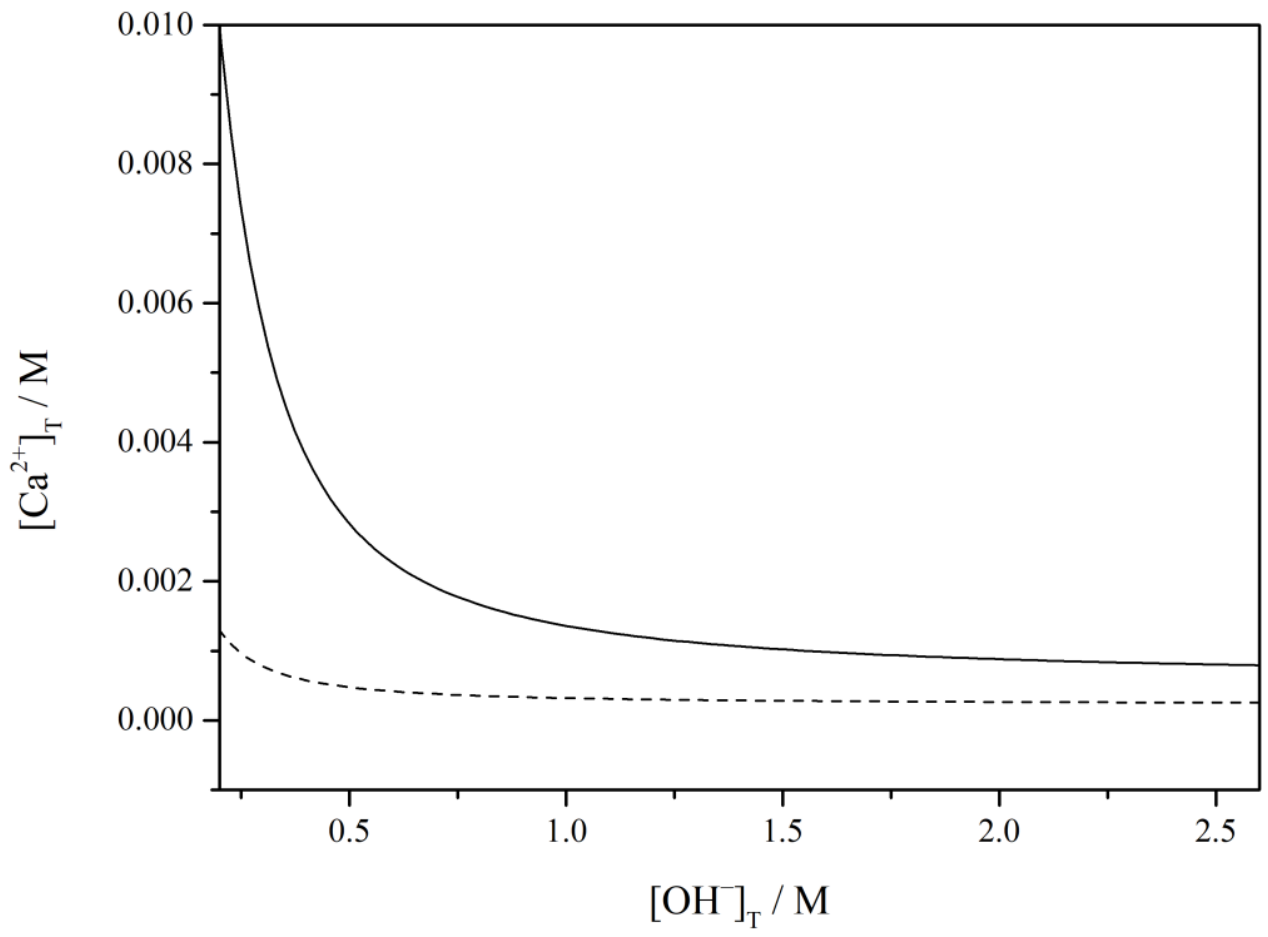

Figure 43. Maximum soluble calcium concentration $\left(\left[\mathrm{Ca}^{2+}\right]_{\mathrm{T}}\right)$ as a function of $\left[\mathrm{OH}^{-}\right]_{\mathrm{T}}$ in the absence of $\mathrm{Lac}^{-}$(dashed line) and in the presence of $\left[\mathrm{Lac}^{-}\right]_{\mathrm{T}}=0.50 \mathrm{M}$ (solid line) assuming heterogeneous equilibrium with respect to $\mathrm{Ca}(\mathrm{OH})_{2}(\mathrm{~s})$. 


\subsection{Calcium complexing properties of $\alpha$ - and $\beta$-ketoglutarate}

\subsubsection{Complexation of $\mathrm{Ca}^{2+}$ by $\alpha$ - and $\beta$-ketoglutarate in neutral medium}

In order to investigate the complexation equilibria between $\mathrm{Ca}^{2+}$ and $\alpha / \beta-\mathrm{Ket}^{2-}$ in (close to) neutral medium, Ca-ISE potentiometric titrations were performed at $\mathrm{T}=(25.0 \pm 0.1)^{\circ} \mathrm{C}$ and $\mathrm{I}=4.0 \mathrm{M}(\mathrm{NaCl})$. The titration curves obtained are shown in Fig. 44. It is seen that at a certain added titrant volume, $\left[\mathrm{Ca}^{2+}\right]$ shift to the lower values upon increasing the initial concentration of the ligand $\left(\left[\alpha / \beta-\mathrm{Ket}^{2-}\right]_{\mathrm{T}, 0}\right.$, that is) indicating that complex formation occurs. The three data sets were fitted simultaneously by minimizing the $F P$. For $\alpha-\mathrm{Ket}^{2-}$, the initial $F P=0.45 \log \left(\left[\mathrm{Ca}^{2+}\right]\right)$ unit could be decreased to 0.024 assuming the formation of the $\mathrm{Ca}(\alpha-\mathrm{Ket})^{0}$ complex with $\log \beta_{1,1}=1.15(2)$. $\beta_{1,1}$ is defined as

$$
\beta_{1,1}=\frac{\left[\mathrm{Ca}(\alpha-\mathrm{Ket})^{0}\right] \mathrm{c}^{\Theta}}{\left[\mathrm{Ca}^{2+}\right]\left[\alpha-\mathrm{Ket}^{2-}\right]}
$$

Similar measurements were performed for $\beta-\mathrm{Ket}^{2-}$ also, and during calculations the initial $F P=0.22$ could be decreased to 0.016 with the assumption of the $\mathrm{Ca}(\beta-\mathrm{Ket})^{0}$ complex with $\log \beta_{1,1}=0.78(2)$. Fig. 45 shows that these formation constants correspond to significant formation of both the $\mathrm{Ca}(\alpha-\mathrm{Ket})^{0}$ and $\mathrm{Ca}(\beta-\mathrm{Ket})^{0}$ species (up to $58 \%$ and $38 \%$, respectively).

The reason why the $\mathrm{Ca}(\alpha-\mathrm{Ket})^{0}$ complex proved to be somewhat more stable than the $\mathrm{Ca}(\beta-\mathrm{Ket})^{0}$ species can most probably be ascribed to the difference in the structure of the complexes. The possible binding sites in these species are one of the carboxylate groups and the oxo group (i.e. both $\alpha-\mathrm{Ket}^{2-}$ and $\beta-\mathrm{Ket}^{2-}$ act as bidentate ligands). Accordingly, in $\mathrm{Ca}(\alpha-\mathrm{Ket})^{0}$ a five-membered chelate ring is formed, while in $\mathrm{Ca}(\beta-\mathrm{Ket})^{0}$ a six-membered chelate ring is present (Fig. 46). Previously, it was suggested in several publications that complexes with five-membered chelate ring are usually more stable than those with six-membered chelate ring. ${ }^{[163,170-173]}$

The formation constant determined for $\mathrm{Ca}(\alpha-\mathrm{Ket})^{0}$ is in reasonable agreement with the previously reported value $(\log \beta=1.29 \text { at } \mathrm{I}=0.16 \mathrm{M})^{[52]}$, the difference is most likely due to the difference in the ionic strengths applied during the experiments. 


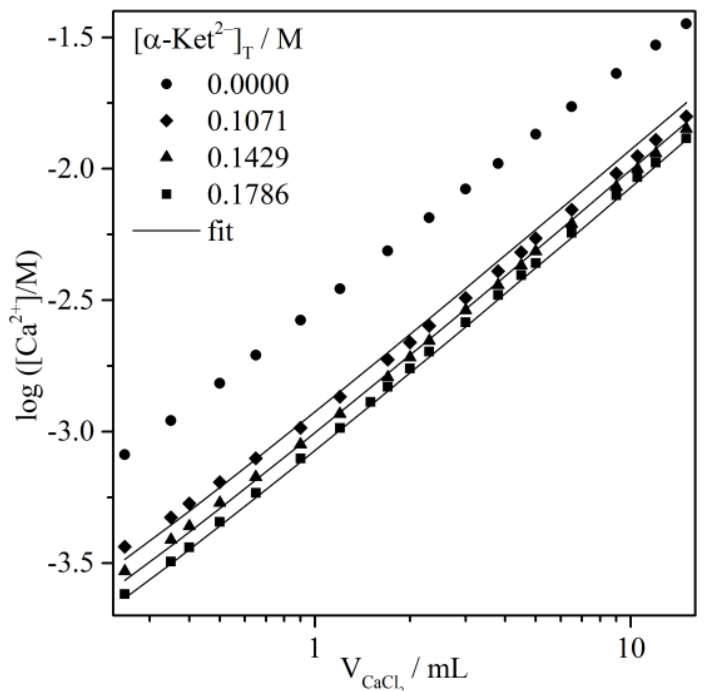

(a)

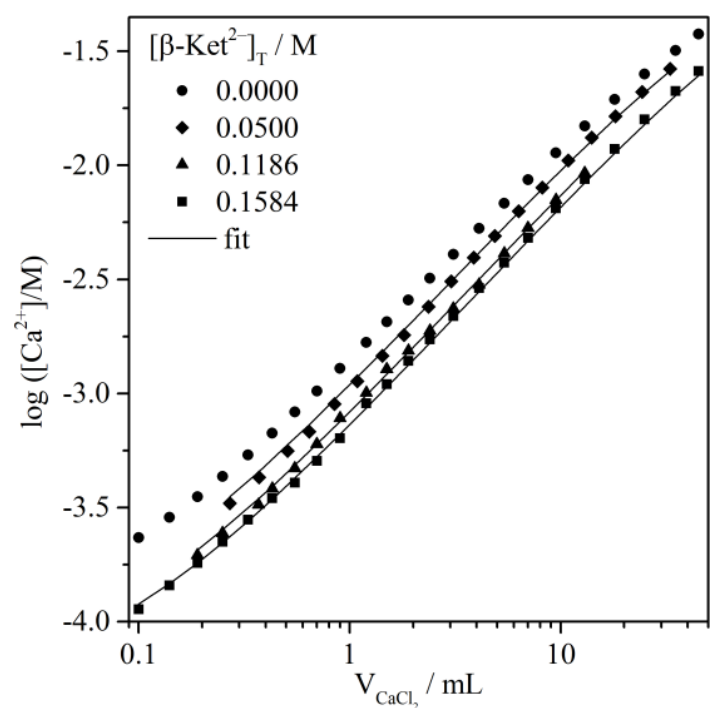

(b)

Figure 44. Ca-ISE potentiometric titration curves of solutions containing $\alpha-\mathrm{Ket}^{2-}$ (a) or $\beta-\mathrm{Ket}^{2-}$ (b) and $\mathrm{Ca}^{2+}$ in neutral medium as a function of the added titrant volume (log scale).

Experimental conditions: $\mathrm{T}=(25.0 \pm 0.1)^{\circ} \mathrm{C}, \mathrm{I}=4.0 \mathrm{M}(\mathrm{NaCl}), \mathrm{V}_{0}=70 \mathrm{~mL}$ (a) or $75 \mathrm{~mL}$ (b); $\left[\mathrm{Ca}^{2+}\right]_{\mathrm{T}, 0}=10^{-4} \mathrm{M}$, titrant: $\left[\mathrm{CaCl}_{2}\right]_{\mathrm{T}}=0.2015 \mathrm{M}(\mathrm{a})$ or $0.1002 \mathrm{M}(\mathrm{b})$. The initial concentrations of $\alpha / \beta-\mathrm{Ket}^{2-}$ concentrations are shown in the figure. Symbols and solid lines represent the experimental and calculated data, respectively.
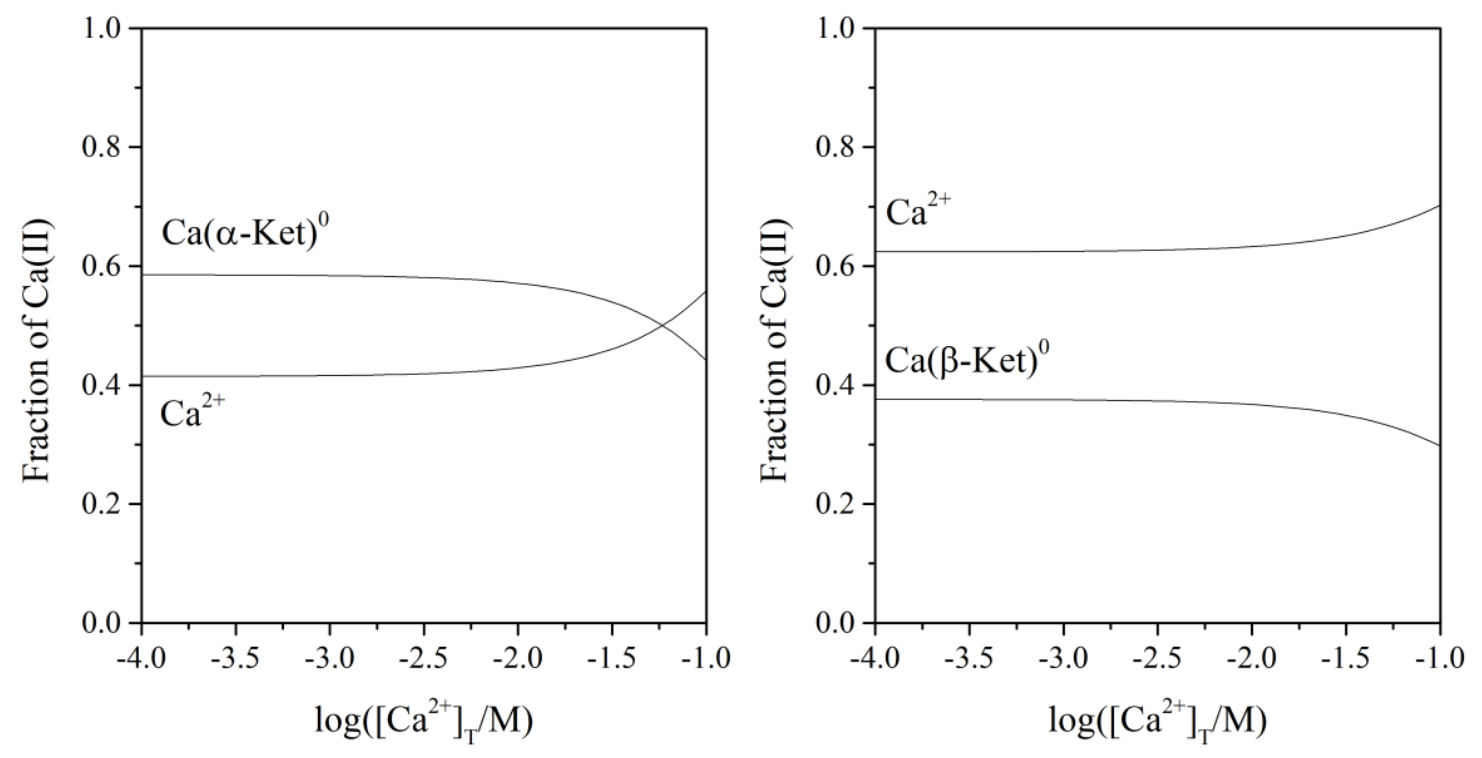

Figure 45. Distribution of $\mathrm{Ca}(\mathrm{II})$ among the various aqueous species in a solution containing $\left[\alpha / \beta-\mathrm{Ket}^{2-}\right]_{\mathrm{T}}=0.1 \mathrm{M}$ as a function of $\log \left(\left[\mathrm{Ca}^{2+}\right]_{\mathrm{T}} / \mathrm{M}\right)$. 


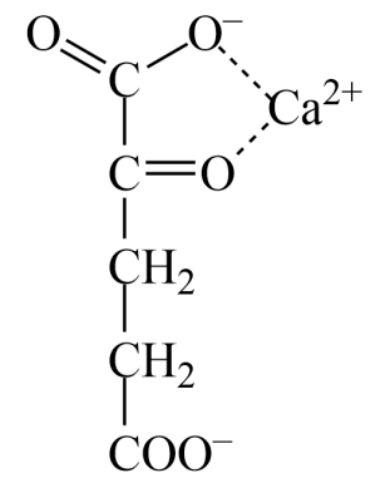

(a)

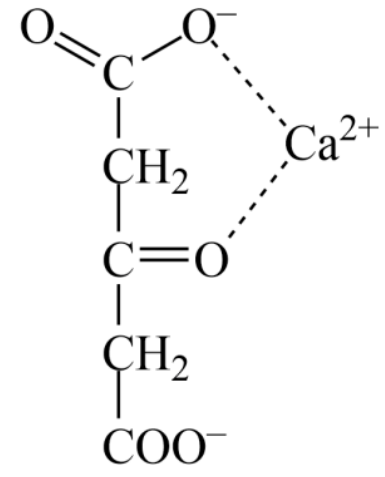

(b)

Fig. 46. Possible structure of the $\mathrm{Ca}(\alpha-\mathrm{Ket})^{0}$ and $\mathrm{Ca}(\beta-\mathrm{Ket})^{0}$ complexes.

\subsubsection{Deprotonation of $\alpha$ - and $\beta$-ketoglutarate in alkaline medium}

The ${ }^{1} \mathrm{H}$ NMR spectrum of $\alpha-\mathrm{Ket}^{2-}$ consists of two well-separated triplets corresponding to the two methylene groups (C3 and $\mathrm{C} 4$; for numbering, see Fig. 3 on page 8) of the ligand. On the increase of $\left[\mathrm{OH}^{-}\right]_{\mathrm{T}}$ in a solution containing $\left[\alpha-\mathrm{Ket}^{2-}\right]_{\mathrm{T}}=0.20 \mathrm{M}$, the peak of C3 (at around $2.8 \mathrm{ppm}$ ) significantly broadens and shifts upfield (Fig. 47) suggesting that deprotonation occurs on this methylene group, which leads to the formation of the enolate anion $\left((\alpha-\mathrm{Ket}) \mathrm{H}_{-1}{ }^{3-}\right.$, see Fig. 5 on page 9$)$.

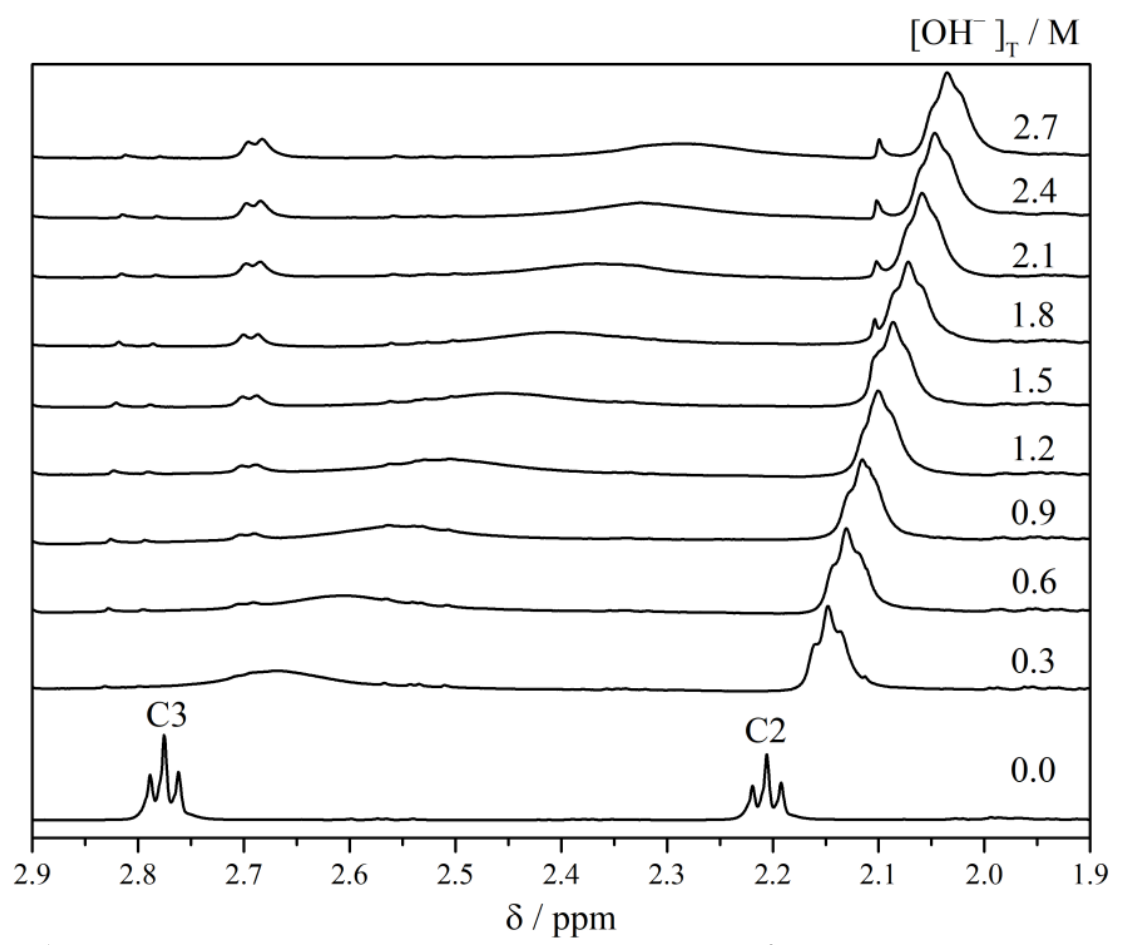

Figure 47. ${ }^{1} \mathrm{H}$ NMR spectra of solutions containing $\left[\alpha-\mathrm{Ket}^{2-}\right]_{\mathrm{T}}=0.20 \mathrm{M}$ and $\left[\mathrm{OH}^{-}\right]_{\mathrm{T}}=0.0$ $2.7 \mathrm{M} ; \mathrm{T}=(25 \pm 1)^{\circ} \mathrm{C}, \mathrm{I}=4.0 \mathrm{M}(\mathrm{NaCl})$. 
Furthermore, the significant line broadening indicates that the rate of the enolate formation is slow on the ${ }^{1} \mathrm{H}$ NMR time scale, the deprotonation of the methylene group is a relatively slow process compared to other deprotonation processes. As an example, the deprotonation rate constant of pyruvate ion in alkaline medium is estimated to be $5.7 \cdot 10^{-1} \mathrm{M}^{-1} \mathrm{~s}^{-1} \cdot{ }^{[173]}$

In order to determine the deprotonation constant of $\alpha-\mathrm{Ket}^{2-}$, UV spectrophotometric measurements were conducted. Upon increasing the $\mathrm{NaOH}$ concentration of a solution containing $\left[\alpha-\mathrm{Ket}^{2-}\right]_{\mathrm{T}}=1.00 \cdot 10^{-3} \mathrm{M}$, a new absorption band appears at $\lambda=263 \mathrm{~nm}$, which corresponds to the enolate form (Fig. 48). All spectra were fitted simultaneously by minimizing the $F P$. For these calculations, the ionic product of water, $\mathrm{pK}_{\mathrm{w}}$, was taken as 14.26 determined by Buckó, et al. at $\mathrm{T}=25^{\circ} \mathrm{C}$ and $\mathrm{I}=4.0 \mathrm{M}(\mathrm{NaCl}) .{ }^{[167]}$ The initial $F P=0.50$ absorbance unit decreased to 0.006 by assuming the formation of $\mathrm{KetH}_{-1}{ }^{3-}$ with $\mathrm{p} K_{\mathrm{a}}=15.17(1)$. The molar absorbance of the deprotonated species was found to be $\varepsilon=3800 \mathrm{M}^{-1} \mathrm{~cm}^{-1}$. The values determined for both the deprotonation constant and the molar absorbance are similr to the previously reported ones $\left(\mathrm{p} K_{\mathrm{a}}=15.8\right.$ and $\varepsilon=4800$ $\left.\mathrm{M}^{-1} \mathrm{~cm}^{-1}\right)^{[48]}$.

The enolate form, however, can undergo protonation at both the $\mathrm{O}^{-}$and the $\mathrm{CH}^{-}$ moieties and the protonated version can be deprotonated. Hence, the value for $\mathrm{p} K_{\mathrm{a}}$ presented here is composed of the deprotonation constants of the oxo $\left(\mathrm{p} K_{\mathrm{a}, \mathrm{oxo}}\right)$ and the enol $\left(\mathrm{p} K_{\mathrm{a}, \text { enol }}\right)$ forms of $\alpha-\mathrm{Ket}^{2-}$ :

$$
\frac{1}{K_{\mathrm{a}}}=\frac{\left[\alpha-\mathrm{Ket}^{2-}\right] \mathrm{c}^{\Theta}}{\left[\alpha-\mathrm{KetH}_{-1}{ }^{3-}\right]\left[\mathrm{H}^{+}\right]}=\frac{\left[\mathrm{oxo}^{2-}\right] \mathrm{c}^{\Theta}}{\left[\alpha-\mathrm{KetH}_{-1}{ }^{3-}\right]\left[\mathrm{H}^{+}\right]}+\frac{\left[\mathrm{enol}^{2-}\right] \mathrm{c}^{\Theta}}{\left[\alpha-\mathrm{KetH}_{-1}{ }^{3-}\right]\left[\mathrm{H}^{+}\right]}=\frac{1}{K_{\mathrm{a}, \text { oxo }}}+\frac{1}{K_{\mathrm{a}, \text { enol }}}
$$

For oxaloacetate, $\mathrm{p} K_{\mathrm{a}, \text { enol }}$ and $\mathrm{p} K_{\mathrm{a}, \text { oxo }}$ were found to be 12.4 and $13.2,{ }^{[48]}$ while for pyruvate $\mathrm{p} K_{\mathrm{a}, \text { enol }}=11.54$ and $\mathrm{p} K_{\mathrm{a}, \mathrm{oxo}}=16.58$ values were determined ${ }^{[174]}$ Using the relation given in Eq. 14., from these values $\mathrm{p} K_{\mathrm{a}}=13.26$ and 16.58 can be calculated for oxaloacetate and pyruvate, respectively, which means that for both of these ligands $\mathrm{p} K_{\mathrm{a}} \approx \mathrm{p} K_{\mathrm{a} \text {,oxo. The }}$ same can be assumed for $\alpha-\mathrm{Ket}^{2-}$ also, since its structure is similar to that of oxaloacetate. 


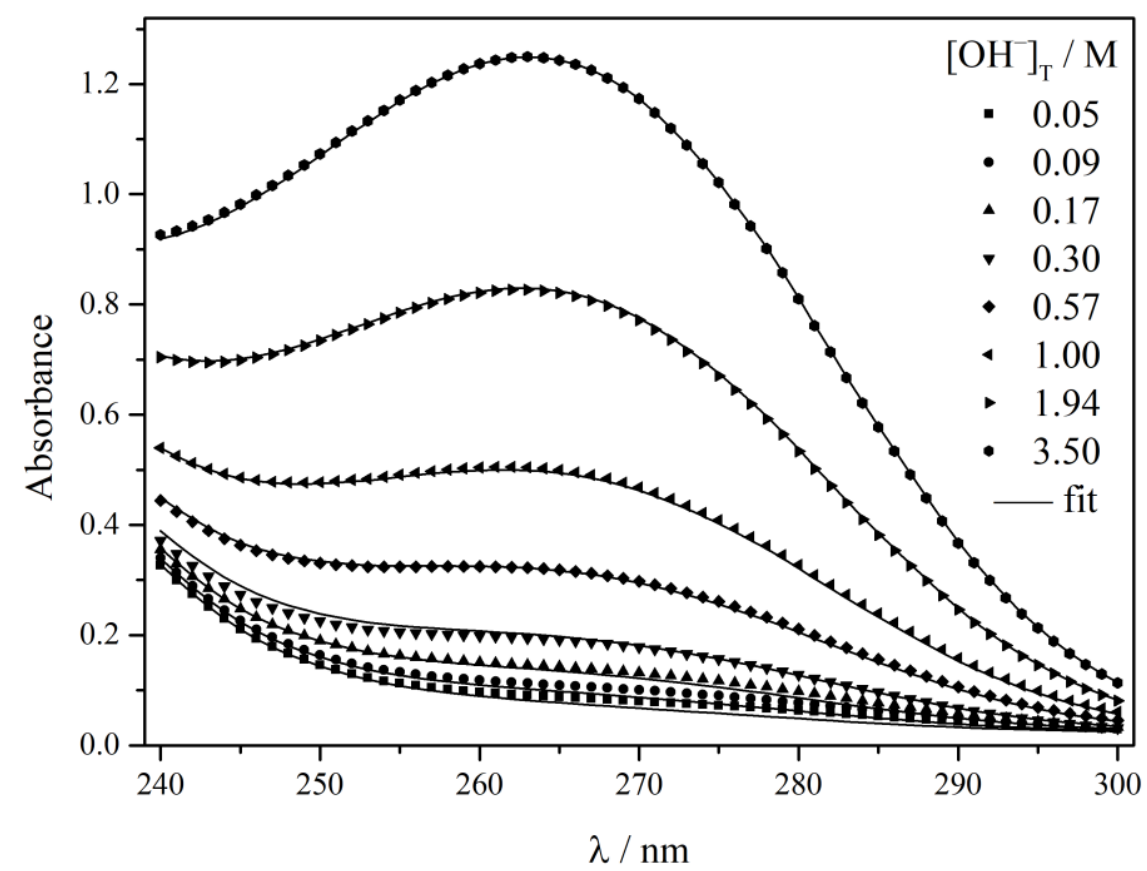

Figure 48. UV absorption spectra of solutions containing $\left[\alpha-\mathrm{Ket}^{2-}\right]_{\mathrm{T}}=0.001 \mathrm{M}$ and $\left[\mathrm{OH}^{-}\right]_{\mathrm{T}}=0.0-3.5 \mathrm{M} ; \mathrm{T}=(25 \pm 2)^{\circ} \mathrm{C}, \mathrm{I}=4.0 \mathrm{M}(\mathrm{NaCl})$. Symbols and solid lines represent the experimental and calculated data, respectively.

The ${ }^{1} \mathrm{H}$ NMR spectrum of $\beta-\mathrm{Ket}^{2-}$ consists of one singlet corresponding to the two chemically identical methylene groups ( $\mathrm{C} 2$ and $\mathrm{C} 4$, for numbering, see Fig. 3 on page 8) of the ligand. Fig. 49. demonstrates that by increasing $[\mathrm{NaOH}]_{\mathrm{T}}$ in a solution containing $\left[\beta-\mathrm{Ket}^{2-}\right]_{\mathrm{T}}=0.20 \mathrm{M}$, this singlet broadens and shifts upfield. In parallel, two new peaks appear corresponding to $\mathrm{C} 2$ (at around $3.7 \mathrm{ppm}$ ) and the deprotonated $\mathrm{C} 4$ (at around 3 $\mathrm{ppm})$. The systematic increase in the intensity of these peaks refers to the increasing extent of deprotonation. Similarly to $\alpha-\mathrm{Ket}^{2-}$, the significant broadening of the signals indicate that the rate of the enolate formation is slow on the ${ }^{1} \mathrm{H}$ NMR timescale.

Similarly to $\alpha-\mathrm{Ket}^{2-}$, UV spectrophotometric measurements were conducted in $\beta$-Ket ${ }^{2-}$-containing solutions to determine the deprotonation constant of the ligand. Upon addition of $\mathrm{NaOH}$ to a solution containing $\left[\beta-\mathrm{Ket}^{2-}\right]_{\mathrm{T}}=1.00 \cdot 10^{-4} \mathrm{M}$ or $2.00 \cdot 10^{-4} \mathrm{M}$ (Fig. $50 \mathrm{a}$ and b, respectively), a new peak appears at $\lambda=266 \mathrm{~nm}$ corresponding to the enolate form of the ligand $\left(\left(\beta-\mathrm{Ket}_{)}\right) \mathrm{H}_{-1}{ }^{3-}\right.$, that is). All spectra were fitted simultaneously, and the deprotonation constant of $\beta-\mathrm{Ket}^{2-}$ was determined to be $\mathrm{p} K_{\mathrm{a}}=14.41(1)$ with $F P=0.006$ absorbance unit. The molar absorbance of $(\beta-\mathrm{Ket}) \mathrm{H}_{-1}{ }^{3-}$ was found to be $\varepsilon=18600 \mathrm{M}^{-1} \mathrm{~cm}^{-1}$. Similarly to $\alpha-\mathrm{Ket}^{2-}$, this $\mathrm{p} K_{\mathrm{a}}$ value is composed of $\mathrm{p} K_{\mathrm{a}, \text { oxo }}$ and $\mathrm{p} K_{\mathrm{a} \text {,enol }}$ constants, although $\mathrm{p} K_{\mathrm{a}} \approx \mathrm{p} K_{\mathrm{a}, \text { oxo }}$ can be assumed based on structural similarities. 


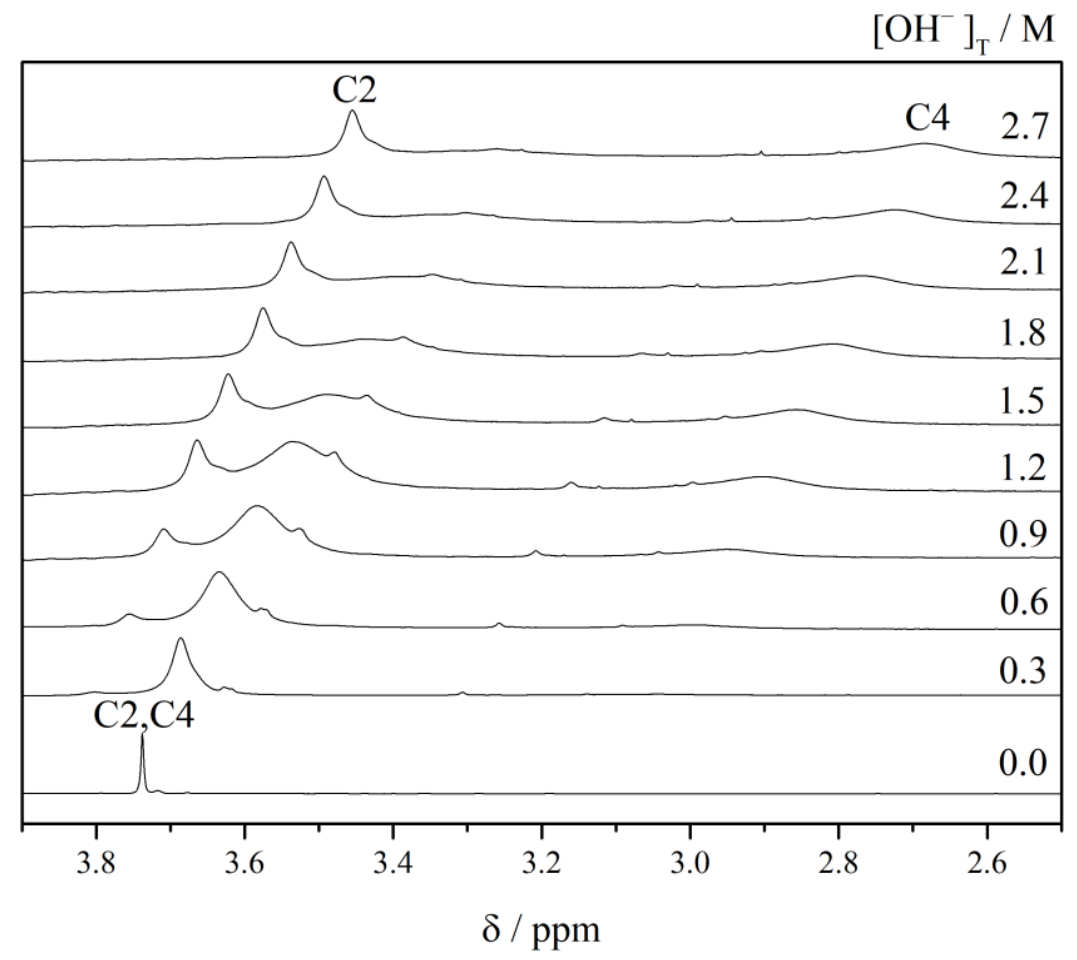

Figure 49. ${ }^{1} \mathrm{H}$ NMR spectra of solutions containing $\left[\beta-\mathrm{Ket}^{2-}\right]_{\mathrm{T}}=0.20 \mathrm{M}$ and $\left[\mathrm{OH}^{-}\right]_{\mathrm{T}}=0.0$ $2.7 \mathrm{M} ; \mathrm{T}=(25 \pm 1)^{\circ} \mathrm{C}, \mathrm{I}=4.0 \mathrm{M}(\mathrm{NaCl})$.

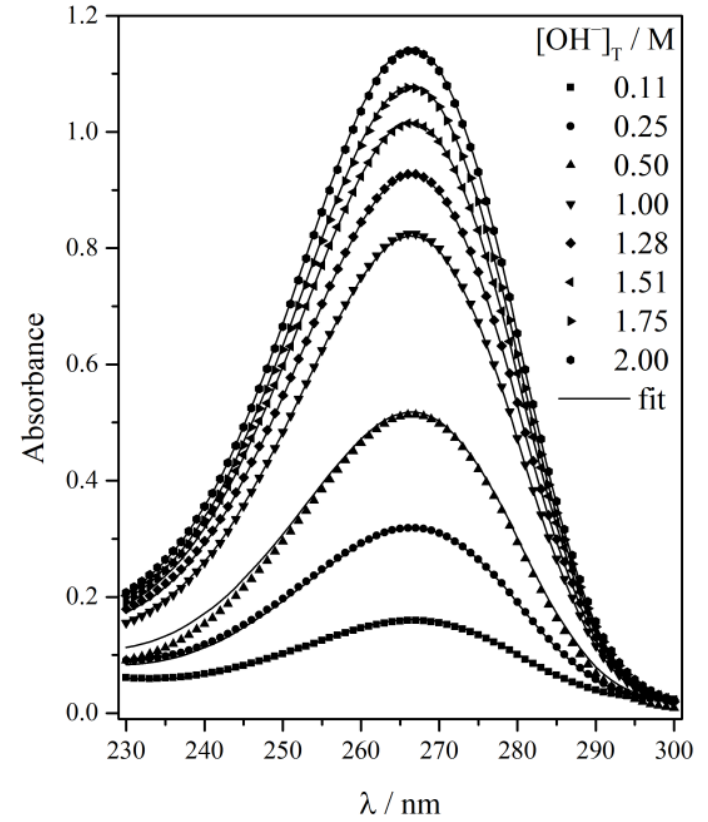

(a)

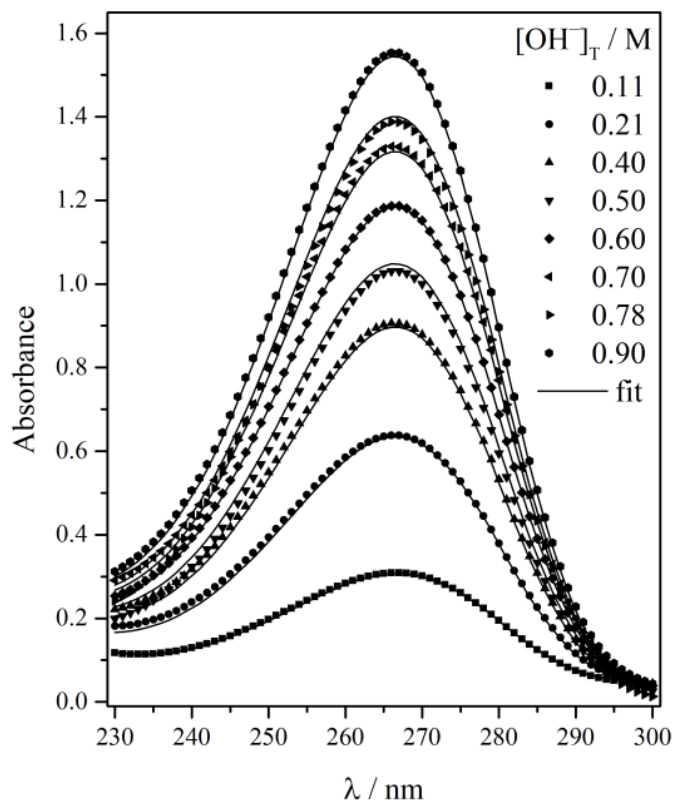

(b)

Figure 50. UV absorption spectra of solutions containing $\left[\beta-\mathrm{Ket}^{2-}\right]_{\mathrm{T}}=1.00 \cdot 10^{-4} \mathrm{M}$ and $\left[\mathrm{OH}^{-}\right]_{\mathrm{T}}=0.0-2.0 \mathrm{M}(\mathrm{a})$ or $2.00 \cdot 10^{-4} \mathrm{M}$ and $\left[\mathrm{OH}^{-}\right]_{\mathrm{T}}=0.0-0.90 \mathrm{M}(\mathrm{b}) ; \mathrm{T}=(25 \pm 2){ }^{\circ} \mathrm{C}, \mathrm{I}=4.0 \mathrm{M}$ $(\mathrm{NaCl})$. Symbols and solid lines denote the measured and calculated data, respectively.

It is demonstrated in Fig. 51 that the extent of deprotonation is $31 \%$ for $\alpha-\mathrm{Ket}^{2-}$ and $59 \%$ for $\beta-\mathrm{Ket}^{2-}$ under experimental conditions applied during the UV spectrophotometric experiments. 


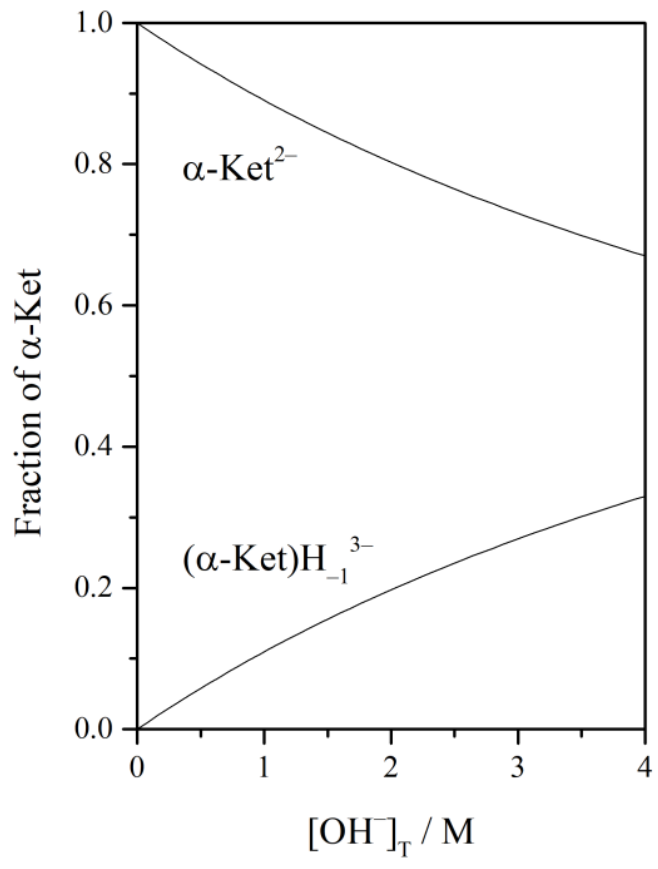

(a)

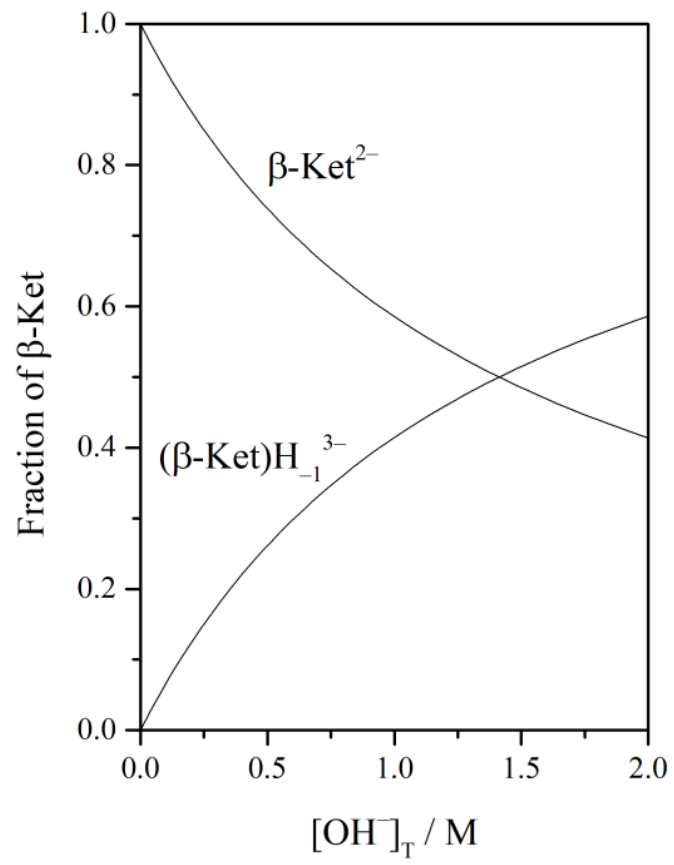

(b)

Figure 51. Distribution among the various aqueous species in a solution containing $\left[\alpha-\mathrm{Ket}^{2-}\right]_{\mathrm{T}}=$ $1.00 \cdot 10^{-3} \mathrm{M}$ (a) or $\left[\beta-\mathrm{Ket}^{2-}\right]_{\mathrm{T}}=1.00 \cdot 10^{-4} \mathrm{M}(\mathrm{b})$ as a function of $\left[\mathrm{OH}^{-}\right]_{\mathrm{T}}$.

The difference in the $\mathrm{p} K_{\mathrm{a}}$ values determined for $\alpha-\mathrm{Ket}^{2-}$ and $\beta-\mathrm{Ket}^{2-}$ is most probably due to the fact that in $(\beta-\mathrm{Ket}) \mathrm{H}_{-1}{ }^{3-}$ a more extended conjugation is present (through five bonds), while in ( $\alpha$-Ket) $\mathrm{H}_{-1}{ }^{3-}$ such extended conjugation is not possible due to the position of the enolate functional group (Fig. 52). Additionally, the more extended conjugation in $(\beta-\mathrm{Ket}) \mathrm{H}_{-1}{ }^{3-}$ is a plausible explanation for its higher molar absorbance.

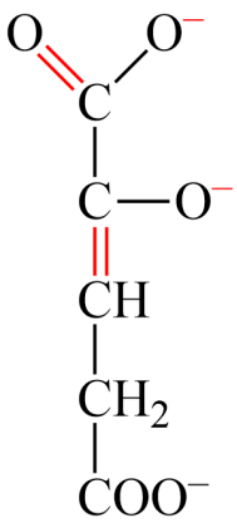

(a)

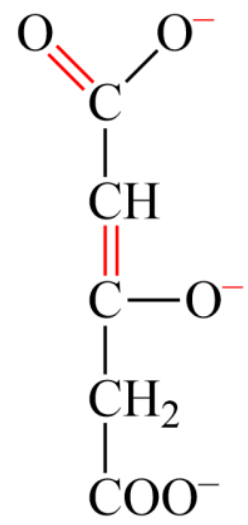

(b)

Figure 52. Structure of $(\alpha-\mathrm{Ket}) \mathrm{H}_{-1}{ }^{3-}$ (a) and $(\beta-\mathrm{Ket}) \mathrm{H}_{-1}{ }^{3-}$ (b) highlighting the bonds and charges involved in the conjugation. 


\subsubsection{Complexation of $\mathrm{Ca}^{2+}$ by $\alpha$ - and $\beta$-ketoglutarate in alkaline medium}

The effect of the addition of $\mathrm{Ca}^{2+}$ to an alkaline $\alpha-\mathrm{Ket}^{2-}$-containing solution was studied by ${ }^{1} \mathrm{H}$ NMR spectroscopy. Fig. 53. shows that by increasing $\left[\mathrm{Ca}^{2+}\right]_{\mathrm{T}}$ in a solution containing $\left[\alpha-\mathrm{Ket}^{2-}\right]_{\mathrm{T}}=0.010 \mathrm{M}$ and $\left[\mathrm{OH}^{-}\right]_{\mathrm{T}}=0.10 \mathrm{M}$, the ${ }^{1} \mathrm{H}$ NMR peak corresponding to $\mathrm{C} 3$ significantly broadens. This variation is similar to that observed during the deprotonation experiments (Fig. 47) suggesting that by adding $\mathrm{Ca}^{2+}$ to this solution the enolate species is formed. The upfield shift observed in the spectra in Fig. 47, however, is not seen in the spectra of the calcium-containing solutions indicating lower electron density on the ${ }^{1} \mathrm{H}$ nuclei. This finding proves that in parallel with deprotonation, the coordination of $\mathrm{Ca}^{2+}$ ions also takes place. Moreover, at this particular solution composition, the extent of deprotonation would only be $2 \%$ in the absence of $\mathrm{Ca}^{2+}$, thus, the spectral changes in the calcium-containing solutions are the result of complex formation between $\mathrm{Ca}^{2+}$ and $(\alpha-\mathrm{Ket}) \mathrm{H}_{-1}{ }^{3-}$.

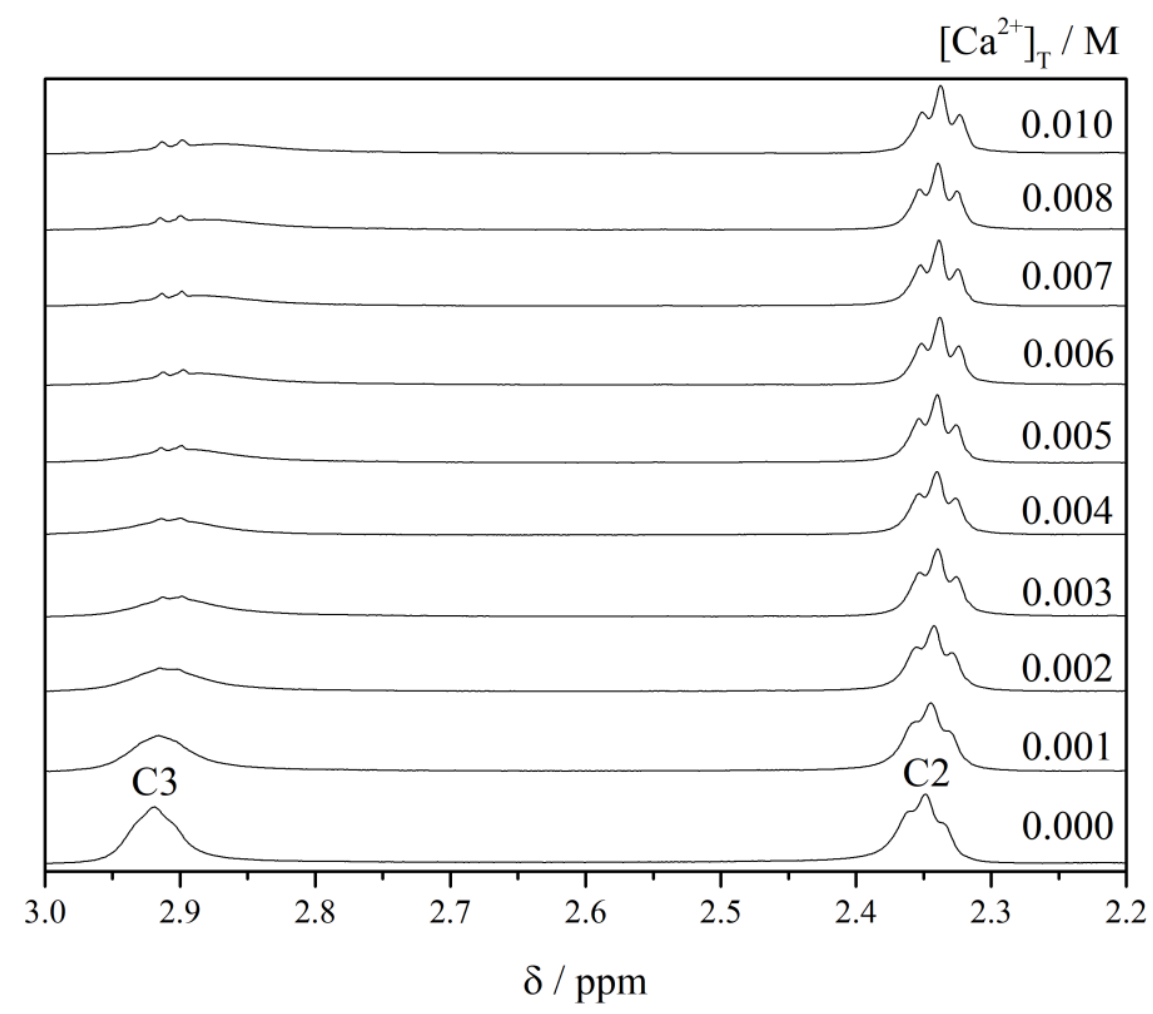

Figure 53. ${ }^{1} \mathrm{H}$ NMR spectra of solutions containing $\left[\alpha-\mathrm{Ket}^{2-}\right]_{\mathrm{T}}=0.010 \mathrm{M},\left[\mathrm{OH}^{-}\right]_{\mathrm{T}}=0.10 \mathrm{M}$ and $\left[\mathrm{Ca}^{2+}\right]_{\mathrm{T}}=0-0.01 \mathrm{M} ; \mathrm{T}=(25 \pm 1){ }^{\circ} \mathrm{C}, \mathrm{I}=4.0 \mathrm{M}(\mathrm{NaCl})$.

The calcium complexation was also studied by UV spectrophotometry. The amount of $\mathrm{Ca}^{2+}$ is limited by its solubility in $\mathrm{NaOH}$ because of the precipitation of $\mathrm{Ca}(\mathrm{OH})_{2}(\mathrm{~s})$. 
During the experiments, $0.01,0.015$ or $0.07 \mathrm{M} \mathrm{NaOH}$ concentrations were applied, which allowed to increase the concentration of calcium up to $0.18,0.1$ or $0.02 \mathrm{M}$, respectively, which exceeded the concentration of the ligand $(0.001-0.002 \mathrm{M})$.

The spectra of the calcium-containing solutions are shown in Figs. 54 and 55. During data processing, all spectra were fitted simultaneously in the wavelength range of $\lambda=240-300 \mathrm{~nm}$. The formation constants of $\mathrm{CaOH}^{+}$and $\mathrm{Ca}(\mathrm{OH})_{2}{ }^{0}$ were kept constant $(\log \beta=-13.92 \text { and }-27.64 \text {, respectively })^{[166]}$. The initial $F P=0.079$ absorbance unit could be decreased to 0.016 assuming the formation of the $\mathrm{Ca}(\alpha-\mathrm{Ket}) \mathrm{H}_{-1}{ }^{-}$complex, the corresponding formation constant was calculated to be $\log \beta_{1,1,-1}=-11.82(2)$. The systematic difference between the measured and calculated data were, however, still much larger than acceptable suggesting the formation of further complex(es). Therefore, several chemically meaningful compositions were tested, and the $F P$ could be further lowered to 0.0045 by assuming the formation of the $\mathrm{Ca}_{2}(\alpha-\mathrm{Ket}) \mathrm{H}_{-3}{ }^{-}$species beside the $\mathrm{Ca}(\alpha-\mathrm{Ket}) \mathrm{H}_{-1}{ }^{-}$complex. The respective formation constants were found to be $\log \beta_{1,1,-1}=-11.91(2)$ and $\log \beta_{2,1,-3}=-36.10(6)$. The formation of the complex with 2:1:-3 composition is somewhat unexpected, its presence can be observed only at the highest $\mathrm{NaOH}$ concentrations (see the distribution diagram in Fig. 56). Since it is unlikely that $(\alpha-\mathrm{Ket}) \mathrm{H}_{-1}{ }^{3-}$ undergoes a second deprotonation step, $\mathrm{Ca}_{2}(\alpha-\mathrm{Ket}) \mathrm{H}_{-3}{ }^{-}$is most likely a calcium hydroxido-enolate complex, in which one $\mathrm{OH}^{-}$ion is bound to each calcium ion.
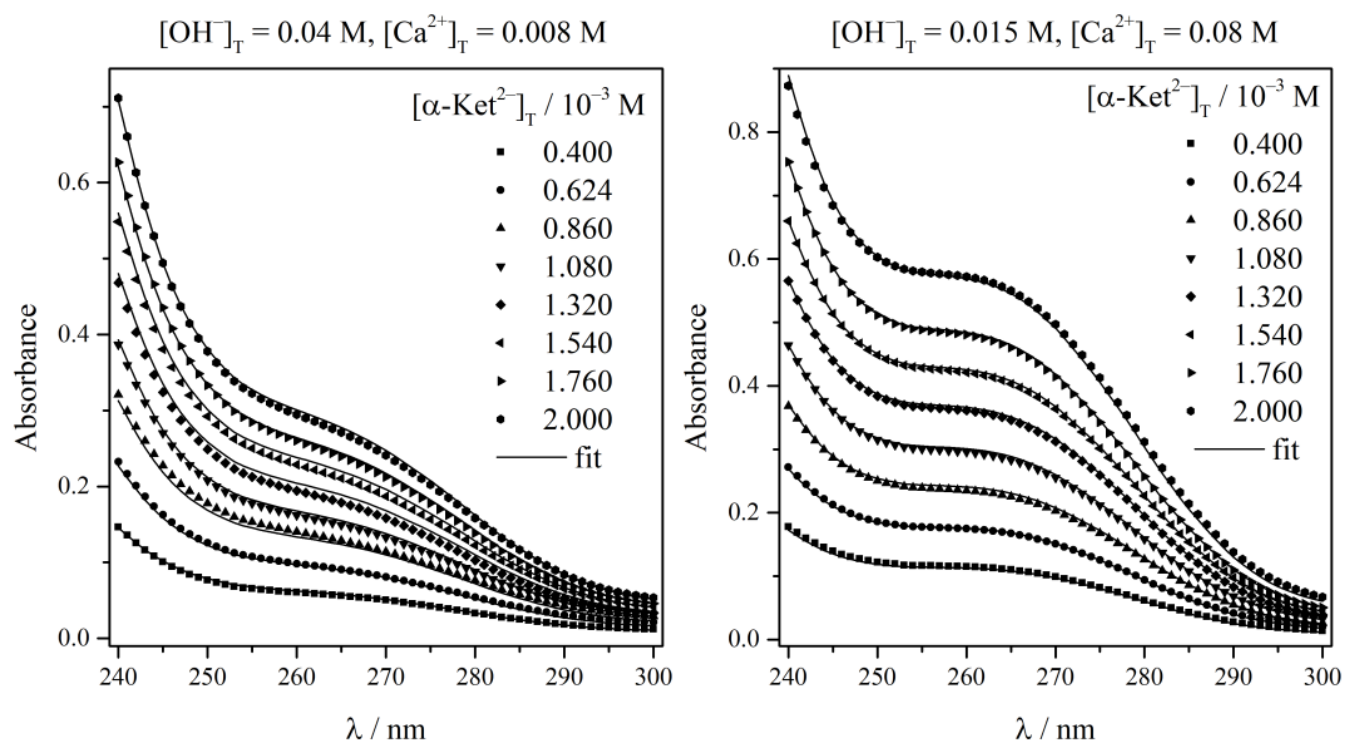

Figure 54. UV absorption spectra of solutions containing constant amount of $\mathrm{Ca}^{2+}$ and $\mathrm{OH}^{-}$and increasing amount of $\alpha-\mathrm{Ket}^{2-}$ (the exact solution compositions are shown in each figure), $\mathrm{T}=(25 \pm 2)^{\circ} \mathrm{C}, \mathrm{I}=4.0 \mathrm{M}(\mathrm{NaCl})$. Symbols and solid lines represent the measured and fitted data, respectively. 

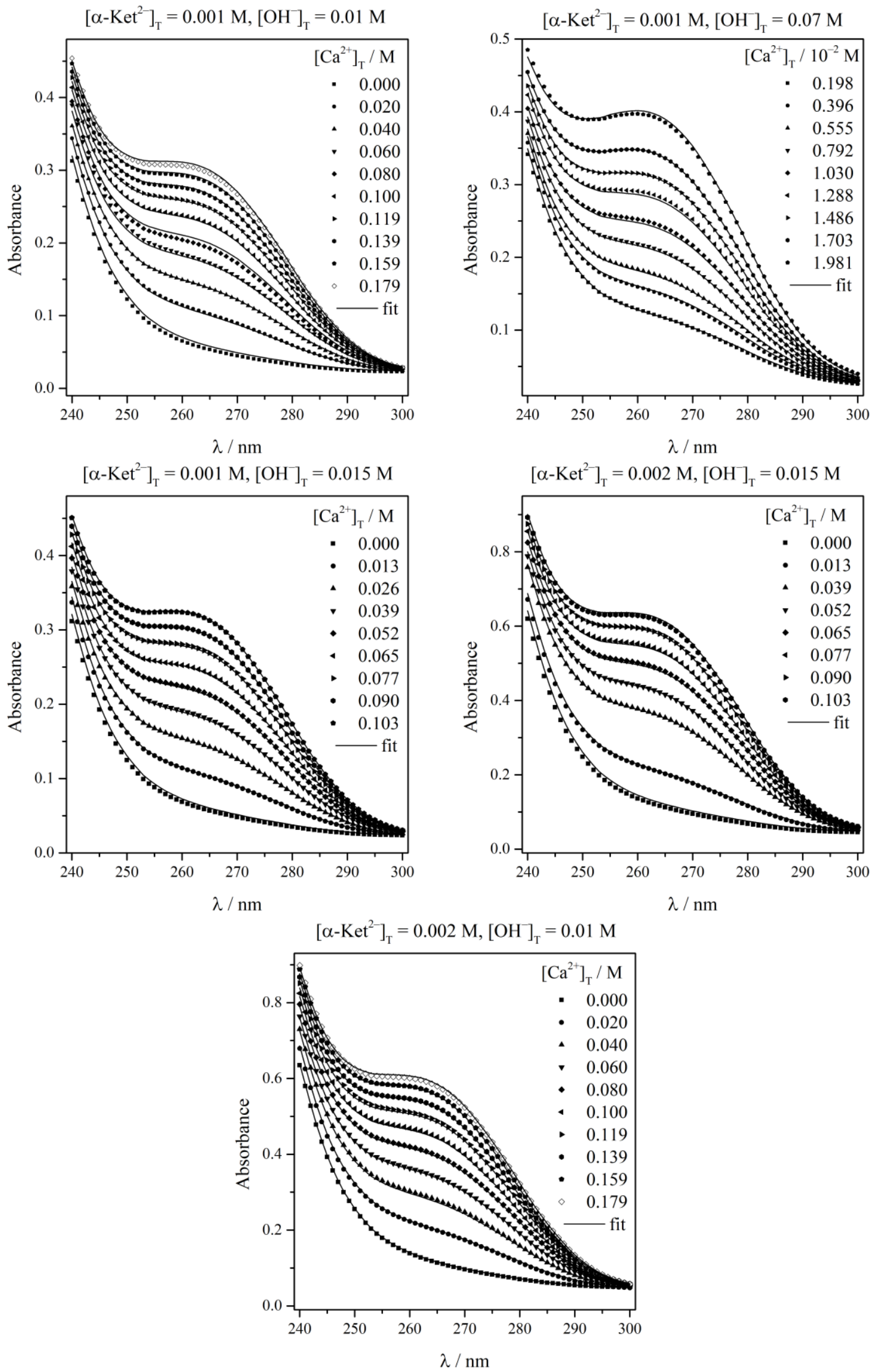

Figure 55. UV absorption spectra of solutions containing constant amount of $\alpha-\mathrm{Ket}^{2-}$ and $\mathrm{OH}^{-}$ and increasing amount of $\mathrm{Ca}^{2+}$ (the exact solution compositions are shown in each figure), $\mathrm{T}=(25 \pm 2){ }^{\circ} \mathrm{C}, \mathrm{I}=4.0 \mathrm{M}(\mathrm{NaCl})$. Symbols and solid lines represent the measured and fitted data, respectively. 


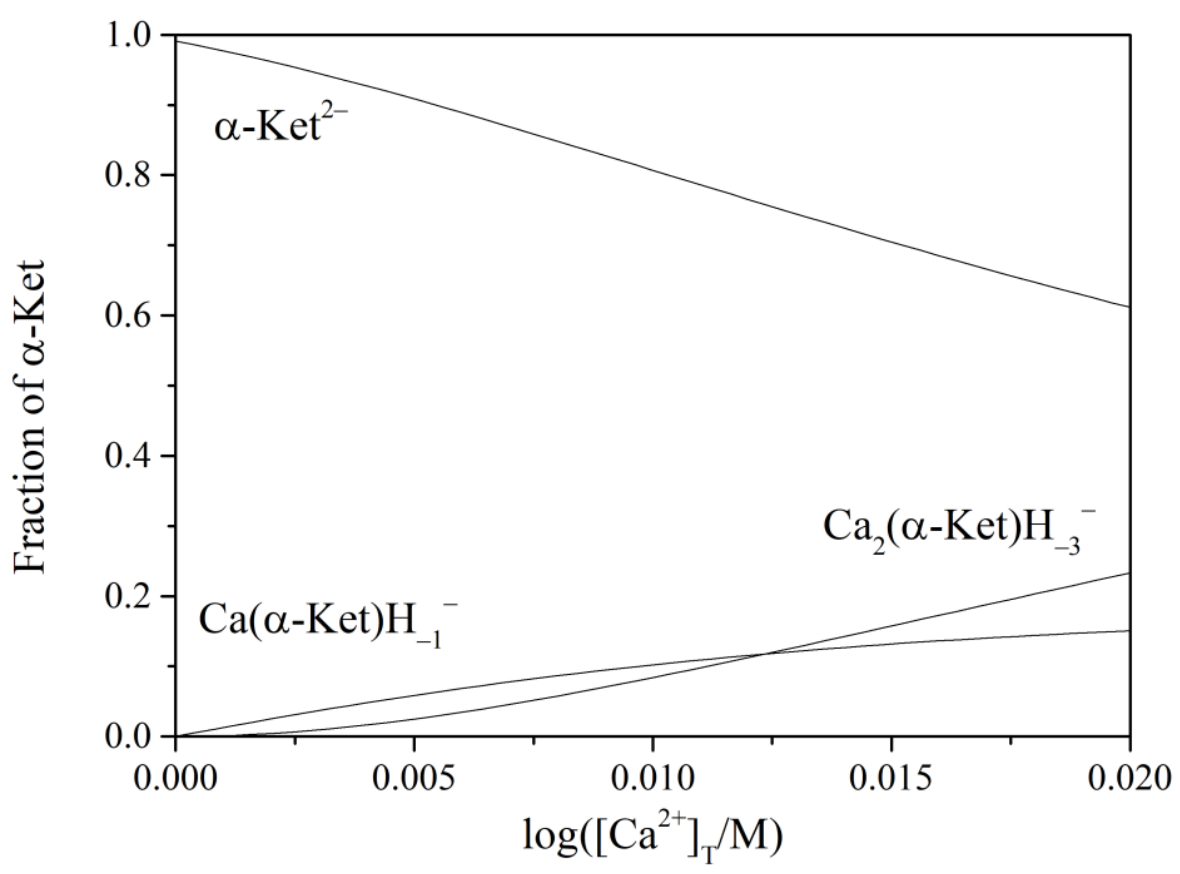

Figure 56. Distribution of $\alpha$-Ket among the various aqueous species in a solution containing $\left[\alpha-\mathrm{Ket}^{2-}\right]_{\mathrm{T}}=0.001 \mathrm{M}$ and $\left[\mathrm{OH}^{-}\right]_{\mathrm{T}}=0.07 \mathrm{M}$ as a function of $\log \left(\left[\mathrm{Ca}^{2+}\right]_{\mathrm{T}} / \mathrm{M}\right)$.

Analogous measurements were performed for the $\beta-\mathrm{Ket}^{2-}$-containing solutions. By increasing $\left[\mathrm{Ca}^{2+}\right]_{\mathrm{T}}$ in a solution containing $\left[\beta-\mathrm{Ket}^{2-}\right]_{\mathrm{T}}=0.010 \mathrm{M}$ and $\left[\mathrm{OH}^{-}\right]_{\mathrm{T}}=0.10 \mathrm{M}$, a new peak appears at around $\delta=3.15 \mathrm{ppm}$ (Fig. 57). This variation is similar to that observed for deprotonation (Fig. 49) suggesting the formation of the enolate form. A significant upfield shift is seen for both peaks ( $c a .3 .76$ and $3.15 \mathrm{ppm}$ ) compared to those observed for deprotonation ( $\mathrm{ca} .3 .5$ and $2.7 \mathrm{ppm}$ ) indicating that the electron density is lower on the ${ }^{1} \mathrm{H}$ nuclei in the calcium-containing systems due to complex formation. Furthermore, under these experimental conditions the extent of deprotonation would only be $6 \%$ in the absence of $\mathrm{Ca}^{2+}$ attesting that complex formation occurs between $\mathrm{Ca}^{2+}$ and $(\beta-\mathrm{Ket}) \mathrm{H}_{-1}{ }^{3-}$. 


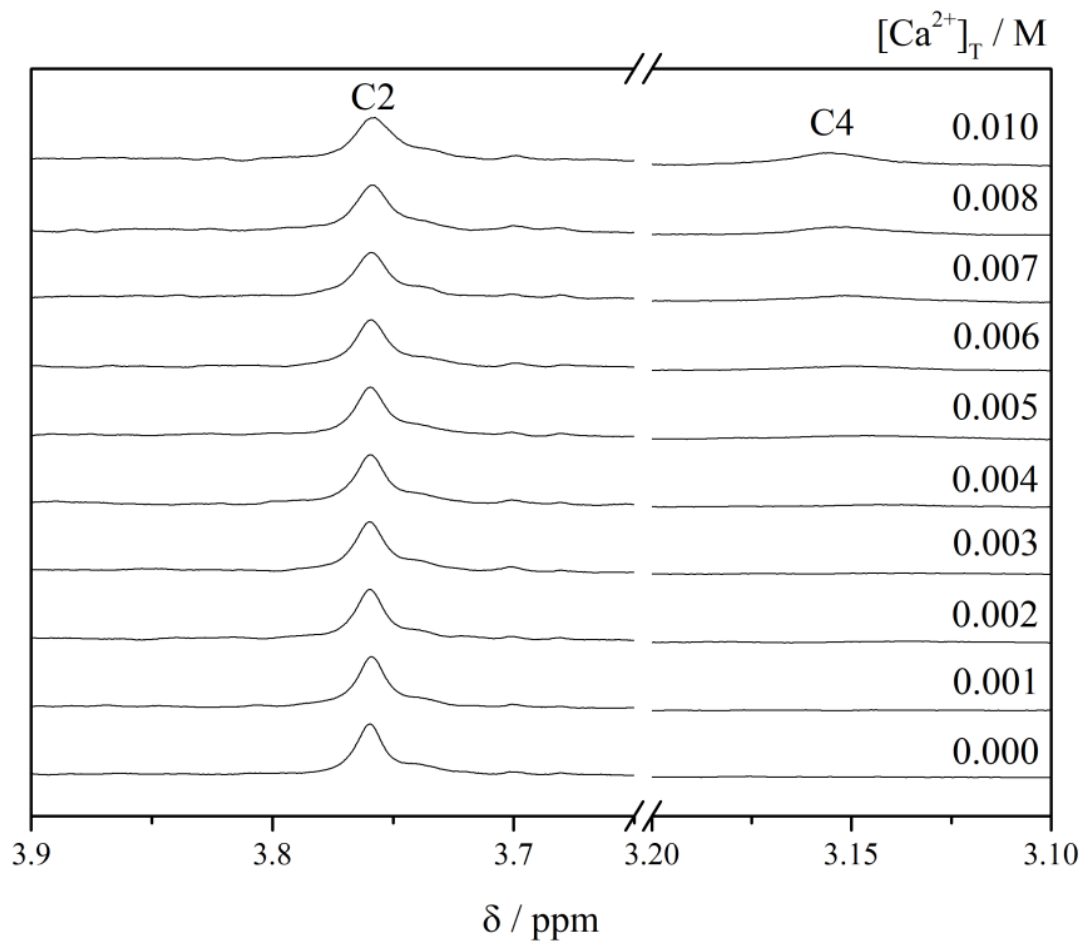

Figure 57. ${ }^{1} \mathrm{H}$ NMR spectra of solutions containing $\left[\beta-\mathrm{Ket}^{2-}\right]_{\mathrm{T}}=0.010 \mathrm{M},\left[\mathrm{OH}^{-}\right]_{\mathrm{T}}=0.10 \mathrm{M}$ and $\left[\mathrm{Ca}^{2+}\right]_{\mathrm{T}}=0-0.01 \mathrm{M} ; \mathrm{T}=(25 \pm 1)^{\circ} \mathrm{C}, \mathrm{I}=4.0 \mathrm{M}(\mathrm{NaCl})$.

In order to determine the composition and formation constant of the complex(es) forming in the $\beta-\mathrm{Ket}^{2-}$-containing solutions, UV spectrophotometric measurements were conducted. Several solution sets were prepared in which $\left[\beta-\mathrm{Ket}^{2-}\right]_{\mathrm{T}}$ and $\left[\mathrm{OH}^{-}\right]_{\mathrm{T}}$ was held constant while $\left[\mathrm{Ca}^{2+}\right]_{\mathrm{T}}$ was systematically increased (Fig. 58). During data processing, the absorbance values were fitted as a function of $\left[\mathrm{Ca}^{2+}\right]_{\mathrm{T}}$ by minimizing the $F P$. Additionally, the formation constants of $\mathrm{CaOH}^{+}$and $\mathrm{Ca}(\mathrm{OH})_{2}$ were kept constant $(\log \beta=-13.92 \text { and }-27.64 \text {, respectively })^{[166]}$. The initial $F P=0.21$ absorbance unit decreased to 0.016 by assuming the formation of the $\mathrm{Ca}(\beta-\mathrm{Ket}) \mathrm{H}_{-1}{ }^{-}$complex with $\log \beta_{1,1,-1}=-11.80(1)$, the difference between the measured and calculated data, however, was unacceptably large. After screening several chemically meaningful compositions, the most remarkable decrease in FP (to 0.006) was achieved by including $\mathrm{Ca}_{2}\left(\beta-\mathrm{Ket}^{2-}\right) \mathrm{H}_{-1}{ }^{+}$ to the model. The thus obtained formation constants are $\log \beta_{1,1,-1}=-11.58(1)$ and $\log \beta_{2,1,-1}=-10.80(3)$ for $\mathrm{Ca}(\beta-\mathrm{Ket}) \mathrm{H}_{-1}{ }^{-}$and $\mathrm{Ca}_{2}\left(\beta-\mathrm{Ket}^{2-}\right) \mathrm{H}_{-1}{ }^{+}$, respectively. Both these complexes most likely involve a $(\beta-\mathrm{Ket}) \mathrm{H}_{-1}{ }^{3-}$ ligand. Fig. 59 shows that these species are formed in significant quantity. 

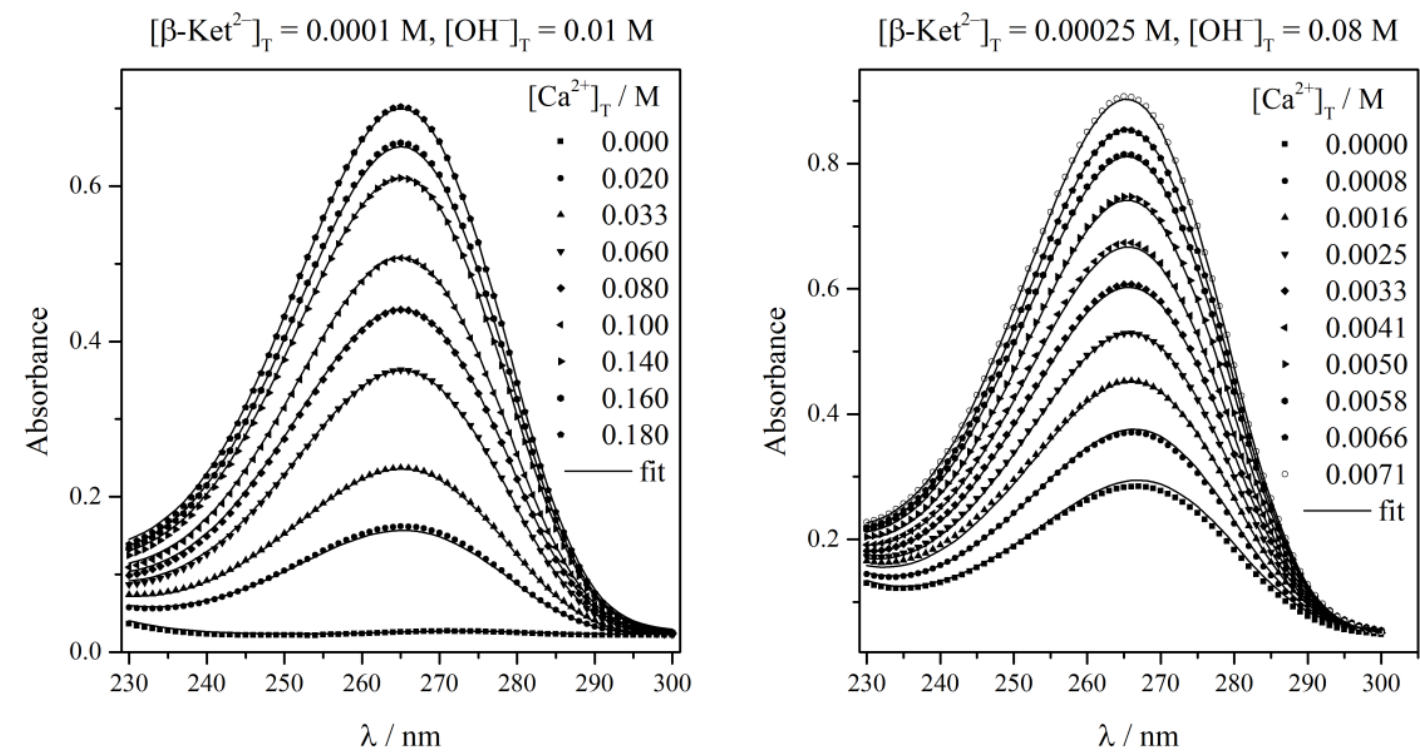

$\left[\beta-\mathrm{Ket}^{2-}\right]_{\mathrm{T}}=0.000125 \mathrm{M},[\mathrm{OH}]_{\mathrm{T}}=0.01 \mathrm{M}$
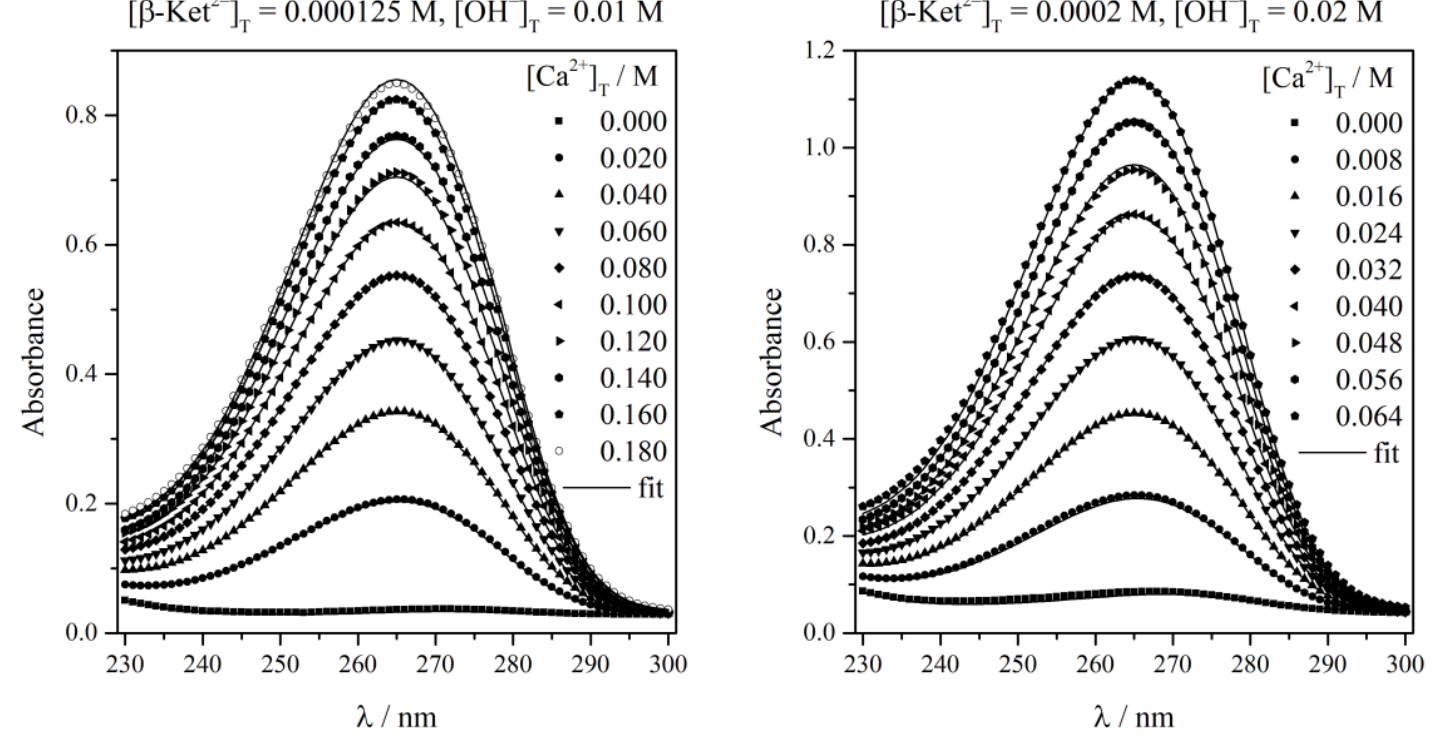

$\left[\beta-\mathrm{Ket}^{2}\right]_{\mathrm{T}}=0.00015 \mathrm{M},[\mathrm{OH}]_{\mathrm{T}}=0.04 \mathrm{M}$
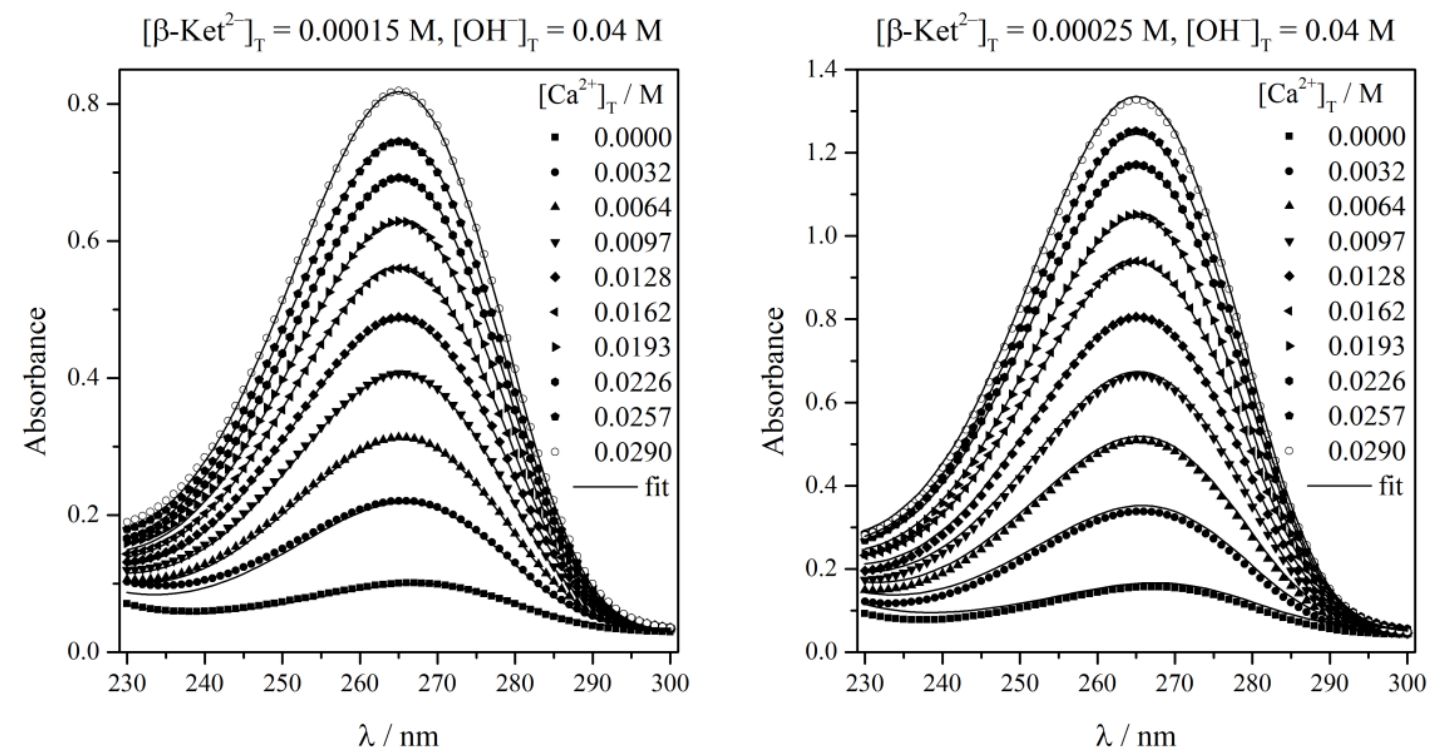

Figure 58. UV absorption spectra of solutions containing constant amount of $\beta-\mathrm{Ket}^{2-}$ and $\mathrm{OH}^{-}$ and increasing amount of $\mathrm{Ca}^{2+}$ (the exact solution compositions are shown in each figure), $\mathrm{T}=(25 \pm 2){ }^{\circ} \mathrm{C}, \mathrm{I}=4.0 \mathrm{M}(\mathrm{NaCl})$. Symbols and solid lines represent the measured and fitted data, respectively. 


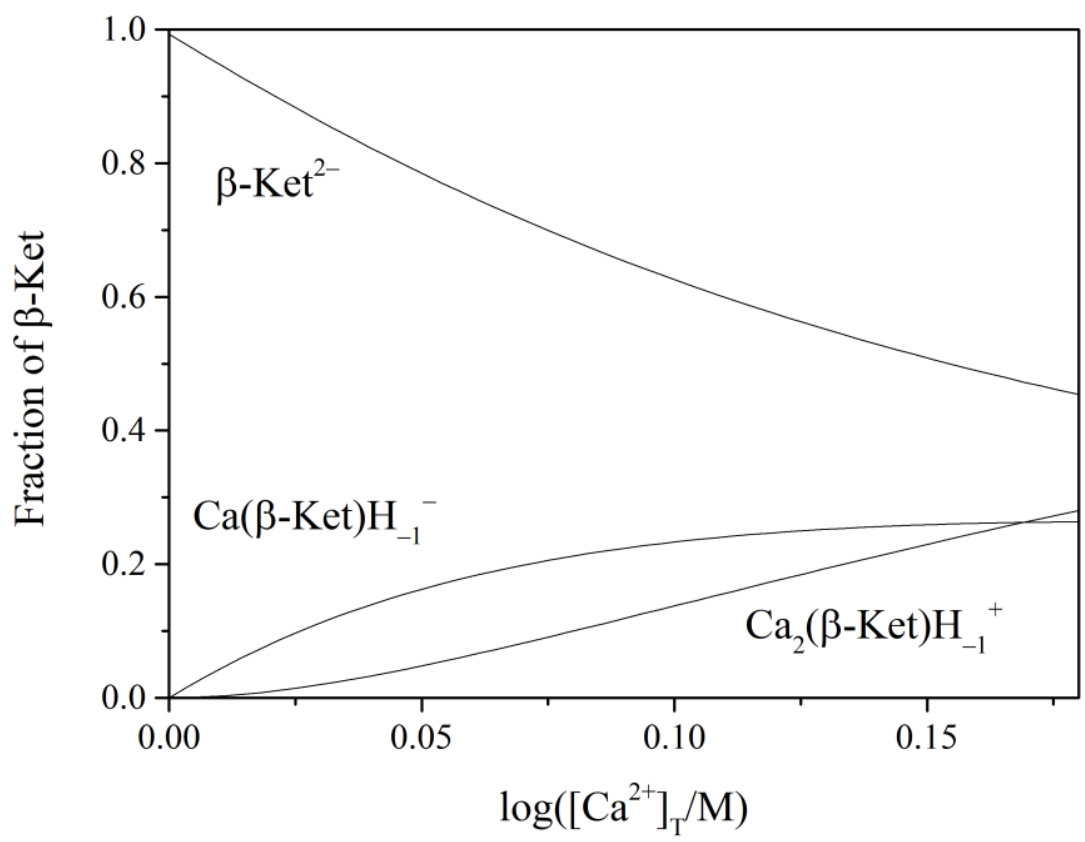

Figure 59. Distribution of $\beta$-Ket among the various aqueous species in a solution containing $\left[\beta-\mathrm{Ket}^{2-}\right]_{\mathrm{T}}=1.00 \cdot 10^{-4} \mathrm{M}$ and $\left[\mathrm{OH}^{-}\right]_{\mathrm{T}}=0.01 \mathrm{M}$ as a function of $\log \left(\left[\mathrm{Ca}^{2+}\right]_{\mathrm{T}} / \mathrm{M}\right)$.

It is interesting to note that the difference in the formation constants of the 1:1:-1 complexes $\left(\log \beta_{1,1,-1}=-11.91\right.$ for $\mathrm{Ca}(\alpha-\mathrm{Ket}) \mathrm{H}_{-1}{ }^{-}$and -11.58 for $\left.\mathrm{Ca}(\beta-\mathrm{Ket}) \mathrm{H}_{-1}{ }^{-}\right)$reflects the difference in the $\mathrm{p} K_{\mathrm{a}}$ values of the ligands. Conversely, the formation constant belonging to the direct association reaction between $\mathrm{Ca}^{2+}$ and the deprotonated ligand (i.e. for the reaction $\left.\mathrm{Ca}^{2+}+(\alpha / \beta-\mathrm{Ket}) \mathrm{H}_{-1}{ }^{3-} \rightleftharpoons \mathrm{Ca}(\alpha / \beta-\mathrm{Ket}) \mathrm{H}_{-1}{ }^{-}\right), \log K_{1,1,-1}=3.26$ for $\mathrm{Ca}(\alpha-$ Ket $) \mathrm{H}_{-1}{ }^{-}$and 2.83 for $\mathrm{Ca}(\beta-\mathrm{Ket}) \mathrm{H}_{-1}{ }^{-}$, supports the notion that $(\alpha-\mathrm{Ket}) \mathrm{H}_{-1}{ }^{3-}$ is a stronger base than $(\beta-\mathrm{Ket}) \mathrm{H}_{-1}{ }^{3-}$.

It is worth mentioning that the stability of the $1: 1:-1$ complexes is significantly higher than that of the 1:1 complexes forming in neutral medium suggesting the formation of stronger chelate rings. Moreover, the $\log \beta_{1,1,-1}$ values determined for $\mathrm{Ca}(\alpha-\mathrm{Ket}) \mathrm{H}_{-1}{ }^{-}$ and $\mathrm{Ca}(\beta-\mathrm{Ket}) \mathrm{H}_{-1}{ }^{-}$are very similar to those of the $\mathrm{CaIsaH}_{-1}{ }^{0}$ or $\mathrm{CaGlucH}_{-1}{ }^{0}$ species, both of which contain a deprotonated $\mathrm{OH}$ group. Therefore, calcium is proved to be able to induce the deprotonation of the methylene group of $\alpha-\mathrm{Ket}^{2-}$ and $\beta-\mathrm{Ket}^{2-}$ forming calcium enolato complexes. To the best of our knowledge, such calcium enolato species have not been described in the literature. 


\section{Conclusions}

In the present work, a comprehensive study was undertaken on the calcium complexing behaviour of selected hydroxy- and oxocarboxylates relevant to nuclear waste disposal. Under the highly alkaline conditions prevailing in low and intermediate level radioactive waste repositories, the presence of small molecular metal chelators are considered to have significant impact on the mobilization of radionuclides. The ligand, present in the largest quantity in these repositories, is $\alpha$-D-isosaccharinate (Isa ${ }^{-}$), however, D-gluconate $\left(\mathrm{Gluc}^{-}\right)$is frequently used as its structural and functional model. In these systems calcium is present in significantly higher quantities than actinides or lanthanides, hence it can influence the complexing ability of the ligands towards the radioactive metal ions either by forming complexes with them or by causing their precipitation in the form of sparingly soluble salts. Therefore, investigating the complexation of these ligands with calcium in highly alkaline medium is important with regard to environmental protection.

In neutral medium, Isa ${ }^{-}$, lactate $\left(\mathrm{Lac}^{-}\right), \alpha$-ketoglutarate $\left(\alpha-\mathrm{Ket}^{2-}\right)$ and $\beta$-ketoglutarate $\left(\beta-\mathrm{Ket}^{2-}\right)$ were found to form weak complexes with calcium.

Regarding Isa ${ }^{-}$, the formation of the $\mathrm{CaIsa}^{+}$complex was detected, its stability was found to be similar to that of $\mathrm{CaGluc}^{+}$. In the $\mathrm{Gluc}^{-}$-containing solutions, however, the presence of the $\mathrm{CaGluc}_{2}{ }^{0}$ complex was previously shown. Analogous complex with 1:2 composition was not detected in the Isa ${ }^{-}$-containing solutions. This difference is most probably due to the differences in the structure of the two ligands, Gluc ${ }^{-}$being more flexible than Isa ${ }^{-}$. Additionally, in the structure of $\mathrm{Isa}^{-}$, there is a hydrophobic motif not present in $\mathrm{Gluc}^{-}$. The structures of these complexes were optimized by molecular modelling calculations. For $\mathrm{CaIsa}^{+}$, two coordination isomers were found, $\mathrm{Isa}^{-}$acts as a tridentate ligand in both. Additionally, four water molecules are coordinated to calcium in both cases, the coordination number being seven. For $\mathrm{CaGluc}^{+}$, also two coordination isomers were suggested. In these complexes, however, Gluc ${ }^{-}$is a bidentate ligand, and the coordination number of calcium is six.

The solid phases precipitating from neutral solutions containing $\mathrm{Ca}^{2+}$ and $\mathrm{Isa}^{-}$or Gluc $^{-}$were also examined, i.e., single crystals of calcium isosaccharinate and calcium gluconate were prepared, and their single crystal structures were determined. For CaIsa2, a structure was determined previously in 1968, however, the use of synchrothron source 
in this work provided data of sufficient quality to improve the structure reported previously (i.e., to determine the location of the hydroxy hydrogen sites). Both $\mathrm{CaIsa}_{2}$ and $\mathrm{CaGluc}_{2} \cdot \mathrm{H}_{2} \mathrm{O}$ have non-centrosymmetric orthorhombic structures comprised of coordination polymers parallel to the $a$ axis. The most significant difference in the two structures is that in the $\mathrm{CaGluc}_{2} \cdot \mathrm{H}_{2} \mathrm{O}$ structure adjacent metal centres are linked by $\mu$-oxo bridges, while in $\mathrm{CaIsa}_{2}$ adjacent metal centres are spanned by two $\mathrm{Isa}^{-}$ligands. Moreover, the calcium ion is coordinated eightfold in CaIsa2, while it is coordinated ninefold in $\mathrm{CaGluc}_{2} \cdot \mathrm{H}_{2} \mathrm{O}$. Additionally, the two structures were shown to have very different hydrogen bonding networks and packing arrangements.

In the $\mathrm{Lac}^{-}$-containing solutions, the presence of the $\mathrm{CaLac}^{+}$and $\mathrm{CaLac}_{2}{ }^{0}$ species was detected with formation constants similar to the $\mathrm{CaGluc}^{+}$and $\mathrm{CaGluc}_{2}{ }^{0}$ complexes.

$\alpha-\mathrm{Ket}^{2-}$ and $\beta-\mathrm{Ket}^{2-}$ were shown to form weak calcium complexes with $1: 1$ composition. The stability of $\mathrm{Ca}(\alpha-\operatorname{Ket})^{0}$ was determined to be higher than that of $\mathrm{Ca}(\beta-\mathrm{Ket})^{0}$, which is most probably due to the different structure of the complexes. In $\mathrm{Ca}(\beta-\mathrm{Ket})^{0}$, a six-membered chelate ring is formed, while in $\mathrm{Ca}(\alpha-\mathrm{Ket})^{0}$, a more stable five-membered chelate is present. In both complexes the binding sites of the ligand are suggested to be a carboxylate oxygen and the oxo group.

In alkaline medium both ligands were found to undergo deprotonation. For hydroxycarboxylates, the deprotonation occurred in one of the hydroxy groups resulting in an alcoholate moiety, while in the oxocarboxylates, the deprotonation occurred in a methylene group resulting in the formation of enolate structure.

Comparing Isa ${ }^{-}$with $\mathrm{Gluc}^{-}$, Isa ${ }^{-}$was found to be a weaker acid than $\mathrm{Gluc}^{-}$, its $\mathrm{p} K_{\mathrm{a}}$ was determined to be almost one log-unit larger than that of $\mathrm{Gluc}^{-}$. $\mathrm{Lac}^{-}$was observed to be even weaker acid, the extent of deprotonation reached only $10 \%$ even at $3.5 \mathrm{M} \mathrm{NaOH}$ concentration.

$\beta-\mathrm{Ket}^{2-}$ was determined to be stronger acid than $\alpha-\mathrm{Ket}^{2-}$. The difference in the deprotonation constant of the two ligands can be ascribed to the difference in the structure of the deprotonated species: in $(\beta-\mathrm{Ket}) \mathrm{H}_{-1}{ }^{3-}$ a more extended conjugation is present providing higher stability over $(\alpha-\mathrm{Ket}) \mathrm{H}_{-1}{ }^{3-}$.

In alkaline medium, Isa ${ }^{-}$was found to form only one species, the $\mathrm{CaIsaH}_{-1}{ }^{0}$ complex. In contrast, in the Gluc ${ }^{-}$-containing systems, the formation of the $\mathrm{Ca}_{2} \mathrm{GlucH}_{-3}{ }^{0}$ and $\mathrm{Ca}_{3} \mathrm{Gluc}_{2} \mathrm{H}_{-4}{ }^{0}$ complexes were previously observed beside the $\mathrm{CaGlucH}_{-1}{ }^{0}$ species, moreover, these polynuclear complexes were found to be the prevailing species. Such polynuclear complexes have not been detected in the Isa ${ }^{-}$-containing solutions. It is 
suggested that the prerequisite for the formation of such polynuclear complexes is the possibility of the simultaneous participation of the two hydroxy groups closest to the carboxylate moiety in the metal ion binding. In $\mathrm{Gluc}^{-}$, this condition does hold, while in $\mathrm{Isa}^{-}$, it does not. In this sense, the two ligands are profoundly different, therefore they are not expected to behave identically in strongly alkaline solutions in the presence of calcium and actinides and/or lanthanides, i.e. under the conditions of the low and intermediate level radioactive waste repositories. It can also be expected that the thermodynamics and the structures of the ternary complexes involving $\mathrm{Ca}^{2+}, \mathrm{L}^{-}$and radionuclides depend on whether $\mathrm{L}^{-}=\mathrm{Isa}^{-}$or $\mathrm{Gluc}^{-}$.

The complex formation between $\mathrm{Ca}^{2+}$ and $\mathrm{Lac}^{-}$was investigated in strongly alkaline solutions (i.e., up to $2.6 \mathrm{M} \mathrm{NaOH}$ ), and the formation of the $\mathrm{CaLacH}_{-1}{ }^{0}$ and $\mathrm{CaLacH}_{-2}{ }^{-}$ species was deduced. Since in these strongly alkaline solutions, in the absence of $\mathrm{Lac}^{-}$, calcium is almost exclusively present as $\mathrm{CaOH}^{+}$and $\mathrm{Ca}(\mathrm{OH})_{2}{ }^{0}$, furthermore, the formation constants of $\mathrm{CaLacH}_{-1}{ }^{0}$ and $\mathrm{CaLacH}_{-2}{ }^{-}$are somewhat lower than that of a complex containing a deprotonated hydroxy group (i.e., an $\mathrm{O}^{-}$moiety), these complexes, most probably contain a $\mathrm{Lac}^{-}$ligand coordinated to a $\mathrm{CaOH}^{+}$or a $\mathrm{Ca}(\mathrm{OH})_{2}{ }^{0}$ unit. Therefore, they might be better referred to as $\mathrm{CaLac}(\mathrm{OH})^{0}$ and $\mathrm{CaLac}(\mathrm{OH})_{2}^{-}$.

In alkaline solutions, in the presence of $\mathrm{Ca}^{2+}$ and $\alpha / \beta-\mathrm{Ket}^{2-}$, the formation of complexes with 1:1:-1 composition was observed. The formation constant of $\mathrm{Ca}(\alpha-\mathrm{Ket}) \mathrm{H}_{-1}^{-}$(i.e. for the reaction $\mathrm{Ca}^{2+}+\mathrm{Ket}^{2-} \rightleftharpoons \mathrm{CaKetH}_{-1}^{-}+\mathrm{H}^{+}$) was determined to be lower than that of $\mathrm{Ca}(\beta-\mathrm{Ket}) \mathrm{H}_{-1}{ }^{0}$, which reflects the difference in the deprotonation constants of the ligands. However, the formation constant calculated for the direct association reaction between calcium and the enolate form of the ligands (i.e. $\mathrm{Ca}^{2+}+\mathrm{KetH}_{-1}{ }^{3-} \rightleftharpoons \mathrm{CaKetH}_{-1}{ }^{-}$) is higher for $\alpha-\mathrm{Ket}^{2-}$ supporting the notion that $(\alpha-\mathrm{Ket}) \mathrm{H}_{-1}{ }^{3-}$ is a stronger base than the analogous $\beta$-isomer. Additionally, in the presence of $\alpha-\mathrm{Ket}^{2-}$, the formation of the somewhat unexpected $\mathrm{Ca}_{2}(\alpha-\mathrm{Ket}) \mathrm{H}_{-3}{ }^{-}$species was detected. Since it is unlikely that $(\alpha-\mathrm{Ket}) \mathrm{H}_{-1}{ }^{3-}$ undergoes a second (and a third) deprotonation step, this complex is most probably a calcium hydroxido enolate species, in which an $\mathrm{OH}^{-}$ion is coordinated to each $\mathrm{Ca}^{2+}$ ions. For $\beta-\mathrm{Ket}^{2-}$, the formation of the $\mathrm{Ca}_{2}(\beta-\mathrm{Ket}) \mathrm{H}_{-1}{ }^{+}$complex was observed. In view of these findings, it can be stated that calcium is able to induce the deprotonation of an oxocarboxylate, and subsequently form species in which the ligand contains an enolate functionality. 


\section{7. Összefoglalás}

Munkánk során a radioaktív hulladékelhelyezés szempontjából jelentős hidroxi- és oxokarboxilátok kalciumkomplex-képző sajátságait vizsgáltuk. A kis és közepes aktivitású radioaktív hulladéktárolók erősen lúgos körülményei között jelen levő komplexképző ligandumok jelentős hatással vannak a radioaktív fémionok mobilitására. A hulladéktárolókban legnagyobb mennyiségben megtalálható ligandum az $\alpha$-D-izoszacharinát (Isa ${ }^{-}$), melynek gyakran alkalmazott modellvegyülete a D-glükonát $\left(\mathrm{Gluc}^{-}\right)$, melyet az Isa ${ }^{-}$szerkezeti és funkcionális modelljeként tekintenek. Az ilyen hulladéktárolókban a kalciumion jelentősen nagyobb mennyiségben fordul elő, mint az aktinoidák és lantanoidák, emiatt a kalciumionok jelentősen befolyásolhatják a ligandumok radioaktív fémionokkal való komplexképzését, akár úgy, hogy komplexet képeznek a ligandumokkal, akár úgy, hogy rosszul oldódó csapadék formájában eltávolítják a ligandumokat az oldatfázisból. Mindezek miatt ezen ligandumok kalciumkomplex-képző sajátságainak vizsgálata környezetvédelmi szempontból fontos.

Semleges közegben a vizsgált ligandumok, Isa ${ }^{-}$, laktát $\left(\mathrm{Lac}^{-}\right), \alpha$-ketoglutarát $\left(\alpha-\mathrm{Ket}^{2-}\right)$ és $\beta$-ketoglutarát $\left(\beta-\mathrm{Ket}^{2-}\right)$, kis stabilitású komplexet képeznek $\mathrm{Ca}^{2+}$-ionokkal.

$\mathrm{Az} \mathrm{Isa}^{-}$-t tartalmazó oldatokban $\mathrm{CaIsa}^{+}$komplex képződik, melynek stabilitási állandója a $\mathrm{CaGluc}^{+}$komplexéhez hasonló érték. A Gluc ${ }^{-}$-tartalmú rendszerekben azonban a $\mathrm{CaGluc}^{+}$komplex képződése mellett $\mathrm{Ca}(\mathrm{Gluc})_{2}{ }^{0}$ részecske képződését is kimutatták. Hasonló, 1:2 összetételü komplex az Isa $^{-}$-t tartalmazó oldatokban nem képződött. Ennek a különbségnek az oka feltételezhetően a két ligandum eltérő szerkezetében keresendő. A Gluc -ion flexibilisebb, mint az Isa ${ }^{-}$, emellett a Gluc-ionnal ellentétben az Isa ${ }^{-}$anion tartalmaz egy hidrofób egységet. A $\mathrm{CaIsa}^{+}$és $\mathrm{CaGluc}^{+}$ komplexek szerkezetét kvantumkémiai számolásokkal határoztuk meg. A CaIsa ${ }^{+}$mindkét koordinációs izomerjében az Isa ${ }^{-}$anion háromfogú ligandumként viselkedik, emellett a $\mathrm{Ca}^{2+}$-ionhoz négy vízmolekula koordinálódik, így a koordinációs szám ezeknél a komplexeknél hét. A $\mathrm{CaGluc}^{+}$esetén mindkét koordinációs izomer kétfogú Gluc ${ }^{-}$-ot tartalmaz, így a koordinációs szám a kalciumion körül hat.

A $\mathrm{Ca}^{2+}$-ot, valamint $\mathrm{Isa}^{-}$-t vagy $\mathrm{Gluc}^{-}$-ot tartalmazó semleges oldatokból kinyert egykristályok kristályszerkezetét röntgenkrisztallográfiai mérésekkel határoztuk meg. A CaIsa2 kristályszerkezetét már meghatározták 1968-ban, azonban munkánk során egy szinkrotron sugárforrás alkalmazásával jóval pontosabban meg tudtuk határozni a 
szerkezetet, emellett az OH-csoportok hidrogénatomjainak helyzetét, valamint a hidrogénkötés-rendszert is fel tudtuk térképezni. Mind a CaIsa 2 , mind a $\mathrm{CaGluc}_{2} \cdot 2 \mathrm{H}_{2} \mathrm{O}$ az $a$ tengellyel párhuzamos koordinációs polimerekből álló, nem-centroszimmetrikus, ortorombos szerkezetben kristályosodik. A két szerkezet közötti legjelentősebb különbség az, hogy a CaGluc $2 \cdot 2 \mathrm{H}_{2} \mathrm{O}$-ban az egymás melletti fémcentrumokat $\mu$-oxo hidak kapcsolják össze, míg a CaIsa2-ban az egymás melletti fémcentrumokat két Isa ligandum íveli át. További különbség, hogy míg a CaIsa2-ban a fémion körüli koordinációs szám nyolc, addig a $\mathrm{CaGluc}_{2} \cdot 2 \mathrm{H}_{2} \mathrm{O}$-ban kilenc. A két szerkezetet stabilizáló hidrogénkötés-rendszer is jelentősen eltér.

A $\mathrm{Lac}^{-}$-tartalmú semleges oldatokban $\mathrm{CaLac}^{+}$és $\mathrm{CaLac}_{2}{ }^{0}$ komplexek képződtek, melyek stabilitási állandói hasonlóak a $\mathrm{CaGluc}^{+}$és $\mathrm{CaGluc}_{2}{ }^{0}$ komplexek korábban meghatározott stabilitási állandóihoz.

Az $\alpha$-Ket ${ }^{2-}$-ot és $\beta$-Ket ${ }^{2-}$-ot tartalmazó oldatokban az Isa $^{-}$-hoz hasonlóan kis stabilitású, 1:1 összetételü komplexek képződését tapasztaltuk. A $\mathrm{Ca}(\alpha-\mathrm{Ket})^{0}$ nagyobb stabilitása azzal magyarázható, hogy míg a $\mathrm{Ca}(\beta-\mathrm{Ket})^{0}$ hattagú kelátgyürüt tartalmaz, addig a $\mathrm{Ca}(\alpha-\mathrm{Ket})^{0}$-ban stabilabb öttagú gyürü található. Mindkét komplexben a ligandum feltételezhetően egy karboxilát oxigénen és az oxocsoporton keresztül koordinálódik a $\mathrm{Ca}^{2+}$-ionhoz.

Lúgos közegben a vizsgált ligandumok deprotonálódnak, mely a hidroxikarboxilátok esetén egy alkoholátcsoport kialakulását eredményezi, míg az oxokarboxilátok esetében a deprotonálódás egy metiléncsoporton megy végbe, melynek eredményeképp enolátion jön létre.

$\mathrm{Az}_{\mathrm{Isa}}^{-}$a $\mathrm{Glu}^{-}$-nál gyengébb savnak bizonyult, deprotonálódási állandója a glükonáténál közel egy nagyságrenddel kisebb. $\mathrm{A} \mathrm{Lac}^{-}$az Isa ${ }^{-}$-nál is gyengébb sav, a $\mathrm{Lac}^{-}$ -tartalmú rendszerekben a deprotonálódás mértéke még 3.5 M NaOH-ot tartalmazó oldatban sem éri el a $10 \%$-ot.

A két oxokarboxilát közül $\beta-\mathrm{Ket}^{2-}$ az erősebb sav. A különbség feltehetően a deprotonált ligandumok eltérő szerkezetéből adódik: a $(\beta-\mathrm{Ket}) \mathrm{H}_{-1}{ }^{3-}$ anion esetén kiterjedtebb a konjugáció, ami extra stabilitást eredményez az $(\alpha-\mathrm{Ket}) \mathrm{H}_{-1}{ }^{3-}$-hoz képest.

Lúgos közegben $\mathrm{Ca}^{2+}$-ionok jelenlétében az Isa ${ }^{-}$kizárólag $\mathrm{CaIsaH}_{-1}{ }^{0}$ komplexet képez. Ezzel ellentétben a Gluc-tartalmú oldatokban korábban a hasonló összetételü $\mathrm{CaGlucH}_{-1}{ }^{0}$ mellett $\mathrm{Ca}_{2} \mathrm{GlucH}_{-3}{ }^{0}$ és $\mathrm{Ca}_{3} \mathrm{Gluc}_{2} \mathrm{H}_{-4}{ }^{0}$ összetételü komplexek képződését is kimutatták, sőt, a vizsgált rendszerekben ezek a többmagvú komplexek voltak a domináns részecskék. Ehhez hasonló többmagvú komplexek az Isa ${ }^{-}-\mathrm{t}$ tartalmazó oldatokban nem 
voltak kimutathatók. A többmagvú komplexek kialakulásának feltétele az, hogy a karboxilátcsoport melletti két hidroxilcsoport egyaránt részt tudjon venni a fémion megkötésében, azaz az egyik $\mathrm{OH}$-csoport az egyik $\mathrm{Ca}^{2+}$-ionhoz koordinálódik, míg a másik OH-csoport a másik fémionhoz. Ez a feltétel a $\mathrm{Gluc}^{-}$esetében teljesül, míg az Isa ${ }^{-}$ esetében nem. Ebből a szempontból a két ligandum viselkedése jelentősen eltér egymástól, ezért feltételezhetően az Isa $^{-}$nem fog a Gluc ${ }^{-}$-tal megegyező módon viselkedni erösen lúgos, kalciumionokat és aktinoidákat/lantanoidákat tartalmazó oldatokban (tehát a kis és közepes aktivitású hulladéklerakókban uralkodó körülmények között). Várhatóan a $\mathrm{Ca}^{2+}$-ot, $\mathrm{L}^{-}$-ot és egy radioaktív fémiont tartalmazó terner rendszerek stabilitása és szerkezete függ attól, hogy $\mathrm{L}^{-}=\mathrm{Isa}^{-}$vagy Gluc $^{-}$.

A $\mathrm{Ca}^{2+}-\mathrm{Lac}^{-}$-rendszer erősen lúgos közegbeli viselkedését $0.2-2.6 \mathrm{M} \mathrm{NaOH}$-ot tartalmazó oldatokban vizsgáltuk. A vizsgált rendszerekben $\mathrm{CaLacH}_{-1}{ }^{0}$ és $\mathrm{CaLacH}_{-2}{ }^{-}$ komplexek képződését mutattuk ki. Ilyen erősen lúgos oldatokban Lac ${ }^{-}$-ionok jelenléte nélkül a kalciumionok gyakorlatilag teljes mértékben $\mathrm{CaOH}^{+}$és $\mathrm{Ca}(\mathrm{OH})_{2}{ }^{0}$ hidroxokomplexek formájában vannak jelen. Továbbá a $\mathrm{CaLacH}_{-1}{ }^{0}$ és $\mathrm{CaLacH}_{-2}{ }^{-}$ komplexek stabilitási állandói alacsonyabb értékek egy olyan komplex stabilitási állandójánál, mely deprotonált hidroxilcsoportot (azaz $\mathrm{O}^{-}$funkciós csoportot) tartalmaz. Mindezek miatt feltehetően a fenti két komplexben egy Lac ${ }^{-}$ligandum koordinálódik egy $\mathrm{CaOH}^{+}$vagy egy $\mathrm{Ca}(\mathrm{OH})_{2}{ }^{0}$ részecskéhez, így szemléletesebb $\mathrm{CaLac}(\mathrm{OH})^{0}$ és $\mathrm{CaLac}(\mathrm{OH})_{2}{ }^{-}$részecskékként jelölni őket.

Lúgos közegben $\mathrm{Ca}^{2+}$-ionok és $\alpha / \beta-\mathrm{Ket}^{2-}$-ionok jelenlétében 1:1:-1 összetételü komplexek képződését tapasztaltuk. A $\mathrm{Ca}^{2+}$-ionok és $(\alpha / \beta-\mathrm{Ket}) \mathrm{H}_{-1}{ }^{3-}$-ionok közötti direkt asszociációs reakcióban képződő $\mathrm{Ca}(\alpha / \beta-\mathrm{Ket}) \mathrm{H}_{-1}{ }^{-}$komplex stabilitási állandója az $\alpha$-izomer esetében nagyobb az $\alpha-\mathrm{Ket}^{2-}$ nagyobb bázicitása miatt. Az $\alpha-\mathrm{Ket}^{2-}$-ionokat tartalmazó oldatokban a fenti mellett egy $\mathrm{Ca}_{2}(\alpha-\mathrm{Ket}) \mathrm{H}_{-3}{ }^{-}$összetételü részecske is képződik. Mivel az $(\alpha-K e t) H_{-1}{ }^{3-}$-ion nem képes még két deprotonálódási lépésre, ez a komplex feltehetően egy kalcium-hidroxido-enolát komplex, melyben mindkét $\mathrm{Ca}^{2+}$-ionhoz koordinálódik egy $\mathrm{OH}^{-}$-ion. $\beta$-Ket ${ }^{2-}$ jelenlétében az 1:1:-1 komplex mellett egy $\mathrm{Ca}_{2}(\beta-\mathrm{Ket}) \mathrm{H}_{-1}{ }^{+}$részecske képződését is valószínüsítettük. Mindezek ismeretében kijelenthető, hogy a kalciumion képes indukálni egy oxokarboxilát deprotonálódását, melynek során egy olyan komplex képződik, melyben a ligandum egy enolát funkciós csoportot tartalmaz. 


\section{References}

1. D.L. Nelson, M.M. Cox, Lehninger, Principles of Biochemistry, Worth Publishing: New York, 2000, $3^{\text {rd }}$ edition

2. D. Rai, L. Rao, Y. Xia, J. Solution Chem. 27 (1998) 1109-1122.

3. J. Hagberg, A. Düker, S. Karlsson, Chromatographia 56 (2002) 641-644.

4. H. Cho, D. Rai, N.J. Hess, Y. Xia, L. Rao, J. Solution Chem. 32 (2003) 691-702.

5. $\quad$ D. Rai, A. Kitamura, J. Nucl. Sci. Technol. 53 (2016) 459-467.

6. P.L. Brown, S. Allard, C. Ekberg, J. Chem. Eng. Data 55 (2010) 5207-5213.

7. S. Motellier, C. Richet, P. Merel, J. Chromagogr. A 804 (1998) 363-370.

8. $\quad$ S. Motellier, Y. Charles, Anal. Chim. Acta 375 (1998) 243-254

9. J. Hagberg, Metal complexing abilities of products obtained from alkaline degradation of cellulose: Complexation of isosaccharinic acid with copper, Thesis, diploma work, Number 970606, Linköping University, Sweden, (1997).

10. S. Ekberg, C. Ekberg, Y. Albinsson, Mater. Res. Soc. Symp. Proc. 757 (2003) 503508.

11. L. Rao, A.Y. Garnov, D. Rai, Y. Xia, R.C. Moore, Radiochim. Acta 92 (2004) 575581.

12. R.M. de Lederkremer, C. Marino, Adv. Carbohyd. Chem. Bi. 58 (2003) 199-306.

13. D. Rai, N.J. Hess, Y. Xia, L. Rao, H.M. Cho, R.C: Moore, L.R. Van Loon, J. Solution Chem. 32 (2003) 665-675.

14. W. Hummel, G. Anderegg, L. Rao, I. Puigdomènech, O. Tochiyama, Chemical thermodynamics of compounds and complexes of $\mathrm{U}, \mathrm{Np}, \mathrm{Pu}, \mathrm{Am}, \mathrm{Tc}$. Se, Ni and $\mathrm{Zr}$ with selected organic ligands. Chemical thermodynamics, Elsevier: Amsterdam, 2005, Vol. 9.

15. M. Vavrusova, M. B. Munk, L. H. Skibsted, J. Agr. Food. Chem. 61 (2013) 82078214.

16. N. Kubantseva, R. W. Hartel, Food. Rev. Int. 18 (2002) 135-149.

17. C. Phadungath, L. E. Metzger, J. Dairy Sci. 94 (2011) 4843-4849.

18. P. Rajbhandari, J. Patel, E. Valentine, P. S. Kindstedt, J. Dairy Sci. 96 (2013) 34423448 .

19. Y. Sakata, S. Shiraishi, M. Otsuka, Colloid. Surface. B 46 (2005) 135-141.

20. A.W. Martin, H.V. Tartar J. Am. Chem. Soc. 59 (1937) 2672-2675.

21. M. Hlaibi, S. Chapelle, M. Benaissa, J.F. Verchère, Inorg. Chem. 34 (1995) 44344440

22. S. Glab, M. Maj-Zurawska, P. Lukomski, A. Hulanicki, Anal. Chim. Acta 273 (1993) 493-497.

23. R.K. Cannan, A. Kibrick, J. Am. Chem. Soc. 60 (1938) 2314-2320.

24. J. Piispanen, L.H.J. Lajunen, Acta Chem. Scand. 49 (1995) 235-240. 
25. E. Marklund, S. Sjöberg, L-O. Öhman, Acta Chem. Scand. A 40 (1986) 367-373.

26. E. Bottari, R. Jasionowska, Ann. Chim. (Rome) 69 (1974) 277.

27. K.M. Jones, E. Larsen, Acta Chem. Scand. 19 (1965) 1205-1209.

28. A. Dadgar, G.R. Choppin J. Inorg. Nucl. Chem. 34 (1972) 1297-1301.

29. J.J. Cruywagen, L. Kruger, E.A. Rohwer, J. Chem. Soc. Dalton Trans. (1993) 105109.

30. R. Portanova, L.H.J. Lajunen, M. Tolazzi, J. Piispanen, Pure Appl. Chem. 75 (2003) 495-540.

31. J.L. Espartero, I. Rashkov, S.M. Li, N. Manolova, M. Vert, Macromolecules 29 (1996) 3535-3539.

32. M. Ajoika, K. Enomoto, K. Suzuki, A. Yamaguchi, Bull. Chem. Soc. Jpn. 68 (1995) 2125-2131.

33. G.L. Siparsky, K.J. Voorhees, F. Miao, J. Environ. Polym. Degr. 6 (1998) 31-41.

34. T.S. Viswanathan, R.E. Johnson, H.F. Fischerm, Biochemistry 21 (1982) 339-345.

35. I.G. Morgunov, S.V. Kamzolova, V.A. Samolienko, Appl. Microbiol. Biot. 97 (2013) 8711-8718.

36. S.V. Kamzolova, M.N. Chiglintseva, J.N. Lunina, I.G. Morgunov, Appl. Microbiol. Biot. 96 (2012) 783-791.

37. J.T. Smith, V.N. Doctor, Inorg. Nucl. Chem. 37 (1975) 775-777.

38. H. Scheidegger, W. Felty, D.L. Leussing, J. Am. Chem. Soc. 92 (1970) 808-810.

39. A.J. Cooper, A.G. Redfield, J. Biol. Chem. 250 (1975) 527-532.

40. A.J.L. Cooper, J.Z. Ginos, A. Meister, Chem. Rev. 83 (1983) 321-358.

41. J. Sporar, J. Bezensek, U. Ursic, A. Golobic, J. Svete, B. Stanovnik, Heterocycles 84 (2012) 449-459.

42. J. Svetlik, L. Veizerova, V. Kettmann, Tertahedron Lett. 49 (2008) 3520-3523.

43. S.K. Ghosh, M. Nazimuddin, B.M. Mandal, Macromol. Chem.-Rapid 13 (1992) 583-586.

44. Y. Wang, A.T. Stone, Geochim. Cosmochim. Ac. 70 (2006) 4463-4476.

45. J. Clayden, N. Greeves, S. Warren, P. Wothers, Organic Chemistry, Oxford University Press, New York, NY, U.S., 2001, pp. 192-196.

46. D.D. Perrin, B. Dempsey, E.P. Serjeant, $p K a$ Prediction for Organic Acids and Bases, London, UK; Chapman and Hall, New York, NY, U.S., 1981, p. 28.

47. A. Pallagi, É.G. Bajnóczi, S.E. Canton, T. Bolin, G. Peintler, B. Kutus, Z. Kele, I. Pálinkó, P. Sipos, Environ. Sci. Technol. 48 (2014) 6604-6611.

48. J. Kozlowski, P. Zuman, Bioelectroch. Bioener. 28 (1992) 43-70.

49. B. Gyurcsik, L. Nagy, Coord. Chem. Rev. 203 (2000) 81-149.

50. L.R. Van Loon, M.A. Glaus, K. Vercammen, J. Solution Chem. 33 (2004) 15731583.

51. R. Gosh, V. S. K. Nair, J. Inorg. Nucl. Chem. 32 (1970) 3025-3032. 
52. J. Schubert, A. Lindenbaum, J. Am. Chem. Soc. 74 (1952) 3529-3532.

53. F. Verbeek, H. Thun, Anal. Chim. Acta 33 (1965) 378-383.

54. M. Masone, M. Vicedomini, Ann. Chim. Rome 71 (1981) 517.

55. A. Kondoh, T. Oi, Z. Naturforsch Sect. A - J. Physy. Sci. 52a (1997) 351-357.

56. C.W. Davies, J. Chem. Soc. (1938) 277-281.

57. A.P.G. Kieboom, H.M.A. Buurmans, L.K. van Leeuwen, H.J. van Benschop, Recl. Trav. Chim. Pays-Bas 98 (1979) 393-394.

58. L. Lepri, P.G. Desideri, J. Chromatogr. 84 (1973) 155.

59. N. Buzás, T. Gajda, L. Nagy, E. Kuzmann, A. Vértes, K. Burger, Inorg. Chim. Acta 274 (1998) 167-176.

60. K. Vercammen, M. Glaus, L. Van Loon Acta Chem. Scand. 53 (1999) 241-246.

61. K. Vercammen, Complexation of Calcium, Thorium and Europium by $\alpha$ Isosaccharinic Acid under Alkaline Conditions, Ph.D. dissertation, Swiss Federal Institute of Technology, Zurich, 2000.

62. B. Kutus, Cs. Dudás, G. Peintler, I. Pálinkó, P. Sipos, Carbohyd. Res. 460 (2018) 36-40.

63. A. Pallagi, Z. Csendes, B. Kutus, E. Czeglédi, G. Peintler, P. Forgó, I. Pálinkó, P. Sipos, Dalton Trans. 42 (2013) 8460-8467.

64. U.R. Berner, Waste Manage. 12 (1992) 201-219.

65. U. Berner, A Thermodynamic Description of the Evolution of Pore Water Chemistry and Uranium Speciation During the Degradation of Cement, PSI Bericht 62, Paul Scherrer Institut, Villigen, Switzerland, 1990.

66. V. Neck, M. Altmaier, T. Rabung, J. Lutzenkirchen, T. Fanghänel, Pure Appl. Chem. 81 (2009) 1555-1568.

67. C. Bube, V. Metz, E. Bohnert, K. Garbev, D. Schild, B. Kienzler, Phys. Chem. Earth 64 (2013) 87-94.

68. B. Kienzler, V. Metz, B. Brendebach, N. Finck, M. Plaschke, Th. Rabung, J. Rothe, D. Schild, Radiochim. Acta 98 (2010) 675-684.

69. J. Tits, E. Wieland, M.H. Bradbury, P. Eckert, A. Schaible, The Uptake of Eu(III) and Th(IV) by Calcite Under Hyperalkaline Conditions, PSI Bericht 02-03., Paul Scherrer Institut, Villigen, Switzerland, 2002

70. E. Wieland, L.R. Van Loon, Cementitious Near-Field Sorption Data Base for Performance Assessment of an ILW Repository in Opalinus Clay, PSI Bericht 0306., Paul Scherrer Institut, Villigen, Switzerland, 2003

71. X. Gaona, D. Fellhauer, M. Altmaier, Pure Appl. Chem. 85 (2013) 2027-2049.

72. U.R. Berner, Cement Concrete Res. 22 (1992) 465-475.

73. J.F. Lucchini, M. Borkowski, M.K. Richmann, S. Ballard, D.T. Reed, J. Alloy. Compd., 444-445 (2007) 506-511.

74. M. Borkowski, J.F. Lucchini, M. Richmann, D.T. Reed, Actinide(III) solubility in WIPP brine: data summary and recommendations, Los Alamos National Laboratory, Los Alamos, USA, 2009. 
75. B. Brendebach, M. Altmaier, J. Rothe, V. Neck, M.A. Denecke, Inorg. Chem. 46 (2007) 6804-6810.

76. M. Altmaier, V. Neck, T. Fanghänel, Radiochim. Acta 96 (2008) 541-550.

77. D. Fellhauer, V. Neck, M. Altmaier, J. Lützenkirchen, T. Fanghänel, Radiochim. Acta 98 (2010) 541-548.

78. M. Altmaier, X. Gaona, T. Fanghänel, Chem. Rev. 113 (2013) 901-943.

79. D. Fellhauer, J. Rothe, M. Altmaier, V. Neck, J. Runke, T. Wiss, T. Fanghänel, Radiochim. Acta 104 (2016) 355-379.

80. D. Fellhauer, M. Altmaier, X. Gaona, J. Lützenkirchen, T. Fanghänel, Radiochim. Acta 104 (2016) 381-397.

81. M. Herm, X. Gaona, T. Rabung, D. Fellhauer, C. Crepin, K. Dardenne, M. Altmaier, H. Geckeis, Pure Appl. Chem. 87 (2015) 487-502.

82. J.A. Berry, K.A. Bond, D.R: Ferguson, N.J. Pilkington, Radiochim. Acta 52-53 (1991) 201-209.

83. G.M.N. Baston, J.A. Berry, K.A. Bond, M. Brownsword, C.M. Linklater, Radiochim. Acta 58-59 (1992) 349-356.

84. G.M.N. Baston, J.A. Berry, K.A. Bond, K.A. Boult, M. Brownsword, C.M. Linklater, J. Alloy. Compd. 213 (1994) 475-480.

85. L.R. Van Loon, M.A. Glaus, S. Stallone, A. Laube, Environ. Sci. Technol. 31 (1997) 1243-1245.

86. G. Richards, H. Sephton, J. Am. Chem. Soc. (1957) 4492-4499.

87. G. Machell, G. Richards, J. Am. Chem. Soc. (1957) 4500-4506.

88. M.A. Glaus, L.R. Van Loon, Environ. Sci. Technol. 42 (2008) 2906-2911.

89. R.L. Whistler, J.N. BeMiller, Adv. Carbohyd. Chem. 13 (1958) 289-329.

90. R.L. Whistler, J.N. BeMiller, J. Am. Chem. Soc. 82 (1960) 3705-3707.

91. L.Å. Lindström, O. Samuelson, Acta Chem. Scand. 31b (1977) 479-484.

92. M.A. Glaus, L.R. Van Loon, S. Achatz, A. Chodura, K. Fischer, Anal. Chim. Acta 398 (1999) 111-122.

93. G. Machell, G.N. Richards, J. Am. Chem. Soc. (1960) 1932-1938.

94. C.J. Knill, J.F. Kennedy, Carbohyd. Polym. 51 (2003) 281-300.

95. M. Almond, D. Belton, P.N. Humphreys, A.P. Laws, Carbohyd. Res. 427 (2016) $48-54$.

96. L.R. Van Loon, M.A. Glaus, Experimental and Theoretical Studies on Alkaline Degradation of Cellulose and its Impact on the Sorption of Radionuclides, PSI Bericht 98-07, Paul Scherrer Institut, Villingen, Switzerland, 1998

97. I. Pavasars, J. Hagberg, H. Borén, B. Allard, J. Polym. Environ. 11 (2003) 39-47.

98. S. Ramachandran, P. Fontanille, A. Pandey, C. Larroche, Food Technol. Biotechnol. 44 (2006) 185-195.

99. M. A. Glaus, A. Laube, L. R. Van Loon, Waste Manag. 26 (2006) 741-751. 
100. S. Ma, W. Li, S. Zhang, D. Ge, J. Yu, X. Shen, Constr. Build. Mater. 91 (2015) 138-144.

101. X. Gaona, V. Montoya, E. Colàs, M. Grivé, L. Duro, J. Contam. Hydrol. 102 (2008) 217-227.

102. Z. Zhang, B. Bottenus, S. B. Clark, G. X. Tian, P. Zanonato, L. F. Rao, J. Alloy Compd. 444 (2007) 470-476.

103. Z. Zhang, G. Helms, S. B. Clark, G. X. Tian, P. Zanonato, L. F. Rao, Inorg. Chem. 48 (2009) 3814-3824.

104. S. Giroux, P. Rubini, B. Henry, S. Aury, Polyhedron 19 (2000) 1567-1574.

105. S. Giroux, S. Aury, B. Henry, P. Rubini, Eur. J. Inorg. Chem. (2002) 1162-1168.

106. J. Tits, E. Wieland, M. H. Bradbury, Appl. Geochem. 20 (2005) 2082-2096.

107. E. Colàs, M. Grivé, I. Rojo, J. Solution Chem. 42 (2013) 1545-1557.

108. E. Colàs, M. Grivé, I. Rojo, L. Duro, J. Solution Chem. 42 (2013) 1680-1690.

109. H. Rojo, J. Tits, X. Gaona, M. Garcia-Gutierrez, T. Missana and E. Wieland, Radiochim. Acta 101 (2013) 133-138.

110. K.H. Birjkumar, N.D. Bryan, N. Kaltsoyannis, Dalton Trans. 41 (2012) 5542-5552.

111. S. Allard, C. Ekberg, Radiochim. Acta 94 (2006) 537-540.

112. S. Allard, C. Ekberg, J. Solution. Chem. 35 (2006) 1173-1186.

113. V. Diesen, K. Forsberg, M. Jonsson, J. Hazard Mater. 340 (2017) 384-389.

114. M.J. Keith-Roach, Sci. Total. Environ. 396 (2008) 1-11.

115. N. Evans, P. Warwick, M. Felipe-Sotelo, S. Vines, J. Radioanal. Nucl. Chem. 293 (2012) 725-730.

116. T. Kobayashi, T. Teshima, T. Sasaki, A. Kitamura, J. Nucl. Sci. Technol. 54 (2017) 233-241.

117. D. Rai, M. Yui, D.A. Moore, L. Rao, J. Solution Chem. 38 (2009) 1573-1587.

118. I. Pointeau, D. Hainos, N. Coreau, P. Reiller, Waste Manage. 26 (2006) 733-740.

119. P. Warwick, N. Evans, S. Vines, Radiochim. Acta 94 (2006) 363-368.

120. P. Warwick, N. Evans, T. Hall, S. Vines, Radiochim. Acta 92 (2004) 897-902.

121. D. Rai, L. Rao, D.A. Moore, Radiochim. Acta 83 (1998) 9-13.

122. A.D. Moreton, Mater. Res. Soc. Symp. Proc. 294 (1993) 753-758.

123. B.F. Greenfield, C.M. Linklater, A.D. Moreton, M.W. Spindler, S.J. Williams, in: Actinide Processing: Methods and Materials, B. Mishra, Ed., Minerals, Metals and Materials Society, Warrendale, PA, U.S., 1994, pp 289-303.

124. A.R. Felmy, Chemical Speciation of Americium, Curium and Selected Tetravalent Actinides in High Level Waste, PNNL, EMSP Project 73749, USA, 2004.

125. E. Colàs, M. Grivé, I. Rojo, L. Duro, Radiochim. Acta, 99 (2011) 269-273.

126. P.B. Shaw, G.F. Robinson, C.R. Rice, P.N. Humphreys, A.P. Laws, Carbohyd. Res. 349 (2012) 6-11. 
127. H. Deelstra, F. Verbeek, Anal. Chim. Acta 31 (1964) 251-257.

128. L.E. Roy, L.R. Martin, Dalton Trans. 45 (2016) 15517-15522.

129. A. Barkleit, J. Kretzschmar, S. Tsushima, M. Acker, Dalton Trans. 43 (2014) 11221-11232.

130. G. Tian, L.R. Martin, L. Rao, Inorg. Chem. 49 (2010) 10598-10605.

131. L.R. Van Loon, M.A. Glaus, K. Vercammen, Acta Chem. Scand. 53 (1999) 235240.

132. K. Vercammen, M.A. Glaus, L.R. Van Loon, Radiochim. Acta 89 (2001) 393-401.

133. A. Tasi, X. Gaona, D. Fellhauer, M. Böttle, J. Rothe, K. Dardenne, R. Polly, M. Grivé, E. Colàs, J. Bruno, K. Källstrom, M. Altmaier, H. Geckeis, Appl. Geochem. accepted manuscript, DOI: 10.1016/j.apgeochem.2018.06.014

134. A. Tasi, Solubility, redox and sorption behavior of plutonium in the presence of $\alpha$ $D$-isosaccharinic acid and cement under reducing conditions, Ph.D. dissertation, Karlsruher Instituts für Technologie (KIT), Karlsruhe, 2018

135. M. Svensson, M. Berg, K. Ifwer, R. Sjöblom, H. Ecke, J. Hazard. Mater. 144 (2007) 477-484.

136. P. Sipos, P. M. May, G. Hefter, Analyst 125 (2000) 955-958.

137. R. L. Whistler, J. N. BeMiller, In: Wolfrom, M. L.; BeMiller, J. N. Eds., Methods in carbohydrate chemistry, Academic Press, New York, 1963, Vol. 2: Reactions of Carbohydrates, pp. 477-479.

138. G. Peintler, Spline Calculuc, Version 2.12a, University of Szeged, Szeged, Hungary, 2008.

139. I. Kron, S. L. Marshall, P. M. May, G. Hefter, E. Königsberger, Monatsh. Chem. 126 (1995) 819-837.

140. L. Zékány, I. Nagypál, G. Peintler, PSEQUAD for Chemical Equilibria, Update 55.10, Hungary, 2000-2008.

141. Gaussian 09, Revision A.02-E.01, Gaussian, Inc., Wallingford, CT, U.S., 2013.

142. A. D. Becke, Phys. Rev. A. 38 (1988) 3098-3100.

143. C. Lee, W. Yang, R. G. Parr, Phys. Rev. B. 37 (1988) 785-789.

144. J. Tomasi, B. Mennucci, R. Cammi, Chem. Rev. 105 (2005) 2999-3093.

145. L. Farrugia, J. Appl. Crystallogr. 32 (1999) 837-838.

146. L. J. Farrugia, J. Appl. Crystallogr. 45 (2012) 849-854.

147. C. B. Hübschle, G. M. Sheldrick, B. Dittrich, J. Appl. Crystallogr. 44 (2011) 12811284.

148. O. V. Dolomanov, L. J. Bourhis, R. J. Gildea, J. A. K. Howard, H. Puschmann, J. Appl. Crystallogr. 42 (2009) 339-341.

149. K. Momma, F. Izumi, J. Appl. Crystallogr. 44 (2011) 1272-1276.

150. S. R. Hall, D. J. du Boulay, R. Olthof-Hazekamp, Xtal3.7 University of Western Australia, 2000

151. G. M. Sheldrick, Acta Crystallogr. Sect. Found. Adv. 71 (2015) 3-8. 
152. G. M. Sheldrick, Acta Crystallogr. Sect. C Struct. Chem. 71 (2015) 3-8.

153. G. M: Sheldrick, Acta Crystallogr. A. 64 (2008) 112-122.

154. S. J. Coles, P. A. Gale, Chem Sci. 3 (2012) 683-689.

155. S. Parsons, H. D. Flack, T. Wagner, Acta Crystallogr. Sect. B Struct. Sci. Cryst. Eng. Mater. 69 (2013) 249-259.

156. H. D. Flack, Chim. Int. J. Chem. 68 (2014) 26-30.

157. S. Brockhauser, R. B. G. Ravelli, A. A. McCarthy, Acta Crystallogr. D Biol. Crystallogr. 69 (2013) 1241-1251.

158. A. Burkhardt, T. Pakendorf, B. Reime, J. Meyer, P. Fischer, N. Stübe, S. Panneerselvam, O. Lorbeer, K. Stachnik, M. Warmer, P. Rödig, D. Göries, A. Meents, Eur. Phys. J. Plus. 131 (2016) 1-9.

159. J. Gabadinho, A. Beteva, M. Guijarro, V. Rey-Bakaikoa, D. Spruce, M. W. Bowler, S. Brockhauser, D. Flot, E. J. Gordon, D. R. Hall, B. Lavault, A. A. McCarthy, J. McCarthy, E. Mitchell, S. Monaco, C. Mueller-Dieckmann, D. Nurizzo, R. B. G. Ravelli, X. Thibault, M. A. Walsh, G. A. Leonard, S. M. McSweeney, S. M. J. Synchrotron Radiat. 17 (2010) 700-707.

160. W. Kabsch, Acta Crystallogr. D Biol. Crystallogr. 66 (2010) 125-132.

161. R. Norrestam, P.E. Werner, M. Von Glehn, Acta Chem. Scand. 22 (1968) 13951403.

162. B. Kutus, D. Ozsvár, N. Varga, I. Pálinkó, P. Sipos Dalton Trans. 46 (2017) 10651074.

163. A. Pallagi, P. Sebők, P. Forgó, T. Jakusch, I. Pálinkó, P. Sipos, Carbohydr. Res. 345 (2010) 1856-1864.

164. H.A. Tajmir-Riahi J. Inorg. Biochem. 39 (1990) 33-41.

165. I. Kron, S. L. Marshall, P. M. May, G. Hefter, E. Königsberger, Monatsh. Chem. 126 (1995) 819-837.

166. B. Kutus, A. Gácsi, A. Pallagi, I. Pálinkó, G. Peintler, P. Sipos, RSC Adv. 6 (2016) $45231-45240$.

167. Á. Buckó, B. Kutus, G. Peintler, I. Pálinkó, P. Sipos, Polyhedron, accepted manuscript

168. P. Ballinger, F.A. Long, J. Am. Chem. Soc. 82 (1960) 795-798.

169. OriginPro, Version 8.6, OriginLab, Northhampton, MA, U.S., 2011

170. L. Cattalini, A. Cassol, G. Marangoni, G. Rizzardi, E. Rotondo, Inorg. Chim. Acta 3 (1969) 681-684.

171. G.J. McDougall, R.D. Hancock, J. Chem. Soc., Dalton Trans. (1978) 1438-1444.

172. J. Schoubroeck, A.M. Goeminne, Z. Anorg. Allg. Chem. 492 (1982) 188-196.

173. V.A. Kogan, S.G. Kochin, A.S. Antsyshkina, G.G. Sadikov, A.D. Garnovskii, Mendeleev Commun. 7 (1997) 239-240.

174. Y. Chiang, A.J. Kresge, P. Pruszynski, J. Am. Chem. Soc. 114 (1992) 3103-3107. 


\section{Acknowledgement}

First of all, I would like to express my immense gratitude for my supervisors, Prof. Dr. Pál Sipos and Prof. Dr. István Pálinkó for giving me an opportunity to work in the Material and Solution Structure Research Group (MASOST), for guiding me through my work and giving me continuous support during my research.

I would like to thank Dr. Gábor Peintler for helping me with the data evaluation, for teaching me the tiny little details of the PSEQUAD program and for always being patient.

I am highly grateful for Dr. Valéria Bugris and Prof. Peter Turner for giving me immense help with regard to the single crystal experiments.

I would like to thank Bence Kutus for always helping me with any problem, for giving me essential suggestions and for being a friend.

My sincere thanks goes to every member of the MASOST family for creating such a cheerful atmosphere where I loved to work. I am sincerely grateful for Ilona Halasiné Varga for making my labwork a lot easier.

Words cannot express how grateful I am for the tremendous support of my family: my parents, Lajos Dudás and Marianna Dudásné Nagy, my son, Marci Hancsák, my fiancé, Dr. Gábor Varga, and my brother, Zsolt Dudás. Their emotional support in the hard times meant everything to me. 